\title{
PhD 16809
}

University of Cambridge

Faculty of History

\section{THE TEXT AND CONTEXT}

\section{OF THE}

\section{MALLEUS MALEFICARUM (1487)}

Eric Wilson

Clare College

A Dissertation Submitted

for the Degree of

Doctor of Philosophy 
CONTENTS.

ABSTRACT

PREFACE

ACKNOWLEDGEMENTS iv

INTRODUCTION

CHAPTER ONE: THE PLACE OF THE TEXT 20

CHAPTER TWO: $\quad$ AUTHOR(S) AND TEXT(S) 66

II. 1. Heinrich Kramer (Institoris) 67

II. 2. Jacob Sprenger 108

II. 3. Authorial Identity within the Malleus 122

II. 4. The Composition and Publication of the Malleus: Time and Place 131

II. 5. The Summis Desiderantes Affectibus 136

II. 6. The Notary Instrument of 19 May 1487
and the University of Cologne

CHAPTER THREE: INSTITORIS AS INQUISITOR 169

III. 1. Institoris in the Field 176

III. 2. Ravensburg and Innsbruck 207

CHAPTER FOUR: THE MALLEUS, "HEXENGLAUBE", AND WOMEN AS WITCHES 239

CHAPTER FIVE: $\quad$ THEOLOGICAL SOURCES AND TEXTS 279

CHAPTER SIX: $\quad$ SUPERSTITION, SCEPTICISM, AND THE CANON EPISCOPI 304

CHAPTER SEVEN: INQUISITORIAL TEXTS AND THE SABBAT 354

$\begin{array}{ll}\text { CONCLUSION } & 399\end{array}$ 
APPENDICES:

A. The "Apologia Auctoris" of the Malleus 403

B. Letter of 17 December 1484 from the Mayor of Ravensburg to Archduke Sigismund 407

C. Promulgation of the Summis desiderantes affectibus of Innocent VIII by Bishop Georg Golser of Brixen, 23 July 1484

D. The Canon Episcopi

E. The Publishing History of the Malleus 


\begin{abstract}
.
My dissertation is a study of both the historical background to and the literary content of the Malleus Maleficarum of Heinrich Institoris and Jakob Sprenger, the archetypal witch-hunting manual of the late middle ages. I interpret the text as engaging in a highly specialized form of cultural semiotics, fabricating a category of social deviant - the witch - through the employment of discursive practices common to theological and inquisitorial literature. In this way the figure of the witch was rendered subject to the same forms of litrary representation and political control as were a number of other marginalized social and religious minorities, including the heretic, the leper, and the Jew.
\end{abstract}

Chapter One situates the Malleus within the historical context of the development of demonological literature and the socio-cultural stereotypes of the diabolic subversive, the text acting as the culmination of these trends at the end of the fifteenth century. Chapter Two discusses the lives and careers of the two reputed authors of the text, examining their activities in relation to developments in late medieval inquisitorial jurisprudence and curial politics. Chapters Three and Four highlight the witch-hunting activities of Institoris in southern Germany and Austria, and the text's resulting (mis)representation of popular notions of the witch and of witchcraft. Chapters Five to Seven 
examine a number of crucial literary traditions and practices utilized in the Malleus in achieving the transformation of the village "wise woman" into the diabolic heretic of formal theological speculation. Topics discussed include the teachings of Augustine and Aquinas on superstition and demonic causal agency, the Canon Episcopi and learned scepticism about the reality of maleficium, and the evolution of the concept of the Sabbat in fourteenth- and fifteenth-century inquisitorial writing. Central to all chapters is an emphasis upon the way in which the Malleus can be regarded as an active point of interface between popular and learned cultural perceptions. 


\section{PREFACE.}

In accordance with the Board of Graduate Studies' regulations for the $\mathrm{Ph} . \mathrm{D}$. Degree in History, I declare that this thesis is the result of my own original work. The sources from which any information is derived are specified in the footnotes and in the Bibliography. I certify furthermore that my dissertation does not exceed 80,000 words, excluding footnotes and Bibliography.

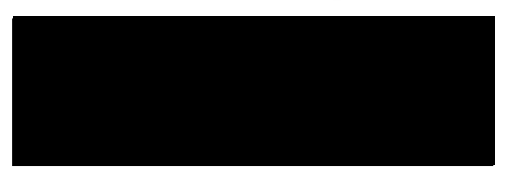

Eric Wilson.

Cambridge, December 1990 


\section{ACKNOWLEDGEMENTS.}

A work of this size, written over the course of several years, undeniably owes much to many people. I can mention only a few of them here. I would like to thank the Social Sciences and Humanities Research Council of Canada, which provided me with the single largest source of financial support for the greater part of my time in Cambridge - without their assistance, I would have lacked the funds necessary for the completion of this thesis. Similar thanks are due to the Commonwealth Bursary as well as to the Overseas Research Scheme for additional support. A special thank you is forthcoming to the German Historical Institute, which subsidized my year of research at the Staatsbibliothek and Staatsarchiv in Munich.

On a more personal level, I would like to thank my supervisor, Dr. Robert Scribner of Clare College, for displaying the necessary mixture of discipline, patience, and sense of direction vital to this sort of project. Other people who have contributed, either directly or indirectly to my work are too numerous to be mentioned here. I would, however, like to express special gratitude to those whose assistance proved most vital - Dr. Richard Tuck, Mr. Maurice Biriotti, Dr. Andreas Blauert, Dr. Wolfgang Behringer, Dr. Heide Dienst, and Dr. Julia Crick.

My highest appreciation, however, goes to my wife Eva-Maria, to whom this dissertation is dedicated. Her unswerving sense of commitment, dedication, and basic common-sense helped me get through many a "dark night of the soul". Without her support this work would not have come to be - it also wouldn't have been formatted so nicely, either. 


\section{INTRODUCTION.}

It is difficult to situate the Malleus Maleficarum within any specific historiographical tradition, as it is a text far more often referred to than actually analyzed. ${ }^{1}$ Although virtually every academic work on witchcraft persecutions published since W.G. Soldan's ground-breaking Hexenprozesse of 1843 utilizes the Malleus in some fashion, no scholar has ever essayed a fulllength study of the text, one which would strive to come to direct terms with either its formal structure as a literary work or its ideological content as a theological treatise. Neither J.W.R. Schmidt's 1906 German translation nor Montague Summers' notorious 1928 English rendition provided the form of critical analysis which the length and the historical importance of the Malleus would seem to warrant. The most recent direct work on the text, by Günther Jerouschek of the University of Hannover and to be published by the Georg Olms Verlag in early 1991, is merely a facsimile production of the original 1487 edition accompanied by an introductory essay $^{2}$; the essay, though competent,

1 "Die diesem 'verruchtesten und zugleich läppischsten, verrücktesten und dennoch unheilvollsten Buch der Weltgeschichte' durchweg zugemessene Bedeutung als einem entscheidenden Wendepunkt in der Geschichte des Hexenwesens steht in umgekehrtem Verhältnis zum Grad seiner Erforschung - als ein Produkt von Psychopathen und Kriminellen erschien es offenbar vielen näherer Lektüre nicht wert." Schwerhoff, "Rationalität im Wahn: Zum gelehrten Diskurs über die Hexen in der frühen Neuzeit" p. 56 .

2 Jerouschek, "500 Jahre Hexenhammer. Das Buch, die Frau, der Prozeß, Der Malleus Maleficarum und seine Bedeutung als literarische Grundlage der Hexenverfolgungen zu Beginn der Neuzeit", Unpubl. Manuscript, Hannover, 1987, passim. Although containing some discussion of the Malleus, the very recent study Early Modern European Witchcraft: Centres and Peripheries, edited by Bergt Ankarloo and 
is altogether too brief and contains no new information.

By and large, the historical community has accepted the opinion of the two great pioneers in European witchcraft studies, Joseph Hansen and Henry Charles Lea, both of whom view the text in the light of their own progressive, secular liberalism. For them, the Malleus is the highest summation of an aberrant scholastic theology inimical to the development of an enlightened rationalism. ${ }^{3}$ These sentiments concerning the text were perhaps most cogently expressed by R.H. Robbins - "[...] a thinking man has the right and duty to condemn the demonologists as obscurantists who set back the orderly development of civilization several hundred years." 4 Consequently, even among those historians who by no means share such a crudely reductionistic and jaundiced view of medieval theology, the bulk of discussion has been largely given over to assessing the precise extent of the role played by the Malleus in the development of the Witch Hunt, opinions varying from the vitally important ${ }^{5}$ to the marginal. ${ }^{6}$ In some ways more interesting are those works

Gustav Henningsen, has appeared too late for me to utilize it extensively in this dissertation.

3 Cf. Hansen, Quellen, pp. 360-407; Lea, History of the Inquisition, III, pp. 492-549; Materials Towards A History of Witchcraft, I, pp. 306-47.

4 Robbins, Encyclopedia of Witchcraft and Demonology, p. 338.

${ }^{5}$ Cf. Anglo, "Evident Authority and Authoritative Evidence", p. 14; Peters, The Magician, the Witch, and the Law, pp. 173-4. 
which employ the Malleus as evidence concerning some form of historical transformation in political, cultural, or social relations. One such example is Gregory Zilboorg's The Medical Man and the Witch During the Renaissance (1935), which exploits the text for brazenly polemical purposes. For Zilboorg, the Malleus is a failed prototype of a properly 'scientific' form of psychoanalytic study, with objectively discernible forms of psychosis being incorrectly diagnosed by the Dominican authors as demonic activity and possession. Although the fundamental tenets of the manual itself are erroneous ${ }^{7}$, Zilboorg holds, the phenomena described in the text do possess an objective reality, in this instance just tragically misunderstood; witchcraft beliefs and accusations are the result of sporadic outbreaks of collective

6 Cf. e.g., Norman Cohn: "The importance of the most famous of witch hunters' manuals, the Malleus Maleficarum [...] has been exaggerated... The stereotype of the witch was already fully developed half a century before the Malleus appeared - and more fully and more horrifically than in the Malleus itself. The Malleus has little to say about the witches' sabbat or about nocturnal flying, but both figure prominently in records of trials from the 1420 s and 1430 s onwards", Europe's Inner Demons, p. 224. Not only am I in disagreement with Cohn's general assessment, but I also provide textual evidence contradicting his latter claims concerning aerial transport and the sabbat. The essential fallacy of Cohn's position results from his construction of a false norm, taking sixteenth- and seventeenth-century treatises as paradigmatic examples of what a "proper" demonological text somehow should be.

7 For zilboorg's view of the Malleus, cf. The Medical Man and the Witch During the Renaissance, p. 9. "It is written with firm conviction and a fervent zeal which made the authors totally anaesthetic to the sight of wounds and blood, or to the smell of burning human flesh". 
psychosis brought about by heightened social tensions - whatever these might be $^{8}$ - and manifesting themselves in such a way that they may only be properly interpreted by someone adequately versed in the scientific manner. ${ }^{9}$ What is of far greater importance than Zilboorg's insights into the Malleus, which are of dubious value for a professional historian, is the way in which he deploys the text within the greater context of a form of historical interpretation which ideologically legitimizes the scientific and moral status of his own profession, psychiatric medicine. The Malleus is merely held to be the representative of one particular stage of an apparently teleological development of scientific understanding, culminating in contemporary medical practice; in short, "witches" are really mentally ill people previously misunderstood, but which we ourselves are now able to understand correctly - ergo, our own scientific institutions are justified through their capacity to overcome the inherent limitations and barbarities of previous eras.

A similar form of ideological appropriation, albeit from a wholly diametrical perspective, is also evident in Thomas Szasz's The Manufacture of Madness: A Cognitive Study of the Inquisition and the Mental Health Movement

${ }^{8}$ Cf. ibid., "What are traditionally called morals were at a very low ebb, and a severe conflict had arisen between traditional authority, which happened at that time to be ascetic, and the increasing hedonism of the age. The result was both natural and inevitable - a severe paranoid psychosis."

${ }^{9}$ Cf. ibid., pp. 1-64. 
(1971). If for Zilboorg the Malleus is one signpost along the teleological unfolding of the forces of the enlightenment, then for Szasz the Malleus is an equally important signifier of a teleological, anti-enlightenment process. As with Zilboorg, the fundamental issue at stake is not the Malleus itself, but a form of politics ${ }^{10}$; indeed, the two works mirror each other in a rather curious way. For Szasz, what is to be most lamented is precisely what Zilboorg most enthusiastically champions - the text as a prototype of a particular form of medieval understanding. For Szasz, however, such modes of perception have proven to be profoundly dysfunctional. In his view "mental illness" is an arbitrary cultural construct formulated and upheld by the medical establishment as a means of consolidating their political status within - and, by extension, their control over -society. Hence the cynical subtitle of the work; just as the Inquisition, via such texts as the Malleus, falsely constructed the existence of satanic populations, so does contemporary institutional psychiatry endorse the belief in the objective reality of mentally sick social categories and groups. ${ }^{11}$ What is of greatest interest to us is not merely the manner in which the Malleus can be placed within a contemporary political debate, but the ways in which it can be read concerning specific questions of power. This is perhaps

\footnotetext{
10 For a discussion of Szasz's position within the antipsychiatry movement, see Chapter Six of Peter Sedgwick's PsychoPolitics.

11 Szasz, The Manufacture of Madness, passim.
} 
most clearly evident in certain feminist analyses of the text. Radical feminists have frequently had recourse to the Malleus as a primary textual example of the alleged misogynistic tendency underlying patriarchal society that expressed itself not merely during the European Witch Hunt but throughout the entire occidental tradition of the political repression and social marginalization of women. 12 One of the most vocal of such feminist critis, Mary Daly, has of fered what is perhaps the classic exposition of the radical feminist view of witchcraft prosecutions as a vast phallocentric conspiracy deliberately intended to result in the elimination en masse of deviant femininity.

The massacre of women [...] masked a secret gynocidal [sic] fraternity, whose prime targets were women living outside the control of the patriarchal family, women who represented an option - an option of "eccentricity", and of "indigestability" [...] The women hunted as witches were (are) in a time/space that is not concentric with advocacy [... and must be] sucked back into the dead center of patriarchal darkness. ${ }^{13}$

The main trans-historical psychological motive/activating this process were, for Daly, the sado-masochistic sexual drives of a select and objectively identifiable population of male dominators - judges, lawyers, executioners, and phallocentric theologians, the archetypal examples of these categories being none other than

12 I in no way wish to convey the impression that I regard the sort of radical feminism which I shall be discussing here as the sole, or even the primary, representative of that complex interdisciplinary array of academic and political concerns collectively referred to as Feminism. For other feminist perspectives that avoid the reductionistic determinism which $I$ shall be criticizing below, see $T$. Moi, Sexual/textual Politics, and C. Weedon, Feminist Practice and Poststructuralist Theory. 
Heinrich Kramer and Jacob Sprenger. $\begin{array}{r}7 \\ { }^{14}\end{array}$

A similar perspective, combined with global environmentalist concerns, is forwarded by Carolyn Merchant ${ }^{15}$, who locates the hunting of witches, for her an exclusively female social category, within the wider contextual problem of the masculine will-to-power infusing the scientific/mechanistic drive to dominate (rape?) passive feminine Nature.

The image of nature that became important in the early modern period was that of a disordely and chaotic realm to be subordinated and controlled. Like the Mother Earth image [...] wild uncontrollable nature was associated with the female [...] The witch, symbol of the violence of nature, raised storms, caused illness, destroyed crops, obstructed generation $^{16}$ and killed infants. Disorderly women, like chaotic nature, needed to be controlled. ${ }^{17}$

Like Daly, Merchant cites the Malleus as a key textual example of the phallocentric representation and propagation of the sexist stereotype of the demonic woman/witch ${ }^{18}$ - as Merchant quite righlty points out, the text even employs the feminine form of the Latin for witchcraft (maleficarum) rather than the more commonly employed masculine (maleficorum). 19 This "most

14 Ibid., pp. 178-222.

15 Cf. Merchant; The Death of Nature, ch. 5, pp. 127-48.

16 Precisely how a symbolic representative of unchannelled fecundity could be widely perceived as inflicting sterility and blight is never explained by Merchant.

17 Merchant, The Death of Nature, p. 127.

18 Ibid., p. 134.

19 Ibid., p. 138 
famous sexist denunciation of witches" 20 , a leading "antifeminist tract" provids numerous and extensive "representations of the witches' Sabbat [which] present an image of widespread chaos and uncontrolled nature dominated by women engaged in exuberant, frenzied activity ${ }^{\prime 21}$, thereby succinctly consolidating $^{22}$, in textual form, the entire phallocentric sexual sadistic impulse underlying the background to the rise of the mechanistic revolution in science.

Prima facie, such an interpretation would seem to have much to recommend it, as it directly confronts one of the global problems of witchcraft studies that cries out for explanation, namely that in almost every society that possesses witch beliefs the overwhelming majority of those accused and persecuted are women. ${ }^{23}$ E. Willliam Monter has calculated that in southwestern Germany, from 1480 to 1700 , fully eighty-two per cent of all those accused were female and that over half of the condemned were single, frequently elderly, women, of ten widows. ${ }^{24}$ Edward Bever has also recently

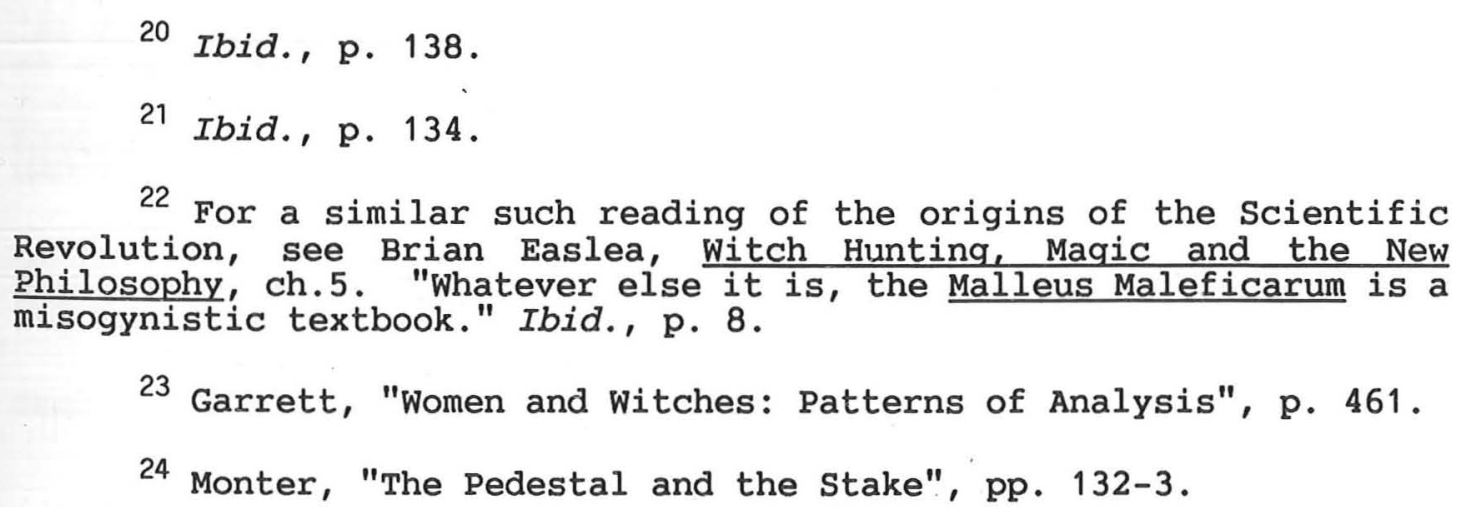


provided persuasive evidence that elderly and/or single women tend to dominate the lists of accused. ${ }^{25}$ By the beginning of the sixteenth century, the imaginative association between Woman and the Devil had taken such a firm hold in the public mind as in part to give rise to a separate and highly popular literary genre, the Teufelsbücher. ${ }^{26}$

Nevertheless, the judicial and cultural linkage between women and witchcraft is by no means as absolute as Daly's strident rhetoric would lead one to expect; although "legal records generally corroborate the predominance of women among people tried for witchcraft [...] their monopoly was not quite as complete as theory and legend would have us to believe". 27 For one thing, regional studies frequently reveal that although women almost always formed the clear majority, men could at times constitute sizeable minorities among the accused - in Castile, for example, from the end of the fifteenth to the sixteenth century, 132 men were formally accused, no less than twenty-nine per cent of the total of those tried for witchcraft. ${ }^{28}$ Similar trends are discernible within

25 Bever, "Old Age and Witchcraft in Early Modern Europe", pp. 164-83. Midelfort, however, argues that the stereotype of the witch as elderly widow frequently broke down during the larger hunts of the late sixteenth and early seventeenth centuries. Midelfort, Witch Hunting in South Western Germany: 1562-1684, p. 182. Cf. also Behringer, Hexenverfolqungen in Bayern, passim.

26 Cf. De Bruyn, Women and the Devil, passim; Roos, The Devil in Sixteenth-Century German Literature: The Teufelsbücher, passim.

27 Monter, "The Pedestal and the Stake", p. 132; Cf. also von Hehl, "Die Hexenprozesse der Frühen Neuzeit", pp. 248-9.

28 Ibid., p. 132. 
Germany. "The proportion of women dropped from 87 per cent in the first six large hunts to 76 per cent [...after 1631]. It is fair to say that as a mass hunt developed the number of men suspected usually rose, and that from the 1620's on men were generally more prevalent." 29 An even more striking development was the large number of children involved - from 1627 onwards, every large witch hunt in southwestern Germany began with children ${ }^{30}$, a trend inexplicable within the terms of Daly's own argument, unless she chose to make an appeal to the presumed pedophobic instincts of the judges. Furthermore, as we have seen with regards to Austria, especially concerning the Jackl trial at Salzburg, crucial attributes of the witch stereotype could be applied to male suspects with equally lethal results. ${ }^{31}$ At no point must it be

29 Midelfort, Witch Hunting in South Western Germany: 1562 1684. p. 179 .

30 Ibid., p. 179.

31 Dienst, "Magische Vorstellungen und Hexenverfolgungen", pp. 85-93. Malleus, II, Q.1, c.16, pp. 162-9 [Schmidt, II, pp. 161-76] is devoted to a discussion of those forms of maleficium that men are predominantly attracted to - "Super tres modos, quo viri \& non mulieres reperiuntur maleficiis infecti, per tria capitula \& primo de sagittariis maleficis". Several different editions of the Malleus have been used in the composition of this dissertation - see Bibliography. Unless specified otherwise, all quotations and references are taken from the Lyon edition of 1669. For reference purposes I have utilized the 1906 German translation by J.R.W. Schmidt [republished 1987] as my modern language version of the Malleus and equivalent page numbers have been provided in order to facilitate cross-referencing. Montague Summers' 1928 English translation has largely been avoided because of its excessive flaws. The first capital Roman numeral refers to the part of the Malleus (I-III), with the Question (Q.) and Chapter (c.) provided afterwards in the Arabic. Schmidt's translation reproduces the tripartite division of the Malleus, but the pages are not numbered sequentially throughout the work as a whole-therefore, I have provided the reference to the part with the appropriate page number. 
forgotten that the entire witch stereotype was in large measure derived directly from the archetypal representation of heresy, predominantly a male-centered of ence ${ }^{32}$, indicative of the ways in which a non-sex specific discursive formation could be rendered applicable to particular age and gender groups. Christina Larner, therefore, would appear to be completely right in arguing that witch hunting, while indisputably woman-related, can in no sense be regarded as necessarily woman-specific. ${ }^{33}$

These political and judicial themes shall be discussed in more detail in Chapter Four. Another possible line of enquiry, more fruitful than a strictly empirical one, is a form of literary analysis; that is, an examination of the ways in which Daly's and Merchant's presuppositions concerning textual reading determine their approach to the Malleus and the subsequent appropriation of their own, albeit perfectly legitimate, political programme. With such a critical literary approach the most basic error underlying the arguments of radical feminist scholars like Daly and Merchant now becomes readily apparent they establish a false correlation between authorial intention and authorial enunciation and, by doing so, collapse the vital distinction between origin and function. In the attempt to counter what they perceive as an essentialist masculine will-to-dominance with a counter-essentialist feminine will-to-non-

\footnotetext{
32 see below, passim.

33 Larner, Enemies of God, p. 197.
} 
dominance, they inadvertently reproduce one of the central features of that very phallocentric Aristotelian tradition which they strive to overthrow, namely the translation of an essentialist ontology into a political hermeneutics of intentionality. For them, demonological texts such as the Malleus become the sites of the expression of a primal sado-masochistic will of phallocentric theologians who self-consciously compose these treatises in order to secure successful domination over women, an inherent trans-psychologistic misogynism serving as the essential impetus behind the diverse manifestations of the sexual power politic - in short, men consciously intend to repress women and they write witchcraft manuals in order to do so. As I will demonstrate in my discussion of the Aristotelian and scholastic background to the misogynistic declarations of the $\underline{\text { Malleus }}^{34}$, the true relationship between text and author as evidenced by the text is in fact far more complex and ambivalent than either Daly or Merchant, both bound by the strict limitations of their radical counteressentialist politic, are either willing or able to allow.

This touches upon one of the most fiercely debated issues in contemporary literary criticism, the precise nature of the epistemological, political, and moral relationship of the author to his or her text. As Michel Foucault has argued in his seminal essay "What is an Author?":

Writing unfolds like a game that inevitably moves beyond its own rules 
and finally leaves them behind. Thus, the essential basis of [...] writing is not the exalted emotions related to the act of composition or the insertion of a subject into language. Rather, it is primarily concerned with creating an opening where the writing subject endlessly disappears. 35

Contrary to Daly's attempts to affix more responsibility to an objectively discernible act of authorial intentionality so as to vindicate a stance of accusatory political radicalism, Foucault reveals, through extended reflection, that authorial status and function elude the rigid categories of psychological essentialism.

We can conclude that, unlike a proper name, which moves from the interior of a discourse to the real person outside who produced it, the name of the author remains at the contours of texts - separating one from the other, defining their form, and characterizing their mode of existence. It points to the existence of certain groups of discourse and refers to the status of this discourse within a society and culture. The author's name is not a function of a man's civil status, nor is it fictional; it is situated in the breach, among the discontinuities, which gives rise to new groups of discourse and their singular mode of existence [...] the function of an author is to characterize the existence, circulation, and operation of certain discourses within a society. 36

The main issue which justifies this rather lengthy critique of the radical feminist interpretation of the witchcraft prosecutions is the need to elaborate the theoretical assumptions which mar an adequate appreciation of the historical status of the Malleus. Merchant and Daly, because of their essentialist political position, must necessarily view the witchcraft prosecutions

35 Foucault, "What is an Author?", p. 116.

36 Ibid., pp. 123-4 
within the more general context of a teleological male-centered drive for power, revealed, in the particular, through their subjection of the Malleus to a stringently reductionistic understanding of authorial intentionality grounded upon a feminist pseudo-psychoanalytic critique of the phallocentric personality of the authors. Apart from the banal objection that we simply do not possess sufficient biographical evidence concerning Kramer's personality - Bishop Golser's complaint of the inquisitor's senile childishness notwithstanding ${ }^{37}$ this attempt can be successfully criticized on a more sophisticated level. Although it is indisputable that witch hunting and those treatises composed to justify its legitimacy could be employed in the service of the regulation of female sexual and social identity, it does not follow that such hunts or texts originated as the deliberate intention to do so, a point which will be demonstrated through invalidating the significance of Kramer's own allegedly phallocentric personality by situating it within the context of a scholastic discursive tradition that extended far beyond the boundaries of his own identity as an autonomous author/subject. Demonological treatises such as the Malleus can in no way be regarded as the primal grounds of emergence of an impetus to hunt women as witches; rather, by formulating a discursive practice within which a correlation between woman and witch could be articulated, an ideological concept was generated which could be endlessly appropriated and

37 See below, Chapter Three. 
reappropriated for diverse political and social purposes within different historical contexts. It is only by placing the Malleus within the widest possible network of causal determinants of a decidely anti-essentialist and antiteleological nature, that we can begin adequately to appreciate the significance and complexity of its role as a causal factor in the development of the witchraft persecutions.

Criticizing the interpretative models of others forces one, almost out of logical necessity, to critically consider what sort of alternative model may be offered in their place. Although a text like the Malleus, by its very extensiveness, invites numerous forms of interpretative strategies, I think that the single best approach available would be one that employed some of the features of what is loosely referred to as "post-structuralism", especially of the neo-Foucauldian variety. 38 The interpretative analytics of post-structuralism allow one to circumvent most effectively that twin-headed historiographical hydra of reductionism and determinism, the bane of all more orthodox histories which fail adequately to appreciate the importance of divergence, discontinuity, and singularity - in short, the inherent problematics of the concrete. The

38 I am perfectly well aware, of course, that post-structuralism can in no way be considered a coherent, established orthodoxy such as neo-Marxism or neo-Freudianism, even less that Foucault can be forwarded as some sort of paradigmatic representative of such a school. However, as Richard Harland has pointed out, post-structuralism represents an episteme, an "underlying framework of approach and assumption. Even when Derrida refutes Levi-Strauss or Baudrillard declares war on Foucault, the hostilities are still conducted over common ground." Harland, Superstructuralism, p. 2. 
general argumentative structure of my thesis therefore proves itself amenable to what I take to be certain central aspects of the post-structuralist programme in at least two ways. The first is that the Malleus itself is a written work, a text, the very sort of cultural artifact that traditional historians, especially of the Marxist variety, have tended disparagingly to banish to that nebulous twilight zone known as the "superstructure". However, as Richard Harland has recently argued, what all those designated as post-structuralists

share is a certain characteristic way of thinking about superstructures. To put it roughly, the Superstructuralists [post-structuralists] invert our ordinary base-and-superstructure models until what we used to think of as superstructural actually takes precedence over what we used to think of as basic. 39

I will thus argue for the irreducible - if not overly deterministic - causal importance of a written text such as the Malleus within the array of preconditions governing the emergence of the witchcraft prosecutions. Secondly, as historical agents Institoris and Sprenger, both Dominican inquisitors, themselves suggest correlations between the actual procedures of witch-hunting as they were practised in the late fifteenth century, and the thematic similarities that underlie both the archaeology of knowledge and the human sciences, and the genealogy of power/knowledge, two of the most pertinent topics in post-structural analysis. ${ }^{40}$ If Foucault takes the study of

39 Ibid., pp. 1-2.

40 Dreyfus and Rabinow, Michel Foucault: Beyond Structuralism and Hermeneutics, pp. 102-3. 
history to be "the descriptive analysis and the theory of [the] transformations" of discursive formations ${ }^{41}$ and if it truly is his mature opinion that his own objective had always been "to create a history of the different modes of objectification which transform human beings into subjects" 42 , then a post-structural interpretative analytic lends itself as an ideal methodological instrument for examining those historical pre-conditions of the emergence of the Witch Hunt both situated within and reflected by the finished text of the Malleus. Both of the alleged authors were fully certified Dominican theologians, conveyers of the Realist theology of neo-Thomistic scholasticism; simultaneously, they were agents of the political institution of "the Inquisition", itself a major structural appendage of the "Hounds of God"'" - that is, a political organization whose procedural operations were both suffused with and rationalized by an intellectual apparatus of a highly specific form of theological discourse. It is thus greatly tempting to view the witch-hunting inquisitor of the late Middle Ages, in this particular instance Kramer and Sprenger, as one particular, though highly illuminating, exemplification of the more general process of the establishment of a network of power/knowledge over the postulated subject - i.e. the satanic witch - both by and through the formulation of and recourse to a specific discursive formation, late fifteenth-century

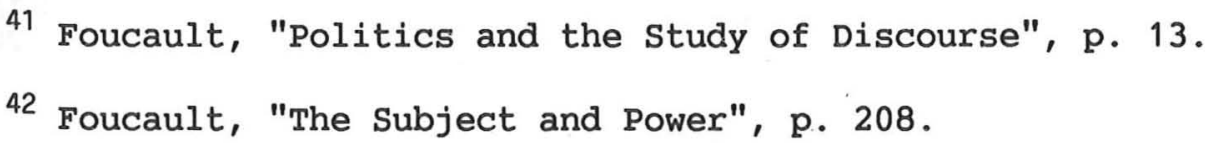


neo-Aristotelian scholastic theology. ${ }^{43}$ The obvious objection that can be raised at this point, namely that the historical record points to numerous instances of the Inquisition as exerting a moderating influence upon the hunting of witches ${ }^{44}$, can be shown to be irrelevant. For what such an objection implicitly presupposes is precisely what the current study tries to avoid namely, the quasi-teleological assumption that the Dominican Inquisition produced witch-manuals with the conscious intention of provoking the masspersecution of witches. A more careful study of the Malleus reveals rather that the Inquisition was merely the medium, both political and intellectual, through which such a text could emerge in the first instance. Its subsequent judicial deployment, if at all, would depend directly upon the particular ad hoc conditions prevailing during the actual witch persecutions themselves. In this sense, the Inquisition served as the "materiality" of the emergence of the stereotype of the demonic witch-figure. ${ }^{45}$ And it is in this regard that Sydney Anglo has quite rightly indicated that the $\underline{\text { Malleus }}$

affords a comprehensive summary of arguments for [the] persecution [of

43 Cf. Michel Foucault: "The great empirical knowledge that covered the things of the world and transcribed them into the ordering of an indefinite discourse that observes, describes and establishes the 'facts' (at a time when the western world was beginning the economic and political conquest of this same world) had its operating model no doubt in the Inquisition", Discipline and Punish, p. 226.

44 Baroja, The World of the Witches, pp. 152,180; Henningsen, The Witches' Advocate, p. 389; Kamen, The Spanish Inquisition, pp. 283-300.

45 Foucault, The Archaeology of Knowledge, p. 103. 
witches], together with a persecution method, which has precisely that combination of unoriginality, popularity, and influence so valuable to the historian of ideas seeking to discover conventional, rather than atypical modes of thought. ${ }^{46}$

With this consideration in mind I shall now examine some of the crucial elements in the gestation of that nebulous array of phenomena collectively referred to as the European Witch Hunt and the ways in which they converged in the actual composition of the text.

46 Anglo, "Evident Authority and Authoritative Evidence", p. 14. 


\section{CHAPTER ONE:}

THE PLACE OF THE TEXT.

Any critical examination of the historical context underlying the composition of the Malleus Maleficarum and its place in the rise of the European witch persecutions should refrain from resolving the various causal determinants into some sort of teleological understanding of ultimate origins, but rather interpret them in an inherently non-linear fashion, implying a radical and irreducible multiplicity of origins. As Robin Briggs has perceptively remarked, it is "in fact far easier to understand witchcraft beliefs and persecution synchronically than diachronically."1 Concomitant with this project is the attempt to situate the text within a series of historically emergent relationships of power, disparate political and judicial developments vitally interacting with changes in the modes of literary and textual production.

In his useful study European Witch Trials: Their Foundations in Popular and Learned Cultures, 1300-1500, Richard Kieckhefer draws up a detailed "calendar" of recorded witch trials occurring throughout the fourteenth and fifteenth centuries. Although Kieckhefer's "calendar" suffers from the obvious shortcoming of failing to consider accusations apart from actual prosecutions, he demonstrates that any sort of coherent notion of maleficium as a clearly

1 Briggs, "Witchcraft and Popular Mentality in Lorraine: 1580$1630 "$, p. 346 . 
definable legal of fence existed no time prior to $14000^{2}$ In the first phase that Kieckhefer identifies, from 1300 to 1330 , there is only a very marginal rate of prosecutions for charges of malefice, on average only one per annum for the whole of western Europe. What is most significant, however, is that virtually all of the recorded accusations occurred within a curial setting, e.g. the papal court of John XXII, and entailed the reputed employment of ritualistic magic. ${ }^{3}$ In the second phase, from 1330 to 1375 , the total number of prosecutions did not undergo a substantial alteration, but, in general, accusations began to infiltrate downwards on the social ladder. ${ }^{4}$ The third phase, from 1375 to 1435 , witnessed a sharp overall increase in the total number of trials accompanied by the radically new feature of accusations of diabolism, hitherto unknown with regards to prosecutions of maleficium. ${ }^{5}$ The fourth and final phase, from 1435 to 1500 , was a period of comparatively intense witch hunting, anticipating if not equalling the dimensions of the sixteenth-century persecutions. Significantly, it was this fourth phase that witnessed a noticeable upturn in the publication of witchcraft treatises of which the Malleus Maleficarum was the most infamous product. As

2 Kieckhefer, European Witch Trials, pp. 106-47. Diabolic witchcraft is "a fifteenth-century phenomenon, and its genesis must be explained accordingly." Murray, "Medieval Origins of the Witch Hunt, p. 66.

3 Kieckhefer, European Witch Trials, pp. 10-12.

4 Cf. ibid., p. 15.

5 Cf. ibid., p. 18. 
Kieckhefer points out, 1435 was the date of the first printing of the Formicarius of Johannes Nider, one of the very first ecclesiastical texts on diabolism and a major source of information about malefic-related activities for Heinrich Institoris. 6

Historians have usually attempted to render intelligible this seemingly inexplicable increase in the number of witchcraft trials during the late Middle Ages through advocating either what may very generally be referred to as the "from the bottom up"- or the "from the top down"-mode of explanation. The former model tends to lay primary emphasis upon the diverse socio-economic factors at work on the purely popular levels, stressing in particular the social tensions resulting from rigid structural alteration, including urbanization ${ }^{7}$ and the post-feudal collapse of traditional forms of social obligation, such as charity and communal assistance. ${ }^{8}$ The basic difficulty with this functionalist approach is, of course, that it is not only very difficult to substantiate with conclusive empirical evidence; it is also circular. The view of accusations of witchcraft as being somehow dysfunctional, arising from increasing social stress, implicitly assumes the prevalence of largely non-stressful social relations in the period prior to the outbreaks of trials for maleficium - a highly dubious assumption

6 Cf. ibid., p. 23; see below, Chapter Seven.

7 Ibid., p. 95.

8 Macfarlane, Witchcraft in Tudor and Stuart England, pp. 147-207; Thomas, Religion and the Decline of Magic, pp. 665-80. 
indeed, especially, when one considers the recent efforts by numerous scholars to trace the origins of capitalistic modes of production even further back into the past. Furthermore, the "dysfunctionalist" approach fails adequately to appreciate the subtle difference between recorded judicial persecutions of suspected witches and the total number of accusations of maleficium, only a small number of which would actually have been recorded. The crucial factor at work in the fifteenth century seems not to be the apparent rise in the "real" number of accusations, but, rather, the judiciary's relatively increased concern with processing such accusations, that thrusts the inherent political elements implicit in witchcraft trials into the historical limelight. The second model, although seemingly less politically naive, likewise suffers from certain decisive limitations. Traditionally the domain of such liberal historians as Joseph Hansen $^{9}$, H.C. Lea ${ }^{10}$, G.L. Burr ${ }^{11}$, and R.H. Robbins ${ }^{12}$, this model's view of an unenlightened despotic theocracy forcing irrational witchcraft beliefs upon a passive, ignorant peasantry in an exclusively repressive mode of political domination is betrayed not only by it's advocates' rather puerile anti-clericalism but also by their implicitly ethnocentric notion of Reason. Similarly prey to

9 Hansen, Quellen, passim; Hansen, Zauberwahn, passim.

10 Lea, A History of the Inquisition in the Middle Ages, passim.

11 Burr, "The Literature of Witchcraft", passim.

12 Robbins, The Encyclopedia of Witchcraft and Demonology, passim. 
such limitations is a neo-Marxist rendition of the "from the top down"-model, which sees the Witch Hunt as the pursuit of capital extraction through ideological mystification. ${ }^{13}$ Not only does this approach reduplicate the basic flaw of the functionalist model - postulating a marked increase of social stress within "late medieval society", a direct result of ignoring the distinction between rates of accusation and rates of prosecution -, but it also completely begs the question. For what it fails to address is the precise issue at stake, namely, why it was in the fifteenth century and not before that there was such a display of concern with satanic witches in particular, and not with some other better-established variety of social deviant. A further problem is the basic fact that the majority of the accused were not propertied but rather economically marginal old women. In many instances the State actually appears to have lost money in conducting trials and executions. ${ }^{14}$ Although it is indisputable that witchcraft beliefs and persecutions could be used in a thoroughly repressive and/or exploitative fashion the inherent reductionism

13 Cf. Marvin Harris: "The practical significance of the witch-mania [...] was that it shifted responsibility for the crisis of late medieval society from both Church and State to imaginary demons in human form. Preoccupied with the fantastic activities of these demons, the distraught, alienated, pauperized masses blamed the rampant Devil instead of the corrupt clergy and the rapacious nobility." Harris, Cows, Piqs, Wars, and Witches, pp. 237-8. For a concise discussion of the Marxist perspective see Schwerhoff, "Rationalität im Wahn: Zum gelehrten Diskurs über die Hexen in der frühen Neuzeit", p. 49.

14 Midelfort, witch Hunting in Southwestern Germany: 1562-1684, pp. 174-89. 
present in such a model clearly proves it to be inadequate in coping with the sheer complexity, the irreducible "historical density" of the Witch Hunt. 15

Clearly what all models fail to explain, or even adequately to take into account, is the actual process of the ideological transformation of the stereotype of the demonic witch-figure itself, from aristocratic ritualist magician and peasant "cunning woman" into satanic heretic and diabolic subversive. As the most cursory reading of Kieckhefer's "calendar" demonstrates ${ }^{16}$, the stark transition in the nature and status of the witch is at least as striking as the rise in the total number of witch trials. I think that a critical study of the actual conditions of the historical formation and representation of this fictitious social category, achieved through the demonization of the traditional witch figure as a signifier of heretical diabolism and reproduced through cultural artefacts such as the Malleus Maleficarum, not only provides us with some crucial insights into the origins of the Witch Hunt but that it may also supply historians with at least some means of formulating a more general synthetic overview of the persecutions, integrating the most attractive features of both models ${ }^{17}$ alluded

15 For a useful discussion of various explanatory models, see Kephardt, "Rationalists vs. Romantics Among Scholars of Witchcraft", pp. $326-42$.

16 Kieckhefer, European Witch Trials, pp. 106-47.

17 An exemplary study in this regard is Carlo Ginzburg's The Night Battles, which details not only the gradual formation of the diabolic stereotype of the witch, but also the subtle ways in which such a cultural image was disseminated throughout and actively replicated by both "high" and "low" cultures. Within another context Ginzburg has remarked: "The sabbat myth was not a sudden invention but the coherent 
to. It becomes necessary to examine in more detail the complex historical processes underlying the formation of the stereotype of the satanic deviant itself. $^{18}$

As R.I. Moore has indicated:

The eleventh and twelfth centuries saw what has turned out to be a permanent change in western society. Persecution became habitual. That is to say not simply that individuals were subject to violence, but that deliberate and socially sanctioned violence began to be directed, through established governmental, judicial and social institutions, against groups of people defined by general characteristics such as race, religion, or way of life, and that membership of such groups in itself came to be regarded as justifying these attacks. 19

By the beginning of the central Middle Ages, there had emerged to the forefront of judicial discourse a classificatory concept of the satanic deviant, the product of a venerable intellectual and cultural tradition whose lines of descent can be traced at least as far back as the Roman Imperium's attempts to label as subversive marginal underground religious groups including, ironically enough, apostolic Christians. ${ }^{20}$ Attributes unique to this idiosyncratic stereotype

result of a slow process. The real problem is to reconstruct how the fusion of the stereotype's various elements became possible." Ginzburg, "The Witches' Sabbat", p. 41. Cf. also Ginzburg's most recent work Hexensabbat, passim.

18 Joseph Hansen argues that the historical and cultural originality of the Malleus lies precisely in its demonstration of the necessary linkage between witchcraft and heresy as well as between witchcraft and feminity. Hansen, zauberwahn, pp. 473-501. See below, Chapter Three.

19 Moore, The Formation of a Persecuting Society, pp. 4-5.

20 Cohn, Europe's Inner Demons, pp. 1-15. 
included the practice of ritual murder, orgiastic sexual license, and cannibalistic infanticide, combined with an unappeasable lust for social domination. ${ }^{21}$

Throughout the High Middle Ages, for reasons varying with the historical particularities of each specific social group, the Leper ${ }^{22}$, the Jew ${ }^{23}$, the Magician $^{24}$, the Knight Templar ${ }^{25}$, and, most importantly, the Heretic ${ }^{26}$, were all, at one time or another, subjected to the stereotyping perception of the anti-social satanic deviant, striving to disrupt the celestial and social orders through blasphemous violations of and transgressions against the cohering

21 Cf. ibid., "Ritual murder and cannibalistic feasts belonged to one particular, traditional stereotype: the stereotype of the conspiratorial organization or secret society engaged in a ruthless drive for political power. Such a group is absolutely outside humanity; and its relationship to mankind as a whole can only be one of implacable enmity", pp. 7, 12 .

22 Brody, The Disease of the Soul, passim; Estes, "The Medical Origins of the witch Craze", pp. 272-3, 274; Moore, The Formation of a Persecuting Society, pp. 45-60; Richards, The Medieval Leper, passim.

23 Hsia, The Myth of the Ritual Murder, passim; Moore, The Formation of a Persecuting Society, pp. 27-45; Pullan, The Jews of Europe and the Inquisition of Venice 1550-1670, passim; Trachtenburg, The Devil and the Jews, passim.

24 Peters, The Magician, the Witch, and the Law, pp. 63-84. A more detailed discussion expanding upon the highly complex relationship between magician-heretic and witch will be provided below, in Chapters Five to Seven; here it will be sufficient to situate the figure of the demonic ritual magician as one particular stereotypical formation within the more general inter-social discursive formation developed from the twelfth to fifteenth centuries.

25 Barber, The Trial of the Templar, passim; Burmann, The Templars, pp. 158-75; Partner, The Murdered Maqicians, pp. 50-85; Peters, The Maqician, the Witch and the Law, pp. 63-84.

26 Moore, The Formation of A Persecuting Society, pp. 11-27. 
societal bonds of normality. ${ }^{27}$ It is within the confines of this more general context of the satanic subversive that the notion of diabolic witchcraft must be firmly situated, the transgressions represented by the stereotypical formulations of satanic maleficia, like those of other demonically inspired deviants, serving as "a kind of reverse or counter-sublimation, undoing the discursive hierarchies and stratifications of bodies and cultures which [...] society has produced as the mechanism of its symbolic dominance." 28

This is particularly evident in the intimately aligned cultural notions of the satanic heretic and the satanic leper ${ }^{29}$, the gestation of which served not only as an immediate ideological precursor to the diabolic witch figure, but whose discontinuous histories strikingly parallel the formation of the concept of satanic

27 Ibid., pp. 61-5.

28 Stallybrass and White, The Politics and poetics of Transgression, pp. 200-1.

29 Although the product of a discursive formation - see Hsia, The Myth of Ritual Murder, pp. 42-65, - the satanic Jew shall not be discussed within this context, for despite frequent trials for sorcery, no Jew was apparently ever executed for witchcraft. Brian Pullan has, however, drawn attention to the gravity of accusations of satanic misdemeanour: "Jurisdiction over the Jews [...] called into play the negotiating machinery built into the Inquisition itself through the association of laymen with the pursuit of heresy [...]. At one time or another, Jews or former Jews were denounced for, investigated for or actually charged with many of the offences within the Inquisition's purview - with heresy or apostasy, suspicion of heresy, heretical blasphemy, misuse of the sacraments, insults to converts or clergy, or involvement in superstitious practices ranging from the unorthodox exorcism of evil spirits to the detection of thieves by supernatural means", Pullan, The Jews of Europe and the Inquisition of Venice 155001670 , p. 14 . 
maleficium. What we are presented with, then, is a history of fragments. 30

Although more orthodox historians such as Steven Runciman ${ }^{31}$ have postulated an essential underlying unity, it becomes obvious under closer scrutiny that the entire cultural phenomenon known as 'heresy' can in no means be classified in accordance with any one set of causal determinants ${ }^{32}$; it seems impossible to trace adherence to heretical doctrines along either specific class or geographical lines. 33 What most heretical movements do seem to share is a popular dissatisfaction about the failure of the ecclesiastical establishment adequately to cater for the religious and spiritual demands of the laity, demands which helped to precipitate, and which were subsequently intensified by, the

30 "In different places and circumstances they [heretics] appeared ostensibly for different reasons. Eventually a few succeeded in evolving doctrine and organization which could be sustained over a wide area of Europe, and from generation to generation, but most of them were the work of personal leaders, and faded and withered when their inspiration passed on to another place, another life. Although society did not wholly fail to recognize this discontinuity, it treated heresy as a single enemy, and secular and ecclesiastical potentates settled to the task of decapitation confident that all heads belonged to one monster. The monster had being in the form of a concept of heresy whose essential unity was not diminished by the diversity of its manifestations, but it remains to consider a question which would have appealed to the schoolmen, whether it also had reality outside the perceptions of its observers, and did in fact confront Church and Society with any general challenge." Moore, The Origins of European Dissent, p. 263 .

31 Runcimann, The Medieval Manichee, passim.

32 "The surviving evidence shows a bewildering variety of [causal] associations [of heresy] because they existed, and shows them irregularly because they were irregular. The threat of heresy, like the power of Catholicism, rested not on the foundation of one force but on the capacity to ally itself with many." Ibid., p. 267. See also Wakefield, Heresies of the Hiqh Middle Ages, p. 19.

33 Ibid., p. 264; Lambert, Medieval Heresy, p. xv. 
Gregorian reform movement. ${ }^{34}$ Yet despite, or perhaps precisely because of such diffuse grounds of emergence, religious authorities utilized the highly centralized political structure of the Church to formulate a unified definition of heresy as organized anti-social subversion in order to effectively undermine unauthorized forms of religiosity. 35

The primary medium through which this was accomplished was literary and textual production; twelfth-century monastic writers, labouring under the aegis of the Church Fathers, transferred to contemporary suspect religious groups the same characteristics accorded to them during the Patristic era, on the assumption that they were ancient heresies in revived form. ${ }^{36}$ A stereotypical image of the anti-social heretic was widely disseminated, postulating linkages

34 Moore, The Origins of European Dissent, p. 264.

35 "Under papal leadership the Church evolved a coherent counter to the threat of popular heresy in the same decades when the Cathars, who would realize that threat most persistently and ubiquitously, appeared, settled, and organized their congregations in western Europe. The coincidence was largely incidental. The reaction, both in analysis and in devising means to undo the successes of the heretics, to defer their patrons, root out their adherents, and secure their conviction, was formed in part by the Church's own long history and heritage, and partly by its immediate experience of two quite distinct, though overlapping phases of western heresy, those of the native clerical preachers and the Cathars, neither of which owed anything directly to the other. That the discontinuity of heresy was not always clearly recognized certainly did not hinder, and very possibly assisted, the continuity of response." Ibid., pp. 261-2.

${ }^{36}$ Cf. Peters, The Magician, the Witch, and the Law, Chapter Two. Edward Peters is one of the few scholars adequately to appreciate the full significance of the purely literary element in these historical trends. "Historians of magic, heresy, and witchcraft have not customarily emphasized the importance of rhetoric in shaping, preserving, and transmitting many of the most conspicuous features of invective against ecclesiastical deviants to later writers who took them perfectly seriously and literally." Ibid., p. 23. 
between heresy and obscene satanic ritualistic observances such as the osculum infame ${ }^{37}$ which, in turn, were almost always associated with unbridled sexual licentiousness. Indeed, sexual excess and perversity became the main signifier of spiritual unorthodoxy within twelfth-century theological polemics. ${ }^{38}$ Not surprisingly, contemporary authorities began to postulate correlations between heresy and that other extreme, and highly visible, form of socio-moral transgression, leprosy. ${ }^{39}$ The medieval leper, the victim of a disease that does not easily lend itself to classification - medieval authors presumably based their accounts on observations of multiple pathological conditions 40 - was transformed into a potent symbol of moral and spiritual decay, representing at various periods simony, avarice ${ }^{41}$ and, most importantly, lust and unrestrained 212 .

37 Bullough, "Postscript: Heresy, Witchcraft and Sexuality", p.

38 Lerner, The Heresy of the Free Spirit, pp. 10-34. In 1287 premarital sexuality had even been denounced as a form of heresy. Brundage, Law, Sex, and Christian Society in Medieval Europe, p. 517. "Once the medieval equation of active sexuality with religious deviancy is accepted, it is understandable why it could be extended to other fields." Bullough, "Postscript: Heresy, Witchcraft, and Sexuality", p. 210 .

39 "In the Middle Ages, the leper was a social text in which corruption was made visible; an exemplum, an emblem of decay. Nothing is more punitive than to give a disease a meaning - that meaning being invariably a moralistic one." Sontag, Illness as Metaphor, p. 62. Cf. Moore: "The imbalance of the humours which caused bodily illness might also manifest itself in moral forms, and therefore ... disease and sin were directly related to each other, and could be classified accordingly." Moore, The Birth of Popular Heresy, p. 15; also Richards, The Medieval Leper, p. 53.
40 Brody, The Disease of the Soul, p. 42 .
41 Ibid., p. 128. 
between heresy and obscene satanic ritualistic observances such as the osculum infame ${ }^{37}$ which, in turn, were almost always associated with unbridled sexual licentiousness. Indeed, sexual excess and perversity became the main signifier of spiritual unorthodoxy within twelfth-century theological polemics. ${ }^{38}$ Not surprisingly, contemporary authorities began to postulate correlations between heresy and that other extreme, and highly visible, form of socio-moral transgression, leprosy. ${ }^{39}$ The medieval leper, the victim of a disease that does not easily lend itself to classification - medieval authors presumably based their accounts on observations of multiple pathological conditions ${ }^{40}$ - was transformed into a potent symbol of moral and spiritual decay, representing at various periods simony, avarice $\mathrm{41}^{41}$ and, most importantly, lust and unrestrained

37 Bullough, "Postscript: Heresy, Witchcraft and Sexuality", p.

38 Lerner, The Heresy of the Free Spirit, pp. 10-34. In 1287 premarital sexuality had even been denounced as a form of heresy. Brundage, Law, Sex, and Christian Society in Medieval Europe, p. 517. "Once the medieval equation of active sexuality with religious deviancy is accepted, it is understandable why it could be extended to other fields." Bullough, "Postscript: Heresy, Witchcraft, and Sexuality", p. 210 .

39 "In the Middle Ages, the leper was a social text in which corruption was made visible; an exemplum, an emblem of decay. Nothing is more punitive than to give a disease a meaning - that meaning being invariably a moralistic one." Sontag, Illness as Metaphor, p. 62. Cf. Moore: "The imbalance of the humours which caused bodily iliness might also manifest itself in moral forms, and therefore... disease and sin were directly related to each other, and could be classified accordingly." Moore, The Birth of Popular Heresy, p. 15; also Richards, The Medieval Leper, p. 53.

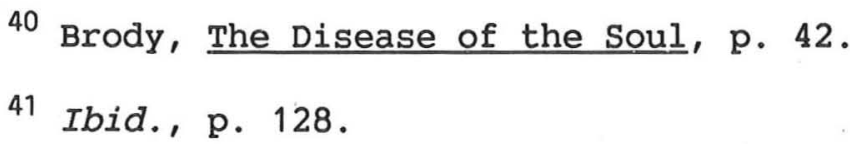


carnal passions. ${ }^{42}$ The cultural notion of leprosy provided ecclesiastical

authorities with an ideal 'ready made' stereotype with which to classify and

thereby condemn their heretical opponents.

The comparison between heresy and leprosy which is so regularly made in [medieval] documents [...] is not a casual metaphor, but the expression of the conviction that the two conditions were the moral and the psychological expressions of the same disorder. That conviction was strengthened by numerous similarities between them [... Like heresy, leprosy] appeared suddenly and unpredictably, spread rapidly, was very rarely cured, was passed from parents to children, and showed itself most unpleasantly and alarmingly among the poor who, finding themselves excluded from the communities to which they belonged, in the squalid and isolated encampments which became leper villages, or wandered through the countryside in bands causing terror by their appalling appearance and desperate conduct. The persistent, though mistaken, belief that leprosy is contagious gained ground in the later part of the twelfth century, and it was also believed that lepers were exceptionally lascivious, and that the disease was sexually transmitted. ${ }^{43}$

It is Moore who, once again, has drawn out the full political implications inherent

in this ideological concept that was hammered out in the course of

twelf th-century theological development and ecclesiastical reform.

This tangled nightmare of association and assumption was part of the background against which the authorities of Church and State worked out their response to the growing problem of heresy. It was only one of the forces which seemed to threaten the security of Christian society, but just as the fearful always exaggerated the coherence of the threat which the heretics themselves presented the web of common attitudes and

42 Ibid., p. 129. Cf. also "The connection between leprosy and carnality is ubiquitous in medieval culture, and the religious, medical, and popular understandings of leprosy influenced and reinforced each other." Ibid., p. 143.

43 Moore, The Birth of Popular Heresy, p. 5; See also: Moore, "Heresy as Disease", pp. 1-11. 
responses to other sources of anxiety shows how, both consciously and subconsciously, they also tended to assume that all their enemies were in reality the same one. ${ }^{44}$

The role that the stereotype of the diabolic heretic/leper played

in the outbreak of the witchcraft persecutions may be seen even more clearly when examined in relation to a series of concomitant transformations in judicial practice and discourse that occurred from the twelfth to the fourteenth centuries, bound to the gradual abolition of trial by ordeal. By the end of the twelf th century rising intellectual concerns as to whether the ordeals provided just results (as they could be affected by magical practices) 45 and whether the ordeals were legitimately sanctioned by the canons (as they could be interpreted as a means of tempting God $)^{46}$, prompted ever greater numbers of clerics to

44

Ibid., pp. 249-50. See also Ginzburg on the waves of persecutions against lepers and Jews in France in 1321 following rumours of poisoned wells: "The main link is provided by the conspiracy itself - or by its myth [...] For the first time in European history, the chain provided by the conspiracy myth (devil - Moslem kings - Jews - lepers) connected internal and external enemies, giving political and religious authorities the opportunity to pinge society on a mass scale. In that chain, witches were still absent - but not for long." Ginzburg, "The Witches' Sabbat", p. 43. For a short while, the leper/poisonedwell conspiracy "was seen as the ultimate threat to the faith as conceived by the orthodox: a plan by subversive elements, both inside and outside society, to overthrow the whole structure of Christendom." The subsequent arrest and torture of suspect lepers produced depositions citing Jewish and Moslem assistants in the conspiracy and reports of congregations of lepers performing anti-Christian rituals essentially identical to those conducted by lepers and Templars; Barber, "Lepers, Jews and Moslems: the Plot to Overthrow Christendom in 1321", pp. 1,6,16-17. A discussion of some of the exact correspondences between the respective activities of both heretic and witch, such as the Sabbat, will be provided in Chapter Seven.

Bartlett, Trial by Fire and Water, p. 77 .

46

Ibid., p. 81 
cast serious aspersions upon the validity of this mode of justice. These rather abstract concerns were intimately bound up with the rise of the university system and scholastic jurisprudence ${ }^{47}$; historians have long pointed to the intricate relations governing the emergence ${ }^{48}$ of both scholastic theology and the (re-)emergence of Roman jurisprudence occurring throughout the twelfth century. This development of a new form of both philosophical and judicial rationalism carried within it a distinct set of political connotations.

47 "The uncanonical nature of the practice [of ordeals] was of much greater importance in an age when canon law was, on the one hand, codified and studied more intently than ever, and, on the other, enforced more effectively. The issue, of what was canonical and what was not, was now highlighted [...] By around 1150 both theology and canon law had become academic disciplines. As a result, questions which had remained unresolved or disputed for centuries were subjected to intense intellectual winnowing and crystallized or polarized. New dogmatic definitions were advanced on such topics as the number and nature of the sacraments, the rules of marriage, and the process of transubstantiation. The ordeal, too, was placed under this new and rigorous scrutiny [...] The emergence of a clear papal voice on this subject in the later twelfth and early thirteenth century was deeply shaped by theological and legal discussion." Ibid., p. 83.

$48 \mathrm{Cf}$. also John Baldwin: "The Romanists of the twelfth and early thirteenth centuries were preoccupied with the re-establishment of ancient Roman jurisprudence. To them full and clear legal proof consisted mainly of written instruments and witnesses." Baldwin, "The Intellectual Preparation for the Canon of 1215 Against Ordeals", p. 66. According to Stephen Kuttner, such trends were the result of "what may be called a climate of desire for learning: it manifested itself in what was more than a search, rather an impassioned quest for understanding the universal order that must exist behind the accumulated, fragmentary, and often contradictory authorities of the past. The quest was no less where it concerned a body of auctoritates dealing with contingent realities (law) rather than the eternal order of salvation (theology); especially so if these were considered texts of authority because they rested, ultimately, on the authority of Rome: the imperial Rome of Justinian's Corpus, and the Apostle's Rome in the text of canon law [...] the idea of Roman auctoritates was always in the back of the mind of those who first endeavoured to transform the individual auctoritates, in both laws, into a coherent whole." Kuttner, "The Revival of Jurisprudence", p. 310. 
In a sense, the exercise of reason, as fostered by the intellectuals and the [ecclesiastical] reformers of the late eleventh and twelf th centuries, was the most blatant exercise of authority at all. For appeal to reason in clerical controversy invariably implied, at that time, that men could be expected to obey rapid and trenchant decisions - the outcome of syllogism, the production of an authoritative written text. ${ }^{49}$

In turn, this new kind of juro-theological reason proved highly efficacious in furthering the concrete political goals of the Gregorian reform movement, as the systematic opposition to trial by ordeal played a vital role in the more general program of delineating ever more clearly the lines of demarcation between the profane and the sacred. 50

Scholastic criticism of trial by ordeal did not reflect sceptical naturalism or rationalism but rather a new and more rigorous metaphysics. Over the course of the period 1050-1215, the years of early scholasticism, refined abstract speculation created or intensified the diversions that were held to exist between different categories of event. A harder line was drawn between the natural and the supernatural but also, within the natural, between the miraculous and the supernatural. Thus three orders of categories of event came into being: natural, miraculous, and sacramental. 51

These developments culminated in the decision of the Fourth Lateran Council in 1215 of ficially to abolish trial by ordeal by prohibiting the clerical blessing of the proceedings. ${ }^{52}$ It is crucial to understand, however, that the Fourth Lateran's

49 Brown, "Society and the Supernatural: A Medieval Change", p. 143.

50 Bartlett, Trial by Fire and Water, p. 99.

51 Ibid., p. 87.

52 See Bolton, The Medieval Reformation, pp. 110-11. 
decision was in no way merely the result of intellectual and philosophical trends operating in vacuo - rather, developments in theological doctrine stood in a dialectical relation to changes in political reality.

There were three preconditions that had to be fulfilled before the ordeal could be abolished. Firstly, a party within the Church had to be convinced that the practice was wrong. Secondly, this reforming group had to be in a commanding position within the Church - a reforming elite in fact. Thirdly, the administrative machinery of the Church had to be of such a kind that it would respond to direction from the top. The centralization and systematization of the hierarchy, and the growth of effective bureaucracy and delegation in the twelfth and thirteenth centuries were as much conditions for the end of the ordeal as the change of mind of the clerical elite. As an alliance formed between the Roman Church, the reformers, and the leading schoolmen, an alliance reinforced by a common training in Roman-canonical law and common high church or Gregorian attitudes, so this curial-scholastic elite forged and exploited new legal and administrative forms to implement its decisions. There was no decline of the ordeal, it was abandoned. The papal decision was not a belated recognition of a long process of withering away. It was a policy decision which resulted in the abandonment of the ordeal. 53 [...] The decision of the canonists and popes of the twelfth and early thirteenth century determined that the ordeal would be "irrational". They did not abandon it because it was irrational, it became irrational because they abandoned it. 54

Not surprisingly, the sudden abolition of the ordeal proved something of a crisis within medieval jurisprudence; as the ordeal had been devised as a means of securing a decision in those cases where adequate proof was lacking (e.g. heresy and witchcraft), alternative modes were quickly

53 Bartlett, Trial by Fire and Water, p. 100.

54 Ibid., p. 86. 
developed. 55 There followed a widespread move towards the introduction of the Roman and inquisitorial mode of jurisprudence, inquisitio, coupled with torture as "necessary for the functioning of the newly developing inquisitorial procedure especially after the completion of its elaborate theory of proofs. ${ }^{156}$ As the Roman-canonical system of proofs stipulated the suspect's own confession in the absence of more than one corroborating eye-witness account of the alleged crime, there was tremendous pressure to apply torture techniques as a means of extracting confessions in order to secure conviction. 57 This was particularly true with accusations of heresy, which under Roman law was considered to be, like magic, crimina excepta, a transgression that was so heinous, and for which the evidence was of such a problematic nature that it justified the suspension of traditional legal procedures and safeguards. ${ }^{58}$ By the second quarter of the thirteenth century heresy had come to be regarded by canonical courts as the equivalent of treason, labelled as infamous and placed within the same category

\footnotetext{
55 Cf. ibid., pp. 101-2.

56 Ibid., p. 140. By the end of the twelfth century inquisitio had been widely introduced into ecclesiastical courts, enabling them unilaterally to initiate proceedings against suspects simply on the basis of public rumour. Inquisitio was rapidly adopted by secular courts as well, especially within France and by the various communal governments of northern Italy. Given, "The Inquisitors of Languedoc and the Medieval Technology of Power", p. 342 .

57 Bartlett, Trial by Fire and Water, pp. 140-1.

58 Peters, Torture, p. 61. "The ecclesiastical inquisition did not create the inquisitorial process, with torture to secure confession, but adapted it well on in the process of discovering heresy and developing a number of different means to combat it." Ibid., p. 54.
} 
of crimes such as homicide and theft that were subject to severe penalization and required the full hierarchy of proofs. ${ }^{59}$ Greater ecclesiastical concern with the prosecution of heresy, coupled with the Church's growing exasperation with the general reluctance of the secular authorities to process accusations 60 prompted Gregory IX to establish a separate office of inquisitorial examination in 1231 , accompanied by a number of decisive changes in judicial practise ${ }^{61}$ obviously intended to increase the number of convictions. The newly established of fice of the Inquisition, populated by dedicated Dominican clerics usually deficient in formal legal training, coupled with the ever-increasing concern of the religious authorities to intensify their war against alleged representatives of the stereotype of heretical depravity, appears to have encouraged judges to pursue the prosecution of accused heretics in violation of the traditional judicial pp. 110-11.

59 Peters, Torture, p. 53; Hamilton, The Medieval Inquisition,

60 Peters, Torture, p. 64; Kieckhefer, The Repression of Heresy in Medieval Germany, pp. 75-9.

61 Peters, Torture, p. 64. The new personnel of the inquisitions commonly withheld the names and testimonies of witnesses; severely curtailed the legal counsel of the defense; often admitted the evidence offered by otherwise unacceptable witnesses, such as convicted perjurers; relaxed the general rules of evidence, placing much greater weight on the more marginal forms of indicia such as facial expressions or apparently nervous behaviour of the accused; employed a variety of deceptive entrapment techniques, such as placing informers in the cells of the defendants or offering false promises of leniency in exchange for confessions; and establishing a category of degrees of suspicion held against heretics which determined the intensity of procedures employed against them, involving forms of interrogation that were much broader than those prescribed in the inquisitorial procedures for use against ordinary suspects. Ibid., pp. 66-7. 
safeguards guaranteeing the rights of the defendant. ${ }^{62}$

Inquisitorial techniques initially developed for the prosecution of heresy proved equally useful in the investigation of accusations of occult criminality. As Kieckhefer has remarked in relation to those charges of criminal magic brought forth during the first phase of the rise of the witch trials, "the political climate was ideal for fostering the obsession that [officials] everywhere were being attacked through the surreptitious weapons of sorcery." 63 In his classic study "Sorcery, Demons, and the Rise of Christianity: From Late Antiquity to the Middle Ages", Peter Brown argues that there is a close correlation between accusations of employment of ritual magic within court circles and the breakdown of conventional demarcations of traditional lines of power and authority ${ }^{64}$ - a breakdown which the rise of the professional literati to political prominence in the late Middle Ages represented in the most dramatically possible form. ${ }^{65}$ Brown believes that suspicions concerning the practice of sorcery "in

62 Ibid., p. 66.

63 Kieckhefer, European Witch Trials, p. 10.

64 Brown, "Sorcery, Demons, and the Rise of Christianity: from Late Antiquity into the Middle Ages", p. 124.

65 For a discussion of the ways in which emergent administrative elites sought to secure their new-found political status through the monopolization of "textual communities", cf. Murray, Reason and Society in the Middle Ages, pp. 237-44; and Stock, The Implications of Literacy, Part Two. Stock goes so far as to argue that the rise of literary elites was itself inextricable from the historical development of heresy; "From the eleventh century [literate religious] groups began to play the role of laboratories of social organization, attempting both to improve their own communities and to offer a model of betterment to society at large. Heretics and reformers of course 
high places" may be employed like "radio-active traces in an $\mathrm{X}$-ray: where they assemble we have a hint of pockets of uncertainty and competition in a society [...] committed to a vested hierarchy in church and state." 66 If one considers that in fact "beliefs which relate to magic and witchcraft are beliefs about power and the extent to which the individual is prey to them or can manipulate them are the focus of [the] belief system" 67 , then one can easily concede Moore's point:

When the belief in magical powers begins to be accepted by the privileged it is often found to illustrate not "popular" superstition in any general way, but the use of accusations of sorcery in the competition for power, which surrounds the thrones of arbitrary rulers. This is particularly likely to happen when there is rivalry between traditional advisors and new aspirants to influence. 68

differed in their attitudes towards authority and the official church. But their uses of literacy were similar: in particular, both resorted to textual precedents for justifying deviations from what were considered to be merely customary or unwritten ecclesiastical norms." Ibid., p. 88 .

66 Brown, "Sorcery, Demons, and the Rise of Christianity: from Late Antiquity into the Middle Ages", p. 128.

67 Larner, Enemies of God, p. 138.

68 Moore, The Formation of a Persecuting Society, p. 141. Cf. also Edmund Leach, who makes a similar argument: "Legitimate relations are those in which the direction of power flow is compatible with the interests of those who exercise authority in the social system as it is now. Such relationships are modelled on ideas about benevolent interaction between supernatural powers and men; in witchcraft relations just the reverse is true: the power of the witch is seen as a threat to the established order." Leach, Social Anthropology, p. 22; and Mary Douglas: "It follows that if sorcery is available to anyone who wants to acquire it, then we should suppose that positions of political control are also available, open to competition, and that in such societies there are not very clear distinctions between legitimate authority, abuse of authority and illegitimate rebellion." Douglas, Purity and Danger, p. 108. 
The entire political situation appears even more volatile when we contemplate the considerable evidence appertaining to the wide usage of various magical practices throughout higher administrative circles, particularly those relating to the arts of divination such as astrology. 69 Insecurity in high places led to frequent trials of political magic, usually centred on the couriers and servants of the households of noble families who were frequently suspected of having recourse to necromantic textbooks containing explicitly demonic invocations. ${ }^{70}$

By the beginning of the fourteenth century a novel alignment of political configurations had evolved as a precondition that governed the later emergence of large-scale witchcraft persecutions during the second half of the fifteenth century. Accusations of diabolic transgression, drawn from well-established social stereotypes, particularly that of the devil-worshipping heretic, proved a highly expedient tool in the consolidation of the recently acquired political status of the literati, whose very rise to prominence was itself one of the major factors

69 Cf. Peters, The Magician, the Witch and the Law, pp. 112-23. "In an atmosphere of insecurity, unpredictability, and insinuation, the arts of divination and enchantment appeared to possess considerable political value." Jones, "Political Uses of Sorcery in Medieval Europe", p. 674.

70 Cf. Peters, The Magician, the Witch and the Law, p. 123. Peters believes these clerical authors - and owners - of necromantic texts to play a key role in the gestation of the concept of diabolic witchcraft. "These figures, who are very elusive and not always obviously associated with the greater courtiers may be important for other reasons as well; below the level of the high learned magician, and well above the level of the village and urban people accused of magic, they may form an important link between high and low beliefs concerning sorcery." Ibid., p. 137. Cf. also Kieckhefer, Magic in the Middle Ages, Chapter Seven. 
that prompted rising fears of outbreaks of maleficia within the courts of western Europe. Utilizing the pre-given notions of the satanic heretic, the "university men" proved themselves able in fabricating a coherent stereotypical image of, and thereby providing a justification for the judicial prosecution, of the satanic witch. Thus the persecution of the satanic deviant, of which the witch figure was the single greatest example, played a decisively political role. It assisted not only the development of governmental techniques but also the ideological cohesiveness of the administrative elites; truly, it was the "dark underside of the revival of the twelfth century, and as such inseparable from the whole anatomy".71 By utilizing the heritage of stereotypical classification bequeathed by antiquity, university trained clerks were able to construct an entire chain of ideological signifiers upon which they were able to ground their political authority through the persecution of the identifiable deviant groups. ${ }^{72}$ The ideology of satanic deviancy simultaneously served as one of the main justifications for, as well as a primary target of, the employment of the machinery of inquisitorial jurisprudence.

It is this crucial role in both formulating and disseminating the notion of an organized satanic conspiracy of diabolism, established through the rigorous

\footnotetext{
71 Moore, The Formation of a Persecuting Society, p. 140.

72 Ibid., p. 139.
} 
classification of $\frac{\text { th }}{\text { witch as }}$ heretic ${ }^{73}$, that constitutes the true historical importance of the Malleus Maleficarum. I would suggest that a potentially fruitful way of approaching the text is to view it as an example of a "discursive formation", a term used by Michel Foucault in his analyses of the gestations of politically significant forms of textual constructions. Almost the whole of Foucault's enterprise consists of the systematic application of an extreme form of nominalism in the examination of supposedly concrete historical entities. ${ }^{74}$ Central to Foucault's project is his conception of "the discourse", not to be taken as "groups of signs (signifying elements referring to contents or representations)", but rather as a set of "practices that systematically form the objects of which they speak."75 Hence, a particular discursive formation is

made possible by a group of relations established between authorities of emergence, delimitation, and specification. One might say, then, that a discursive formation is defined (as far as its objects are concerned, at least) if one can establish such a group, if one can show how any

73 And, by extension, as crimen magie: see below, Chapter Seven.

74 "Nominalism was more than a methodological or philosophical preference for Foucault. His histories are themselves nominalist histories. They are not histories of things, but of terms, categories, and techniques through which certain things become at certain times, the focus of a whole configuration of discussion and procedure. One might say he offers a historical answer to the philosophical question as to how things are 'constituted'. His answer is in terms not of transcendental conditions of experience, communication, or language, but of the emergence, at specific times, of assumptions common to a scattered body of thought and policy." Rajchman, Michel Foucault: The Freedom of Philosophy, p. 51; Cf. also Michel Foucault: "One needs to be nominalistic, no doubt: power is not an institution, and not a structure; neither is it a certain strength we are endowed with; it is the name that one attributes to a complex strategical situation in a particular society." Foucault, History of Sexuality, p. 93.

75 Foucault, The Archaeology of Knowledge, p. 49. 
particular object of discourse finds in it its place and law of emergence. ${ }^{76}$

For Foucault, what is most significant about a discursive formation is that it is

not the objects that remain constant, nor the domain that they form; it is not even their point of emergence of their mode of characterization; but the relations between the surfaces on which they appear, on which they can be delimited; on which they can be analyzed and specified. ${ }^{77}$

With regards to understanding the general role that discursive formations play within what he called "the archaeology of knowledge", Foucault claims that:

What we are concerned with here is not to neutralize discourse, to make it the sign of something else, and to pierce it through its density in order to reach what remains silently anterior to it, but on the contrary to maintain it in its consistency, to make it emerge in its own complexity. What, in short, we wish to do is to dispense with "things" [...] To substitute for the enigmatic treasure of "things" anterior to discourse, the regular formation of objects that emerge only in discourse. To define these objects without reference to the ground, the foundation of things, but by relating them to the body of rules that enable them to form as objects of a discourse and thus constitute the conditions of their historical appearance. To write a history of discursive objects that does not plunge them into the common depth of a primal soil, but deploys the nexus of regularity that govern their dispersion. ${ }^{78}$

If one substitutes the word "witch" for the word "discursive object" then what one has in effect is an exceptionally succinct description of the Malleus Maleficarum - the text constitutes a group of relations centred around the fabricated "object" of the diabolic witch, a group of relations that are governed

\footnotetext{
76 Ibid., p. 44.

77 Ibid., p. 47.

78 Ibid., pp. 47-8
} 
by the specific rules of late medieval theology, inquisitorial jurisprudence, and, most importantly, the established discursive tradition of the Heretic/Leper. The $\underline{\text { Malleus identifies an object and systematically erects a discursive apparatus }}$ around that object, transforming it into the subject of a particular discursive formation. ${ }^{79}$ The two phenomena - the identification of the object and the construction of a discursive formation which constitutes it as a subject - are in fact inseparable and must be discussed together in any analysis of the conditions governing the historical appearance of the Malleus. 80

It is evident that the Malleus is an outstanding product of the philosophical and theological discourse of "scholasticism" developed in the twelf th century to defend traditional church doctrine against both heretical and heterodox (mis)understanding; "to establish a unified and articulated system of theology, harmonizing statements in Christian thought and in philosophy which seemed to contradict each other"; and "to build up a system of philosophy that

79 For Foucault, a discursive apparatus is never politically neutral - it is a "thoroughly heterogeneous ensemble consisting of discourses, institutions, architectural forms, regulatory decisions, laws, administrative measures, scientific statements, philosophical, moral and philanthropic propositions, in short, the said as much as the unsaid." Foucault, "The Confession of the Flesh", p. 194.

80 "The reading of a text is no longer a question of assessing its coherence and detecting its hidden intents or the interests it betrays. It is to identify the relation which it establishes between a knowledge which it produces and a power which it programmes, it is to evaluate its strategic functioning in a field of forces." Donzelot, The policing of Families, p. 74. 
could stand by itself and could also support the theological system."81

According to Dom David Knowles, the very word itself has "proved insusceptible

of formal definition or description. It is indeed, formally speaking, a meaningless

term." Instead, scholasticism must be understood as a set of operational

procedures:

The term "scholastic" cannot rightly be applied to the content, as opposed to the method, of medieval philosophy; it is essentially a term of method. If by a scholastic method we understand a method of discovering and illustrating philosophical truths by means of a dialectic based on Aristotelian logic, then "scholastic" is a useful and significant term [...] understood as a methodological process "scholasticism" is almost though not quite co-extensive with medieval thought. ${ }^{82}$

Unfortunately, this formulation is of limited utility, as a comprehensive definition of "medieval thought" appears to be just as elusive.

The truth is that [contemporary] research and criticism has shown that medieval philosophy is far from being a monolithic system. Though more homogenous than either ancient or modern thought, it is nevertheless a

81 Artz, The Mind of the Middle Ages, pp. 256-7; E.W. Monter has even described the Malleus as "that ripe fruit of the scholastic method." Monter, "Law, Medicine, and the Acceptance of Witchcraft: 1560-1580", p. 56. Even the very tripartite division of the Malleus reflects its essentially scholastic nature, with its attempt to unify the argumentative structure of the treatise with theological doctrine. "Die Triadenform [of the Malleus] spiegelt also Trinität und - noch allgemeiner - das ontologische Konzept von Beginn, Fortsetzung und Ende, bezieht sich aber auch schlicht auf den Gedanken, daß die Hexerei in diesem Buch in ihren seinsmäßigen Ursprüngen, ihrer Fortentwicklung gezeigt, ihr auch das Ende bereitet wird. Die durchgängige Neigung schließlich, Aspekte in unteraspekte und diese oft nochmals und nochmals in untergeodnete Gesichtspunkte aufzuteilen, findet ihre Analogie im shcolastischen Weltbild: Die Welt, das seiende, ist hierarchsch gestuft in höhere und niedrigere Formen; dem entspricht der Darstellungstil im 'Malleus' genau." Schnyder, "Der Malleus Maleficarum: Unvorgreifliche überlegungen und Beobachtungen zum Problem der Textformen", p. 133.

82

Knowles, The Evolution of Medieval Thought, pp. 87-8. 
tapestry whose design varies both vertically and horizontally. 83

Knowles identifies three characterizing features of medieval scholasticism - the inextricable relationship between philosophy and theology, philosophy serving primarily as a "necessary preparation for and approach to theology as [...] an explanatory and apologetic agent"; a "close dependence upon ancient philosophy, especially as presented by Aristotle, and this philosophy is regarded as a corpus of rational, natural truths which are as ascertainable and valid in their degree as is the body of revelation"; and thirdly, the "method of quaestio ${ }^{84}$ and disputatio which is used throughout not only for purposes of exposition, but also for those of research." 85

83 Ibid., p. 89

84 For a commentary upon the Malleus's exploitation of the political potential of the traditional quaestio, cf. Schnyder, "Der Malleus Maleficarum: Unvorgreifliche überlegungen und Beobachtungen zum Problem der Textformen", p. 138. "Es wird [...] deutlich, wie stark die ihrem Selbstverständnis nach der Wahrheitssuche verpflichtete Form [of the quaestio] hier der ideologischen Beeinflussung dient. Mit Blick aud die jeweilige Sprechsituation kann man festhalten, daB die Auseinandersetzung zweier gleichgestellter Kontrahenten vor einem sachkundigen Publikum in der disputatio (deren Resultat ja ursprünglich die Quästio schriftlich festhielt) durch die Belehrung des stumm zuhörenden Laien seitens des Predigers von der Kanzel herab ersetzt worden ist."

85 Ibid., pp. 89-90. For an extended discussion provided by a nineteenth-century Catholic theologian, cf. also Herbert Grundmann, Die Geschichte der Scholastischen Methode, ch. 1, "[Es] begegnet uns [...] als das Charakteristikum der theologischen Methode das Bestreben, vornehmlich durch Verwertung der Philosophie eine Einsicht in die Glaubenswahrheit zu erzielen. Aus dieser Auffassung des eigentlichen Wesens der scholastischen Methode erklären sich auch die verschiedenen Erscheinungen und Æ̈ußerungen des mittelalterlichen philosophischtheologischen Wissenschaftsbetriebes. Bei dem Bemühen, die übernatürliche Wahrheit dem Denken näher zu bringen, in das Wie und Warum derselben, unbeschadet ihres Geheimnischarakters, eine rationelle Einsicht zu gewinnen, manifestiert sich der Komplex der übernatürlichen Wahrheiten als ein erhabener Organismus von Geheimnissen, es treten 
The interconnection between academic discourse and textual production is readily apparent in the First Part of the Malleus, "Quae ad Maleficium concurrunt: ut sunt, Daemon, Maleficus, et Divina Permissio", where all of the defining characteristics of scholasticism as identified by Knowles manifest themselves in the text's identification of the discursive subject of the witch. The whole of Part One, basically an extensive and highly complex appeal to religious authority, contains no less than 104 references to Scripture. The primary books cited are, in order of frequency, Ecclesiastes, Job, Genesis, Kings, Proverbs, Corinthians, Deuteronomy, Exodus, and Leviticus. The main strategy deployed here, especially with regards to Job, Exodus, and Leviticus, is to base a demonstration of the reality of both satanic intervention and diabolic witchcraft upon a direct appeal to the self-evident authority contained within the Word of God. Kramer and Sprenger even go so far as to take the radical step of declaring it heresy to doubt the reality of maleficium. ${ }^{86}$ Supplementing

tiefe Zusammenhänge und lebensvolle Verbindungen zwischen diesen Wahrheiten zu Tage und regen den Theologen zur Darstellung dieser Zusammenhänge, zur systematisierenden Tätigkeit an. Bei diesem streben nach rationeller Einsicht in den offenbaungsinhalt werden sich auch mannigfache Einwände und Schwierigkeiten auf seiten der vernunft und der Philosophie erheben, es zeigen sich Antinomien zwischen auctoritas und ratio, die behoben werden wollen. Daher die den Scholastikern geläufige Gepflogenheit, Einwände zu erheben und zu lösen, Fragen und Probleme aufzustellen und zu beantworten. Diese systematisierende Tendenz und noch mehr dieses Verfahren, Einwände, Schwierigkeiten zu machen und zu lösen, haben unter dem Einfluß verschiedener äußerer Faktoren in allmählicher Entwicklung auch zur Festlegung einer äußeren Technik und Darstellungsform der wissenschaftlichen Arbeit geführt." Ibid., p.36.

86 Malleus, I, Q. 1, p. 1 [Schmidt, I, p. 1], begins "Utrum asserere maleficos esse, sit ad eo catholicum, quod eius oppositum pertinaciter asserere omnino sit haereticum?" 
these biblical citations are numerous references to many of the major texts of both classical philosophy and medieval theology. As would be expected, Aristotle is the most popular of the ancients, with a total of twenty-four separate references, including citations of De Anima, the Ethics, the Metaphysics, the Physics, the Politics, and De Somno et Vigilia. Other classical authors include Boethius, Cicero, Democritus, Hippocrates, Seneca, and Terence. Even more extensive usage is made out of leading theological works. Numerous references are made to the major figures of the early Church, including Saint Ambrose, Saint John of Chrysostam, Saint John Damascene, Saint Dionysus the Areopagite, Saint Gregory "the Blessed", Saint Isidore of Seville, and Saint Jerome. Among the Church Fathers, however, Saint Augustine of Hippo easily dominates, being one of the most frequently cited authorities in the whole of the Malleus. Altogether, there are a total of forty-five references, the major works including De Doctrina Christiana, De trinitate, the Enchiridion, and, of course, De Civitate Dei, which alone is cited eighteen times. References to medieval scholastic theologians abound as well, including Albertus Magnus, Avicenna, Saint Bonaventura, Duns Scotus, and Peter Lombard. Preeminent among these later medieval scholastics utilized in the Malleus is the magisterial figure of Saint Thomas Aquinas. There are no less than forty-four references to Aquinas in Part One, with an additional forty-three citations in Part Two and four in Part Three. The main texts by Aquinas exploited by Institoris are the Summa Contra 
Gentiles, De Malo, the Commentum in quatuor libros Sententiarum Magistri Petri Lombardi (especially the "Secunda Sententiae"), and the Summa Theologiae, a work cited so frequently as to warrant its being regarded as the main source of the entire theological argumentative structure of the Malleus Maleficarum twenty citations appear in the First Part and sixteen in the Second Part. 87

What is most important to note concerning this formidable array of classical and medieval literature is, however, not so much the actual philosophical and theological content of these texts, but rather the very precise purposes to which they are strategically deployed - form very much takes precedence over content. The whole of the First Part is given over to the discussion of a variety of topics concerning the workings and consequences of maleficium, such as whether children can be fathered by incubi ${ }^{88}$, whether Hexen are truly capable of impeding male procreation ${ }^{89}$, and, most importantly, why it appears that women are more attracted to the lures of witchcraft than men. 90 In order to demonstrate the validity of their three basic operating hypotheses - the necessarily satanic nature of all magical practices, the reality of the threat of diabolic witchcraft, and the sanctioning

87 Malleus, I, c.1-18, passim [Schmidt, I, pp. 1-216].

88 Malleus, I, Q. 3 [Schmidt, I, pp. 41-56].

89 Malleus, I, Q.8, 9; [Schmidt, I, pp. 127-45]. Four.

90 Malleus, I, Q. 6; [Schmidt, I, pp. 92-109]. See below, Chapter 
of all malefic activity by the will of God $^{91}$ - Kramer and Sprenger employ in a rigorously dialectical fashion a series of constrasting opinions and assertions taken from acknowledged philosophical and theological authorities so as to arrive at a comprehensive synthesis ${ }^{92}$, resulting in the emergence of the demonic witch as both a discursive subject and an appropriate object of inquisitorial disciplinary techniques. The Malleus thus both utilizes and perfects the discursive practices established through the publication of previous demonological and anti-heretical texts, including the Formicarius of Johannes Nider (1435), the Flagellum Haereticorum of Nicholas Jacquier (1445), and the Fortalium Fidei of Alfonso de Spina (1459). 93 As Edward Peters has pointed out,

What is striking about the Malleus is its economic use of the quaestio form to bring together elements from all of the diverse sources that had provided elements of the new fifteenth-century beliefs [...] The juxtaposition of these elements in a single, concentrated, tightly argued treatise of considerably greater length than any earlier work really

91 "The phrase 'with the permission of God' recurs throughout the Malleus, and every similar witch-hunting manual, like an involuntary mental spasm afflicting [the] authors whenever inconsistent, nonsensical, or impossible assertations are made. It is employed like some invincible chess piece empowered, in moments of agony, to remove all the opposing pieces from the board." Anglo, "Evident Authority and Authoritative Evidence", p. 21.

92 "Die Quästio, mit ihrem ausführlichen oder wenigstens abkürzenden zitieren von Autoritäten und mit der gedanklichen Auseinandersetzung über Widersprüche und unvereinbar Scheinendes bot sowohl - um moderne Begriffe einzusetzen, - den Rahmen für einen bibliographischen Apparat, wie auch Gelegenheit zu Forschungsbericht, Darlegung eigener und Kritik fremder Positionen. [...] Empirie [i.e. the Malleus' historical accounts] und logische Ableitung aus den autoritativen Zeugnissen der Tradition ergänzen einander", Schnyder, "Der Malleus Maleficarum: Unvorgreifliche Überlegúngen und Beobachtungen zum Problem der Textformen", p. 135.

93 See below, Chapters Five to Seven. 
constituted the basis of the popularity of the Malleus during the next two centuries, [... The text succeeded in] welding together a number of hitherto distinct traditions concerning magic [...] In no other work are theology and law so tightly linked [...] No comparable work approached its comprehensiveness until those of Bodin and Remy, Del Rio and Boguet, at the end of the sixteenth century [...] Indeed, it became the standard reference text for later demonologists and magistrates. 94

It is therefore easy to detect the logical error in Sydney Anglo's argument when he declares that "despite appearances to the contrary [the Malleus] is not an argument but rather a series of assertions masked by an accumulation of authorities and exemplars assembled in disputation form."95 Anglo has here mistakenly defined rational argumentation exclusively in terms of an essentially non-scholastic mode of discourse. By delineating the internal regularities governing the enunciation of statements within the Malleus, one may place the text within the context of the intellectual tradition appropriate to it, the historical a priori. ${ }^{96}$ The Malleus must be understood not solely in terms of the ways in which it allows for the emergence of the witch as a discursive

94 Peters, The Maqician, the Witch and the Law, pp. 174-5.

95 Anglo, "Evident Authority and Authoritative Evidence", p. 19. Cf. Clark: "It is not apparent what criteria of rationality are involved [in early modern demonological treatises], nor how the exegesis of authorities or the use of evidence support the required burden of proof. Since individual steps in the argument are difficult to construe, its overall configuration often remains impenetrable." Clark, "Inversion, Misrule and the Meaning of Witchcraft", p. 98.

${ }^{96}$ Defined by Foucault as "a body of anonymous, historical rules, always determined in the time and space that have defined [in] a given period, and for a given social, economic, geographical, or linguistic area, the conditions of operation of the enunciative function." Foucault, The Archaeology of Knowledge, p. 117. 
subject, but also to that degree in which it represents the witch as an object to be submitted to a series of judicial and disciplinary mechanisms. 97

Within their own premises, Sprenger and Kramer's argument is rigorous and logical, and they carefully marshal "evidence" to support it. Given the premises of God and the Fall they draw out the ontological consequences; what can exist is here determined by theological argument. Given this ontology, then its legal concomitants - in terms of the procedure for the examination of persons to determine whether they are witches - are rigorously derived. 98

Central to Foucault's argument is the assumption of a fundamental correlation between discursive formation and political control, or, rather, between "knowledge" and "power".99 The apparatuses set up to render the subject "knowable" in the very process render the subject controllable, subjugated to an array of power structures.

"Truth" is to be understood as a system of ordered procedures for the production, regulation, distribution, circulation, and generation of statements [...] "Truth" is linked in a circular relation with systems of power which produce and sustain it, and to the effects of power which it induces and which extend it. A "regime" of truth. 100

97 The Third Part of the Malleus is entitled "Ad opus iudiciale, tam in foro Ecclesiastico, quam civili, contra Maleficos, ac omnes haereticos pertinens, XXV. Quaestiones complectens. In quibus regula inchoandi processum iudicii, continuatio et sententiandi modus luculentissime demonstratur."

221.

98 Hirst and Woolly, Social Relations and Human Attributes, p.

99

Foucault, Discipline and Punish, p. 27.

100 Foucault, "Truth and Power", p. 133. 
Concerning the text's political impact upon the course of witchcraft persecutions, the Malleus may thus be viewed as an example of what Foucault refers to as the genealogy of power/knowledge, that

form of history which can account for the constitution of knowledges, discourses, domains of objects, etc., without having to make reference to a subject which is either transcendental in relation to the field of events or runs in its empty sameness throughout the course of history. 101

The precise relationship between the Malleus and the subsequent history of witch hunting is extremely ambiguous, and shall here be sketched only briefly. In my opinion, and contrary to the assertions of historians such as Hugh Trevor-Roper ${ }^{102}$ and Jeffrey Russell ${ }^{103}$, there is no genuine structural continuity underlying the persecution of heretics and witches. Arguments for an apparent historical continuity between the persecution of heretics, especially the Cathars, and witches depend primarily upon a scattering of allegedly contemporary reports of public mass burnings of witches from 1275 to c. $1360^{104}$ - reports which have been proved to be forgeries. 105 What is obvious is that throughout the fifteenth century, with the rise of both the

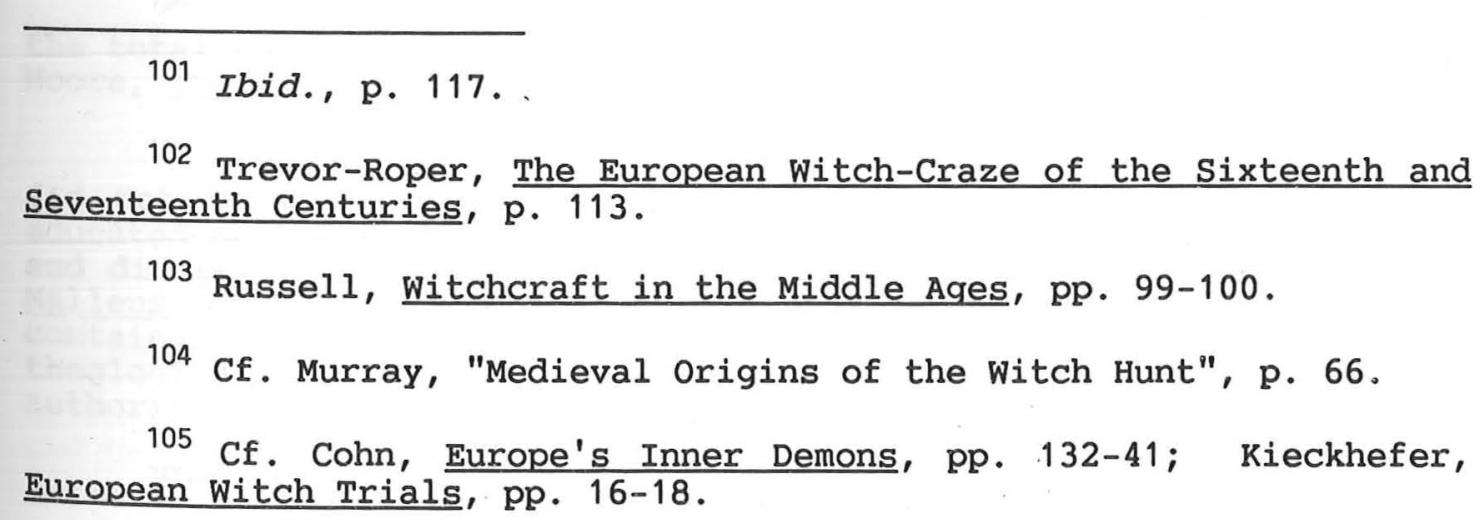


inquisition and the quaestio, and concomitant with the ever wider social dissemination of the stereotype of the satanic heretic, both ecclesiastical and secular authorities increasingly came actively to re-interpret traditional occurrences and accusations of maleficium within the context of the newly forged paradigm of heretical diabolism - a transformative process which provides us with considerable grounds for scepticism concerning the reality of a supposed objective increase in the total number of either witchcraft practices or accusations. 106 The composition and publication of the Malleus is a highwater mark of this trend, the text establishing the precedent of defining maleficium as a separate judicial category of religious and occult transgression, a form of crimen exceptum. ${ }^{107}$ Admittedly, the publishing history of the Malleus provides only highly ambiguous evidence concerning the judicial impact of the text. 108 From 1487 to 1520 , I have identified thirteen editions of the Malleus all but one of them published in Germany. The next edition after that time that I have been able to locate was printed in Venice in 1574, reprinted a

106 In much the same way R.M. Moore strongly doubts an increase in the total number of heretics in the twelfth and thirteenth centuries. Moore, The Birth of Popular Heresy, pp. 1-5.

107 "We must recognize that the cumulative concept of witchcraft did not command instinctive and immediate belief, either among the educated or the illiterate. People had to be told that witches could and did perform the various acts of which they were accused. The Malleus was an appropriate tool in this educative process, since it contained enough information drawn from judicial experience and enough theological citation and argumentation to make it appear authoritative." Levack, The Witch-Hunt in Early Modern Europe, p. 50.

108 See below, Appendix E. 
second time in 1576. Over the next ninety-three years, there were at least eleven printings, in 1580 (Frankfurt), 1582 (Frankfurt), 1584 (Lyon), 1588 (Frankfurt), 1595 (Lyon), 1598 (Fribourg), 1600 (Frankfurt), 1604, 1615, 1620, and 1669 (all in Lyon). The discrepancies in both time and place of publication including a fifty-four year gap in the middle of the sixteenth century - would certainly appear to mitigate against any notion of the Malleus as playing a decisive role as an efficient cause in the rise of the witchcraft prosecutions. However, such a problem only exists in relation to a more reductionist, totalizing explanatory effort which employs a strictly metonymic mode of causality: publication of text $=$ outbreak of Witch Hunt. Within the confines of the notion of historical discontinuity advocated here, with its emphasis on emergent preconditions, any such objection to the historical significance of the Malleus is revealed to be groundless. It is not that the Malleus is without historical value; rather, it possesses value of a different kind, grounded upon a different set of historical configurations and causal relationships.

Such relationships must be located within the outbreak of the Reformation and the subsequent politicization of subjective spiritual practices ${ }^{109}$, the

109 Awareness of the political significance of spiritual "selfdiscovery" were not new to the sixteenth century, but date back at least as far as the central middle ages. Cf. Morris, The Discovery of the Individual: 1050-1200, p. 158. "In the century and a half which included the lives of Gregory VII and Francis of Assis $i$ there did occur [...] a renewed commitment to the examination of the inner life and development of modes of thought about the self and others." Benton, "Consciousness of Self", p. 264. 
concomitant result of the radical reworking of the political relationship between religious devotion and secular power. ${ }^{110}$ With the emergence of the new religious ideologies of the Reformation the ruling elite of Europe had acquired a powerful impetus to maintain political authority through the extensive persecution of religious transgressors, among others now suspect the "cunning folk". As both Catholicism and Protestantism "represented total claims to the whole of Christianity", the splintering of Europe into rival religious factions "allowed religion to function as a focus of loyalty within neighbouring hostile

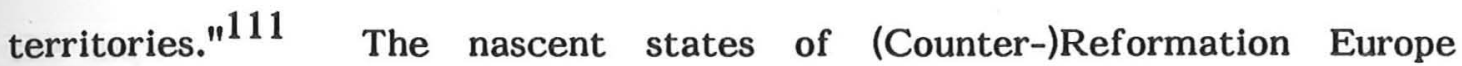
demanded "a new conformity of both formal adherence and inner acceptance expressed in the appropriately ordered behaviour."112 Within the historical context of the sixteenth century, one way in which political regimes could acquire ideological legitimacy was "through the adherence of the populace to the official version of Christianity preferred there"113; ruling elites could

110 "Whether they embraced it or resisted it as a threat, governments everywhere in the empire seized the evangelical movement as a convenient occasion for bringing the church under control and thus achieving dominion over all activities tied to ecclesiastical jurisdictions and the practice of religion. The Lutheran Reformation thus offered unprecedented possibilities of expansion to the early modern state." Strauss, Law, Resistance, and the State, p. 268.

111 Larner, Enemies of God, p. 192.

112 Ibid., pp. 194-5.

113 Ibid., pp. 194-5. 
measure their subjects' political loyalty by their religious conformity. ${ }^{114}$

The new political realities of the Reformation era thus strongly encouraged regimes ruthlessly to intensify the judicial persecution of all alleged adherents to any kind of unofficial system of religious or magical belief or practice ${ }^{115}$ that might prove subversive to the new ideological order. Such concerns are clearly evident in the issuance of contemporary police ordinances, Landes- and Polizeiordnungen. Such measures were in fact inextricable from the entire process of the Reformation, serving as an important source of opportunity for the expansion of state intervention into all spheres of social life via the regulation and standardization of religious belief and conduct. ${ }^{116}$ As Gerald

114 In Christina Larner's colourful phrase, "they marked out the boundaries of their territories not with fences but with churches." Ibid., pp. 194-5; Cf. Delumeau, Catholicism Between Luther and Voltaire, passim.

115 Admittedly, this was not a phenomenon unique to the Reformation: "This drive toward uniformity was not a new undertaking originating in the middle of the sixteenth century. The princely state's endeavour to exert some leverage on its subjects' political and spiritual lives was nearly a century old. It had gathered a momentum that carried the Reformation with it." Strauss, Law, Resistance, and the state, pp. 270-1.

116 "Late sixteenth-century legislation was essentially negative; it prohibited actions and prejudices deemed harmful, and it did so for a negative reason: its major concern was defensive, to protect the inhabitants and the territory from dangerous elements and threats believed to come always from the outside. 'Outside', however, referred either literally to beyond the boundaries of the territory (for example, foreign countries) or to individuals who were outsiders by definition, such as beggars, vagrants, Jews, Gypsies, and dissidents who had become outsiders by virtue of their beliefs or attitudes people such as heretics, criminals, and those believed to be sorcerers, witches, and Anabaptist. The ordinances of that period took it for granted that a prince's true subject, a subject who followed the 'right' ways and 'correct' beliefs, could not be an outsider; thus such a subject could not be an offender against the polity as a whole." Raeff, The Well-Ordered Police State, pp. 167-8. 
Strauss has pointed out,

The proliferation of rules and legislation, which is the characteristic self-expression of the early modern bureaucratic state, aimed at three objectives. It undertook to replace false or undetermined with correct and certain standards of social, political, religious, and moral behaviour; it sought to level diversity and achieve something close to uniformity in the public adherence to these standards; and it tried to counteract the danger arising from men's incorrigible frailties of mind and character by enforcing adherence through supervision, suppression, and where necessary, punitive force. Formulated in less negative terms, the state's political activity, assuming the malleability of human behaviour through habit formation, saw in a fine-meshed network of regulatory commands, the best chance of improving men's performance of public duties and private obligations [...] Hence the mass of statutes, regulating everything and linked to frequent inquisitions to ascertain that the rules were being observed. 117

The staging of such "frequent inquisitions" was the direct result of the of ficial adoption by the state of Roman jurisprudence, a mode of judicial inquiry institutionalized in Germany with the promulgation of the Constitutio Criminalis Bambergensis of 1507 and the Constitutio Criminalis Carolina of 1532, under the direct auspices of Charles V. ${ }^{118}$ Both codices standardized inquisitorial procedures, establishing strict guidelines for the implementation of the quaestio and of torture, thereby allowing them to be employed for the benefit of that "orderly and standardized network of legal and administrative jurisdictions

117 Strauss, Law, Resistance, and the State, pp. 151-2.

118 "Roman law and its learned jurists and lesser attendants were [...] essential agents at the center of the momentum gathered by the new state." Ibid., p. 123 . 
[which] was the heart of the sixteenth-century state."119 The discursive formation of the stereotype of the satanic witch provided by the Malleus, both the result of as well as the grounds for the systematic application of inquisitorial interrogation, may thus be seen as one particular element among a whole range of multi-causal factors affecting the State's greatly increased concern with the persecution of religious and ideological subversion. 120 The composition, production, and distribution of demonological texts such as the Malleus may arguably be seen as one focal point of a much wider process of dissemination of a heavily laden ideological concept of moral and religious deviancy, one that both reflected and actively shaped both "high" and "low" cultural notions concerning

119 Ibid., pp. 124, 142. For a discussion concerning the interrelationship between denominational conformity and social discipline, cf. Schwerhoff, "Rationalität im Wahn: zum gelehrten Diskurs über die Hexen in der frühen Neuzeit", pp. 68-72; "An [... der] These von der Hexenverfolgung als Teil einer allgemeinen, von welticher und kirchlicher obrigkeit getragenen Reglementierungskampagne ist so viel richtig, daß die 'neuen' Herrschaftsmittel dieser obrigkeit, insbesondere auf juristischem Gebiet, eine conditio sine qua non dieser Verfolgung darstellen. Auch läßt sich die Bekämpfung der Hexen zunächst als Teil der inneren Missionierung verstehen, die mit dem magischen Volksglauben radikal Schluß machen wollte." Ibid., pp. 70-1.

120 There is still no single explanation for the dramatic upturn in the total number of witchcraft prosecutions in the second half of the sixteenth century; political control via denominational conflict is merely the single most attractive explanation. Ulrich von Hehl has emphasized, "Inzwischen liegen etliche, aber noch keineswegs flächendeckende Untersuchungen vor, die immerhin zeigen, wie unterschiedlich die Gegebenheiten und Voraussetzungen in den einzelnen Verfolgungsgebieten waren. Es dürfte sich daher empfehlen, Deutungsversuche nicht zu großräumig anzulegen, zumal sich die Fülle neuer Ergebnisse noch nicht zu einem widerspruchfreien Gesamtbild ordnen läßt." Von Hehl, "Hexenprozess und Geschichtswissenschaft", p. 369. 
the social and metaphysical status of the witch figure. ${ }^{121}$ The men and women of (Counter-) Reformation Europe may have accused each other of witchcraft for an almost infinite variety of reasons, but invariably such accusations came to be actively reformulated, of ficially and unofficially, within the established discourse of heretical diabolism - by the beginning of the seventeenth century conceptions of demonic witchcraft, especially the Sabbat, had evolved into the highest symbolic representation of moral, political and social subversion, through the witches' systematic performance of antiritual. 122

121 "Die gelehrte Kultur brachte also entscheidende Elemente in den Hexenglauben ein und bestimmte die Komposition dieser disparaten Elemente zum Gesamtbild des Hexenstereotyps. Mit dem Inquisitionspoze $\beta$, mit standardisierten Interrogatorien und mit der Folter besaß die Obrigkeit zudem ein Instrumentarium, um ihre Weltdeutung 'real' werden zu lassen und jene ambivalente Deutung der Volkskultur, nach der Zauberei auch ohne Teufel möglich schien, auszuschalten." Schwerhoff, "Rationalität im Wahn: Zum gelehrten Diskurs über die Hexen in der frühen Neuzeit", p. 47.

122 "Descriptions of the nature of Satan, the character of Hell and, above all, the ritual activities of witches shared a vocabulary of misrule, that they were in fact part of a language conventionally employed to establish and condemn the properties of a disorderly world [...] The full intelligibility of demonological literature was, in the end, dependent on success in reading into each individual facet of demonism an actual or symbolic subversion of a traditional form of life." Clark, "Inversion, Misrule, and the Meaning of Witchcraft", pp. 110, 118. Cf. also Ginzburg, Hexensabbat, passim. The Malleus itself appears to have anticipated these trends, even if only in a rudimentary fashion: "Et sicut iam mali Christiani has corruptelas imitantur, licet, quod ad lasciviam sint translatea ab eis ad tempora carnispriuij quando cum larvis, et ludis et aliis superstitionibus discurrunt, ita et nunc maleficiae his persuasionibus a Daemonibus, in ipsorum complacentiam circa principium anni, quoad divinum officium et cultum ut festum Andreae, et festa natalia Christi existunt, sua maleficia exercent." Malleus, II, Q.1, c.5, p. 125 [Schmidt, II, p. 73.] 
This is perhaps most directly evidenced by the trial records of the Counter-Reformation period, as it was in the law courts themselves that the dynamic interexchange between literate and illiterate conceptions occurred most directly, resulting in the transformation of original charges of malefic sorcery into accusations of organized devil worship. Comprehensive analyses of existent trial records clearly

reveal two types of witchcraft [...] "the witchcraft of the clerics and judges" and "popular witchcraft". The former incorporates the "crimes" described by the witnesses but interprets them in a satanical context that might be straight out of the demonological treatises. The latter seems to have entirely different intellectual origins, for though it is sometimes contaminated by exposure to the judges' point of view [...] it appears to be rooted chiefly in a popular mentality that is still half pagan. 123

This process of "contamination by exposure to the judges' point of view" was to have decisive cultural impact. Robert Muchembled has laboured to demonstrate that by the middle of the seventeenth century members of the lay populace were initiating highly stereotyped accusations of witchcraft that correspond perfectly with all of the key features of the discursive tradition of scholastic demonology 124 - an indication of the degree to which learned conceptions of demonic deviancy had percolated downwards, with the unlettered classes themselves internalizing and replicating the ideological notion of the satanic

123 Larner, Enemies of God, p. 25.

124 Muchembled, "The Witches of the Cambresis", p. 254. Cf. also Briggs, "Witchcraft and Popular Mentality in Lorraine: 1580-1630", p. 338; Ginzburg, The Night Battles, pp. 99-145. 
transgressor. When considered in regard to the more general political problem concerning the relationship between social control and the identification of deviancy

witch-trials can be seen as a form of cultural and social conflict, in which a literate ruling class tried to bring an illiterate peasantry into conformity with its world view and in the process [...] fundamentally transformed an entire set of popular beliefs. 125

Or, to employ some rather Foucauldian language, one might argue that the general acceptance of the discursive subject of the satanic witch by the lay populace by the seventeenth century signalled the full establishment of a particular network of power/knowledge, in which the subject himself had thoroughly internalized the discourse as a means of both defining and regulating the social behaviour of both his own self as well as that of others. It is tempting to regard the emergence of the diabolic witch within the realm of popular culture as a direct prefiguration of the rise of other subsequent discursive subjects, such as the $\operatorname{madman}^{126}$, the vagabond ${ }^{127}$, the criminal, and the sexual pervert.

A close examination of both the preconditions of the possibility of the emergence of the Malleus Maleficarum as a specific text, as well as the exact

125 Levack, The Witch-Hunt in Early Modern Europe, p. 54.

126 Cf. Foucault, Madness and Civilization, pp. 3-37.

127 Cf. Baumann, Memories of Class, p. 40; Evans, The Making of the Habsburg Monarchy: 1550-1700, pp. 411-13. See below, Chapter Four. 
historical role that the text performed as one precondition for the outbreak of the subsequent Witch Hunt, reveals that no ultimate grounds of origins can be discerned and no one particular theme can be collapsed into and subsumed under another. In a fundamental sense, the preconditions of the Malleus may be seen as recapitulating, in an almost micro-paradigmatic fashion the preconditions of the witchcraft persecutions in general, the Malleus as one particular event in an array of continually shifting power configurations and alignments determining those historically specific incidents of politico-judicial persecution. The threshold of the emergence of the Malleus was itself one particular product of the multifarious causes and effects resulting from the rise of the persecuting society centred around, most crucially, the prosecution and repression of the satanic heretic. The Malleus, one end result of this process, both passively reflected and actively affected a set of inherently self-referential social and judicial practices, through its discursive formations concerning the presence of an object - the satanic witch - providing the means of both identification and eradication. A textual artefact which was easily appropriated by the administrative elites of the newly emergent policing states in ensuring political control through religious and ideological purity - needs that were themselves the of fspring of a highly contingent set of historical conditions - the Malleus assisted in the more general project of simultaneously positing the existence of a specific discursive subject and establishing a power apparatus whose purpose was to 
identify and discipline those very subjects. This, in turn, eventually led to the establishment of a network of power relations on the local and microscopic levels that governed the beliefs and behaviours of large numbers of subjects who identified both themselves and others within the confines of the discursive formation laid out in the text.

This chapter has been assertive rather than demonstrative and deliberately so. My goal has been to provide the reader with a form of orientation to my way of approaching the text and to the particular set of questions which I will put to it. I will now direct my efforts to a more detailed examination of the immediate history leading up to the composition and publication of the Malleus, so as adequately to situate the text in the most precise and material way possible within that historical "field of forces" already alluded to but so far unexamined. 


\section{CHAPTER TWO:}

\section{AUTHOR(S) AND TEXT(S).}

It was during the medieval period, perhaps more than during any other historical epoch, that the notion of the written text as a mirror of God and Nature, the site of a massive effort to collect all facets of learning into an encompassing encyclopedia, attained almost total hegemony over the diverse fields of cultural and literary production. 1 "The structure of the summa or encyclopedia is continuous with the larger Book of medieval culture. It is a continuity motivated by the firm belief that the books of man's making would never come into existence without the Logos spoken by God." ${ }^{2}$ Concurrent with this "logocentric" notion of discursive activity was the equally fundamental emphasis laid upon the concept of authorial identity. As Michel Foucault has indicated, in "the order of scientific discourse, it was, during the Middle Ages, indispensable that a scientific text be attributed to an author, for the author was the index of the work's truthfulness. A proposition was held to derive its scientific value from its author." 3 One cannot but be surprised when encountering the tremendous irony that emerges from a critical examination of the Malleus. The entire background to the production of the text reveals a

\footnotetext{
1 Gellrich, The Idea of the Book in the Middle Ages, pp. 17-28.

2 Ibid., p. 20.

3 Foucault, "The Discourse on Language", p. 216.
} 
fundamental confusion concerning authorial identity, an ambiguity of presence which tends to undermine that very claim to absolute authority, both theological and political, naturally assumed by the "logocentric" scholastic discourse infusing the text. This problem becomes particularly acute when analyzing the documentary evidence pertaining to the authors themselves and their relation to the Malleus. Far from establishing authorial presence, the highly ambivalent and at times conflicting testimony of the material points towards an authorial absence, with the result that the ambivalent literary status of the text clearly reflects the dubiousness of its claim to political authority.

\section{1. Heinrich Kramer (Institoris).}

Virtually nothing is known concerning Heinrich Kramer's youth and early adulthood, including the precise location or even year of his birth. What little evidence there is almost wholly indirect. The register of the general of the Dominican order ${ }^{4}$ cites Kramer as "fr. Henricus Institoris de Sletstaat", indicating that the town of Schlettstadt ${ }^{5}$ in the diocese of Straßburg was

4 All references to Institoris contained within the general register are reprinted in Hansen, Quellen, pp. 365-80.

5 Significantly, Kramer cites an occurrence of maleficium taking place at Königsheim Castle near Schlettstadt, c. 1478. This testimony is almost certainly derived from Kramer's first-hand experience. Cf. 
Kramer's native town as well as his then current place of residence. It is also known that Institoris served as confessor to Freidrich Reiser, the "Bishop of the Waldenses" during the time of his imprisonment prior to his execution in Straßburg in $1458 .^{6}$ Furthermore, in 1485 Georg Golser, the bishop of Brixen, castigated Kramer as having become a senile and childish old man. ${ }^{7}$ It would appear reasonable, then, to concur with Joseph Hansen's judgement that Kramer must have been born within the diocese of Straßburg sometime around $1430 .^{8}$

It is likely that Kramer entered the Dominican house at Schlettstadt fairly early, probably sometime in his mid-teens. We possess testimony from Kramer himself that he visited Rome sometime around 1460, as in II, Q.1, c.10, p. 141 [Schmidt II, p. 110] of the Malleus he mentions having encountered an obsessed priest while journeying to the Eternal City sometime during the pontificate of Pius II. The first detailed account concerning Kramer occurs no earlier than 1474 when he (Sartoris) is entered into the register as a Magister Artium and a lecturer of theology at the priory of Schlettstadt. During this time Kramer appears to have suffered imprisonment for having uttered inflammatory statements during a sermon devoted to Frederick III - on 15 June 1474, the

Malleus, III, Q. 16, p. 251 [Schmidt, III, pp. 103-4].

6 Segl, "Heinrich Institoris: Persönlichkeit und literarisches Werk", p. 116.

7 Rapp, Die Hexenprozesse und ihre Gegner in Tirol, p. 7. See below, Chapter Three.

${ }^{8}$ Hansen, Quellen, p. 380. 
general register records that "Henricus Sartoris" had been released from prison thanks to the intervention of some of his fellow Dominicans. It is probable, on the basis of his later work, the Opusculum in errores Monarchiae ${ }^{9}$, that Kramer's anti-Habsburg stance was the result of the emperor's objection to papal temporalities. 10 Whatever the exact causes underlying the incarceration, the Dominican order rewarded Kramer by appointing him Praedicator generalis of the diocese of Straßburg - a largely ceremonial post that granted him the right to his own place of residence, and bestowed upon him the full powers and privileges enjoyed by an official Inquisitor haereticae pravitatis, nominally only for the diocese of Straßburg but, in fact, covering the entire Dominican province of Teutonia ${ }^{11}$, as the position allowed him to override the authority of all other regional inquisitors. Despite the lack of concrete empirical evidence, it is possible that Institoris was to some extent involved in the witchcraft trials at Heidelberg and the Upper Palatinate during this time. 12

9 Institoris, Opusculum in errores Monarchiae (1499).

10 Hansen, Quellen, p. 381; Segl, "Heinrich Institoris: Persönlichkeit und literarisches Werk", p. 104.

11 Upper Germany and all of the Rhenish territories south of Cologne. Cf. Institoris, Epistola contra quendam Conciliistam Archiepiscopum Crainensem, (1482), p. 1 . p. 137 .

12 Hansen, Quellen, p. 235; Kieckhefer, European Witch Trials, 
There does not appear to be any readily apparent explanation for Kramer's swift rise to prominence. It is possible that Kramer's success was in some way linked to the bitter partisan struggles within the Dominican order following the instigation of the reform movement at the Dominican convent of Colmar around $1400^{13}$ and championed by such prominent ecclesiastical figures as Conradus of Prussia and, significantly, Johannes Nider, the author of the Formicarius. ${ }^{14}$ Even if this suggestion is too narrow in its scope, it is almost certain that Institoris' early career was inextricably bound up with the political struggle over the question of ecclesiastical and papal reform, which was a recurrent issue throughout the whole of the fifteenth century and undoubtedly also tremendously enhanced the papacy's concern with the suppression of perceived religious deviance. ${ }^{15}$

In 1475 Kramer journeyed to Rome to attend the anniversary of the order, and later in that year became embroiled in several court cases. On 1 April 1475 the Prior of the Dominican house in Basel was requested to review Kramer's accusations of assault allegedly perpetrated against his person by the brothers

\footnotetext{
13 Hansen, Quellen, p. 381.

14 Hansen, Quellen, p. 399.

15 "If we need to locate a spark [for the persecution of witches] at least one source is clear: the vigorous drive for reform of the Church in head and members, found throughout Western Christendom in the wake of the Council of Constance." Kieckhefer, Magic in the Middle Ages, pp. 199-200. Cf. also Schieler, Magister Johannes Nider, pp. 39$46,348-54$, for a discussion of Nider's involvement in both the Councils of Constance and Basel and his activity as a prosecutor of
} heretics. 
Burkard Bruckslegel and Jodok Furst. Legal problems notwithstanding, Kramer appears to have remained in Rome until 1479, continuing with his studies until formally receiving the degree of doctor of theology on 13 December 1479 . Although Kramer returned to Germany almost immediately afterwards, there is evidence to suggest that he had managed to acquire a degree of political influence within the curia. On 27 November 1481 Sixtus IV wrote to Institoris instructing him to absolve those men who had been excommunicated by Bishop Ursinus of Theaneus for their tardiness in collecting money for the wars against the Ottomans raised though the sale of indulgences. Such connections to the papacy may have done much to enhance Kramer's status among his brethren, and the following year saw Kramer's election as prior of the house of Schlettstadt. 16

These advances were soon jeopardized by an unexpected turn of events which have fuelled historians' suspicions concerning a reptilian element to Kramer's personality ever since. On 26 March 1482 the order deprived Kramer of both his of fice and his property and demanded his return to Rome. ${ }^{17}$ Then,

16 Hansen, Quellen, pp. 366; Segl, "Heinrich Institoris: Persönlichkeit und literarisches Werk", pp. 105-6.

17 "Magister Henricus Institoris de sletstat inquisitor in provincia Theutonie fuit citatus sub penis gravissimus scl. gravioris culpe, privacionis omnium officiorum, privacionis omnium bonorum et graciarum ac suffragiorum ordinis, privacionis omnium graduum et ipsius magisterii, privacionis conventus ordinis et carceris et excommunicacionis late sentencie et suspensionis a divinis et privacionis omnium sacramentorum ecclesiasticorum, quas penas ipso facto incurrat, quatinus infra novem dies debeat iter arripere et Romam venire ad $R^{m u m}$, omni excusacione semota. Dat. Rome XXVI. marcii. 1482", 
on 2 April 1482, Sixtus wrote to the Bishop of Augsburg with orders to arrest Institoris and to compel him to return money and silverware that he had allegedly stolen following a sale of indulgences. Adroit exploitation of political circumstances and religious tensions, however, enabled Kramer to evade the papal condemnation. On 25 March 1482, Andrea Jamometic ${ }^{18}$, the Archbishop of Craynensis ("Archiepiscopum Crainensem"19) publicly called for a re-convocation of the Council of Basel. The background reasons of this affair remain unclear. Although Jamometic was a close associate of both the Emperor and the Pope, the Archbishop seems to have seriously clashed with Sixtus sometime in late 1480 or early 1481 , possibly because of the former's proGhibelline sentiments. In any event, it seems likely that Jamometic's call for thorough ecclesiastical and papal reform served as an opportunistic and intensely personal political move to undermine the Pope's authority; the Archbishop's threatening action quickly came to serve as the nucleus of a wide-

Reichert, Registrum litterarum Salvi Cassettae, p. 18.

18 A member of a prominent Croatian noble family. He is often erroneously referred to as Zamometic. Petersohn, "Zum Personalakt eines Kirchenrebellen", pp. 3-4.

19 There has been some debate concerning the exact location of this arch-diocese. Jürgen Petersohn convincingly argues that it was most probably situated in northern Albania, along the border with Montenegro. In any event, Jamometic seems to have served only in the capacity of a titular bishop. Ibid., pp. 8-15. 
ranging and highly complex constellation of political and religious forces. 20 Taking what may have been cynical advantage of the papal reaction to this overt threat, Institoris speedily composed a scathing polemical attack upon Jamometic, the aforementioned Epistola contra quendam Conciliistam Archiepiscopum uidelicet Crainensem, composed in Schlettstadt on 10 August $1482^{21}$ which proved itself the most prominent and widely cited of all the anti-Jamometic tracts disseminated at this time. ${ }^{22}$ Having proved himself a dutiful son of Rome, the embezzlement charges against Kramer were quietly forgotten, and on 25 February 1483 the vicar-general Salvus Cassetta appointed Institoris vicar of the priory of Schlettstadt. In September 1482 Cassetta travelled to Basel to direct the struggle against Jamometic, appointing Institoris as the spokesman of the papal cause; at the same time, Institoris was ordered by Bishop Kaspar zu Rhein of Basel to pursue his inquisitorial office within both

20 Cf. Schlecht, Andrea Zamometic und der Basler Konzilsversuch vom Jahre 1482 , pp. 74-84. Schlecht also provides a transcription of Jamometic's written proclamation defending the theological legitimacy of his action in calling for a reconvention of the council, first promulgated on 11 April 1482. Ibid., Appendix, pp. 36-41.

21 Cf. Institoris, Epistola contra quendam Conciliistam Archiepiscopum uidelicet Crainensem. The Epistola was first distributed as a one-page fly-sheet, hammered onto the Rhine Bridge at Basel. Segl, "Heinrich Institoris: Persönlichkeit und literarisches Werk", p. 108. The sheet was probably printed in Straßburg; there was at least one later printing, bearing the same date of composition - 10 August, Schlettstadt -, published at either Nürnberg or Reutlingen. Petersohn, "Konziliaristen und Hexen: Ein unbekannter Brief des Inquisitors Heinrich Institoris an Papst Sixtus IV. aus dem Jahre 1484", p. 132; Cataloque of Books Printed in the xVth Century now in the British Museum, p. 466 .

22 Schlecht, Andrea Zamometic und der Basler Konzilsversuch vom Jahre 1482, p. 78 . 
the town and the diocese of Basel and received a formal episcopal letter ${ }^{23}$ of approval. Despite his open challenge publicly to debate Archbishop Andreas at a university in either Germany, France, or Italy ${ }^{24}$, Kramer's crusading zeal, not surprisingly, waned considerably following his acquittal of charges of theft, so that Cassetta was prompted to remind Institoris in a letter dated 23 April 1483 that, on pain of excommunication, the vicar should take care in reminding the audiences of his sermons that the papal bull denouncing Jamometic and his body of followers was still in full effect. ${ }^{25}$ Responding to such overt pressure, Institoris set about to fulfil a promise first made in the Epistola ${ }^{26}$ to compose an additional treatise against the Bishop, De potestate pape ${ }^{27}$, but

23 This may have served as one of the documents attesting to his authority which Kramer utilized prior to the issuance of the summis desiderantes. Wibel, "Neues zu Heinrich Institoris", pp. 123-5.

24 Institoris, $\frac{\text { Epistola contra quendam conciliistam }}{\text { archiepiscopum uidelicet Crainensem, p. } 7 \text {. }}$
25 "Mag. Henrico, priori conventus sletstatensis et inquisitori
heretice pravitatis, mandatur in virtute spiritus sancti et sub poena
excommunicationis late sententie, quatenus praedicet, bullam primam
contra craynensem et Basiliensis esse in suo robore, et quod obediat
(rev) domino legato et exequatur eius jussa et mandata, prout ipse sibi
iniunxerit." Reichert, Reqistrum litterarum Salvi Cassettae, p. 85 .

26 "[...] in tractatu, quem contra te et tuos articulos erroneos inchoavi et perficere intendo, latius deducam; [...] - Et quin specialem tractatum in hac materia perficere intendo, ad presens plura recitare tibi obmitto". Institoris, Epistola contra quendam Conciliistam archiepiscopum uidelicet Crainensem, p. 7.

27 The evidence we possess concerning De potestate pape is derived from a report given to the pontiff and the college of cardinals by the papal legate Angelo Geraldini concerning the progress of the anti-conciliar campaign within Germany; Geraldini approvingly cites the efforts of "quidam inquisitor heretice pravitatis ordinis prediatorum existens prope Argentinam". Cf. Petersohn, "Konziliaristen und Hexen: Ein unbekannter Brief des Inquisitors Heinrich Institoris an Papst Sixtus IV. aus dem Jahre 1484", pp. 133-4. 
the project appears to have come to naught - no existent copies seem to remain.

Nonetheless, the ecclesiastical authorities appear to have been well pleased

with Kramer's efforts. On 28 October 1483 Pope Sixtus IV issued his anti-

conciliar bull Ad comprimendam quorundam and of ficially cited Institoris to

combat the erroneous belief in the superiority of conciliar authority to the

papacy. $^{28}$ Furthermore, on 31 October Pope Sixtus awarded the priory of

Schlettstadt a sizeable indulgence ${ }^{29}$ as a reward for Kramer's role in

28 Ad comprimendam quorundam is reprinted ibid., pp. 158-60; "Et ut premissa omnia et singula ad cunctorum noticiam possint pervenire, dliecto folio Henrico Institoris ordinis fratrum Predicatorum et theologie professori ac per totam Almaniam superiorem heretice pravitatis inquisitori, de cuius fide, doctrina et probitate fidutiam gerimus in Domino specialem, auctoritate et scientia predictis committimus et mandamus, ut presentes nostras litteras per omnia, de quibus sibi expediri videbitur, loca publicare dictasque conclusiones auctoritate nostra reprobare ed damnare et pro reprobatis, damnatis et erroneis omnibus declarare procuret, dantes sibi harum serie plenam, libream et omnimodam facultatem omnia et singula gerendi, faciendi, exequendi et exercendi, que ad errrorum huiusmodi totalem extirpationem cognoverit expedire, ac districte precipiendo mandantes omnibus et singulis archiepiscopis, episcopis et aliis locorum ordinariis, universitatibus et quibusvis aliis personis ecclesiasticis et secularibus cuiuscumque dignitatis, status, gradus, ordinis vel conditionis fuerint, sub excommunicationis pena, quam quilibet contrafaciens ipso facto incurrat et a qua non nisi a Roman. pontifice et debita satisfactione premissa possit liberari, ne eidem Henrico in premissis per se vel alium seu alios directe vel indirecte quovis quesito colore aliquod impedimentum afferre quomodolibet presumant, quinymo omnes favores et auxilia sibi ac ab eo substituendis, quando reguisiti fuerint, omni mora et consultatione remota realiter prestent, ut sic huiusmodi temerarii et heretici eorum iniquitate damnata confundantur et veritas in suo robore permaneat. Et quia difficile foret presentes litteras ad singula queque loca, in quibus expediens foret, deferre, volumus, quod illarum transumptis manu publici notarii inde rogati subscriptis et sigillo dicti Henrici vel alterius persone ecclesiastice in dignitate constitute munitis ea prorsus fides indubia in omnibus et per omnia adhibeatur, que presentibus adhiberetur, si essent exhibite vel ostense." Ibid., pp. 159-60.

29 "Sane sicut fide digna relatione non sine gravi mentis nostre molestia ad nostram audientiam pervenit, in nonnullis Alamanie partibus, zizanie satore procurante, alique hereses etiam quarundam muliercularum fidem abnegantium ab aliquibius citra temporibus et presertim hodiernis, quibus ille iniquitatis filius et perditionis 
thwarting Jamometic and as a means of subsidizing his efforts in struggling against those perfidos hereticos that infested the diocese of Constance. Th $\mathrm{e}$ highly complex interrelationship between inquisitorial activity and broader ecclesiastical political concerns is well demonstrated by a letter from Institoris to Pope Sixtus, dated 29 February 1484 at Straßburg. In this letter Institoris discusses a number of financial and administrative difficulties encountered in his capacity as prior of Schlettstadt ${ }^{30}$; most noteworthy is the inquisitor's lament regarding the lack of both papal support and guidance in the struggle against malefic heresy.

Post devotissima sanctissimorum pedum oscula, beatissime pater. Scribendi fiduciam et sanctitatis vestre benignitas et fiedi urgens

alumnus Andreas olim archiepiscopus Crainensis in reprobum sensum datus erecta cervice a fide deviavit ac multos, qui antea veri christiani et vere catholici erant, suis falsis illusionibus ad suam perfidam sectam induxit, pullularunt; unde expedit, ut de oportuno remedio provideatur, ne errores huiusmodi in dies invalescant, ad quod necesse est non parva inquisitorum heretice pravitatis contra talia presumentes diligentia." Hansen, Quellen, p. 22. The entire letter is reprinted, ibid., pp. 214. In his letter to pope Sixtus of 29. February 1484, Institoris complains about the revocation of his privileges: "Nam ubi in subsidium inquisitorum ac reparacionem monsterii seu conventus nativi undique ruinosi sanctitas vestra plenariam quandam indukgenciam graciose concessit, subito illam per generalem edicti revocacionem annullavit omnes preter Hohannitarum indulgencias revocando, qua ex causa immanissime mesticie inveni terrorem, tum propter scandalum simplicium omnem de cetero credulitatem ab indulgenciis postponencium, tum propter pauperrimi ipsius conventus desolacionem, qui utique plus quam in duobos milibus Floren. dampnificabitur, quod verum esse sanctitati vestre taliter lacrimosis reserare cupio singultibus." Petersohn, "Konziliaristen und Hexen: Ein Unbekannter Brief des Inquisitors Heinrich Institoris an Papst Sixtus IV aus dem Jahre 1484", p. 124.

30 The letter is reprinted, ibid., pp. 123-6. 
necessitas prebuit, ubi sub trina graciosa audiencia ${ }^{31}$, ut sepius scriberem, clementissime indulsit, sub qua et ea, que sequuntur, reserare cupio flexis autem genibus. Ad pedes namque sanctitatis vestre constitutus ac negocia fidei contra conciliistas ${ }^{32}$ ac quasdam alias hereses, presertim muliercularum quarundam fidem katolicam [sic] erga incubos demones abnegantes ${ }^{33}$, tamquam contra domesticos hostes prosecutus, sanctitas vestra duo prebuit oportuna remedia errores conciliistarum per patentam bullam ${ }^{34}$ condempnando [sic] et alias hereses per ereccionem cuiusdam fraternitatis sub laboribus inquisitorum continue predicancium evellendo. ${ }^{35}$ Verum ubi in execucionem primi

31 This indicates that Institoris met with the pope several times late in 1483, prior to the promulgation of the bull Ad comprimendam quorundam; it seems likely that the granting of the indulgence to Schlettstadt three days later was the direct result of these sessions. Ibid., p. 130 .

32 Like the papal bull Ad comprimendam quorundam Institoris uses the term "concilista als Negativebegriff zur Kennzeichung der Vertreter der radikalen Richtung der spätmittelalterlichen Konzilslehre, die eine grundsätzliche überordnung der allgemeinen Kirchenversammlung über den Papst anstrebten." Ibid., p. 130 .

33 Institoris deviates from contemporary practice in failing to provide a unitary term for "witch" - he employs a descriptive composite phrase instead. He also refrains from making any overt reference to maleficia, instead equating witchcraft exclusively with the denial of the faith through affiliation with the devil. Cf. ibid., p. 135. In this instance, the scholastically established linkage between perceptions of magic and learned notions of heresy is particularly self-evident.

34 A reference to Ad comprimendam quorundam.

35 Little seems to have come of this fraternity largely because of the lack of adequate funding and papal commitment to the sort of persecution of diabolists envisaged by Institoris. Ibid., pp. 138-41. The inquisitor undoubtedly intended the fraternity to endorse the preaching and sermonizing against members of unlearned heresies. "Institoris dürfte es bei seinen planungen [...] vor allem um die Schaffung von Laienkongregationen gegangen sein, die das Vorgehen der Inquisitoren gegen das Hexenwesen organisatorisch, finanziell und emotional unterstützten. Der Gedanke, es könne sich hierbei um eine sanftere, gewaltlose, sozusagen missionarische Form der zeitgenössischen Auseinandersetzung mit dem Hexenglauben gehandelt haben, wäre sicher verfehlt. Diese Fraternitäten soliten letztlich dem gleichen ziel dienen wie der inquisitorische Ketzerprozeß auch, nämlich der Vernichtung des Hexentums wie jeder anderen Häresie. Angesichts der offenen und versteckten Widerstände, die Institoris bei seinen Unternehmungen bis in hohe geistliche Kreise hinein erfuhr, mußte ihm daran gelegen sein, die Trägerschaft seiner Kampagnen zu verbreitern, 
bulla absque defectu sit emanata, unde continuus michi et aliis cooperatoribus labores succrescunt ut pote ad visitandum cunctas universitates, que sub prestito iuramento oppositum servare conantur, concilium videlicet esse super papam etc., ipsum tamen secundum per suam patentem bullam pocius in ridiculum quam in fidei honorem per ipsos correctores bullarum extitit conversum [... $]^{36}$

What is striking about this epistle is Institoris' complaint about the absence of adequate papal endorsement, seemingly in precise contradistinction to that offered in Ad comprimendam quorundam. The crucial point, of course, is that the latter document pertained directly to conciliarism, which was obviously regarded by the papacy as a definite threat to its authority. ${ }^{37}$ These considerations may help us to delineate with greater clarity the exact convergence of diverse political factors underlying the sharp increase in heretic and witch hunting in the middle of the fifteenth century. I would suggest that the (comparatively) increased inquisitorial action against suspected religious deviants was, in fact, a direct continuation by other means of the papacy's more general concern with onslaughts against its authority - onslaughts that were most blatantly represented by recurrent demands for the reconvention of the Council of Basel, coupled with the practical need to engage in some sort of reform. This would also explain the papacy's continual vacillation on the

den Bemühungen der Inquisitoren allgemeine Anerkennung zu verschaffen, seine Vorstellungen von der Existenz und dem verwerflichen Wirken von Hexen zu popularisieren." Ibid., p. 141.
36 Ibid., pp. 123-4.
37 Cf. ibid., pp. 129-44. 
question of the vigorous prosecution of witches, in particular in contradistinction to the heightenend surveillance of spiritual non-conformity in general. ${ }^{38}$ This trend is clearly demonstrated in the divergence pointed out by Institoris himself between his capacity as an opponent of conciliarists - such as Andreas Jamometic - and the extension of his powers and of fices as inquisitor heretice pravitatis to the field of witchcraft and heretical diabolism. It is surely not coincidental that Institoris' rise to prominence should have come about as a result of his polemical assault upon Jamometic; it is equally no surprise that his career as an inquisitorial hunter of witches was beset with political difficulties and marked by recurrent judicial failure.

Kramer's career as a noted witch hunter directly overlapped with his office as persecutor of heretics - in itself a significant development, as the mendicant's own career was one of the primary means through which the discursive transformation of diabolic heretic into demonic witch took place. The earliest documentary material that we possess dates from September 1480 in Augsburg, where Kramer initiated proceedings against a local priest, Johannes Molitoris, canon and Stiftspfarrer of St. Moritz. It is unclear from the existant records whether the proceedings constituted an actual inquisitorial trial or merely a disciplinary order of correction outside the framework of the formal affectibus.

38 See below, my discussion of the Summis desiderantes 
judicial process. Apparently, Father Molitoris had, over a period of ten years, daily administered communion to a select group of women. Institoris regarded this as a periculosus error, suspecting that the women had constituted themselves into an heretical sub-sect along the lines of the Beguines; accordingly, he felt compelled to act against them ex debito officii mei. Rigorously following the stipulations that Nicholas Eymeric had laid out in his Practica officii inquisitoris heretice pravitatis ${ }^{39}$, Institoris appointed the prior of the local Dominican house of St. Magdalene as his assistant and secured the support and participation of the local bishop. 40 As prescribed by inquisitorial ritual, Institoris held forth against the suspected deviants in a public sermon in which he offered inquisitorial dispensation to anyone who supported him and excommunication to his opponents. ${ }^{41}$ Molitoris presented himself before Institoris for a lengthy verbal interrogation which resulted in a series of recriminating scholastic rebuttals. The bone of contention between the two centered on the correct interpretation of Aquinas' De frequentatione sacramenti. Molitoris argued that, since St. Thomas clearly states that the

39 See below, Chapter Seven.

40 This was in accordance with the regulations of the Clementia of 1311. Segl, "Heinrich Institoris: Persönlichkeit und Literarisches Werk", p. 110 .

41 Ibid., pp. 109-10. This was the beginning of a trend to be repeated numerous times throughout Institoris' career as is particularly evident in the proceedings at Ravensburg and Innsbruck. See below, Chapter Three. 
Eucharist was intended to foster brotherly love, repeated observances were not to be prohibited as long as no overt abuse of the Sacrament took place; Institoris countered - somewhat dubiously - that Aquinas' meaning was originally intended to apply only to fellow clerics. The inquisitor then proceeded to declare the administration of daily communion opus supererogatorium and demanded its immediate cessation, citing a long list of ecclesiastical authorities in support of his position, including Augustine, Bonaventura, Gratian, Albertus Magnus, and Thomas Aquinas. ${ }^{42}$ Institoris was loath to abandon his suspicions of heresy even after questioning the women; not able to press for formal judicial punishment, he settled for a public pronouncement - "Ecce pronunc in publico illam communionem illum inhibere". Flagrantly disregarding the inquisitor's authority, Molitoris violated the ordinance on 14 September by resuming daily communion and he even incited his followers to a physical attack against Kramer ${ }^{43}$; altogether a stunning example of the inquisitor's utter lack of local political and judicial support. To further Institoris' humiliation, Molitoris journeyed to Rome later that same year and pleaded his case before the pontiff,

42 The transcripts of the proceedings are found in Koeniger, Ein Inquisitionsprozess in Sachen der täqlichen Kommunion, pp. 39-56.

43 Segl, "Heinrich Institoris: Persönlichkeit und Literarisches Werk", p. 113 . 
an audacious strategy that proved successful ${ }^{44}$, for the curia awarded the zealous priest with an additional parish tithe and granted him the title of papal familiarus.

After this incident, it becomes difficult to trace Kramer's inquisitorial activities with any great precision. From between 25 February 1483, when he received permission from the vicar-general to vacate Schlettstadt at his leisure ${ }^{45}$, until August 1485 , when he took up residence at Innsbruck, there is little evidence pertaining to Kramer's exact movements or location at any given moment. ${ }^{46}$ Any assessment of the Dominican's inquisitorial activities should therefore largely be based upon the internal evidence provided by the text of the Malleus itself. However, the only specific indication that the Malleus provides about the details of Kramer's actions is a rather suspect and very evasive passage in II, Q.1, c.4, in which Institoris is understood to claim that, over the course of a five-year period, he had handed over to the secular

\footnotetext{
44 Zoepfl, Das Bistum Augsburg und seine Bischöfe im Mittelalter, p. 478. It seems likely that in exchange for such generous treatment Molitoris agreed to curtail his celebration of the Eucharist, for, on 8 January 1482, Sixtus officially forbade the priest to offer daily communion. Koeniger, Ein Inquisitionsprozess in Sachen der täqlichen Kommunion, pp. 56-7.
}

45 "Mag. Henricus Institoris, inquisitor ac prior conventus Sletstatensis, habuit absolutionem ab officio prioratus, ita quod dum legerit litteras in capitulo, sit absolutus, alias non. Et nullus inferior potest ipsum absolvere. Et potest recipere fratres non fugitivos, quos iudicaverit utiles conventui. - Mag. idem Henricus fuit factus vicarius in conventu eodem cum plena auctoritate." Hansen, Quellen, p. 370 .

p. 404 .

46 Müller, "Heinrich Institoris, der Verfasser des Hexenhammers", 
authorities for execution no fewer than forty-eight suspected witches, most of them within the diocese of Constance, especially around the city of Ravensburg. ${ }^{47}$ Beyond this account the evidence is unfortunately rather slight. It appears as though Kramer abided in numerous locales, at unspecified times, primarily throughout the dioceses of Basel, Constance, Speyer and Straßburg, including Breisach $^{48}$, Buchel ${ }^{49}$, Enningen ${ }^{50}$, Merßburg $^{51}$, Oberweiler $^{52}$, the Black Forest ${ }^{53}$, Waldshut ${ }^{54}$, and Zabern ${ }^{55}$. It is difficult to arrange these peregrinations into any kind of coherent chronological sequence as Kramer frequently omits to specify the time at which the visitations occurred. Assuming that the work of the composition of the Malleus commenced sometime during 1486, then it appears as though Institoris was

47 See below, Chapter Three.

48 Malleus, II, Q.1, c.2, p. 106; [Schmidt, II, pp. 29-30].

49 Ibid., II, Q.1, c.2, p. 110; [Schmidt, II, pp. 40-1].

50 Ibid., II, Q.2, p. 174; [Schmidt, II, p. 189].

51 Ibid., II, Q.1, c.6, p. 127; [Schmidt, II, p. 78].

52 Ibid., II, Q.1, c.2, p. 110-11; [Schmidt, II, p. 39].

53 Ibid., II, Q.1, c.11, p. 148; [Schmidt, II, pp. 127].

54 Ibid., II, Q.1, c.3, p. 114-15; [Schmidt, II, pp. 49-50].

55 Ibid., II, Q.1, c.13, p. 151; [Schmidt, II, p. 135]. 
present in Reichshafen in $1482^{56}$, Hagenau in $1483^{57}$, in Ravensburg from October to November of $1484^{58}$ as well as in other communities throughout Swabia ${ }^{59}$ presumably at this same time, including Enningen and Merßburg, at Röthenbach in the county of Fürstenbach in the Black Forest in march $1485^{60}$, in Innsbruck from August 1485 to February $1486^{61}$, and possibly in the town of Speyer sometime during 1486.62

Institoris was at first aided in his inquisitorial activities by a series of litterae apostolicae which of ficially designated him as an inquisitor of heretical depravity. However, as these letters apparently completely omitted the exact specifications of Kramer's judicial authority, the types of crimes to be investigated, and the sorts of suspects to be interrogated, local religious and

56 Ibid., II, Q.1, c.6, p. 126 - "Aliquid denique factum in Ruchofen pauciset [sic] vix quatuor annis elapsis contigit"; [Schmidt, II, p. 77-8].

57 Ibid., II, Q.1, C.2, p. 109 - "Patent ex his quae per dioeceses Argentinensem, Constantiensem, et oppidam Haganoae Ravenspurg. acta sunt, vix annis tribus evolutis"; [Schmidt, II, p. 37].

58 Ibid., II, Q.1, c.15, pp. 161-2; [Schmidt, II, pp. 157-60]; see below, Chapter Three.

59 Ibid., II, Q.1, c.13, p. 156; [Schmidt, II, pp. 145-6].

60 Ibid., III, Q.17, p. 254 - "Deservit ad hoc factum, guod in Constantiensi Diocesi tribus annis vix elapsis contigisse fertur"; [Schmidt, III, p. 110].

61 Ibid., II, Q.1, c.12, passim; [Schmidt, II, pp. 128-34].

62 Ibid., II, Q.1, p. 96 - "Sic enim in civitate Spirensi, anno eodem, quo liber est inchoatus"; [Schmidt, II, p. 7]. 
secular of ficials found it easy to frustrate the erstwhile witch hunter. In order to secure irresistible papal approval for his cause Kramer, in conjunction with his fellow Inquisitor haereticae pravitatis for the Lower Rhine, Jacob Sprenger, petitioned Rome for further clarifications of their duties and jurisdiction. ${ }^{63}$ On 5 December 1484, Innocent VIII finally promulgated the Summis desiderantes affectibus, acknowledging both Kramer and Sprenger as inquisitors of heretical depravity for all German archdioceses east of the Elbe river and granting them full papal approval in proceeding against all those who would seek to impede their work. ${ }^{64}$ However, even this resounding proclamation of apostolic support ultimately proved null, for, even with the full authorityr of the Summis backing him up, Kramer was forced to undergo a humiliating series of reversals at the hand of the Bishop of Brixen following the disastrous witch trial at Innsbruck. ${ }^{65}$

The uneven mixture of papal support and intensive local resistance finally prompted Kramer to commence work upon a systematic treatise expounding both the theological nature of witchcraft and the practical judicial problems to be encountered in the identification and prosecution of witches. Originally

\footnotetext{
p. 405 .

${ }^{64}$ So far as can be determined this is the very first documentary evidence attesting to Kramer's working in any way in association with Sprenger. Wetzer-Welte, Kirchenlexicon, VI, 808-10.

65 See below, Chapter Three.
}

63 Müller, "Heinrich Institoris, der Verfasser des Hexenhammers", 
composed and circulated in a manuscript form (now no longer existent), probably in or around the city of Salzburg ${ }^{66}$, the Malleus Maleficarum was first of ficially published in Straßburg sometime in 1487. To lend greater credence to the book's claim to absolute authority, Kramer included the papal Summis of 1484 in the very first edition. Furthermore, Kramer sought to obtain the endorsement of the prestigious theology faculty of the University of Cologne. Despite his alleged affiliations with Jacob Sprenger however, only four prof essors were forthcoming in their support, and even this was highly qualified. Thwarted in the accomplishment of his goals though legal means and apparently without Sprenger's knowledge, Institoris, conspired with the local clerical notary Arnold Kolich in forging a second letter of approbation which was inserted into the otherwise legitimate notary instrument issued on 14 May 1987 and reprinted with every subsequent edition of the Malleus Maleficarum. ${ }^{67}$

The next piece of documentary evidence pertaining to Kramer, appropriately enough, concerns a bitter dispute with his former alleged colleague Jacob Sprenger. On 19 November 1487, the day of his appointment to the of fice of provincial vicar of Teutonia, Sprenger received instructions from the vicargeneral Joachim Turriani to prosecute Kramer for the forging of the notary

66 Müller, "Heinrich Institoris, der Verfasser des Hexenhammers", p. 409. See below.

67 Hansen, Quellen, p. 386. See below. 
instrument. ${ }^{68}$ Turriani's directive, in turn, resulted directly from the earlier efforts of the previous vicar-general Jacob of Stubach in securing Kramer's condemnation for some unspecified offense, most likely forgery. On 22 February 1490, following Sprenger's denunciation of Institoris upon assuming the post of provincial of Teutonia, Turriani proclaimed that

mg. Henricum Institoris omnes et singulas penas et censuras ordinis incurrisse propter multa scandala, que perpetravit provincia. ${ }^{69} \mathrm{Et}$ abdicatur a conventionibus vite communis. Et precipitur presidentibus dictorum conventuum pro tempore existentibus, quod nullus recipiat eum in conventu suo. ${ }^{70}$

Following the initial publication of the Malleus Kramer seems to have withdrawn to the Mosel region for, on 20 March 1488, he issued an apparently illegal dispensation to the citizens of Cochem-on-the-Mosel for having erected a cross on Mount Ediger, claiming that he was empowered to do so by the example set by Sixtus IV who - allegedly in response to a previous request made by Kramer himself - granted dispensations to both individuals and communities which had erected road-side crosses as a means of combatting

68 "M. Jacobo Sprenger priori Coloniensi confirmatur commissio facta iam dudum sibi per provincialem, tunc vicarium ordinis, adversus m. Henricum Institoris inquisitorem." Hansen, Quellen, p. 371.

69 Presumably a reference to Kramer's insidious reputation garnered during the witch prosecutions.

70 Hansen, Quellen, pp. 372-3. 
maleficium. ${ }^{71}$ This patently illegal dispensation almost certainly exacerbated even further Kramer's by now severe difficulties with the ecclesiastical authorities. ${ }^{72}$ Utilizing the personal connections that he had garnered by his previous inquisitorial activities, Kramer was able to secure a temporary abode within the episcopal towns of both Augsburg and Salzburg. There, he seems to have restricted himself primarily to the delivery of public sermons within the local cathedrals. ${ }^{73}$

In spring 1491, Institoris was residing in Nürnberg upon the request of the Rat, assisting them with their burgeoning witchcraft problem; in 1486 two women had been tried for stealing clothes from corpses for ostensibly magical

71 This is almost certainly a spurious claim - it was only after 1666 that papal dispensations were awarded for the erection of Kreuzwegandachten. It is on the grounds of such paltry evidence as Kramer's epistle that the normally sober Joseph Hansen makes the sweeping, and wholly unsubstantiated, claim: "Institoris erscheint mit deren [die Kreuzwegandachten] Einführung in Deutschland in ähnlicher Weise eng verknüpft, wie gleichzeitig sein Kollege sprenger mit der Verbreitung der Rosenkransbruderschaften." Hansen, "Heinrich Institoris, der Verfasser des Hexenhammers, und seine Tätigkeit an der Mosel im Jahre 1488", p. 112. Kramer entertained a long-standing interest, befitting a Dominican realist, in the inherent anti-malefic properties possessed by the Cross, demonstrated by his relation of the anecdote of the road-side crucifix that bled after having been shot with the satanic arrows of an "archer-wizard". Malleus, II, Q.1, C.16, p. 164 [Schmidt, II, p. 164-5].

72 Despite his presence in the vicinity, it does not appear as though Institoris was directly involved in either of the mass witch trials and executions which took place at Metz from June to September 1488 and at Coblenz from 1492 to 1494. Hansen, "Heinrich Institoris", p. 114; Hansen, Quellen, pp. 586-7, 592-4.

73 Hansen, Quellen, pp. 378-8. 
purposes $^{74}$, in 1487 Els Rutzscherin had been condemned for performing herbal magic $^{75}$, and in 1489 Margerete Salchingerin was found guilty by a secular court of a magical crime, so heinous as to warrant her public displayal and expulsion. 76 During that summer, Institoris composed a treatise - a fifty-five folio manuscript in both German and Latin - that addressed the legal concerns and reservations of the Nürnberg magistrates concerning the prosecution of witches. ${ }^{77}$ The manuscript was accompanied by a handwritten vernacular letter by Institoris himself in which he laments his so far largely unsuccessful campaign against unholden.

Ich auch gemerckt hab, das vmb manigerlay vrsach mir nit müglich ist, durch alle Land dem ampt [of inquisitor heretice pravitatis] genüglich zu thun mit meiner person vnd das von Ersten So es gar vngelaublich ist an vil oberkayt, das sölich personen mit name(n) vnholden oder hegksen sein sülln oder das got solich sachen verhengt durch weliche Irrung dy obgenant poßhait zugenumen hat vnd vngestraft an vil enden beliten ist.

74 Kieckhefer, European Witch Trials, p. 143; Kunstmann, Zauberwahn und Hexenprozeß in der Reichstadt Nürnberq, p. 33.

75 Endres, "Heinrich Institoris, sein Hexenhammer und der Nürnberger Rat", p. 209.

76 Hansen, Quellen, p. 587; Kieckhefer, European Witch Trials, p. 144 ; Kunstmann, Zauberwahn und Hexenprozeß in der Reichstadt Nürnberg, p. 44 .

77 That the manuscript was commissioned by the Nürnberg town council is evidenced by an entry in the Ratsverlässe of 18. October 1481, listing a payment issued by Ratsherr Ulrich Grundher; "Doctor Heinrich Kremer prediger ordens seins geschickten pu ${ }^{\circ} \mathrm{chs}$ halb einen danckbrief ze schicken mit sambt etlichen gelt für ein kleyd. [...] mehr $6 \mathrm{fl}$ und $2 \mathrm{fl}$ für zerung". There is another such entry in the Nürnberg Briefbuch, Volume 42, also for 18. October. Endres, "Heinrich Institoris, sein Hexenhammer und der Nürnberger Rat", p. 197. On occasion scholars have regarded this manuscript as simply a vernacular version of the Malleus Maleficarum; cf. Jerouschek, "Der 'Nürnberger Hexenhammer' Heinrich Kramers", passim. 
Auch wo sy gestraft sind worden, do ist grosser mißhandel des Rechtns gebraucht wordn, alzo dann in dem Ersten tail des puchs begriffen ist, Auch vrsach halben, da(s) mir nt müglich(en) ist $\mathrm{zu}^{\mathrm{su}} \mathrm{su}^{\mathrm{o}} \mathrm{ch}(\mathrm{e}) \mathrm{n}$ vnd $\mathrm{zu}$ straffen von der grossen menig der vnholden So die mechtig(e)n schorm haben vnd nit die Armen Als mir den wol begegnet ist. Auch dar umb das mich das alter drügkt vnd nymantz die pürde auf sich nehmen will, sorg vnd forcht halb(e)n. 78

By emphasizing the authoritative legitimacy of his pronouncements the inquisitor also voices his resentment against those canonical experts who have previously offered resistance to him.

[...] Auch schick Ich ewr weißheit [the Mayor and Council of Nürnberg] das $\mathrm{pu}^{\mathrm{O}} \mathrm{ch}$ zu theutsch und Latein, das alle gelertten mügen merck(e)n den grundt päbstli(er) vnd kaiserlich(er) recht Auß den aller diser gerichts handl fliessn ist. 79

Like the Malleus the treatise is divided into three main parts. The first discusses those abuses and/or failures of the law by which unholden can escape punishment and thus thrive. ${ }^{80}$ The second part treats those means by which

78 Ibid., p. 196. Endres provides a transcription of the complete letter; pp. 195-6.

79 Ibid., p. 196. This resentment is also evidenced in the subsequent manuscript. Cf. Endres, "Wahrscheinlich waren diese gelehrten Ratskonsulenten die Hauptgesprächspartner und Kontrahenten des Inquisitors bei seinem Aufenthalt in Nürnberg, denn der gelertten wegen schreibt er sein Buch auch in Latein und greift auf die päpstliche und kaiserliche Autorität zurück als Grundlage für sein Vorgehen gegen Unholden und Hexen. Seine tiefe Abneigung gegenüber den Gelehrten, gemeint sind stets die Juristen und nicht die Prediger, [...] kommt auch im Text selbst mehrfach deutlich zum Ausdruck. So setzt er sich im III. Teil des Buches mit einem Einschub ausführlich mit den gelehrten doctoren auseinander, die meinen, daß es keinen Grund gäbe, gegen Hexen, die unter schwersten Verdacht stünden, vorzugehen und sie zu verurteilen.", Ibid., p. 199.

80 This section consists of six separate articles which criticize: the widespread disbelief in witchcraft and maleficium causing discord among the authorities and the inefficient prosecution of witches; the lawyers' objections against prosecuting witches on the 
magistrates should conduct examinations and trials - the judge is obliged to follow up every denunciation; the interrogation of the accused has to be recorded and take place in the presence of several witnesses; the judge is to follow a select set of guidelines when establishing the circumstances of the reported maleficium; he is fully permitted to use torture as a means of investigation - and advice is provided on how to proceed with the interrogation under torture and how to continue the trial in case a confession could not be obtained from the accused. ${ }^{81}$ The third part of the manuscript subsequently deals with those cases where the accused are highly suspect yet refuse to confess. It distinguishes between three degrees of guilt of the accused, "leicht" - i.e. prophesy, love magic, and various minor forms of supernatural of fense that do not involve an act of hommage to the devil ${ }^{82}$-, "schwer" - i.e. magic that involves a pact with the devil but no explicit heretical abnegation of the Faith

grounds that witches can implicate innocent people in the trials; the general refusal of judges to prosecute suspect unholden despite the fact that this is against papal and imperial law; the release of suspect and denounced unholden in absence of a confession, especially as this practice encourages subsequent maleficia against the witnesses; and the general reluctance of judges to investigate denunciations. Cf. Endres, "Heinrich Institoris, sein Hexenhammer und der Nürnberger Rat", pp. 200-2. Endres comments: "Im I. Teil, in jedem der 6 Artikel, werden die kritischen Argumente der Nürnberger Juristen erkennbar, die am Römischen Recht geschult, sich weigern, auf bloße Denunziation hin, ohne sichere Beweise und sichere zeugen, ein Verfahren wegen Hexerei $\mathrm{zu}$ eröffnen und unter der Folter ein Geständnis zu erpressen oder nur aufgrund von erzwungenen Geständnissen Strafen auszusprechen oder gar zum Tode zu verurteilen." Ibid., p. 202.

81 Ibid., pp. 203-4.

82 Ibid., p. 205, 207. 
and no harmful act of maleficium ${ }^{83}$-, and "schwerster Argwohn" or violenta i.e. magic entailing worship of Satan, destructive maleficia and denial of the Faith, practiced almost exclusively by women. ${ }^{84}$

Although technically a separate work from the Malleus, the manuscript in fact replicates and extrapolates from the fundamental tenets of its predecessor, its only original feature being the way in which it tries to establish a system of gradations of guilt of the accused as a means of increasing the numbers of those liable for execution. 85 Despite what must have been a genuine effort on the part of Institoris the treatise had absolutely no impact whatsoever upon the judicial proceedings in Nürnberg 86 : the town council withheld it from official

\footnotetext{
83 Cf. ibid., pp. 205-6.

84 Ibid., pp. 205-7.

85 "Das $B u^{\circ} \mathrm{Ch}$, das Heinrich Institoris im Auftrag des Nürnberger Rates und für die Nürnberger Ratsherren und Juristen geschrieben hat, zeigt in vielen Punkten und Ausführungen Rückgriffe auf die Papstbulle Summis desiderantis und vor allem auf den Hexenhammer, auf den sogar ausdrücklich verwiesen wird. Darüber hinaus aber ist das $\mathrm{Bu}^{\circ} \mathrm{Ch}$ ein eigenständiges udn selbständiges Werk oder Gutachten zur Problematik der Hexen und des Hexenprozesses, das of fensichtlich gezielt auf Fragen oder Bedenken der Nürnberger Juristen ausgerichtet ist. Die gilt einmal für die Frage, ob es Hexen überhaupt gibt und wie man sie erkennen kann. Zum anderen gilt dies für die Frage, ob allein aufgrund von Denunziationen oder Verleumdungen ein Prozeß eröffnet werden müsse, und schließlich für die Einführung des 'schwersten Argwohns im Herzen des Richters' als legitimes Rechtsmittel, wodurch Zeugenaussagen und sogar ein Geständnis der Angeklagten überflüssig werden. Damit geht Institoris über den Hexenhammer hinaus. Wichtig ist auch die Unterscheidung zwischen 'leichtem, schwerstem und allerschwerstem Argwohn', zwischen Zauberern und Hexen, wobei die Unholden oder Hexen als letzte Stufe mit Teufelspakt und Teufelsbuhlschaft, mit Maleficium und Gottesleugnung unausweichlich als Ketzer mit dem Tode zu bestrafen sind." Ibid., p. 208.
}

86 Ibid., pp. 208-16. 
publication, presumably because of the reluctance of precisely those learned magisterial authorities so despised by Institoris to extend the application of torture and execution to the field of spiritual crime. ${ }^{87}$

Despite his ineffectual performance at Nürnberg Institoris' fortunes took a change for the better, the inquisitor having ingratiated himself with the local clerical community at Augsburg with his open defence of the doctrine concerning the reality of the presence of the Host in opposition to prevalent popular scepticism. ${ }^{88}$ Count Frederick IV of Schauenburg, the acting Archbishop of Salzburg from 1484 to 4 October $1489^{89}$, decided to exploit Kramer's reputation as a major inquisitor by installing him as preacher in Salzburg cathedral (lector ecclesie Salzburgensis), causing the displacement of the official resident Dominican preacher Nicholas Gundelfinger. This, in turn, provoked the vicar-general to issue two directives, one dated 17 November 1493, the other 7 January 1494, both ordering Kramer on pain of excommunication to vacate Salzburg immediately. 90 Frederick, however, wrote back to Turriani and asked that the ordinances be nullified offering testimony to Kramer's great sanctity and popular appeal.

87 Cf. ibid., p. 204-5.

88 See below.

89 Hansen, Quellen, p. 374.

90 It is possible that sprenger was behind both of these pronouncements. Hansen, Quellen, p. 388. 
Preterea annuimus, quod dicti fratres Heinricus et Nicolaus hic predicarunt, ut constare posset, uter eorum in seminando verbum dei populo nostro gratior. Itaque compertum est, eundem fratrem Heinricum sacre theologie doctorem et moribus et vita ac verbi dei seminatione nobis cleroque ac populo civitatis nostre Saltzburgensis fuisse acceptiorem, et idcirco ipsum ad of ficium lectoris (tenetur enim sacras literas hic legere) assumpsimus, ita tamen quod conventui Frisacensi ex humanitate quadam solveret id quod per alios lectores ex eodem conventu assumptos persolvi consuevit, ad quod quidem se voluntarium obtulit. ${ }^{91}$

The vicar-general must have complied with this request, for on 21 November 1495 Rome formally approved a public petition seeking Kramer's registration in the calendar of the monastery of Steier for an annual commemoration service, both before and after his death. ${ }^{92}$

During this time Kramer composed at least two written works. The Tractatus novus de miraculoso eucariste sacramento, quando apparet in forma pueri aut carnis vel sanguis in hostia consecrata, originally published in Augsburg on 5 June $1493^{93}$, was a short - twenty-eight folio - and largely inconsequential work, consisting mainly of a sustained defense of the right of the faithful to worship Hosts which had apparently been miraculously preserved. The background to the composition of this treatise is bound up with a

91 Hansen, Quellen, pp. 374-5.

92 Ibid., p. 390.

93 Cf. Institoris, Tractatus novus de miraculoso eucariste sacramento (1496). No reference to the original publisher is available in this edition, the one that I have worked from. For a discussion, cf. Segl, "Heinrich Institoris: Persönlichkeit und literarisches Werk", pp. 115-16, and zika, "Hosts, Processions and Pilgrimages: Controlling the Sacred in Fifteenth-Century Germany", pp. 27-8. 
controversy concerning the spiritual veracity of the Wunderbarliches Gut, a miraculously bleeding Host preserved at the parish of the Holy Cross of Augsburg, which served as the foundation of a local cult of adoration and a cofraternity. In 1491, the cathedral vicar Bernhard Stuntz delivered a sermon that expressed scepticism concerning the Host, causing a conflict which required episcopal intervention. Bishop Friedrich censured Stuntz but initiated investigative proceedings nonetheless. Institoris, on his part, requested a formal assessment from the theology faculty of the University of Ingolstadt which was received on 2 August 1493 and attested to the legitimacy of the miracle. Following the inquisitor's lead, the bishop requested a second assessment from the theology faculty of the University of Erfurt on 20 December. This was forthcoming on 30 January 1494; the faculty held that the miraculous Host was to be considered genuine if signs of blood and flesh were tangibly present and in a non-corrupted state. Notably, the faculty also stipulated that any sceptical or contrary opinion could not legitimately be considered heretical. On 10 May 1495, the eve of the feast of the Wunderbarliches Gut, Bishop Friedrich publicly proclaimed the decision of the university and announced that the cult of adoration was permissible; Institoris, in a manner by now all too familiar, threatened all sceptics with excommunication on 29 May $1495 .^{94}$

94 Kießling, Bürgerliche Gesellschaft und Kirche in Augsburg im Spätmittelalter: Ein Beitraq zur Strukturanalyse der oberdeutschen Reichststadt, pp. 312-15; Zoepf1, Das Bistum Augsburq und seine Bischöfe im Mittelalter, Vol. 1, pp. 528-9. 
Institoris' second piece, the Tractatus varii cum sermonibus plurimus contra quattor errores novissime exortos adversus divinissimum euchariste sacramentum, published in Nuremburg on 26 January 1496 by Anthonius Koeberger ${ }^{95}$, is an altogether more lengthy (134 folio) and substantial treatise. A collection of thirty-six sermons -although several of these are, in fact, subdivisions of larger sermons - delivered by Kramer at the cathedral of Augsburg, the text is intended to provide fellow preachers with material needed in the instruction of the lay populace in the fight against popular scepticism regarding the Eucharist and the Host. Subdivided into three main sections, which respectively contain eleven, nineteen, and six sermons, the sermons are obviously modelled upon those of Albertus Magnus, Institoris attempting to refashion the Blessed Albert so as to meet the requirements of his own (Kramer's) time. The sermons differ from those of Albert in that each is devoted to an explication of only a small passage from Scripture and ends on a mandatory moral exemplar. The first set of sermons discuss the Last Supper and the establishment of the Sacraments as well as certain exceptional qualities of the Sabbat. All nineteen sermons of the second part are devoted to the miracle of the Eucharist, and the entire treatise ends with an extended

95 The same publisher as for the 1494 Nürnberg edition of the Malleus. See below, Appendix E. 
discussion of the proper reverential means of receiving the Host. ${ }^{96}$ Although primarily devoted to a discussion of the Sacraments, Kramer, significantly, reveals his latent Dominican-Realist predilection for impressing upon the sceptical minds of his listeners a firm belief in both the efficacy of supernatural power in general and in the reality of the threat of demonic magic in particular. Replicating in miniature the main argumentative thrust of the Malleus, Institoris at one point unconditionally declares that the denial of the existence of maleficium is itself tantamount to the heresy of unbelief, that witchcraft has permeated the entire fabric of society, and that the clergy must employ every pedagogical device available to them in order to increase popular awareness of the encroaching diabolic threat. The most notable example of this demonological concern is evidenced in the second part of the sixth sermon of Institoris' Tractatus varii cum sermonibus.

Ex quo etiam traditur necessarium quoddam documentum omnibus Christi fidelibus proponendum. Quod licet magica arte, ut dictum est, sepe fiant dyabolice deceptiones, ut res visibiles vel omnino occultentur vel ut aliter appareant, ut res visibiles vel omnino occultentur vel ut aliter appareant quam sint, non tamen credendeum est, quod omnia magorum aut maleficorum opera, quae iam in temporibus multum habundant, semper praestigiosa delusione fiant, ut videlicet malefici (unholden) non possent nisi imaginarie nocere hominibus, iumentis et terre frugibus et non vera et realia nocumenta inferre. Si quis enim hoc asserere vellet pertinaciter et in defensionem maleficarum, heresim omnino saperet, prout in sermonibus de malficarum operibus ad longum pertractatur per patentem

96 Institoris, Tractatus varii cum sermonibus plurimus, passim; Commented upon in Cruel, Geschichte der Deutschen Predigt im Mittelalter, pp. 537-8; and zika, "Host, Processions and Pilgrimages: Controlling the Sacred in Fifteenth-century Germany", pp. 27-8. 
bullam Innocentii octavi desuper emanatam. Quia enim retroactis temporibus periculosi et indocti predicatores quidem non verebantur in eorum publicis sermonibus ad populum asserere: Tu non debes credere, quod huiusmodi mulieres superstitiose, que vulgariter unholden dicuntur, inveniantur, quasi per eas nocumenta inferantur hominibus, iumentis et terre frugibus per tempestates, sed illa contingunt per alias causas nobis occultas vel per demones dei permissione et nullo modo per maleficas, et cum eis obiiciebatur, quod sepe confesse sunt talia fecisse et propterea incinerate, responderunt huiusmodi indocti predicatores, quod seducte fuerunt per demones, in sompnis putantes se facere, cum tamen non faciebant, et quia per huiusmodi vanam doctrinam malefice semper fuerant defensate et sic continue augmentate, ut vix reperiatur villa, in qua non sit rumor de huiusmodi maleficis, eo quod iudices seculares noluerunt sepe propter huiusmodi falsas quorundam predicatorum assertiones eas punire, ideo periculosissimum est huiusmodi predicare, per que defenduntur et augmentantur, non propter nocumenta temporalia, sed propter contumelias creatori et fidei illatas ab eis, cum ipse malefice fidem habent demonibus abnegare, corpus et animam eis tradere et proprios natos demonibus offerre et plura alia, que in dictis sermonibus continentur horribilia perpetrare. Ideo dicat predicator, quod licet quedam eorum opera delusorie fiant et non vere, non tamen omnia ita fieri estimare oportet; ut delusorie fit, ubi membra virilia auferunt, aut in bestiales formas hominem ttransmutant, aut ubi in somnis vehuntur per longa terrarum spatia, prout loquitur caput Episcopi 26 qu. 5, licet etiam sepe corporaliter et non in somnis vehantur, sicut Symon magus volabat in aëre et plures nigromantici sepe transferuntur; tamen ubi nocumenta inferunt hominibus, iumentis et sepe terre frugibus, hec non prestigiosa arte, sed heu vere et realiter ab eis cooperante demonis malicia, ubi deus talia fieri propter peccataa nostra permittit, perpetrantur. Unde et dicuntur, iuxta Ysidorum 8. Ethymologiarum, ultra omnes alios nigromanticos malefice, vulgariter unholden id est sine pietate homines, dicens: Malefici nuncupantur ob enormitatem scelerum. Hi enim elementa concutiunt, mentes hominum turbant et absque ullo venei haustu sola vi carminum animas interimunt. Vide, si placet, caput Nec mirum 26 , quaestio 5.97

Here we witness once again the essentially dual nature of Kramer's discursive

97 Institoris, Tractatus varii cum sermonibus plurimus, fols. Iii.v.- Iiii.r. 
strategy - the fundamental concepts of scholastic demonology and realist theology are employed within a discursive apparatus as a means of identifying, classifying and thereby exerting power over a politically subversive social category.

The Dominican order now began to appear increasingly inclined towards open displays of favour towards Institoris, perhaps as a direct result of Sprenger's death on 6 December 1495. By 23 August 1496 Kramer had been transferred to Venice on Turriani's behest where he was instructed to head the regional inquisitorial efforts against the outbreak of local heresies concerning the nature of the Sacraments. The Scriptores Ordinis Praedicatorum provide extended documentary evidence of the background to the controversy. Apparently the entire scandal of heretical suspicion erupted shortly after a local peasant had discovered, hidden in the woods, two pyxes containing a number of Hosts, presumably stolen from local churches. The parish priest, to whom the peasant had related his discovery, immediately decided the place to be holy ground and erected a small shrine which soon attracted throngs of the faithful. Angered by this unofficial initiative, the Bishop of Padua ${ }^{98}$ dispatched a group of clerics who destroyed the tabernacle, recovered the Hosts, denounced the parishioners of idolatry and diabolism, and placed under excommunication

98 Jacopo Zeno. Summers, "Introduction to 1928 edition", The Malleus Maleficarum, p. XXXV. 
anyone who offered devotion at the accursed spot. This, in turn, triggered extensive and angry discussions among the laity regarding whether the official sacrament of the Eucharist was in fact the only proper means of venerating Christ's Body。 99

99 Quetif-Echard, Scriptores Ordinis Praedicatorum, pp. 896-7. The only overt reference to a Host miracle in the Malleus is in II, Q.1, c.5, p. 125 [Schmidt, II, pp. 73-4], which purports to relate an actual event, but is very imprecise in detail. "Oppidum, quod nominare non expedit, quia ordo charitatis et rationis imperat et suadet: ubi Malefica corpus Dominicum sumpsit, et declinand subito, ut detestabilis modis est mulieryum, peplum ori adhibuit, et in panniculum Dominicum corpus extrahendo involuit, et in ollam, in qua bufo erat, sic a diabolo informata, proiecit, et sub terra in stabulum prope horreum domus suae occultavit cum aliis plurimus rebus adiunctis, ex quibus sua maleficia exercere habuisset. Sed assistente divina pietate, tantum facinus detectum ad lucem pervenit. Nam sequenti die, merceario quodam, causa sui laboris, propter stabulum iter faciente, vocem quasi cuiusdam infantis eiulantis audivit et quando proprius accessit, usque dum ad pavimentum sub quo olla abscondita erat, pervenisset, tanto clarius audivit, et aestimans infantem aliquem a muliere subtumulatum, scultetum, seu praefidentem accessit, et rem gestam, sua aestimatione a parricida perpetratum narravit, qui cito missis servitoribus ita esse ut ille narraverat, repertum est. Exhumare autem puerum nolebant, sed potius ut custodes a remotis positis, si qua mulier accederet, sano usi consilio attendere haberent. Nec enim Dominium corpus ibi absconditum esse noverant: unde et contigit, ut eadem Malfica locum accederet, et sub pallio aliis occulte cernentibus ollam abscondit. Unde capta er quaestionibus exposita facinus detexit, asserens Dominicum corpus cum bufone fuisse in olla absconditum, ut ex his pulueribus sua ad libitum nocumenta hominibus seu aliis creaturis inferre posset." I believe the town in question to be Enntlibuch in the diocese of Lucerne. See below, Chapter Three. 
In late 1495 or early 1496 Institoris was sent to Venice on the command of vicar-general Joachim Turrani to instigate proceedings concerning the possible abuse of the Eucharist. Operating under the direct auspices of the Doge of Venice, Kramer conducted a series of public debates against representatives of the various disaffected heretical elements; amongst other canonical authorities, the prominent Venetian theological doctor Antonio Pizomannis participated alongside with Kramer. Shortly afterwards Pizomannis commissioned Institoris to compose a polemic against the writings of Antonio Roselli. 100 Roselli, a prominent advocate at the papal court ${ }^{101}$, had, through his authorship of the bull Deus novit of 1433 , emerged as the prominent spokesman of the papal opposition to the demands of the Council of Basel for the limitation of curial authority. ${ }^{102}$ His most notable work, De Monarchia, first published in Venice in 1458 with four subsequent editions also published in Venice ${ }^{103}$, was thoroughly unique in that it sought to reconcile what were at the time two mutually contradictory principles. Although supporting the Pope on the question of the conciliar demands for reform, Roselli was equally

\footnotetext{
100 Segl, "Heinrich Institoris: Persönlichkeit und Literarisches Werk", p. 122 .

101 Eckermann, Studien zur Geschichte des monarchischen Gedankens im 15. Jahrhundert, p. 26 .

102 Ibid., pp. 33-5.

103 Segl, "Heinrich Institoris: Persönlichkeit und Literarisches Werk", p. 122 .
} 
adamant in his advocacy of the need to separate temporal and spiritual power and to regard the authority of both Pope and Emperor equally legitimate each within their own sphere. ${ }^{104}$ The De Monarchia's unique assertion of the dual legitimacy of both papal and secular authority may have been a reflection of its author's personal history of impartial service to both the Pope and the Emperor ${ }^{105}$ and of Roselli's sober recognition of the comparative decline of the power of Rome and the practical need to formulate a workable compromise between the curia and the imperium. ${ }^{106}$ Ironically, as the De Monarchia strove to grant equal credibility to both contesting camps, so it could be despised by polemicists of each persuasion. Despite his support of an absolutely sovereign papacy, Roselli's imperial sentiments were considered so dangerous after the Council of Basel and the renewed fractious debate over temporal and spiritual authority that the De Monarchia was condemned in 1491 by both the Doge and the Venetian papal legate Niccolo Franco. Kramer's services were

106 Ibid., pp. 44-9. "Wenn er [Roselli] den Versuch unternahm, ein politisches System zu entwerfen, in dem beide Mächte gleichzeitig Platz hatten und in friedlichem Beieinander ihren streng getrennten Aufgaben lebten, so war er vielleicht einer von den wenigen Männern an der Kurie, die die damalige Situation besonders deutlich erkannten. Denn es läßt sich nicht leugnen, daß hinter all diesen Theorien ganz realpolitische Erwägungen stecken. Kaiser und Papst vereint schienen imstande, dem Konzil Trotz zu bieten. [...] Diese Frontstellung gegen die demokratischen Ideen der Konziliaristen, die Roselli dem Kaisertum an der Seite des Papsttums einräumt, wird von ihm nie ausdrücklich verkündet, aber es besteht kein Zweifel, daß dies der Sinn des ganzen Traktates ist. Hier liegt der Schlüssel zum Verständnis der Monarchie Rosellis." Ibid., pp. 45-6.
} 
thus actively sought by the Venetian authorities, Institoris having established his reputation in issues concerning the papal plenitudo potestatis following the publication of the Epistola of $1482 .^{107}$ Seizing this opportunity as a means of fulfilling his long-standing promise, first made in the Epistola of 1482, to publish a work concerning the proper relationship between Rome and the Empire ${ }^{108}$, Kramer composed his Opusculum in errores Monarchie, published by Jacobi de Leucho in conjunction with Petri Lichtenstein of Venice in August 1496 and then again on 27 July 1499. Following Ockham, Kramer discusses the question of whether it was the canonist's or the theologian's proper jurisdiction to define the relationship between papal and temporal power on the basis of ecclesiastical doctrine. Institoris comes to the core of Roselli's argument - i.e. the respective autonomy of the Emperor within the secular order - by stressing the intertwinement of the jurisdiction of spiritualia and temporalia and concludes that any secular authority is ultimately dependent upon the papacy. The Emperor is frequently cited as minister pape whose temporal legitimacy is derived exclusively from the curia. Institoris also attempts to establish correlations between Roselli's denial of the legality of the Donation of Constantine and, by implication, the legality of papal temporality with the

107 Segl, "Heinrich Institoris: Persönlichkeit und Literarisches Werk", p. 122 .

108 Institoris, Epistola contra quendam conciliistam archiepiscopum uidelicet Crainensem, p. 6. 
heresy of the Hussites. He finally threatens all of Rosellli's followers with excommunication and calls for the burning of all extant copies of De Monarchia. ${ }^{109}$ That Kramer did not reside in Venice for the whole of this period is evidenced by his having commissioned Provost Wolfgang Haimstoeckl of the monastery of Rohr at Abensberg, on 4 July 1497, to serve as his personal vicar for the diocese of Regensburg and to proceed, with the full papal authority embodied in the Summis, against all suspected heretics by lex multorum. 110

At this late stage in his life Kramer's professional career entered a new phase. On 31 January 1499 Pope Alexander VI designated Institoris, assisted by the Provost of Klosterneuburg, to serve as papal inquisitor and nuncio against the Waldensians, Pickards and members of the Brothers of Bohemia and Moravia, precisely those heretics that Institoris was deemed ideally suited to cope with thanks to his previous "anti-Hussite" treatises of 1495 and 1496. The truth of the matter, however, was far more complex. The Bohemian Brothers first emerged from diverse reform groups within the Hussite movement during the second half of the 1450 s, largely in reaction to the reconciliation between the Bohemian and Roman Churches that occurred in the middle of the century.

109 Institoris, opusculum in errores Monarchiae, passim. Cf. Segl, "Heinrich Institoris: Persönlichkeit und literarisches Werk", pp. $121-3$.

110 It is not known whether Institoris himself participated in the proceedings. Also unknown is the number, if any, of suspects arrested and/or executed. Cf. Riezler, Die Geschichte der Hexenprozesse in Bayern, pp. 97-8. 
Although technically a separate group in close association with the Taborites and the Waldensians, the Brothers were classified by their enemies as Pickardian and Waldensian heretics, and the coronation of Georg von Podebrad of Bohemia in 1460 served as the beginning of a long process of intermittent persecution. 111

The Pope ordered the pair to proceed to Olmütz where they were to coordinate their efforts with Bishop Stanislaus Thurzo, and extended their authority to cover the whole of the German-speaking territories of Bohemia and Moravia. A second papal breve was issued on 5 February 1500 which instructed Institoris to confiscate all copies of the main Waldensian text, the Kopyta, composed by Peter Chelcicky ${ }^{112}$ which allegedly attacked all the fundamental tenets of Catholicism, and to hand over the seized copies to Thurzo for public burnings. Kramer was also empowered to appoint local clerical assistants to preach sermons against the Waldensian error in the native languages of Bohemia. On 11 February 1500 Alexander commanded the vicargeneral to issue several additional decrees in support of Institoris. Seeking to engage the leaders of the Pickards in public disputation, Kramer held a series

111 Machilek, "Böhmische Brüder", p. 1. Machilek provides a succinct history of the movement and its heterodox theological doctrines.

112 The first leader of the dominant sect within the early history of the Brothers, centered at the community of Chelcice in southern Bohemia. Ibid., p. 1 . 
of debates concerning the reality of the presence in the Host throughout the years 1501 and 1502. The most notable of these occurred at the Michaelskloster in Olmütz where, in the presence of King Ladislaus of Bohemia, Kramer confronted Laurenz Krasonicky, the head of the Waldensian community at Leitomischl. This encounter produced no apparent results. On several other occasions, Institoris debated Brother Tuma of Prelouc and the Waldensian layman Wenzel, also known as "the Scribe of Reichenau", a former notary of King Matthias of Hungary. A result from these misguided efforts were two highly polemical treatises, composed by Institoris. The first of these, the Opus perutile sermonum in defensionem sancte Romane ecclesie adversus Waldenses haereticos, a sustained assault upon the Kopyta published on 20 April 1501, was apparently reprinted as the $\underline{\text { Sanctae Romanae ecclesie fidei defensionis Clypeus }}$ adversus Waldensium seu Picardorum haeresim, issued at Olmütz on 20 March 1502. 113 This voluminous work, approximating the size of the Malleus, was intended as merely the first instalment of a series of volumes cataloguing Waldensian errors and to provide a systematic refutation of their heretical doctrines, serving as an encyclopediac summation for the purposes of future

113 There is some debate on this question. Hansen regards the two printings as wholly separate works - Quellen, p. 394 - while Charles Zika has identified them as merely two different editions of the same work. Zika, "Hosts, Processions and Pilgrimages", p. 28. I have examined copies of both editions held at both the Staatsbibliothek in Munich and at the University Library at Cambridge and have discovered no appreciable differences between the two texts. 
scholastic disputations against the regional heresy. ${ }^{114}$ of the total of fortyfive errors listed, the Clypeus discusses only the five most basic from which the other forty are derived including, notably enough, opposition to the legality of witchcraft trials. 115 In general, Bohemian heresy is regarded in eschatological terms, the rise and dissemination of Waldensianism acting as a signifier of apocalyptic imminence. ${ }^{116}$ On the defensive side, more than one hundred pages are devoted to refuting the Waldensian view of the Church of Rome as being a whore of Babylon. 117

Sometime during 1505 , three years after the publication of this final massive work, Institoris died, in either Olmütz or Bruenn, receiving the traditional full commemoration from the Dominican order. It remains unknown whether he played any direct role in the trial and execution ${ }^{118}$ of those six Waldensians burned in the vicinity of the Bohemian village of Taus in 1503.

114 Segl, "Heinrich Institoris: Persönlichkeit und literarisches Werk", p. 125 .

115 Institoris, Sancte Romane Ecclesie Fidei Defensionis Clypeus adversus Waldensium seu Picardorum haeresim, fol. $4 \mathrm{~V}$.

116 "Cur et qualiter he due hereses [Waldensianism and maleficia] iam nouissimis his temporibus ecclesiam diuina permissione inficiunt... Nam fundamentum veritatis clare elicitur ex apocalipsi XII. Erit eius ira magna sciens quia modicum tempus habet id est ante finem mundi maiori seuiet diabollus ira aduersus ecclesiam..." Institoris, Clypeus, fol. $88 r$.

117 Ibid., fol. 75-128.

118 Hansen, Quellen, pp. 392-4; Riezler, Die Geschichte der Hexenprozesse in Bayern, pp. 100-1. 


\section{2. Jacob Sprenger.}

We possess no precise information concerning the date or place of birth of Jacob Sprenger, conventionally regarded as the author of the Malleus Maleficarum. ${ }^{119}$ As the Dominican order received novices from between the ages of fourteen to sixteen, and since we do possess definite evidence that Sprenger entered the Dominican house at Basel in 1452, it seems reasonable to assume that he was born in the vicinity of that city sometime between 1436 and 1438. Sprenger took his vows in 1453 after completing his ordinary years in apparently routine fashion. ${ }^{120}$ He then served as a lecturer in theology in the house until 6 April 1467 when, at the request of the vicar-general Martialis Auribelli, the unlicensed Sprenger was transferred to the Dominican house at Cologne, one of the most prestigious houses in the order, and appointed to the university theology faculty. It is probable that the reasons behind Sprenger's early promotion were identical with those underlying Kramer's rapid rise to prominence - namely, the reform movement in the Dominican order of which the house of Basel, along with the Dominican cloister at Colmar, was a leading

119 Allgemeine Deutsche Biographie, Xxxv, p. 303; Wetzer-Welte, Kirchenlexicon, VIII, pp. 450-1.

120 Hansen, Quellen,. p. 395. 
center. It is likely that Sprenger's transfer to Cologne was one small part of Auribelli's more general plan to integrate the recalcitrant Rhenish territories more closely with the general thrust of the reform. It is significant in this respect that, in 1461 , the Dominican house in Cologne had come out in open support of the reform movement, and that the city's Dominican convent had followed suit in 1465 . The evidence we have concerning Sprenger's professional career strongly points towards an intense personal involvement with and support of the reforming elements within the Dominican order of the Church. ${ }^{121}$

In 1468 Sprenger was selected by the General Capital, convened at Rome, to serve as regent of the formal house of studies at Cologne ${ }^{122}$ as part of his work towards the degree of Master of Theology. In December 1471 Sprenger finally became a Licentiat and, in the following year, succeeded Heinrich Loth of Pforzheim as provost of the house ${ }^{123}$ By 1475 Sprenger had received the degree of Doctor of Theology and in May 1476 he acted as the official representative of the house of Cologne at the convocation of the general capital at Perugia ${ }^{124}$ at which time he succeeded in obtaining for his cloister

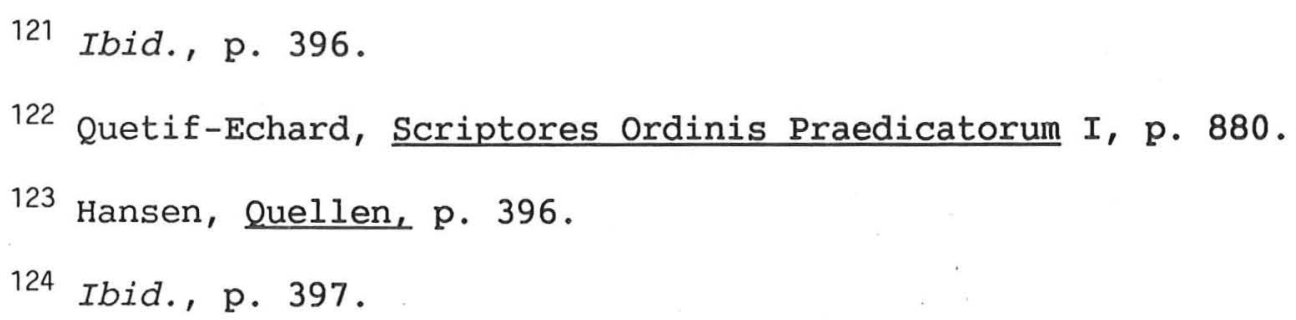


possession of one of the fingers of Saint Anna. ${ }^{125}$ In order to assist the ailing Gerhard of Elten, Sprenger was at that time also elected Provincial for the whole of the Dominican province of Teutonia and subsequently appointed by Sixtus IV as general inquisitor for Germany, especially for the dioceses of Cologne and Mainz. ${ }^{126}$ On 19 december 1478 Sprenger was made professor of the theology faculty at the university and later served as the electoral representative of the faculty during the election of Lambertus de Monte as university rector. On 30 June 1480 Sprenger was elected dean of the theology faculty, an office which obliged him to become involved in several cases of litigation on behalf of the university from 1480 to $1481 .^{127}$ In 1481 Sprenger attended the general capital in Rome. ${ }^{128}$

Sprenger's career as a zealous religious reformer can be delineated with far greater clarity. Sometime during 1474, apparently following a reputed visitation by the Virgin ${ }^{129}$, he became a vigorous champion of the spiritual reform efforts of his teacher Alain de la Roche (Alanus de Rye). Later in that

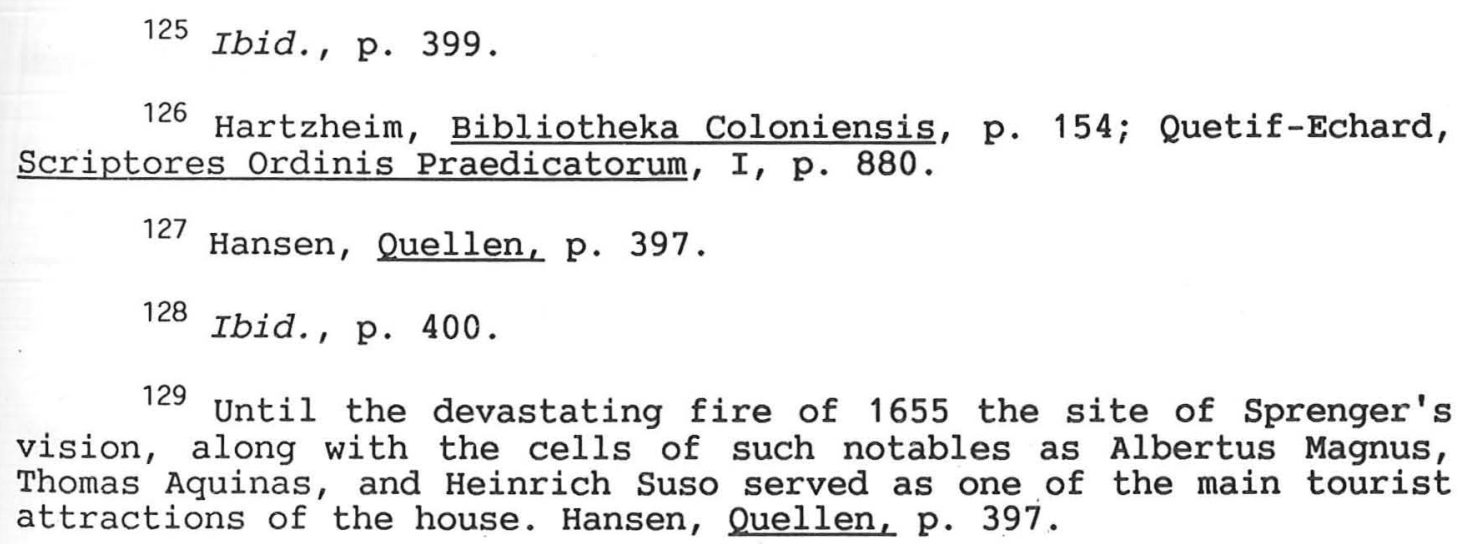


year the city's magistrates and chief burghers, fearful of the armies of Charles the Bold who were at that time besieging the nearby town of Neuss, approached Sprenger for aid in supplicating the Virgin. Sprenger's advice to the council members was not only to honour the Holy Rosary propagated by de la Roche but also to assist in the foundation of a confraternity devoted to the worship of the Mother of God through the ritualistic recitation of the Rosary. On 8 September 1475 , the feast of the Nativity of Our Lady, Sprenger of ficially established the Brotherhood of the Rosary with the full assistance of the Rat and arranged for the consecration of the altar of the rosary in the city's Dominican church, marked by a tremendous public procession through the streets. ${ }^{130}$ The provisions of the fraternity stipulated that every member recite no fewer than three Rosaries every week, amounting to 150 Ave Marias and fifteen Pater Nosters. $^{131}$ Perhaps because of these comparatively light demands, the Rosary Confraternity soon proved itself immensely popular. On 10 March 1476, following the peace between the Duke of Burgundy and Emperor Frederick III, Alexander Numai de Maltesta, Bishop of Forli and legatus a latere to the imperial court for Sixtus IV, formally approved the Brotherhood and rewarded it with several sizeable indulgences. 132 Soon thereafter, Emperor Frederick,

\footnotetext{
130 Quetif-Echard, Scriptores Ordinis Praedicatorum, I, pp. 880-1.

131 Cruel, Geschichte der Deutschen Predigt im Mittelalter, p. 538.

132 Quetif-Echard, Scriptores Ordinis Praedicatorum, I, pp. 880-1.
} 
as well as Empress Eleonore and Crown-Prince Maximilian, along with many of the Empire's other leading dignitaries had themselves enrolled as members, prompting the Confraternity to establish branches in other parts of Germany and the Low Countries ${ }^{133}$ - a task realized through the efforts of Brothers such as Cornelius de Sneckis, Clemens Losow, and Bernardus Lutzenburgensis. ${ }^{134}$ Later that year Sprenger commemorated the establishment of the Fraternity by publishing the Statuten der Rosenkrantz Bruderschafft, printed in Augsburg by Johannes Baemler, which he dedicated to the Holy Mother. ${ }^{135}$ Also in 1476, the master of Saint Severin, one of the most prominent artists of the late period of the School of Cologne, produced a notable work specially commissioned for the altar of the rosary. On the right-hand side of the altar-piece, seeking shelter within the folds of the Virgin's all-encompassing garments were represented many of the most prominent lay members of the Brotherhood, including Frederick, Eleonore, and Maximilian, while on the left, huddled together, were many of the outstanding religious brothers such as the Bishop of Forli and provost Sprenger himself. ${ }^{136}$ This noteworthy honour was soon

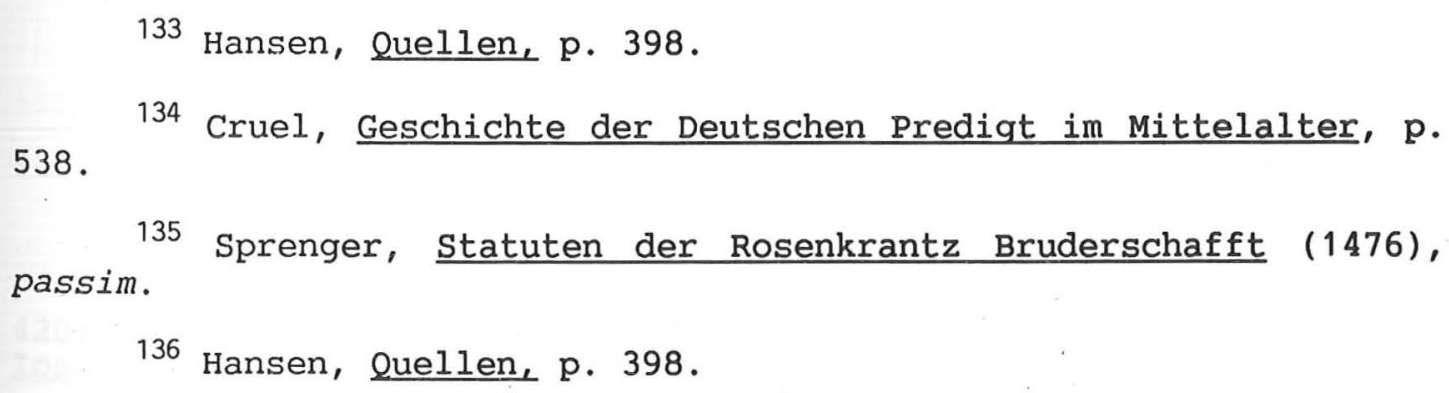


followed by a special papal indulgence granted to Sprenger by Sixtus IV for his exemplary work in establishing the Confraternity. ${ }^{137}$

On 6 June 1474, after having been awarded the vicarage over all reformed Dominican houses within the province of Brabantia, Sprenger proved himself an active leader of the reform movement. He subjected the Dominican cloister at Frankfurt to a complete reform and held extensive visitations at the order's house in Brussels. ${ }^{138}$ He soon gathered a reputation as a formidable opponent of heresy following the trial, on 8 February 1479, of the Franciscan Johann Rucherat of Wesel (Johannes de Weslia/Johann von Wesel), described by Heiko Obermann as a fervent defender of the via moderna. ${ }^{139}$ Esteemed by Melanchthon as one "among those who by their works kept up the continuity of the Church"140, Wesel - a prominent nominalist theologian, professor of theology at Erfurt, preacher at Worms, and commonly referred to as "the Light of the World" and "Master of Contradictions" - was among all else a major critic of the Church, an outspoken opponent of indulgences and openly sceptical about the patristic authority of the Church Fathers as a source of binding theological

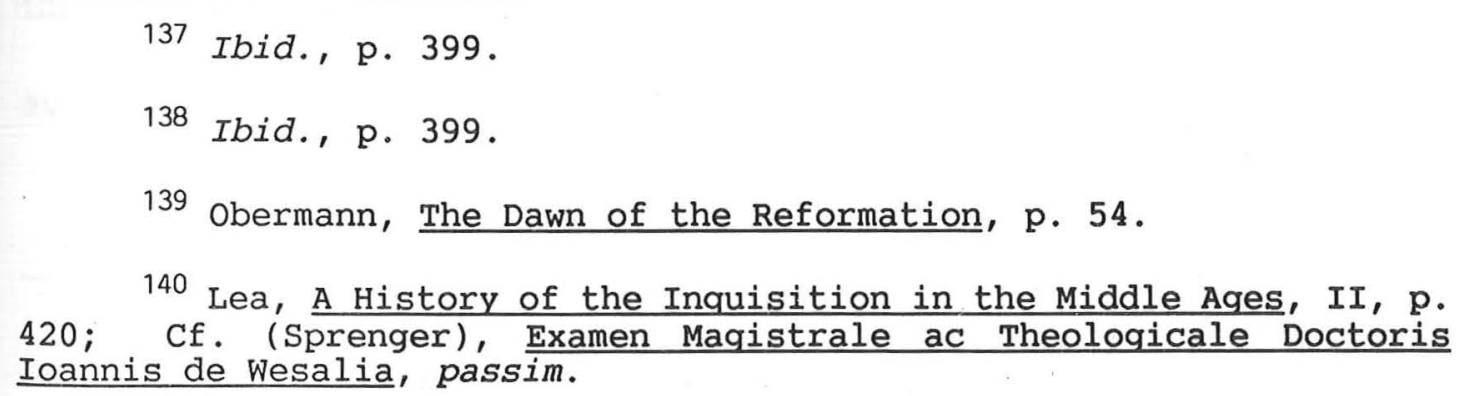


pronouncements. The circumstances surrounding his trial for heresy seemed to be centered on a more general philosophical and political struggle between the Nominalists and the Realist factions in the Dominican community of Mainz. The current Archbishop of Mainz, Diether of Isenburg, was at that time in an extremely tenuous political situation with Rome. In 1463 Diether had publicly denounced the papacy's simonous action in selling his episcopal see to Adolph of Nassau; following Adolph's death, Diether had recovered his former post in 1475 but he was in a state of complete dependence upon Rome for the possession of his office. He was therefore acutely susceptible to curial pressures to comply with the Dominican-Realist demands to censor the noxious Weslia. Succumbing to the papal backing of the mendicants, the Archbishop summoned the general inquisitor of Germany, Gerhard of Elten, as well as the latter's assistant, Jacob Sprenger, to Mainz to conduct a special trial of the Franciscan on charges of heresy. Accompanied by a contingent of Realist theologians from the universities of Cologne and Heidelberg ${ }^{141}$, the two Dominicans, in concordance with the Archbishop, initiated court proceedings that were conducted in blatant violation of customary inquisitorial procedure the court was held in public and attended by numerous ecclesiastical and secular authorities including the Count of Wertheim. The actual trial centered on the

141 There appears to have been only a single Nominalist present. Lea, A History of the Inquisition in the Middle Ages, II, p. 420 . 
suspected heretical content of Wesel's Paradoxa, a work he had referred to numerous times in his sermons and which questioned, among other things, the authority of the Church, the validity of secular law, and the value of dispensations and ritualistic fasting. ${ }^{142}$ After several days of intensive interrogation accompanied by degrading humiliations including imprisonment, Wesel finally recanted on 10 February. His books were burned in a public ceremony, and Wesel himself was sentenced to life imprisonment in the Augustinian monastery at Mainz, where he died in 1481. Sprenger subsequently summarized the proceedings and published the results of the trial in his Paradoxa Johannis de Weslia damnate per G. Elten et J. Sprenger, first published in Mainz in 1479, a short work which even further enhanced Sprenger's standing within the order. ${ }^{143}$ Perhaps as a reward for the services he rendered in the Wesel affair on 19 February 1481 Sprenger was appointed inquisitor haereticae pravitatis for the metropolitans of Mainz, Trier and Cologne as well as for the whole of the Dominican province of Teutonia. ${ }^{144}$

The next recorded instance of Sprenger's reformist efforts comes from Brabantia where he was appointed provost of the Dominican monastery of Brussels on 8 June 1483 and commissioned to supervise the reform of the

142 Cf. (Sprenger), Examen Maqistrale ac Theologicale Doctoris Ioannis de Wesalia, passim.

143 Sprenger, Paradoxa Johannis de Weslia (1479).

144 Hansen, Quellen, p. 400. 
Dominican house at s'-Hertogenbosch, an assignment which occupied him until September. Utilizing his connections with his fellow confraternity member Maximilian I, Sprenger was able to procure imperial support in pressurizing the city fathers to advocate his reform measures, which involved the installation of a new body of superiors in the house including the prior from the pro-Habsburg Dominican monastery at Brussels and the sub-prior from his own house in Cologne. 145 Shortly after this Sprenger seems to have returned to Cologne, on 11 January 1484 during a visitation to that city by the vicar-general Cassetta, Sprenger himself presided over the public raising of the relics of Albertus Magnus, which resulted in the formal establishment of the of ficial cult

145 Hansen, Quellen, p. 399. With regards to Sprenger's reform efforts at $s^{\prime}$-Hertogenbosch, Lene Dresden-Coenders offers the intriguing suggestion that the apocalyptic and demonological concerns which Sprenger reputedly expressed through his sermons at this time may well have exerted a direct influence upon the development of the religious symbolism of Hieronymous Bosch. "Knowledge of Sprenger's contentious actions probably aggravated arguments about the doctrine of witches in $\mathrm{s}^{\prime}$-Hertogenbosch. In any case it is remarkable that it is only towards the end of the century, that is to say after the appearance of the Malleus, that Hieronymous Bosch's diabolic figures lost their traditional character. The symbolism of the customary figures, which was inspired by people or animals, became far more complex. The extensive discussions in the Malleus on hallucinations and demonic apparitions which were used both by devils and by witches readily lent themselves to this." Dresden-Coenders, "Witches As Devil's Concubines: On the Origins of the Fear of Witches and Protection against Witchcraft", p. 72. Although interesting, DresdenCoenders' argument rests upon the assumption that Sprenger must have possessed and publicly displayed an interest in demonology because he was the co-author of the Malleus. It is this very issue, however, which is in doubt. Although not useful for its discussion of Sprenger, Dresden-Coender's essay is helpful in providing a plausible explanation for the artistic development of Hieronymous Bosch - that is, the situation of Bosch's aesthetic production within that same matrix of influences which produced the demonological literature of the Malleus. 
of the saint. 146

As regards to the composition of the Malleus, undertaken at around this time (late 1485 or early 1486), it remains extremely difficult, if not in fact impossible, to specify Sprenger's exact role with any degree of precision. None of Sprenger's published writings display any overt concern with diabolic heresy or crimen magie ${ }^{147}$ and there were few reported incidents of such within the Lower Rhenish territories at this time. Furthermore, and perhaps most important, Sprenger does not actually appear to have been physically present in those regions of Upper Germany at the times in which Institoris was actively engaged in rooting out demonic witches. It certainly seems likely that Sprenger assisted Kramer in petitioning the Curia for an of ficial recognition of their antimalefic activities, resulting in the issuance of several litterae apostolica as well as the Summis. It also appears almost certain that Sprenger was himself responsible for exercising his connections with the imperial chancery as a means of obtaining a royal diploma acknowledging the authority of the Summis. Although there do not seem to be any existent copies of the diploma, it is possible that it was in the traditional format of routine imperial decrees only casually issued by Maximilian, not altogether unlike contemporary "form letters"; that the emperor possessed no exceptional interest in the topic of

146 Hansen, Quellen, p. 400.

147 Cf. Sprenger, Paradoxa Johannis de Weslia; and Sprenger, Statuten der Rosenkrantz Bruderschafft. 
witchcraft is evidenced by the cursory and wholly orthodox references he makes to the subject in Questions Five and Six of the Libri octo quaestionum quas illi dissolvendas proposuit Maximilanus caesar by Johannes Trithemius. ${ }^{148}$ Whatever the exact role played by Sprenger in the composition of the Malleus, it is clear that he violently broke with and fiercely persecuted his alleged partner after Kramer's machinations in the notary instrument affair had fully come to light - a reaction indicating that it was in fact Institoris who was responsible for the forgery and not Sprenger, as has often been alleged. ${ }^{149}$

It appears then that Sprenger's career as a prominent and tireless reformer of the Dominican mendicants largely overshadowed his reputation as a prosecutor of witches - for which there is, in fact, next to no available empirical evidence. Over the next two years Sprenger transversed virtually the whole of Teutonia in the exercise of his inquisitorial duties. In 1486 he presided over the provincial capital at Nuremburg in the absence of provincial Jacob of Stubach, who was in Rome for the duration of the year. On 19 November 1487, following Stubach's retirement, vicar-general Cassetta appointed Sprenger

148 Trithemius, Liber octo questionum, quas illi dissolvendes proposuit Max. Caesar, (1515), Q. V "De reprobis maleficarum" and $Q$. VI "De potestate maleficarum"; Hansen, "Der Malleus Maleficarum, seine Druckausgaben und die gefälschte kölner Approbation vom Jahre 1487", pp. 144-5; cf. Arnold, "Hexenglaube und Humanismus bei Trithemius (1462-1516)", passim.

149 Fehr, Deutsche Rechtsgeschichte, p. 244. 
provincial vicar. ${ }^{150}$ This was followed by Sprenger's election to the of fice of provincial on 8 May 1488 and a subsequent extensive series of visitations throughout Germany - at Frankfurt in Easter 1489, during the provincial capital at Worms in 1490, and at the houses of Speyer, Weisenburg, and Schlettstadt, all notorious locales of anti-reformist sentiment. In May 1491 Sprenger chaired the Provincial Capital in Aachen; in February 1495 he oversaw the reform of the Dominican cloister at Louvain; and on 10 May 1495 he supervised the provincial capital at Bamberg.

Sprenger's zeal in pursuing the ecclesiastical reform seems to have engendered deep-rooted resentment among a substantial portion of his brethren, the great majority of whom actively resisted the reform movement. On 23 April 1495 Pope Alexander VI addressed a letter to Johannes of Becca and Anthony Wellen, both Dominican preachers active within Teutonia, ordering them to remove Sprenger from the of fice of provincial. ${ }^{151}$ However, on 20

150 Hansen, Quellen, p. 401.

151 "Accepimus non sine animi nostri perturbacione, quod dilectus filius Jacobus Sprenger, prior provincialis provincie Theutonie secundum morem fratrum ordinis Predicatorum, non caritatis, pacis et concordie amator sed dissensionum et discordiarum inter fratres, domos ordinis et provincie predictis seminator multas discordias et dissensiones in pluribus domibus ordinis et provincie huiusmodi seminavit ac quadam animi superbia et elacione ductus non, que ad humilitatem et concordiam pertinent, sed in plures fratres domorum predictarum crudeliatem et acerbam vindictam exercere non veretur, ex quo plures ex eisdem domibus in magna perturbacione existunt. [...] quatenus de premissis vos diligenter informetis, et si per informacionem huiusmodi reppereritis, eundem Iacobum ab officio provincialatus dicte provincie auctoritate nostra amoveatis perpetuo realiter ab eodem ac alium verum, timoratum, doctum et expertum, donec alius prior provincialis dicte provincie per dicti ordinis fratres juxta illius regularia instituta electus et confirmatus fuerit, eundem 
November 1495 Pope Alexander abruptly reversed his decision on the grounds that the previous accusations against Sprenger which he had received were in fact baseless.

Cum autem ex litteris dilectorum filiorum capituli provincialis dicte provincie nobis constiterit, premissa nobis exposita minus vera fuisse, et pro illorum parte humiliter supplicatum, ut omnia in pristinum restituere aliasque in premissisopportune providere de benignitate apostolica dignaremur, nos igitur huiusmodi supplicacionibus inclinati vobis auctoritate apostolica committimus ac mandamus, ut ad dicti brevis execucionem quo quomodo ulterius non procedatis. ${ }^{152}$

This rather opaque dispute over Sprenger's fitness to hold office was quickly rendered void by the provincial's sudden death on 6 December 1495 while residing at the Dominican convent in Straßburg. 153

Although posthumously eulogized by the Dominican house of Cologne, Sprenger did not receive the official commemoration from the university, the Seelenmesse, that was due him according to his status as a prominent member of the theology faculty. Although it is a distinct possibility that Sprenger's distance from Cologne at the time of his death may have prompted the university officials to forego the customary services, the most likely explanation for this perplexing omission lies in the fact that the rector of the university at

nostra auctoritate deputetis eique omnia, que de jure vel consuetudine ad provincialem dicte provincie pro tempore existentem pertinent, eciam quoad visitacionem dictarum domorum et in illis pacem et concordiam apponendam procuret, auctoritatem et potestatem dicta nostra auctoritate concedatis." Reprinted in Hansen, Quellen, pp. 376-7.

152 Reprinted ibid., p. 378.

153 Ibid., p. 402. 
that time, Thomas de Scotia, was one of those professors of theology whose name had been forged in the bogus letter of approbation, and who almost certainly held Sprenger personally responsible for the incident. ${ }^{154}$ An added irony was that although Sprenger received great acclamation for his work in prompting the rosary prayers and meditations ${ }^{155}$ it was his supposed collaboration with Heinrich Institoris in compiling and composing the Malleus Maleficarum, the work of a man whom Sprenger had repeatedly opposed throughout the latter part of his life, that served as the main grounds of his remembrance in the Dominican order. 156

154 See below.

155 Cf. e.g. Leander Albert (1516) "Jacobus Sprenger praefectus olim provinciae Theutonicae, sanctissimum rosarum ubique circumferens", cited in Hansen, Quellen, p. 404.

156 Hansen, Quellen, p. 403. 


\section{3. Authorial Identity within the Malleus.}

One of the most puzzling features of the Malleus is the apparent absence of a clearly discernible authorial presence or identity. ${ }^{157}$ Any reflexive references to the author(s) within the text itself are wholly impersonal and actually contribute to anonymity. There are two explicit references to the authors. The first occurs in II, Q.1, c.3, p. 112 [Schmidt, II, p. 44] when the text declares "et licet duo simus hunc tractatum scribentes unus tamen ex nostris saepissime tales vidit \& reperit." The second is located in II, Q.1, c.4, p. 121 [Schmidt, II, p. 65], where the text attests to the validity of the report of the attempted malefic seducation of a virgin in Straßburg ${ }^{158}$-"[...] prout in terra nativitatis unius ex his Inquisitoribus (cum duo simus hoc opus colligentes) contigit."159 The majority of self-referential comments, however, come to

157 Schnyder and Worstbrock, "Institoris, Heinrich OP", 410. The researcher's task is not facilitated by the author(s)'s propensity for making specious claims. II, Q.1, p. 95 [Schmidt, II, p. 5] relates Peter of Bern's efforts to arrest the wizard Stadlin. Although the account is taken directly from Nider's Formicarius - v. c.4, p. 358 that text is not cited, the Malleus' author(s) subtly endeavouring to present the event as personal experience - "Sed et plura, quae nobis inquisitoribus in officio inquisitionis laborantibus contigerunt, si recitare expederit, utiq[ue]; animum lectoris in admirationem verterent. Sed quia laus in ore proprio sordescit, potius expedit silentio praeterire, quam notam manis gloriae incurere: illis duntaxat exceptis, quae adeo in lucem prodierunt, quod celari non possunt."

158 See below, Chapter Three.

159 The reference to Straßburg as being in the native land of one of the inquisitors points directly to Institoris. 
little more than first-hand declarations of eye-witnessed experiences, such as those at Innsbruck - "Tamen ex his, quae oculis nostris perspeximus, \& quae uni ex Inquisitoribus innotuerunt, aliqua in medium producamus"160 - or at the village of Enningen in the diocese of Constance - "quem etiam concursum sic oculis nostriis perspeximus in villa [Enningen]"161 Anecdotal accounts of maleficia allegedly personally recounted to the inquisitors are meagre in both number and substance ${ }^{162}$ and of little value in establishing a definite

160 Malleus, II, Q.1, c.12, p. 148; [Schmidt, II, p 128].

161 Ibid., II, Q.2, p. 174; [Schmidt, II, p. 189].

162 In the most liberal estimate, the number comes to fifteen, two of which include the supposed testimony of the anonymous Inquisitor of Como [see below, Chapter Three]: I, Q.11, p. 68 [Schmidt, I, p. 158] "Est Inquisitor Cumanus, de quo supra mentio habita est [?], qui haec nobiis retulit [...]"; I, Q.15, p. 82 [Schmidt, I, p. 190] "Exemplum: ubi inter nos inquisitores unius reperit quoddam oppidum mortalitate hominum quasi destitutum [...]"; II, Q.1, c.2, p. 106, 108 [Schmidt, II, pp. 29-30, 36] - "Hunc modum nos inquisitores (experientia teste) percepimus in oppido Brisaco Basiliensis diocesis, plenam informationem capiendo ab una iuuencula malefica, sed conversa cuius et matertera in dioecesi Argentinensi incinerata fuerat [...]", "Experientia nos saepe docuit, cum omnes quas incinerari fecimus ex earum confessionibus patuit, ipsas fuisse involuntaria circa maleficia inferenda."; II, Q.1, c.3, P. 112 [Schmidt, ii, P. 44] - "Et licet duo simus hunc tractatum scribentes unus tamen exnostris saepissime tales vidit et reperit."; II, Q.1, c.7, p. 127 [Schmidt, II, p. 79] "Simile veneramdus [sic] quidam pater: honestae vitae, et scientia praeclarus in ordine, e conventu spirensi referre solebat."; II, $Q .1$, c.10, p. 141 [Schmidt, II, p. 110] - "Tempore siquidem Pij [Pius] Papae secundi, ante iniunctum inquisitionis officium, unice duobus Inquisitoribus talis accidit casus."; II, 0.1, c.12, p. 148 [Schmidt, II, p. 128] - "Tamen ex his, quae oculis nostris perspeximus, et quae uni ex Inquisitoribus innotuerunt, aliqua in medium producamus."; II, Q.1, c.13, p. 151 [Schmidt, II, p. 135] - "In diocesi namque Argentinensi et oppido Zabernio mulier quaedam honesta, ac beatissimae virgini Mariae plurimum deuota, hunc casum referre sibi accidisse, singulis eius hospitium quod publice tenet, nigram habens Aquilam pro intersegno, frequentantibus commemorat."; II, q.2, p. 174 [Schmidt, II, p. 189, 190] - "Et quidam Hengst nomine repertas, qui maiorem concursum et quotidianum a maleficiatis pauperculis habere cernitur: quem etiam concursum sic occulis nostris perspeximus in villa quadam Eningen: quod sine dubio ad quaecunque loca Beatissimae virginis, sive Aquisgrani sive ad Eremitas tantus pauperum concursus non existit sicut 
authorial presence. A closer analysis of these anecdotal accounts reveals that they could easily appertain to either of the two reputed authors. The testimony of the nun Christina from the duchy of Brabant in II, Q.1, c.1, pp. 178-9 [Schmidt, II, pp. 200-1] - "quae mihi hoc retulit" - would seem to involve Sprenger, although not necessarily so; the lengthy account of the young demoniac journeying to Rome from Dachov in Bohemia provided in II, Q.1, c.10, p. 141 [Schmidt, II, p. 110] strongly indicates Kramer - "A casu autem dum ego unus ex Inquisitoribus, hospitium refectionis gratia intrassem, contigit, ut tanquam commensalis idem sacerdos cum patre ad tabulam pariter mecum confederet." The most direct means of gauging the respective contributions of the two authors, a critical cross-comparison between the written manuscript circulated in Salzburg in 1485-6 and the first edition of the printed text in 14867 , appears to be denied to us. Instead, we have to proceed by a critical reading of the evidence internal to the printed text of the Malleus, supplemented by whatever extrinsic material is available.

Traditional scholarly opinion has customarily imputed the Malleus to Jacob Sprenger, based upon the consideration of his more well-established academic

ad eundem superstitiosum hominem"; "In civitate Spirensi mercator quidam forensis hunc casum sibi accidisse proposuit."; II, Q.2, C.1, p. 178 [Schmidt, II, p. 200] - "Christianam in valle Ducissae Brabantiae, monialem deviotam, quae mihi hoc retulit [...]"; III, $Q$. 15, pp. 248-9 [Schmidt, III, pp. 96-7] - "Unde et Cumanus Inquisitor nobis insiuavit, quod anno elapso, qui fuit 1485. unam et quadraginta maleficas incinerari mandasset, omnibus per totum corpus abrasis."; III, Q.16, p. 251 [Schmidt, III, p. 103] - "Et novissime in Dioceso Argentinensi propre oppidum Schlettstatt et castro Konigsheym malefica detenta $[\ldots] "$. 
position, coupled with a perhaps cursory reading of the ambiguously worded "Apologia auctoris". 163 The catalogues of both the British Library and the University Library of Cambridge, for instance, list their respective copies of the Malleus under Sprenger's name. Actual contemporaries of the two authors, however, as well as those who lived shortly afterwards and who may therefore be presumed to be acquainted with whatever evidence could be derived from the oral and/or unofficial traditions concerning the text, tended to regard the Malleus predominantly as the work of Institoris. To take just two such examples, Silvester Prierias (Sylvestro Mazzolini da Prierio) refers to the Malleus on at least eighteen separate occasions ${ }^{164}$ in his anti-malefic treatise De strigimagorum demonumque mirandis libri tres, first published on 24 November 1520 , placing primary emphasis upon the part played by Kramer in the production of the text and relegating Sprenger to a subsidiary role. ${ }^{165}$ Secondly, in his Monachus Pirnensis of 1530 , when the Dominican chronicler Johannes Tilanius declares about Institoris that he had "ein buch von allerlei

\footnotetext{
163 See below, Appendix A.

164 Prierias, De strigimagorum demonumque mirandis libri tres $(1575)$, I, c.1, p. 2i I, c.2, p. 4; II, c.1, p. 131; II, c.2, p. $141 ;$
p. $166,168-9,171,172 ;$ II, c.7, p. 176, 177, 180, 181; III, c. 1 , p. 214 .

165 E.g. "Vir magnus Henricus Institoris ac socius, quorum etiam opus, quod Maleficarum malleus inscribitur, universitate Coloniense probatur [...]" Prierias, De striqimaqorum demonumque librit tres, I, c.1., p. 2. No reference is ever given to Sprenger other than the purely impersonal "socius" which clearly indicates a subordinate position.
} 
zoebrei gemacht" ${ }^{166}$, he completely omits any reference to Sprenger.

The relevant information that can be gleaned from the contents of the

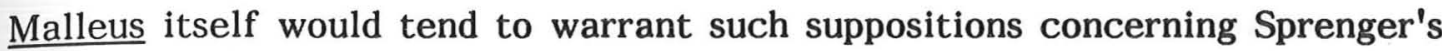
marginal role. Virtually all of the recorded incidents of maleficium that can be traced to specific locales occur in Upper Germany. From the few surviving remnants of external evidence that we possess ${ }^{167}$ it is furthermore obvious that several of the most extended and vitally important passages of the Malleus - the account of the interrogation, confession, and execution of Anna of Mindelheim and Agnes Baderin of Ravensburg in II, Q.1, c.15, pp. 161-2 [Schmidt, II, pp. 157-60], the discussion of malefic happenings at Innsbruck in II, Q.1, c.12, pp. 148-51 [Schmidt, II, pp. 128-34], and the lengthy reports of Swabian ritualistic protective magic practices in c. 7 and c.8 of II, Q.2, pp. 20310 [Schmidt, II, pp. 259-73] $^{168}$ - would more likely have been the direct result of the work of Heinrich Institoris himself, whom we know to have been acting alone in those regions at the relevant times, that is, from at least October 1485 to February 1486 . In the whole of the Malleus, there are only two references to diabolic occurrences in the northern German lands - the p. 406 .

166 Tilanius, Monachus Pirnensis, p. 1514. Cf. Hansen, Quellen,
167 See below, Chapter Three.
168 See below, Chapter Six. 
aforementioned case of Christina, the nun of Brabant ${ }^{169}$, as well as a single reference to an instance of demonically incited masturbation in Coblenz. ${ }^{170}$ Much more surprising is the almost total absence of Cologne from the text; the city is mentioned only once, in II, Q.1, c.2, p. 106 [Schmidt, II, p. 30], when the anonymous "witch of Breisach" claims to have nocturnally flown great distances with her satanic aunt, "etiam ab Argentina usque Coloniam". That Cologne should be so thoroughly neglected, considering its importance as a regional center of arbitration for witchcraft accusations in the Rhineland throughout the second half of the fifteenth century ${ }^{171}$, would be quite inexplicable if Sprenger was regarded as the primary or at least equal contributor to the composition of the treatise. Indeed, on the whole, the Lower Rhenish territories were, up to the end of the fifteenth century, largely free of the sort of malefic events described in such graphic detail in the $\underline{\text { Malleus }}^{172}$ - a fact which is in complete concordance with the utter lack of any overt concern with maleficium in both of Sprenger's rather meagre pre-Malleus writings. The central, overriding concern of the treatise is with the Upper Rhine region in general and with the Upper German territories in particular, the main areas of Heinrich

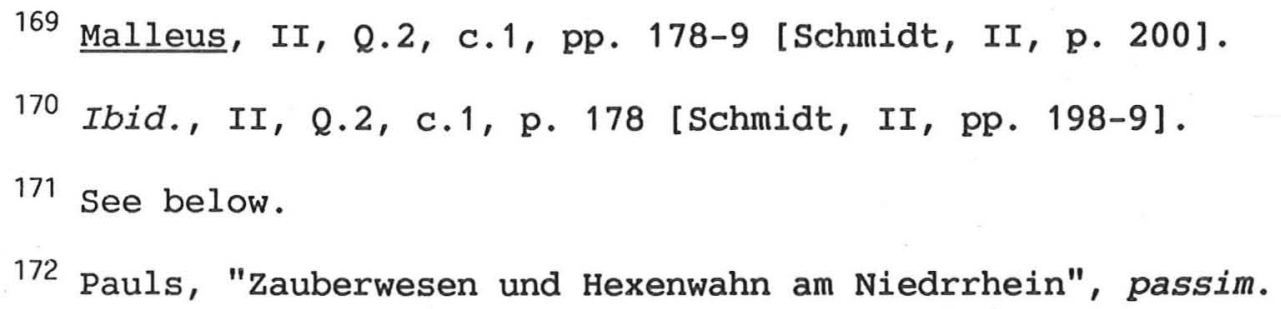


Kramer's own inquisitorial activities.

Further indirect evidence comes in the form of a letter, dated $13 \mathrm{July}$ 1496, from prior Servacius Fanckel of Cologne to Jodocus Cassel of the Abdinghof monastery at Paderborn, written in apparent response to the monk's previous enquiry as to whether Sprenger had fully collaborated in the composition of the Malleus. ${ }^{173}$ The relevant portion reads

Es quidem verum, honorande pater, quod malleus maleficarum inscribitur magistro Jacobo Sprenger pie memorie et uni alteri inquisitori sed magister Jacobus nihil apposuit aut scivit de compilatione dicti libri. 174

In the same hand, there follows an added postscript.

Prescriptus Servacius Iacobo Sprenger existente priore in Colonia sub ipso ad religionem vel conventum predicatorum ibidem susceptus est et sibi usque ad mortem familiarissimus estitit et ergo sibi constat melius, si compilaverit hunc librum. 175

173 Klose, "Die angebliche Mitarbeit des Dominikaners Jakob Sprenger am Hexenhammer nach einem alten Abdinghofer Brief", p. 197. The original copy of the letter no longer exists - instead, there is a handwritten reproduction of the epistle in the front page to the 1494 Cologne edition of the Malleus, originally held at the library at Paderborn, purchased in 1495 by the convent priest Wulfhardus. Ibid., p. 198 .

174 Ibid., p. 197.

175 Ibid., p. 198. Klose claims that the Paderborn library copy of Trithemius' Liber de scriptoribus ecclesiasticis bears the following handwritten insertion on fol. 139r., the point at which Trithemius refers to Sprenger as the author of the Malleus - "Servacius Fanckel, sacre theologie professor, conventus praedicatorum Colonie prior, de tractatu malleus maleficarum dicto, in quadam, quod vidi, epistola manu eius scripta dicit, Jacobum Sprenger, de quo supra, illum tractatum non edidisse nec de suo quicquam apposuisse, quod non discredo. Erat enim Servacius predictus eidem Jacobo, quoad vixit, familiarissimus, ut de suis secretis pre ceteris plus noverit etc." Ibid., p. 200. I have not examined the text mysej. 
Hans-Christian Klose, who has closely examined the pertinent sources, tends to believe in the veracity of the letter as Fanckel was Sprenger's immediate successor as prior and would presumably have been intimately familiar with the professor's affairs ${ }^{176}$; furthermore, there appear to be no records in the Dominican register concerning the actual composition of the Malleus, making dual authorship that much more unlikely. 177

It should be fairly easy to reconstruct the general nature of the assumed working relationship between the two reputed authors: Sprenger by and large served as a highly expedient political tool for Kramer. As the circumstances surrounding the forging of the notary instrument reveal ${ }^{178}$, Institoris was certainly not above ruthlessly exploiting his political connections as a means of realizing his own objectives. Sprenger's greater academic status as a professor at the prestigious theology faculty of Cologne, coupled with his superior political standing within the Dominican order, would have served Kramer's purposes ideally, as is attested by Sprenger's successful petitioning of Maximilian for the imperial diploma of 6 November 1486. The most likely conclusion then seems to be that Kramer in fact wrote virtually the whole of

176 Ibid., p. 199. This might be a slightly disingenous argument because it is equally plausible that Fanckel may have merely been attempting to honor his predecessor's memory, as Sprenger was clearly quite anxious to distance himself from the Malleus. Klose's position, however, is fully consistent with the other information available.

177 Ibid., p. 200.

178 see below. 
the Malleus, subtly presenting the finished text in such a way as to suggest greater personal involvement by Sprenger. ${ }^{179}$ It could well have been the case that Sprenger might have become more directly involved by reviewing the proposed work and inserting selected passages ${ }^{180}$ and references to other scholastic texts, as well as aiding in the preparations for the publication of the final version of the text, which would have included the composition of the "Apologia auctoris"181 and the submission of the treatise to the Cologne theology faculty for approval. The resultant strife between the two inquisitors after the revelation of the forging of the notary instrument, however, underscores the extent to which Sprenger was distanced from the actual machinations of the production of the text.

In any event, we must not allow our own reading and appreciation of the text to become hostage to that same set of juro-epistemological concerns regarding authorial identity which so vexed medieval commentators. For us, the Malleus does not so much reflect the reasoned opinions of an identifiable subject striving to formulate a series of unique and informative methodological innovations, but rather manifests the highly impersonal application of a series

\footnotetext{
179 Hansen, Quellen, pp. 406-7.

180 We know, for example, that the Formicarius was printed in Cologne for the first time in 1473, so that it is conceivable that Sprenger might have been the one responsible for the passages incorporated into the Malleus. Dresden-Coenders, "Witches as the Devil's Concubines", p. 59. See below, Chapter Seven.

181 See below, Appendix A.
} 
of systematic literary devices and strategies pressed into the service of the production of a set of stereotypical representations consistent with the basic canons of a pre-established discursive formation. Such structural textual concerns are enhanced rather than diluted by the self-effacing anonymity of the author(s).

II. 4. The Composition and Publication of the Malleus: Time and Place.

As none of the five editions of the Malleus printed before 1494 carry any publishing information, attempts to trace specific editions to specific sites of origin are rendered highly tenuous, difficulties being further compounded by the conventionality of the type-script employed in the production of most of the very first printings. ${ }^{182}$ There does not seem to be any official existent record pertaining to the publication of the early editions; any attempt to reconstruct the first part of the publishing history of the Malleus must therefore largely rest upon a provisional intertwining of evidence both internal and external to the text itself.

182 Hansen, "Der Malleus Maleficarum, seine Druckausgaben und die gefälschte Kölner Approbation vom Jahre 1487", p. 128. 
As the actual composition of the $\underline{\text { Malleus }}$ was instigated in response to the promulgation of the papal bull of 5 December 1484 coupled with Kramer's evidently repeated failures in securing convictions of suspected witches culminating in the fiasco in Brixen during the summer and autumn of 1485 , the most likely deduction is that the composition of the treatise was begun sometime during the mid-1480s. This conclusion is warranted by two further considerations. The first relates to the issuance of the forged notary instrument in May 1487, which was inserted into pre-existent copies of edition $\mathrm{Ib}^{183}$ for distribution outside of the principality of Cologne. This indicates that an initial printing of the text must have occurred sometime well before the "official" publication date of 19 May 1487. Furthermore, the only actual date explicitly provided by the Malleus is the year 1485 and that is only cited on three occasions - I, Q.2; II, Q.1, c.4; III, Q.16 -, each time in relation to the alleged mass burning of witches in the county of Bormio supervised by the inquisitor Cumanus. $^{184}$ In the last two instances, 1485 is referred to as the immediately previous year - "annus proxime elapsus" in I, Q.2, and "quod anno elapso qui fuit $1485 "$ in III, Q.16. Kramer must therefore have commenced his work on the original manuscript draft in Salzburg sometime near the beginning of 1486, closely following his humiliation at Innsbruck, and afterwards composing

\footnotetext{
183 See Appendix E for the publishing history of the Malleus.

184 See below, Chapter Three.
} 
the official copy of the text, possibly with some unspecifiable degree of assistance from Sprenger. The initial unof ficial printing then took place either at the end of that year or very early in 1487.185

Using the date of late 1486/early 1487 as a guideline, a closer critical examination of the first undated editions should prove fruitful. ${ }^{186}$ It seems most probable that the very first printing, texts $\mathrm{Ia}$ and $\mathrm{Ib}$, was conducted by Johann Preuss (Pryss) the Elder of Straßburg, who is known to have been active in Salzburg from 1480 onwards. The most crucial piece of evidence identifying Preuss as the first publisher lies in the fact that the type-set of these editions of the Malleus is identical to that used by Preuss for the 1480 edition of his printing of the Fasciculus temporum of Werner Rolevinck. Several additional factors support this conclusion. Although Preuss was located in Straßburg at the time of the first printing of the Malleus, it seems likely that his time in Salzburg would have made him known to Institoris. Kramer possessed direct ties to the city of Straßburg. His presumed home town of Schlettstadt was in the vicinity and he was himself Ordinis Praedicator of the diocese. Most importantly, the papal bull explicitly declared both Kramer and Sprenger to be

185 Hansen, Quellen, pp. 363-4. One malefic occurrence in Speyer related to Kramer is cited as occurring "anno eodem quo hic liber est inchoatus" (Malleus, II, Q.1, p. 96 [Schmidt, II, p. 7]); this, however, does not provide us with conclusive evidence since no source external to the Malleus specifies the year in which the testimony was given. 
under the protection of the Bishop of Straßburg, Albrecht of Bavaria. ${ }^{187}$ Thus it would have been politically most expedient for Kramer to have his text printed in the diocese in which he enjoyed official status as well as full episcopal endorsement. Preuss would have been an obvious and a useful choice as printer, especially in regards to the delicate affair of the insertion of the bogus letter of approbation. 188

It seems impossible to indicate the time and place of the publication of the other undated editions II to $\mathrm{V}$ with any great degree of exactitude. It is evident that edition II, available from Cologne booksellers in 1491, must have been printed sometime before that date. On the basis of the exterior indications available to us, it appears most likely that edition III was chronologically closer to edition II, that is sometime before 1491 , while editions IV and V, the latter almost certainly emanating from Paris, would have been published at some date nearer to $1500 .{ }^{189}$ With regards to the place of origins; it is likely that none of the undated editions emanated from Cologne. All the first printings, including the Nürnberg edition of 1496 , reduplicate the original spelling errors contained in the first printing of the notary instrument.

\footnotetext{
187 See below.

188 Hansen, "Der Malleus Maleficarum, seine Druckausgaben und die gefälschte Kölner Approbation vom Jahre 1487", pp. 124-5.

189 The catalogue of the British Library tentatively lists edition $\mathrm{V}$ by Jean Petit of Paris as being printed around 1510 .
} 
These mistakes consist largely of misspellings of the surnames of the various theology professors who signed the letter(s) of approbation, as well as the names of various town and locales around Cologne, such as "Ensskirchen"(Ib) for "Eusskirchen". Edition VII, dated Cologne 24 November 1494, however, provides the correct spellings in all instances, indicating that the printers of the other editions could not have been familiar with either the Cologne area or the university's theology faculty. 190 Considerations like these invalidate numerous authors' references to a pre-1494 Cologne edition of the Malleus ${ }^{191}$ - the Bibliotheca Magica of Graesse, published in Leipzig in 1843, cites at least two such edition乡 dated "Coloniae anno 1487" and "Coloniae anno 1489". 192 Although both editions are always cited as having been published in quarto, it is in fact edition III, the undated quarto printing that is actually referred to. It is probable that earlier bibliographers of the Malleus erroneously inferred from the notary instrument that 19 May 1487 signified the publishing date of the text itself. Confusions concerning the alleged 1489 Cologne edition appear to result from the text of edition III, which was bound and printed together as an omnibus edition with Ulrich Molitor's De Pythonicis mulieribus, dated 10 January

\footnotetext{
190 Hansen, "Der Malleus Maleficarum, seine Druckausgaben und die gefälschte Kölner Approbation vom Jahre 1487", p. 128-9. p. 281 .

191 Cf. Karl Georg Waechter, Beiträge zur Deutschen Geschichte,

192 Cf. Summers, The Malleus Maleficarum, p. xli.
} 
1489. ${ }^{193}$ Any bibliographer working in a hurry could easily have drawn the obvious, but false, conclusion. ${ }^{194}$

\section{5. The Surnmis Desiderantes Affectibus.}

The grossly exaggerated importance normally ascribed to the "Witch Bull" promulgated by Pope Innocent VIII (Giovanni Battista Cibo) on 5 December 1484 makes it perhaps the most overrated document in the entire history of the European witchcraft persecutions. ${ }^{195}$ The document is a Fakultät, i.e. a formal papal authorization of a specific office to be fulfilled by a specific person for the indefinite future. Although it is exceptional in being issued "ad perpetuam rei memoriam", the Summis fully belongs in that long series of Fakultäten issued throughout the fourteenth and fifteenth centuries which empowered numerous inquisitors and instructed them in their duties. 196

193 See below, Chapter Three.

194 Hansen, "Der Malleus Maleficarum, seine Druckausgaben und die gefälschte Kölner Approbation vom Jahre 1487", p. 129.

195 Hansen, Zauberwahn, pp. 467-75; Soldan-Heppe, Die Geschichte der Hexenprozesse, I, pp. 245-70.

196 For a collection of such documents, see Hansen, Quellen, pp. 1-37. The judicial and diplomatic status of these Fakultäten are discussed at length by Ernst Pitz in his "Diplomatische Studien zu den 
While many historians have traditionally viewed the $\underline{\text { Summis }}$ as the most crucial document signalling the willingness of higher ecclesiastical authorities to engage in the extensive prosecution of witches ${ }^{197}$, closer examination reveals that it is, in fact, a wholly conventional account of papal views regarding diabolic magic. The entire notion of witchcraft is hardly touched upon and the very word maleficium is never actually used. ${ }^{198}$ Even the most cursory reading of the previous major papal decrees concerning the threat of satanic magical practices, most notably the pronouncements of John XXII ${ }^{199}$ and Eugen $\mathrm{IV}^{200}$, shows the total absence of any substantial structural or thematic differences between these earlier texts and the Summis. As regards its actual theological content, the Bull appears surprisingly meagre. It is primarily a political document, issued by Innocent in response to Kramer's and (presumably) Sprenger's petitioning of the papal curia for a declaration of support in the face

Päpstlichen Erlassen über das Zauber- und Hexenwesen", passim.

197 Robbins, Encyclopedia of Witchcraft and Demonology, pp. 263-6.

198 "Witchcraft" is referred to only as haeretica pravitas. Innocent does, however, make explicit mention of maleficorum in his epistle to Archduke Sigmund of 18 June 1485. Hansen, Quellen, p. 28.

19927 February 1318; 22 August 1320; 1326-7; 4 November 1330; 12 April 1331. Hansen, Quellen, pp. 2-8. John is most concerned with homeopathic magic and ritualistic court sorcery. Riezler, Die Geschichte der Hexenprozesse in Bayern, p. 84.

20024 February 1434; 1437; 23 March 1440; 17 July 1445. Reprinted in Hansen, Quellen, pp. 17-18. Eugen cites as examples of crimen magiae adoration of the devil, the demonic pact, the demonic infliction of illness, the raising of tempests, and diabolic divination. Cf. Riezler, Die Geschichte der Hexenprozesse in Bayern, p. 85 . 
of deeply entrenched regional ecclesiastical and lay opposition to their inquisitorial practices. $^{201}$ The Summis is in fact an outstanding example of a Reskript, i.e. a specific form of papal authorization issued in response to a petition previously sent to the curia which seeks to elicit papal instruction on a politically and/or ecclesiastically sensitive issue. ${ }^{202}$

A careful examination of the Summis reveals its essentially political nature. After lamenting the reported spread, provided by uncited sources, of heretical depravity ("haeretica pravitas") throughout the dioceses of Mainz, Cologne, Trier, Salzburg, and Bremen - that is, all the archbishoprics of Germany west of the Elbe - the bull proceeds to provide a short account of the satanic machinations of the alleged heretics. Although Innocent cites carnal intercourse with devil ("cum daemonibus incubis et succubis abuti"), his listing of customarily popular concerns with witchcraft - namely, the supernatural infliction of sexual impotency and sterility, deformed births, agrarian blight replicates in succinct fashion a microscopic model of the way in which lay concerns with magic were actively assimilated into and re-interpreted within the context of "high" scholastic and judicial concern. There is no reference to nocturnal flight and the only suggestion of either the satanic pact or the witch Sabbat is a very indirect one.

201 Peters, The Witch, the Maqician and the Law, pp. 172-3.

202 Pitz, "Diplomatische Studien zu den Päpstlichen Erlassen über das Zauber- und Hexenwesen", p. 56. 
Fidem praeterea ipsam, quam in sacri susceptione baptismi susceperunt, ore sacrilego abnegare, aliaque quam plurima nefanda, excessus et crimina, instigante humani generis inimico, committere et perpetrare non verentur, in animarum suarum periculum, divinae maiestatis of fensum ac perniciosum exemplam ac scandalum plurimorum. ${ }^{203}$

After this rather tenuous identification of haeretica pravitas with diabolism ${ }^{204}$ Innocent discusses in extended detail the judicial plight of the apparently hapless inquisitors Heinrich Institoris and Jacob Sprenger. More than half of the remaining text it devoted to the "vexing problem of local opposition to [the] papal inquisitors". ${ }^{205}$ After specifying Institoris as the fully empowered inquisitor for heretical depravity in upper Germany ("Alamaniae superioris") for all those territories and dioceses previously cited and Sprenger for certain parts of the Rhineland ("certas partes lineae Rheni"), the Pope then goes on to make a highly revealing comment concerning the insolent insubordination of certain local clerics within these regions. Although both of the members of the order of preachers had received full recognition through previous papal letters ("literas apostolicas deputati fuerint")

tamen nonulli clerici et laici illorum partium, quaerentes plura sapere quam operteat, pro eo quod in literas deputationis huiusmodi provinciae,

203 Reprinted in Schmidt (ed.), Jakob Sprenger, Heinrich Institoris: Der Hexenhammer (Malleus Maleficarum), pp. XXXII-XXXVI.

204 It is important to note that the bull neither presents any "sophisticated" account of witchcraft nor even appears to consider witchcraft as a separate category of supernatural transgression clearly identifiable from the more traditional forms of heretical devilworship.

205 Peters, The Witch, the Magician, and the Law, p. 172. 
civitates, dioceses, terrae et alia loca praedicta illarumque personae ac excessus huiusmodi nominatum et specifice expressa non fuerunt, illa sub eisdem partibus minime contineri et propterea praefatis inquisitoribus in provinciis, civitatibus, diocesibus, terris et locis praedictis huismodi inquisitionis officium exequi non licere et ad personarum earundem super excessibus et criminibus antedictis punitionem, incarcerationem et correctionem admitti non debere, pertinaciter asserere non erubescunt. 206

Innocent declares it his duty to remove all hindrances blocking the actions of

the inquisitors and states:

eisdem inquisitoribus in illis officium inquisitionis huiusmodi; exequi licere et ad personarum earundem super excessibus et criminibus praedictis correctionem, incarcerationem et punitionem admitti debere, perinde in omnibus et per omnia acsi in,literis predictis provinciae, civitates, diocese, terrae et loca ac personae et excessus huiusmodi nominatim et specifice expressa forent, auctoritate apostolica temore praesentium statuimus.

Furthermore, Kramer and Sprenger are both fully empowered

praedictis contra quascumque personas, cuiuscumque conditionis et praeeminentiae fuerint, huiusmodi inquisitionis of ficium exequi ipsaque personas, quas in praemissis culpabiles repererint, iuxta earum demerita corrigere, incarcere, punire et mulitare, necnon in singulis proviciarum huiusmodi parochialibus ecclesiis verbam dei fideli populo quotiens expedierit ac eis visum fuerit, proponere et praedicare, omniaque alia et singula in praemissis et circa ea necessaria et opportuna facere et similiter exequi libere et licite valeant, plenam ac liberam eadem auctoritate de novo concedimus facultatem.

The Summis thus clearly demonstrates that the opposition to the inquisitors was centered on those perceived restrictions inherent within the previously issued

206 The Innsbruck trials of $1485-6$ are a striking example of the way in which local clerics 'seeking to know more than concerns them' could totally undermine Kramer's judicial effectiveness. See below, Chapter Three. 
documents of authorization; hence, the Summis' declaration that the inquisitors were to have full power over all people at all times and places almost certainly reflects the papal responsiveness to Institoris' own pleading. ${ }^{207}$ After commending the two inquisitors to the protective care of the bishop of Straßburg ${ }^{208}$ the bull concludes with a dire threat, Innocent instructing Bishop Albrecht

non permittat eos per quoscumque super hoc contra praedicatorum et praesentium literarum tenorem quavis auctoritate molestari seu alias quomodolibet impediri, molestatores et impedientes et contradictores quoslibet et rebelles, cuiuscumque dignitatis, status, gradus, praeeminentie, nobilitatis et excellentiae aut conditionis fuerint et quocumque exemtionis privilegio sunt muniti, per excommunicationis, suspensionis et interdicti ac alias etiam formidabiliores, de quibus sibi videbitur, sententias, censuras et poenas, omni appellatione postposita, compescenda, et etiam legitimmis super his per eam servandis processibus, sententias ipsas, quotiens opus fuerit, aggravare et reaggravare auctoritate nostra procuret, invocato ad hoc, si opus fuerit, auxilio brachii saecularis.

What is most striking about the text is not its minimal concern with the nature and reality of witchcraft, but rather the tremendous judicial powers that it grants the two inquisitors against all possible opponents, including members of the aristocracy, - all of which is indicative of the tremendous amount of

207 Pitz, "Diplomatische Studien zu dne Päpstlichen Erlassen über das Zauber- und Hexenwesen", p. 55.

208 Albrecht of Bavaria. The designation of Albrecht as custodian would appear to have less to do with any involvement of the bishop in witchcraft trials or the rate of alleged malefic activity within Straßburg but rather with the fact that Kramer himself was the ordinis praedicator of the diocese - a consideration which indirectly attests to Kramer's own personal role in obtaining the promulgation of the Summis. 
opposition the author(s) must have encountered during his/their career(s) as witch hunters. ${ }^{209}$ As Sigmund Riezler has pointed out, the Summis does, at least in its formal structure, in some way imply a degree of papal commitment to the prosecution of witches far greater than that evidenced in any previous curial pronouncement. ${ }^{210}$ But even this display of apostolic support ultimately proved ineffectual in assisting the workings of the machinery of prosecution as the Bishop of Brixen's adroit manipulation of common law in circumventing papal authority clearly demonstrates. ${ }^{211}$ Far from being viewed within a quasi-teleological framework, the end product of a steadily intensifying papal concern with malefic subversion stretched out over the course of several centuries, the $\underline{\text { Summis }}$ can be most profitably regarded as a document of bureaucratic expediency, structured in such a way as to undermine the ground of the juro-political opposition encountered by Institoris while active in the field. The historical significance that the Summis in fact possesses is almost entirely derived from the political expediency of its incorporation by Kramer into the original text of the Malleus, which ensured that the decree was reprinted with every subsequent re-issuing of the text. This highly self-serving manoeuvre itself ultimately proved to be successful in securing Kramer's

\footnotetext{
209 The forms which this opposition may have taken will be discussed in more detail in Chapter Three.

210 Riezler, Die Geschichte der Hexenprozesse in Bayern, p. 86.

211 See below, Chapter Three.
} 
opposition the author(s) must have encountered during his/their career(s) as witch hunters. ${ }^{209}$ As Sigmund Riezler has pointed out, the Summis does, at least in its formal structure, in some way imply a degree of papal commitment to the prosecution of witches far greater than that evidenced in any previous curial pronouncement. ${ }^{210}$ But even this display of apostolic support ultimately proved ineffectual in assisting the workings of the machinery of prosecution as the Bishop of Brixen's adroit manipulation of common law in circumventing papal authority clearly demonstrates. ${ }^{211}$ Far from being viewed within a quasi-teleological framework, the end product of a steadily intensifying papal concern with malefic subversion stretched out over the course of several centuries, the $\underline{\text { Summis }}$ can be most profitably regarded as a document of bureaucratic expediency, structured in such a way as to undermine the ground of the juro-political opposition encountered by Institoris while active in the

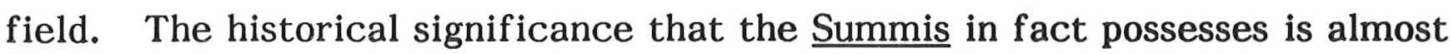
entirely derived from the political expediency of its incorporation by Kramer into the original text of the Malleus, which ensured that the decree was reprinted with every subsequent re-issuing of the text. This highly self-serving manoeuvre itself ultimately proved to be successful in securing Kramer's

209 The forms which this opposition may have taken will be discussed in more detail in Chapter Three.

210 Riezler, Die Geschichte der Hexenprozesse in Bayern, p. 86.

211 See below, Chapter Three. 
objective of obtaining greater papal approval for his inquisitorial activities, an ambition revealed through Kramer's entitling the document "Bulla apostolica adversus haeresim maleficarum" 212 : by the end of the sixteenth century, the Summis was commonly cited as the most authoritative papal pronouncement guaranteeing the ecclesiastical and judicial propriety of witchcraft trials.

\section{6. The Notary Instrument of 19 May 1487} and the University of Cologne.

The notary instrument of 19 May 1487, which accompanies the two letters of approbation allegedly issued that same year by the theology faculty of Cologne University, immediately arouses suspicions about its authenticity. The document, entitled "Sequitur in sequentem tractatum approbatio et subscriptio doctorum alme universitatis Coloniensis iuxta formam publici instrument", is sub-divided into several component parts. In the first section, the notary responsible for drawing up the certificate, Arnold Kolich, declares that, on 19 May 1487 at approximately 5:00 p.m., he interviewed Heinrich Institoris in the presence of those witnesses "infrascriptorum ad hoc specialiter vocatorum et

212 Riezler, Die Geschichte der Hexenprozesse in Bayern, p. 87. 
rogatorum presentia". Institoris, claiming to act on behalf of his colleague Jacob Sprenger - "pro se et dicto collega suo proposuit atque dixit" -, presented Kolich with a signed and certified copy of the Summis desiderantes authorizing Kramer and Sprenger to perform their duties as inquisitors of heretical depravity for the dioceses of Mainz, Cologne, Trèves, Salzburg, and Bremen. Kolich declares the Bull to be legitimate.

The next part commences with the bald assertion that the general scepticism of the clergy regarding the reality of maleficium completely undermines the efforts of the inquisitors - a problem to be remedied by the publication of an inquisitorial manual.

Et quia nonnulli animorum rectores et verbi Dei predicatores publice in eorum sermonibus ad populam asserere et affirmare non verebantur, maleficus non esse, aut quod nihil in nocumentum creaturarum quacunque operacione efficere possent, ex quibus incautis serminbus nonunquam seculari brachio ad puniendum huiusmodi maleficas amputabatur facultas, et hoc in maximum augmentum maleficarum et confortationem illius haeresis, ideo prefati inquisitores, totis eorum viribus cunctis periculis et insultibus obviare volentes, tractatum quendam non tantum studiose quantum et laboriose collegerunt, in quo non tantum huiusmodi predicatorum ignorantiam pro catholice fidei conservatione repellere nisi sunt, quantum etiam in exterminium maleficarum debitos modos sententiandi et easdem puniendi, iuxta dicte bulle tenorem et sacrorum canonum instituta laborarunt. 213

In order to strengthen their cause in the crusade against witches the inquisitors sought the full approval of the University of Cologne.

213 The letter of approbation is reprinted in the Malleus (1669), pp. 302-5. 
At quoniam consonum racioni est, ut ea que pro communi utilitate fiunt, etiam communi approbacione doctorum roborentur, ideo ne prefati rectores discoli et predicatores sacrarum litteram ignari estimarent, predictum tractatum, sic ut premittitur collectum, minus bene doctorum determinationibus et sententiis fulcitum, eundem alme universitati Coliensi, seu nonnullis ibidem sacre pagine professoribus ad discutiendum et coolacionandum obtulerunt, ut si qua reprehensibilia at a catholica veritate dissona reperirentur eorum iudicio sic refutarentur, quod tamen consona Catholice veritati approbarentur.

It follows a document ("Quod et subscriptis modis factum fuit") signed by Lambertus de Monte ${ }^{214}$, professor of sacred theology and dean of the theology faculty of Cologne ("manua sua propria se subscripsit prout sequitur") which solemnly declares that

itsum tractatum tripartitum per me lustratum et diligenter collationatum quoad eius partes duas primas nihil continere, saltim meo humili iudicio, quod sit contrarium aut sententiis non errantium philosophorum aut contra veritatem sancte ecclesia approbatorum aut admissorum.

Mirroring the structure of the Malleus itself, which contains a theological discussion of the nature and reality of maleficium in Parts One and Two and a series of recommendations for the judicial persecution of witches in Part Three, de Monte divides his own comments into two parts. In the first section, he declares that, in his own judgement, the first two parts of the treatise contain

214 The most influential Thomist and neo-Aristotelian theologian at Cologne during this time. Matriculated at Cologne in 1450; doctor of theology in 1475; dean of the theology faculty on 1475, 1486, and 1496. De Monte's extreme thomistic outlook is best expressed through the famous anecdote of his wish to petition the curia for the canonization of Aristotle. Hansen, "Der Malleus Maleficarum, seine Druckausgaben und die gefälschte Kölner Approbation vom Jahre 1487", p. 147. See also Hartzheim, Bibliotheca Coloniensis, p. 214; Keussen, Matrikel der Kölner Universität, I, 247, 68; Krafft, Briefe und Dokumente aus der Zeit der Reformation, p. 180 ; Prantl, Geschichte der Logik im Abendlande, IV, p. 224. 
nothing that in any way contradicts the teachings of the infallible classical philosophers or the divinely inspired truths of the Church. ${ }^{215}$ The second part states that nothing in the Third Part of the Malleus violates the basic principles of canon law. ${ }^{216}$ Because of the extremely graphic and detailed descriptions of the reported instances of witchcraft, however, he holds that caution should be exercised in the distribution of the treatise, the text to be restricted only to those church rectors and the most zealous members of the Faith in the fight against maleficia.

Iterum propter experimenta in hoc tractatu narrata, que utique propter famam tantorum virorum precipuorum etiam inquisitorum creduntur esse vera, consulendum tamen videtur, quod iste tractatus doctis et viris zelosis, qui ex eo sana, varia et matura consilia in exterminium maleficarum conferre possunt, communicetur, simul et ecclesiarum rectoribus timoratis et conscientiosis duntaxat, ad quorum doctrinam subditorum corda in odium tam pestifere heresis incitari poterunt, ad cautelam bonorum pariter et malorum inexusabilitatem atque puncionem, ut sic misericordia in bonis et iustitia in malis luce clarius pateat.

To this statement are appended the signatures of three further members of the theology faculty, Jacob de Stralen ${ }^{217}$, Andreas de Ochsenfurt ${ }^{218}$, and

215 "quoad eius partes duas primas nichil continere, saltim meo humili iudicio, quod sit contrarium aut sententis non errantium philosophorum aut contra veritatem sancte catholice et apostolice fidei."

216 "Tercia etiam pars utique sustinenda et approbanda quoad illorum hereticorum puniciones, de quibus tractat, in quantum sacris canonibus non repugnat."

217 Jacob Stralen de Noetlink. Matriculated at Cologne in 1440; doctor of theology in 1459; dean of the theology faculty in 1459, 1471, 1485, and 1494 ; rector of the university in 1474 and 1487 ; vicechancellor of the university in 1479, 1482, and 1499. Hansen, "Der Malleus Maleficarum, seine Druckausgaben und die gefälschte kölner 
Thomas de Scotia. 219

The instrument then provides a second series of declarations totalling four in number. ${ }^{220}$ It says firstly, that the professors of sacred theology who have subscribed their names openly recognize the papal authority of the two inquisitors and that they encourage them to fulfill to the utmost the duties of their office; secondly, that the belief in the divine permission as a necessary precondition of maleficium contradicts neither Scripture nor the Church Fathers; thirdly, that it is a grave error publicly to preach against the reality of maleficium, and that all who do so undermine the sacred work of the inquisitors $^{221}$; and fourthly, and most significantly, that all Catholic princes, as well as the Faithful, should lend their full support and co-operation to the

Approbation vom Jahre 1487", pp. 147-8. Also, Hartzheim, Bibliotheca Coloniensis, pp. 154, 156; Keussen, Matrikel der Kölner Universität, I, 205, 11.

218 Andreas Schermer from Ochsenfurt. Matriculated at Cologne, 1468; Doctor of theology in 1486; dean of the theology faculty in 1493; rector of the university in 1504. Hansen, "Der Malleus Maleficarum, seine Druckausgaben und die gefälschte Kölner Approbation vom Jahre $1487 "$ " p. 148; Also Keussen, Matrikel der Kölner Universität, I, 300, 40.

219 Thomas Lyel de Scotia (de Parisius). One of the most important professors of theology at Cologne. Came to Cologne from Paris in 1461; dean of the theology faculty in 1491, 1498, and 1516; rector of the university in 1489, 1502, and 1509. Hansen, "Der Malleus Maleficarum, seine Druckausgaben und die gefälschte Kölner Approbation vom Jahre 1487", p. 148; Also Hartzheim, Bibliotheca Coloniensis, p. 308; Keussen, Matrikel der Kölner Universität, I, 291, 66 .

220 "Subsequenter et secunda subscriptio contra prefatos predicatores incautos sic actu fuit."

221 "Secreta tamen que quondoque ab inquisitoribus audiuntur, non sunt omnibus revelanda." 
inquisitors in the execution of their duties - "exhortandi veniunt omnes principes et quicunque catholici, ut assistere dignentur tam piis votis inquisitorum pro defensione sancte catholice fidei." This bold pronouncement is followed by a rather curious comment.

Demum vero subscripti et suprascripti doctores predicte facultatis theologie manibus propriis se subscripserunt, prout ego Arnoldus notarius infrascriptus ex relatione honesti Johannis Vorde de Mechlinia, alme universitatis Coloniensis bedelli iurati, qui michi hoc retuli audivi, et (ut ex manibus etiam supra et infrascriptis apparuit) vidi, in hunc qui sequitur modum -

- specifically, the signatures of Lambertus de Monte, Jacobus de Stralen, Udalricus Kridwiss of Esslingen ${ }^{222}$, Conradus Campea 223 , Cornelius de Breda $^{224}$, Thomas de Scotia, Theoderich de Bummel ${ }^{225}$, and Andreas de

222 Uldrich Kridwis from Esslingen. Matriculated at Cologne in 1453; doctor of theology in 1476; dean of the theology faculty in 1476, 1487, 1495, and 1499; rector of the university in 1482 and 1498; vicechancellor of the university 1498. Hansen. "Der Malleus Maleficarum, seine Druckausgaben und die gefälschte Kölner Approbation vom Jahre $1487^{\prime \prime}$ p. 148; Also Keussen, Matrikel der Kölner Universität, I, 260, 5 .

223 Konrad Vorn from Kampen. Matriculated at Cologne in 1464; doctor of theology in 1477; dean of the theology faculty in 1477 and 1489 ; rector of the university in 1473 and 1485. Hansen, "Der Malleus Maleficarum, seine Druckausgaben und die gefälschte kölner Approbation vom Jahre 1487", p. 148; Also Keussen, Matrikel der Kölner Universität, I, 270,14 .

224 Cornelius Pays de Breda. Matriculated at Cologne in 1443; doctor of theology in 1478; dean of the theology faculty in 1478, 1490, and 1497; rector of the university in 1472 and 1493; vice-chancellor of the university in 1491. Hansen, "Der Malleus Maleficarum, seine Druckausgaben und die gefälschte Kölner Approbation vom Jahre 1487", p. 149; Also Keussen, Matrikel der Kölner Universität, I, 217, 28.

225 Theodericus de Balveren (alias de Bummel). Matriculated at Cologne in 1442; doctor of theology in 1490. Hansen, "Der Malleus Maleficarum, seine Druckausgaben und die gefälschte Kölner Approbation vom Jahre 1487", p. 419; Also Keussen, Matrikel der Kölner Universität, I, 214, 19 . 
Ochsenfurt.

In the following paragraph, Kolich states that Institoris then presented him with the diploma of Emperor Maximilian, dated Brussels 6 November 1486, bestowing official recognition upon the two inquisitors and stipulating that his subjects should extend every form of assistance to them so as to facilitate the discharge of their office. The notary then specifies that "frater Henricus inquisitor", on behalf of his absent colleague - "pro se et collega" - had sought Arnold officially to draw up and relegate the aforementioned letters and documents in the form of a public instrument, this having been accomplished within the household of Lambertus de Monte, situated in the vicinity of the Church of Saint Andrew, and witnessed by de Monte, the beadle Johannis Vorde, Nicholas Cuper of Venroid, notary of the curia of Cologne, and Christian Wintzen of Eusskrichen, a cleric in the diocese of Cologne. Arnold finally attests to the legitimacy of the instrument, having drawn it up "sic fieri vidi et, ut prefertur, [et quod] ex relacione bedelli audivi".

One of the most striking, and disturbing, features of the notary instrument is its claim to absolute dogmatic theological authority. Surviving examples of authentic letters of approbation from Cologne, which have been analyzed at length by Joseph Hansen, bring out the instrument's deviations from the norm quite clearly. It was customary for Gutachten to be presented as reflecting the considered opinions of select members of the theology faculty; one Gutachten, 
dated 1470, for example, contains the signatures of eight theology professors, all of whom clearly refer to themselves as consenting individuals acting by themselves, not on behalf of the entire faculty - "magistorum quorundam Coloniensium privata sententia". However, as its very title indicates, the instrument of 19 May 1487, purports to represent the collective opinion of the university, implying that the authors had submitted the text to the body of the faculty in its entirety, which was clearly not the case. ${ }^{226}$

Another acute problem is the stark contrast in both tone and content between the first and second signed letters. The first letter, with its modest and sober evaluation of the nature and worth of the Malleus, urging its restricted usage by a select membership, represents the sort of pronouncement to be expected from an orthodox theologian of the fifteenth century. 227 Furthermore, despite its moderate tone, it bears the signatures of only four theologians, which is indicative of a lack of enthusiastic support. ${ }^{228}$ The second letter therefore appears highly suspect, as it so strikingly conflicts with the tone and substance of the first one; it unconditionally demands the widespread dissemination of the text as well as the unquestioning compliance

226 Hansen, "Der Malleus Maleficarum, seine Druckausgaben und die gefälschte Kölner Approbation vom Jahre 1487", pp. 135-7.

227 Ibid., p.152.

228 Ibid., p. 152 . 
of all the Faithful with the inquisitorial efforts of Kramer and Sprenger. ${ }^{229}$ The second signed letter of approbation incorporated into the instrument, with the four additional signatures lending considerable weight to its authoritative claims, then represents in every way an instrument that is ideally suited to the wishes and practical needs of a zealous inquisitor. ${ }^{230}$

Another revealing feature of the second letter is the irregular way in which Kolich actually cites the document. It appears obvious that the instrument is constructed in such a way as to convey the impression that Kramer, explicitly acting alone, had brought four separate documents to be officially notarized by Kolich - the Summis desiderantes, the diploma of Maximilian, and the two signed letters from the university. In actual fact, however, the notary's treatment of the second letter would appear to violate the tenets of medieval jurisprudence, as its authenticity is established solely by the alleged verbal testimony of "honesti" Johannis Vorde, given to Kolich at some unspecified previous date. In late fifteenth-century legal practice it was wholly without precedent for a notary to vouch for the legitimacy of a document which he had not witnessed personally. ${ }^{231}$ Yet, as the instrument indicates, the responsibility for establishing the genuineness of the second

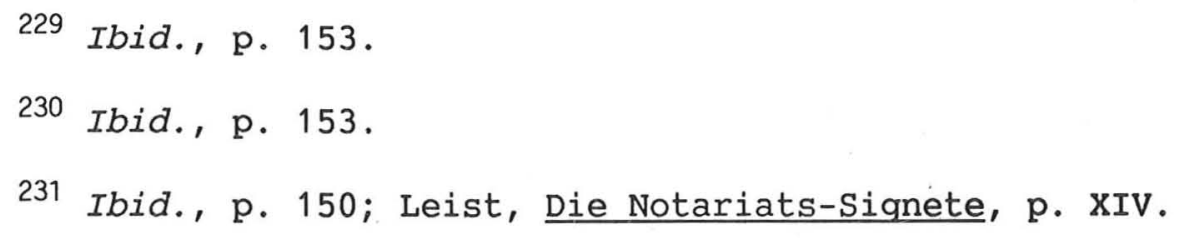


document was entirely given over to Vorde. ${ }^{232}$

Within the context of this rather Byzantine-like intrigue, the person of the beadle himself acquires interest. Johannes Vorde of Mecheln, matriculated at Cologne University as an arts student in 1452 and was elected Pedell in $1465 .^{233}$ He also served as public notary from 1479 to 1490 . By 1487 he must have been well into middle age, and, as it appears, in a fragile state of health. On 16 February 1492 Johannes requested that his post at the university be transferred to his son Heinrich, and he died on 2 February in the following year. $^{234}$ The only external reference to Vorde's role in the affair appears to be a handwritten inscription by Joseph Hartzheim, secretary of the deanery of the Cologne theology faculty in the eigthteenth century, in the copy of edition IV of the Malleus which is kept in the Stadtarchiv of Cologne "Approbationem sacrae facultatis theologicae confictam esse, docent Thomas de Scotia, qui refertur inter subscriptores, et Johannes de Vorda de Mechlinia,

232 "Die Verantwortung für die Echtheit dieses zweiten Gutachtens war vollständig dem Pedell zugeschoben; denn so sehr auch durch den Tenor des ganzen Instruments dem Leser nagelegt war zu glauben, dass Institoris die beiden Gutachten coram testibus vorgelegt habe und dass sie beide als authentisch anerkannt worden seien, ausdrücklich gesagt war es nirgends; der Notar konnte sich nach dem Wortlaut seines Instrumentes und seiner Unterfertigung stets auf eine ihm ausserhalb des Aktes gewordene Mitteilung des Pedellen zurückziehen, wenn etwa Zweifel an der Echtheit dieses zweiten Gutachtens ausgesprochen werden sollten." Hansen, "Der Malleus Maleficarum, seine Druckausgaben und die gefälschte Kölner Approbation vom J. 1487", p. 150.

233 Keussen, Die Matrikel der Kölner Universität: 1389-1559, 255, 43.

234 Hansen, "Der Malleus Maleficarum, seine Druckausgaben und die gefälschte Kölner Approbation vom Jahre 1487", p. 153. 
qui ambo fatentur in libro decanali facultatis theologicae, se nunquam huiusmodi instrumento subscripsisse." 235 Subsequent cross-referencing with the first editions of the Malleus lends credence to such suspicions concerning the letter's veracity. The very first dated edition of the Malleus, complete with full publishing information, was the printing by Antonium Koberger of Nürnberg of 17 March 1494, with the other two dated pre-1500 editions printed in Cologne on 24 November 1494 by Joannes Koelhoff ${ }^{236}$ and re-issued on 17 January 1496 by Koberger. Significantly, all these editions came after Vorde's death; no edition of the Malleus had apparently been published in Cologne during his life-time. With regards to the undated pre-1494 editions, at least two had been issued sometime before 1491, both I and II having been published outside Cologne, the first arguably by Preuss in Straßburg. ${ }^{237}$ Closer inspection of edition I, however, reveals that it had been issued in two separate forms - Ia, without the certificate, and $\mathrm{Ib}$, which includes a copy of the instrument but printed on different paper and in a different typescript, furthermore, erroneously inserted at the front of the text. Edition II contains the instrument printed in the same type as the rest of the text and placed at the end. Although

235 Reprinted in ibid., p. 155.

236 Cf. Voullième, Der Buchdruck Kölns bis zum Ende des 15. Jahrhunderts, pp. 289-90, n. 637 "Institoris, Henricus \& Sprenger, Jacobus: Malleus maleficarum. Coloniae: Johannes Koelhoff filius 24 Nov. 1494."

237 See above. 
printed elsewhere, it appears that either Ib or II were available in Cologne bookstalls by 1491 at the earliest. This rather convoluted publishing history strongly suggests that the composers of the Malleus craftily manipulated the first edition in order that only that part of it which did not include the instrument could reach Cologne, thereby preventing knowledge of the forgery - a ploy which obviously failed, given both Vorde's and Lambertus de Scotia's declarations, presumably of 1491 , that they had never either signed or witnessed the second letter of approbation. ${ }^{238}$

It should thus be possible to reconstruct the general course of events of the forgery of the second letter. Institoris, probably acting without Sprenger's knowledge, appeared before Kolich with the three legitimate documents - the Summis, the imperial diploma, and the first letter - for a notarizing ceremony witnessed by Lambertus de Monte, de Vorde, Nicholas Cuper of Venroid, and Christian Wintzen of Eusskirchen. During the proceedings, Kolich, almost certainly acting on Kramer's behalf, inserted the reference to the bogus second letter in such a manner that it was not the legitimate instrument itself which vouched for the authenticity of the second clarification but rather another external notification which had been supplied Arnold by Vorde, an old and ill man easily manipulated by the notary. ${ }^{239}$ The illegal instrument was then

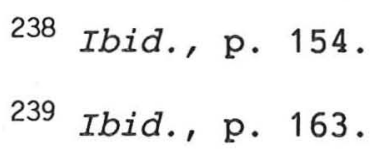


reprinted separately, presumably at Straßburg, and inserted into those copies of the first edition destined for distribution outside of Cologne. The fact that no official charges were laid following de Vorde's and Lambertus' denunciations is attested to by Koelhoff's 1494 publication of the Malleus, which produces the second letter intact. It is interesting to speculate upon the reasons for the apparent lack of legal action. It could well be that Kolich's reference to the beadle's sworn testimony did indeed prove effective. A more likely reason, however, is that the university probably felt insufficiently motivated to initiate legal proceedings as it was clearly Kramer and not Sprenger who undertook the notarization and therefore must have planned the forgery. That the whole affair proved scandalous is demonstrated by Sprenger's efforts afterwards to dissociate himself from Kramer - if not, indeed, from the Malleus itself. Furthermore, the university's decision to refuse Sprenger the traditional Seelenamt customary for distinguished professors of theology was almost certainly due to the odious after-effects of the forgery incident, particularly since the university rector at the time of Sprenger's death was none other than Ulrich Kridwiss of Esslingen, one of the four additional professors cited in the fake document. ${ }^{240}$ Furthermore, in 1510, the dean of the theology faculty, Arnold of Tongern, wrote in the deanery book for that year that "Liber, qui Malleus Maleficarum dicitur, falso facultati inscriptis. Examinandus traditur uni

240 Ibid., pp. 163-5. 
magistrorum cum relatione ad facultatem."241 Such legalistic consternation ultimately proved irrelevant as the popularity and authoritative status of the Malleus demonstrated the degree to which the notary instrument was regarded as an official pronunciation of the theology faculty of Cologne.

The most pressing question to be answered is, of course, why Institoris resorted to such a clumsy fabrication, especially since he had already received an endorsement of four theology professors including that of the dean of the faculty. The most ready answer appears in the second paragraph of the instrument, which condemns the clergy's great ignorance concerning the reality of the threat of malefice and their deeply engrained resistance against the persecution of witches. The whole passage is almost certainly a direct expression of the intense resentment Kramer must have felt towards the hostile opposition he must have had encountered throughout the greater part of his witch-hunting career, culminating in his humiliation and disgrace at Innsbruck. ${ }^{242}$ Indeed, echoing the second part of the instrument, the Malleus on several occasions denounces the sceptics, clerical or otherwise, for impeding the authors' efforts in trying witches. ${ }^{243}$ Kramer must desperately

241 rbid., p. 165.

242 See below, Chapter Three.

243 E.g. Malleus, II, Q.1, c.3, p. 111 [Schmidt, II, p. 42], where Institoris condemns as heretical the view of nocturnal flight as hallucination: "[...] et contra sacrae Scripturae intentionem, et ad Ecclesiae sanctae intolerabile damnum, ubi iam multis annis impune ex hac perstifera opinione permanserunt, seculari brachio puniendo 
have felt the need to provide the Malleus, itself the direct result of his experiences at Brixen, with the strongest possible evidence of complete academic, ecclesiastical, and judicial authority. However, as we know from the first letter of approbation, the initially given support was qualified by great caution. The underlying reservation evidenced by the first letter was, however, less the result of any overt scepticism concerning the reality of maleficium but rather a sign of critical concerns with particular aspects of the text's specific presentation of it. As Joseph Hansen has pointed out,

Institoris und Sprenger wussten natürlich ganz gut, dass sie - abgesehen von anderen damals noch im Fluss befindlichen Erörterungen - namentlich in zwei Fragen von Bedeutung eine Auffassung vertraten, die damals in theologischen und canonistischen Kreisen durchaus nicht allgemein anerkannt war. Die eine war die Frage nach der Möglichkeit und der Realität des Hexenflugs; sie beschäftigte eben damals die gelehrte Welt und erregte wegen ihrer Bedeutung für die Beurteilung der verhängnisvollen Theorie vom Hexensabbat die Gemüter für und wider. Die andere Streitfrage drehte sich um die im Malleus vertretene canonistische Ansicht, dass wegen des ganz besonders boshaften Charakters der von den Hexen ausgeübten Ketztereien die Inquisitoren auch reumütige, ihre Laster abschwörende Hexen dem weltlichen Arm zur Bestrafung überliefern, Hexen also unter allen Umständen dem Scheiterhaufen überantworten dürften, was sonst nur rückfälligen oder hartnäckigen Ketzern bevorstand. 244

With regards to the first point, nocturnal flight, the Malleus indeed refers to it, directly or indirectly, on at least eight occasions - I, Q.16, p. 86

facultatem computando." For further discussion, see Chapter Five. That opposition to Kramer's activities may not have been founded upon theological grounds alone; cf. Chapter Three.

244 Hansen, "Der Malleus Maleficarum, seine Druckausgaben und die gefälschte Kölner Approbation", pp. 157-8. 
[Schmidt, I, p. 200]; II, Q.1, c.2, p. 106 [Schmidt, II, pp. 29-30]; five times in II, Q.1, c.3, p. 110-16 [Schmidt, II, pp. 41-53]; II, Q.2, c.6, pp. 200-1 [Schmidt, II, pp. 252-3] - and to the Sabbat five times - twice in I, Q.16, p. 86 [Schmidt, I, p. 200]; twice in II, Q.1, c.2, pp. 104-8 [Schmidt, II, pp. 29-32]; and once in II, Q.1, c.3, p. 114 [Schmidt, II, p. 52]. Both concepts, however, remain crudely unsophisticated especially in light of the later elaborations of the witch manuals produced during the times of the great hunts of the sixteenth and seventeenth centuries. Kramer compounds nocturnal flight with somnambulism on at least two occasions 245 and at one point openly vacillates on the entire question. ${ }^{246}$ Although he mentions the employment of demonic animals as

245 Malleus, II, Q.1, c.3, p. 112 [Schmidt, II, p. 45] - "Verum quidem, quod non solum vigilantibus, sed dormientibus talia accidere possint, fateri necesse est: ut videlicet dormiendo per aeru localiter et coporaliter transferantur."; II, Q.2, c.6, pp. 200-1 [Schmidt, II, pp. 252-3] - "Patet et de quibusdam qui super tegulas domorum et aedificia altissima, somniando incedunt: nec quicquam eis obstare potest ad eorum transitum, tam in altum, quam in profundum: Et si propriis nominibus ab aliis circumstantibus vocantur, statim ad terram quasi collisi ruunt."

246 Malleus, II, Q.1, c.3, p. 115 [Schmidt, II, p. 52] - "Inter quas et illa in oppido Brisiaco interrogata a nobis, an ne phantastice et illusorie aut corporaliter possent transferri: respondit quod utroque modo. Si enim casa aliquo nollent corporaliter transferri, scire tamen vellent omnia quae in concione illa ab earum consodalibus agerentur, tunc talis ab eis servaretur modus, ut illa in nomine omnium Diabolorum ad latus sinistrum se reponeret ad cubitum: ex tunc quasi vapor quidum glaucus ex eius ore procederet. Unde singula quae ibi agerentur per lucide considerarent, si cero corporaliter transferri vellent, modum supradictum servare necesse esset."

Cf. also ibid., I, Q.16, p. 86 [Schmidt, I, p. 200], where a similar view is offered: "Nam si corporaliter, ut supra tactum est [sic], nolunt transferre, sed tantum imaginarie cernere, quae a consodalibus maleficis perpetrantur, reponere se habent ad sinistrum latus in nomine sui Diaboli et omnium Daemoniorum. Unde fit, ut eis singula imaginaria visione repraesentetur a simili. Si aliqua occulta scire pro vel aliis hominibus volent a Daemonibus, per somnia instruuntur, non per tacita, sed per expressa cum eis pacta inita. Nec iterum per quodcunque pactum, quocunque modo per aliquod sacrificium alicuius animalis, seu 
well as a flying unguent derived from the limbs of unbaptized children ${ }^{247}$, his accounts are vague and nondescript; he then proceeds to declare nocturnal flight to be both real and imaginary as witches were reputed to possess the power of conjuring visions of distant locales while remaining in bed. ${ }^{248}$ Kramer is equally vague on the question of the Sabbat. Although he explicitly mentions malefic gatherings of witches for the purposes of conducting some sort of satanic practices, he refrains from going into detail. Furthermore, at least two of these accounts are taken directly from Chapter Three of Book Five of Nider's Formicarius. ${ }^{249}$ The closest Institoris comes to taking a definite stand in the issue is in I, Q.16, where, in demonstrating the reality of the

sacrilega deprecationis, aut cultus etiam latriae exhibitionis, sed se ipsas in anima, et corpore Daemonibus offerentes, fidem penitus sacrilego ore abnegantes. Nec his contentae, etiam proprios aut alienos infantes Daemonibus offerunt, aut interimunt, de quibus supra habitum est."

The source for both these accounts is the same servant girl of Breisach who confessed to Institoris that she had been converted to diabolism by her aunt attending an initiation service conducted by fifteen young men clad in green and that she had flown great distances at night. Malleus, II, Q.1, c.2, p. 106 [Schmidt, II, pp. 29-30]. This account closely resembles the incident related to Institoris by an unnamed young virgin of straßburg who is approached by an elderly witch. Ibid., II, Q.1, c.1, pp. 102-3 [Schmidt, II, pp. 22-3]. See below, Chapters Three, Six and Seven.

247 Ibid., II, Q.1, c.3, p. 114 [Schmidt, II, p. 49].

248 Ibid., I, Q.16, p. 86 [Schmidt, I, p. 200]; II, Q.1, c.3, p. 115 [Schmidt, II, p. 52].

249 Nider, Formicarius, V, c.3, pp. 347-51 (See below Chapter Seven); Malleus, II, Q.1, c.2, pp. 106-7 [Schmidt, II, pp. 28-34]. The account in $I, Q .11$, p. 68. [Schmidt, I, p. 158], about a group of women meeting at night to kill and consume a kidnapped child is too vague to be taken as a direct reference to some sort of coherent idea of the sabbat. Furthermore, it is taken from the alleged verbal testimony of the Inquisitor of Como. See below, Chapter Three. 
demonic Pact, he stipulates that it is accompanied by some sort of ritualistic renunciation of Christianity, of ten followed by infanticide. ${ }^{250}$ It is obvious that Kramer's main concern here is to specify the conditions of the Pact, rather than the particularities of the specific ceremonial actions performed when taking an oath of homage to the Devil ${ }^{251}$, which is fully part of his more general strategy of diabolizing all forms of magical practice.

These apparent deviations from conventional demonological discourse have prompted many historians to minimize the historical import of the text. ${ }^{252}$ This view implicitly exaggerates the universality of such beliefs within fifteenth-century scholasticism. The Summis, commonly regarded by scholars as "one of the key documents in the history of witchcraft" ${ }^{253}$, completely omits any reference to either demonic flight or the Sabbat in its lengthy compilation of malefic transgressions. Furthermore, it misses the crucial point relating to the discursive strategy employed by Kramer in composing the treatise - that is, to demonstrate the necessary connection between heretical

250 "Nec iterum per quodcunque pactum, quocunque modo per aliquod sacrificium alicuius animalis, seu sacrilegae deprecationis, aut cultus etiam latriae exhibitionis, sed se ipsas in anima, et corpore Daemonibus offerentes, fidem.penitus sacrilego ore abnegantes. Nec his contentae, etiam proprios aut alienos infantes Daemonibus offerunt, aut interimunt, de quibus supra habitum est." Malleus, I, Q. 16, p. 86 [Schmidt, I, p. 200].

251 Malleus, II, Q.1, c.2, passim [Schmidt, II, pp. 26-41].

252 Cf. Cohn, Europe's Inner Demons, p. 225.

253 Robbins, The Encyclopedia of Witchcraft and Demonology, p. 263. 
diabolism and maleficium stereotyping the witch as a demonical deviant within a classificatory scheme structurally identical to that provided for the satanic heretic.

As for the second point, the unrestrained persecution of witches repentant or not, the Malleus does indeed appear to stand in direct contradiction to the general spirit of late medieval canon law. In those sections of the text where one would expect a discussion of the repentant witch ${ }^{254}$ one is instead confronted with resounding silence; the Malleus adapted only those passages from the Directorium inquisitorum of Nicholas Eymerich that relate to simple heresies, not to the more complex and later conception of satanic maleficium. ${ }^{255}$ On the whole, the Malleus adopts the same stance assumed by Nicholas Jacquier, who in his Flagellum haeriticorum of 1458, flagrantly violates the traditional canonical prescript that all genuinely repentant heretics automatically merited the clemency of life-imprisonment. ${ }^{256}$ Perhaps it is

254 III, Q.18, pp. 254-55 "De his, quae Iudex observare debet, tam in sententia interlocutoria, quam diffinitiva." [Schmidt, III, pp. 11014]; III, Q. 19, pp. 255-60 "Quot modis Iudex posit delatum habere suspectum, \& super quibus sententiam ferre possit." [Schmidt, III, pp. 114-24]; III, Q. 27, pp. 275-7 "Super modum sententiandi haeresim confessum, sed impoenitentem." [Schmidt, III, pp. 161-6]; III, Q. 28, pp. 277-80 "Super modum sententiandi haeresim confessam, seu relapsam, licet poenitentem." [Schmidt, III, pp. 166-74]; III, Q. 29, pp. 280-1 "Super modum sententiandi haeresim confessam, sed impoenitentem, non tamen relapsam." [Schmidt, III, pp. 174-7]; III, Q. 30, pp. 281-2 "Super haeresim confessam \& relapsum \& impoenitentem." [Schmidt, III, pp. 177-81].

$$
\begin{aligned}
& 255 \text { See below, Chapter Seven. } \\
& 256 \text { See below, Chapter Seven. }
\end{aligned}
$$


the Malleus's blatant opposition to this opinio communis - most likely a result of Kramer's Brixen fiasco -, that prompts the author of the "Apologia" to declare that the text's claim to orthodoxy is supported by the treatise's status as a mere compilation of previous authoritative pronouncements to which nothing substantial had been added. ${ }^{257}$ That this obviously highly qualified disclaimer failed in its objective is evidenced by the tepid endorsement of the first letter of approbation with its meagre four signatures.

Institoris, then, was in a position wherein he must have felt great pressure to secure maximum authoritative status for his text - the same quest for legitimacy that led to the inclusion of the Summis in every single printed edition of the Malleus. In numerous ways the University of Cologne was the perfect instrument for his needs. The most obvious, of course, was that Jacob Sprenger was a respected professor of the theology faculty, providing Kramer with both the legitimate connections he needed in order to obtain some form of legal authorization, as evidenced by the first letter, and the opportunities cynically to acquire illegal endorsement, as in the case of the second letter. Furthermore, the Dominican-Realist theologians of the university had displayed a long-standing concern with the problem of maleficium and this concern had undoubtedly captured Sprenger's own attention. Throughout the second half of

257 Hansen, "Der Malleus Maleficarum, seine Druckausgaben und die gefälschte Kölner Approbation vom Jahre 1487", p. 158. See below, Appendix A. 
the fifteenth century, allegations of witchcraft within the Lower Rhine region had begun to attract the notice of the secular authorities. Around 1435, a female transvestite imitating Joan of Arc had been tried and subsequently excommunicated in Cologne on charges of maleficium. ${ }^{258}$ From 1446 onwards, the town council of Cologne seriously began to prosecute Hexen and of ten turned to the theology faculty for assistance. In August 1456, a secular court tried two women for maleficium ${ }^{259}$; in 1483 a woman was sentenced to death for malefic practices, dying in prison as a result of torture ${ }^{260}$; in 1486 a man was accused of satanic magic ${ }^{261}$, and on 5 July of the same year the theology faculty petitioned the Duke of Jülich to take severe measures in suppressing the rash of hydromantic practices that had erupted within his holdings. ${ }^{262}$ In 1487 a mother and daughter ${ }^{263}$ were both buried alive on

258 Franken and Hoerner, Hexen: Die Verfolgung von Frauen in Köln, p. 14; Hansen, Quellen, pp. 458-9; Hansen, Zauberwahn, p. 424; Nider, Formicarius, v, C.8, pp. 385-6.

259 Franken and Hoerner, Hexen: Die Verfolgung von Frauen in Köln, p. 14; Hansen, Quellen, pp.566-9; Hansen, Zauberwahn, p. 432; Lea, A History of the Inquisition of the Middle Ages, III, p. 457; Lea, Materials Toward a History of Witchcraft, I, pp. 253-4.

260 Hansen, Quellen, p. 583; Hansen, Zauberwahn, p. 432.

261 Hansen, Quellen, p. 584; Pauls, "Zauberwesen und Hexenwahn am Niederrhein", p. 237.

262 Hansen, Quellen, p. 584.

263 Franken and Hoerner, Hexen: Die Verfolgung von Frauen in Köln, p. 15; Hansen, Quellen, p. 586; Cf. also Die Chroniken der Deutschen Städte, Vol. XIV Die Chroniken der Niederrrheinischen Städte: Cöln, Part III, p. 913. 
suspicions of sorcery; and in 1489 the university subjected the doctrines of the local astrologer Hartung Gernod to critical scrutiny, issuing a statement on 4 April calling for his arrest and interrogation by the Inquisition that included the names not only of Jacob Sprenger, but of Jacob de Straelen, Thomas de Scotia, and Udalricus Kridwiss as well. ${ }^{264}$ Thanks to the prolific activities of the Dominican members of the theology faculty, the reputation of Cologne as a regional centre of witch hunting had become so well established by the end of the century, that in 1491 the town council of Zutphen petitioned the magisterial court of Cologne for guidance concerning the application of torture to three suspected witches incarcerated at Lochem. ${ }^{265}$ Cologne's status had in fact far exceeded local repute and even received papal recognition. In 1479, Pope Sixtus IV sent a breve to the university, applauding the faculty's efforts in facilitating the persecution of Ketzer, Ketzerinnen, Zauberer, and Hexen. ${ }^{266}$

The university's judicial importance in the prosecution of witches was matched by its political role in the supervision and censorship of the publication of theological texts within the lower Rhineland territories. Immediately following the introduction of the printing press, the university had taken

264 Hansen, Quellen, pp. 503-6.

265 Hansen, " Der Malleus Maleficarum, seine Druckausgaben und die gefälschte Kölner Approbation vom Jahre 1487", p. 159.

266 There is apparently no existent copy of this breve in either Cologne or Rome. The only reference that I have so far been able to locate is a note about an entry in the Dekanatsbuch for 1515, provided by Hansen, ibid., pp. 160-1. 
measures to prevent the Rhenish market from being flooded with unorthodox religious material, imposing a series of strict censorship guidelines. Cologne thus rapidly established itself as one of the leading sites of innovation of the censorship regulations employed by regional ecclesiastical institutions. The curia exploited to the full the political capital inherent in this situation, utilizing the Dominican-Realist theology faculty as a bulwark against the dissemination of Nominalist or otherwise subversive heterodox notions. On 18 March 1479, Sixtus IV, in response to a report sent to him from Cologne concerning censorship procedures ${ }^{267}$, issued a breve in which he praised the zeal of the theology faculty in thwarting the printing and distribution of heretical treatises and granted the university the absolute authority to employ both ecclesiastical censorship as well as all other means in preventing the dissemination of heretical concepts through printed works. In addition, the university was empowered to act against those printers who had moved from Cologne in order to avoid the censorship ban, by petitioning both the bishops as well as the secular authorities of the communities harbouring the fugitive publishers. ${ }^{268}$ From the research of Joseph Hansen we can see that the

267 According to Hansen, no copy of the university's report to the curia is held in either Cologne or Rome. Ibid., p. 138.

268 Ibid., p. 138. No original version of this breve appears to have survived. Reprinted copies are contained in Bocking, ulrici Hutteni Opera, Suppl. I, p. 358; Bianco, Die alte Universität Köln, I, p. 207a; Hartzheim, Prodromus, I, c, p. 8. Cf. Ennen, Die Incunablen der Kölner Staatsbibliothek, p. XxII. 
great number of books published within the Rhineland territories and bearing the imprint of inspection by the Cologne theology faculty reveals the extent to which the university had been successful in subjecting publishers to its imperious grasp. Such dominance was, however, not to last. On 17 November 1487 Innocent VIII, in his bull Inter multiplices, the first papal decree regarding the general laws of censorship, ordered all printers throughout Christendom on pain of excommunication to refrain from publishing any material that did not enjoy full episcopal approval. It was also rendered mandatory for all printers to submit to the proper ecclesiastical authorities extensive lists of all new publications as well as used type prints, so that earlier editions of censored works could be identified and confiscated. 269 Thus, by the end of the 1480 s, the authoritative status of the theology faculty of Cologne as a regional centre of theological censorship had undergone a sharp decline, because responsibility had largely been transferred to the local episcopal courts. In May 1487, however, a letter of approbation from the university still managed to convey upon the work bearing it a unique prestige within the academic world - a prestige doubtlessly coveted by frater Henricus Institoris.

269 Hansen, "Der Malleus Maleficarum, seine Druckausgaben und die gefälschte Kölner Approbation vom Jahre 1487", p. 138. The original copy of the Inter multiplices is reprinted in statuta seu decreta provincialium et diocesanorum syndorum ecclesie Coloniensis, (1554), fols. 280-1. 
The reasons that underlay Kramer's clumsy and rather desperate efforts in the forgery of 19 May 1487 now become clear. Continuously impeded in his general efforts to secure the condemnation of satanic malefactors even when armed with the papal blessing of the Summis desiderantes, and frustrated by his embarrassing failure in the Tirol, he decided to exploit to the full his relationship to his reputed co-author Jacob Sprenger in order to optimize the strength of his judicial and political position in any and all future witcheraft prosecutions. It was this essentially pragmatic juro-political concern, rather than any radical or even unorthodox deviation from some well-established theological dogma that drove Kramer to seek for his book the full approval by the Cologne theology faculty and to commit a blatantly criminal of fence in order to obtain it. ${ }^{270}$ The background to Institoris' political career as a

270 From 1907 to 1908 a fierce polemical fight was waged between Joseph Hansen and Nikolaus Paulus over this very question concerning the presumed forgery of the notary instrument. Paulus initiated the proceedings with a spirited attack on Hansen's position, published as the essay "Ist die Kölner Approbation des Hexenhammers eine Fälschung?" in Historisches Jahrbuch (1907). Among other objections, Paulus cast doubt upon Hansen's view by arguing that, since Arnold Kolich continued to serve as a notary for the University of Cologne and since there was no immediate legal action undertaken by the theology faculty, there are reasonable grounds for not regarding the approbation as fraudulent [p. 873]. Furthermore, Paulus raises the objection that, since the author(s) of the Malleus already possessed letters of support from both the Emperor and the Pope, there would have been no practical motivation for them to have engaged in a forgery [p. 876]. Hansen wasted no time in issuing a fierce rebuttal in the Westdeutsche Zeitschrift für Geschichte und Kunst (1907), entitled "Der Hexenhammer, seine Bedeutung und die gefälschte Kölner Approbation vom Jahre 1487". In blatant contradiction to Paulus, Hansen successfully demonstrates that Kolich was in fact at no time employed in any official capacity as a notary for the university, Paulus' erroneous conclusion to the contrary being the result of a slovenly utilization of archival resources [pp. 394-5]. The lack of any apparent judicial proceedings against the two forgers Kolich and Institoris - can be explained by the great immediate popularity and practical success of the text; in Hansen's view the 
practising inquisitor in the field must therefore now be examined in more detail.

incorporation of the Malleus's basic tenets into the academic opinion of the theological community would naturally mitigate against any legal prosecution [p. 400]. Finally, Institoris' need for even greater authoritative legitimacy is indicative of the ferocity of the opposition that he encountered. There is conclusive evidence that Maximilian's diploma and the papal summis proved themselves ineffectual in the face of local resistance and that the actual composition of the Malleus itself was undertaken primarily as a means of undermining such opposition [pp. 397, 402; see below, Chapter Three]. After this point, the quality of the rhetorical exchange rapidly deteriorates. In his essay "Zur Kontroverse über den Hexenhammer" in Historisches Jahrbuch (1908), Paulus concedes Hansen's point on the question of Kolich's employment by Cologne University [pp. 559-60]; the remainder of the essay, however, is little more than a stubborn recapitulation of his previous argument [pp. 562-74]. The concluding chapter to the debate, Hansen's "Die Kontroverse über den Hexenhammer und seine Kölner Approbation vom Jahre 1487", printed in the Westdeutsche Zeitschrift für Geschichte und Kunst (1908), suffers from a similar malaise of dogmatism, with Hansen authoritatively reciting his pre-established position [passim]. 


\section{CHAPTER THREE:}

\section{INSTITORIS AS INQUISITOR.}

A detailed examination of the judicial and inquisitorial activities of Heinrich Institoris must necessarily touch upon a series of problems connected with any study of the status and function of the Inquisition in late medieval Germany, problems which themselves are intimately linked to that radical dispersion of the sites and effects of power and knowledge which has already been alluded to on several occasions in this dissertation. It has been customary for historians to refer to all ecclesiastical judicial agents as constituting the uniform institution of "the Inquisition". In truth, such practice blurs objective and vital differences between the various kinds of judges delegated to conduct trials in accordance with inquisitorial procedures - episcopal officiales, papal notaries and legates, and, later on, secular magistrates. ${ }^{1}$ Any reference to a single, unitary medieval Inquisition, especially with regards to the German national context of the fourteenth and fifteenth centuries, is anachronistic, the Inquisition not becoming an historical reality ${ }^{2}$ until the advent of the Roman

1 "There was no institutional bond that united all papal and episcopal inquisitors within a single agency. To refer to all such inquisitors as constituting 'the Inquisition' is to engage in an abstraction, and a dangereously misleading one." Kieckhefer, The Repression of Heresy in Medieval Germany, pp. 3-4. Cf. also Given, "The Inquisitors of Languedoc and the Medieval Technology of Power", p. 339 .

2 Kieckhefer, The Repression of Heresy in Medieval Germany, p. 10. 
and Spanish models of inquisitorial organization of the sixteenth century. One does not have entirely to assent to the extreme sceptical outlook inherent in Richard Kieckhefer's position ${ }^{3}$ in order to perceive how such considerations may be applied in a useful fashion in obtaining insights into the political career of Institoris, one marked by dissent, resistance, failure, and the successful challenging of traditional forms of juro-ecclesiastical authority.

According to Kieckhefer, the German medieval inquisitor, unlike many of his contemporaries in France or Italy, was often a highly marginal figure politically and judicially due to the absence of a single and unitary centralized politico-ecclesiastical administrative apparatus. ${ }^{4}$ The establishment of papal inquisitors within Germany did not occur on a regular basis until the second half of the fourteenth century. ${ }^{5}$ In 1372 Gregory IX guaranteed the continuity of what little inquisitorial authority there was by assigning the responsibility for the routine appointment of five Dominican inquisitors to the Master and Provincial of the order's southern German territories. By 1399, however, thanks to intense regional disputes within the order, the original papal decree was reversed, authority for appointments tranferred to the north German Provincial.

\footnotetext{
3 Cf. Hamilton, The Medieval Inquisition, p. 9.

4 "There was no structure of authority to ensure regularity or propriety of function." Kieckhefer, The Repression of Heresy in Medieval Germany, p. 4.

5 Ibid., p. 23.
} 
Soon responsibility for appointments passed altogether out of the hands of the German Dominicans to the vicar-general in Rome, although the counsel of the German superiors no doubt proved to be influential. ${ }^{6}$ Normally apointed by the vicar-general, although ultimately responsible to the papal curia, or, even more often, to the person of the pope himself ${ }^{7}$, German inquisitors "entered into two highly centralized ecclesiastical institutions, but not a specifically judicial institution that could be labelled 'the Inquisition'."8 Deprived of a central administrative network, inquisitors usually functioned as "autonomous agents, without institutional provisions to direct them toward interaction". 9 Not surprisingly, when the official term Officium inquisitionis heretice pravitatis came into common usage in the fourteenth century, rather than denoting a specific administrative apparatus with clearly defined powers and procedures, the phrase conveyed a more general function or jurisdiction with which an individuai inquisitor was invested. 10

6 Ibid., p. 24.

7 Pitz, "Diplomatische Studien zu den Päpstlichen Erlassen über das Zauber- und Hexenwesen", passim.

4.

8 Kieckhefer, The Repression of Heresy in Medieval Germany, p.

9 Ibid., p. 4.

10 Ibid., pp. 4-5. "The 'office of the inquisition' was the function of carrying out inquisitorial justice against heretics, rather than an institution established for this purpose. On rare occasions one finds contexts that do suggest that contemporaries may have been thinking of either an institution or an abstraction when they used this term, but this atypical usage is inconclusive. In these circumstances 
This general lack of adequate administrative support had a decisively negative impact upon German inquisitorial activity in at least two major ways. Firstly, the absence of proper institutional control of ten impeded inquisitorial efforts by allowing papal delegates frequently to enmesh themselves in power struggles with local episcopal and secular authorities regarding questions of legal jurisdiction and judicial restraint. Although there is no convincing evidence that either episcopal officials or lay magistrates ever opposed inquisitorial activities and procedures as $\operatorname{such}^{11}$ - canon law explicitly required that bishops and papal inquisitors work in close cooperation so as to avoid procedural irregularity ${ }^{12}$ - there were numerous instances of individual resistance offered by local authorities revolving around accusations of either misuse or of excessive application of techniques by specific inquisitors in specific instances. ${ }^{13}$ That such political tensions played a decisive role in the development of Kramer's inquisitorial career can be seen with regard to the background to the promulgation of the Summis desiderantis which I have

it would perhaps be advisable to avoid speaking of even papal inquisitors as if they formed a suprapersonal agency, or an Inquisition." Ibid., p. 5 .

11 Ibid., p. 50 .

12 Ibid., p. 41 .

13 Ibid., p. 50. "When inquisitors met resistance, it was almost always because they had exceeded the bounds of commonly recognized regular and justifiable prosecution." Ibid., p. 3. Cf. also Given, "The Inquisitors of Languedoc and the Medieval Technology of Power", pp. 356-8. 
This general lack of adequate administrative support had a decisively negative impact upon German inquisitorial activity in at least two major ways. Firstly, the absence of proper institutional control of ten impeded inquisitorial efforts by allowing papal delegates frequently to enmesh themselves in power struggles with local episcopal and secular authorities regarding questions of legal jurisdiction and judicial restraint. Although there is no convincing evidence that either episcopal officials or lay magistrates ever opposed inquisitorial activities and procedures as such ${ }^{11}$ - canon law explicitly required that bishops and papal inquisitors work in close cooperation so as to avoid procedural irregularity ${ }^{12}$ - there were numerous instances of individual resistance offered by local authorities revolving around accusations of either misuse or of excessive application of techniques by specific inquisitors in specific instances. ${ }^{13}$ That such political tensions played a decisive role in the development of Kramer's inquisitorial career can be seen with regard to the background to the promulgation of the Summis desiderantis which I have

it would perhaps be advisable to avoid speaking of even papal inquisitors as if they formed a suprapersonal agency, or an Inquisition." Ibid., p., 5 .

11 Ibid., p. 50 .

12 Ibid., p. 41 .

13 Ibid., p. 50. "When inquisitors met resistance, it was almost always because they had exceeded the bounds of commonly recognized regular and justifiable prosecution." Ibid., p. 3. Cf. also Given, "The Inquisitors of Languedoc and the Medieval Technology of Power", pp. 356-8. 
discussed in Chapter Two. The Bull was obviously composed in such a way as to anticipate and guard against any possible canonical and/or theological objection that might conceivably be put forward by anyone who found himself/herself subject to the inquisitorial jurisdiction of Institoris, legal safeguards that act as a distinguishing feature of a Fakultät of which the Bull was merely a glamorized version. ${ }^{14}$ Similar power struggles are (indirectly) attested to by numerous other documents resulting from Kramer's judicial activities, most notably the existent corpus of material from the Brixen proceedings, to be discussed below.

Secondly, papal inquisitorial conflict with regional authorities was inextricably linked to the focusing of their efforts on marginal religious deviants, including beghards, beguines, sorcerers, and witches, i.e. those elements which posed little danger to the Church. ${ }^{15}$ The sheer vastness of the geographical expanse of the ecclesiastical principalities of Germany rendered effective inquisitorial supervision virtually impossible, as opposed to

14 Pitz, "Diplomatische Studien zu den Päpstlichen Erlasssen über das Zauber- und Hexenwesen", p. 55. See above, Chapter Two.

15 Kieckhefer, The Repression of Heresy in Medieval Germany, p. 5. The selection of beghards or beguines for special attention seems to have largely been a result of a confused terminology resulting from the Council of Vienna of 1312, which errnoneously linked the beghards to the suspected Heresy of the Free Spirit. "In legal and inquisitorial usage, therefore, the words acquired a highly specific meaning: a beghard or beguine was someone who subscribed to a specific set of heterodox principles. The result of this ambiguity was disastrous, for anyone who could be labelled a beghard or beguine... in the excessively strict sense... would be subject to inquisitorial proceedings." Ibid., p. 21; Lerner, The Heresy of the Free Spirit, pp. 79-84, 229. 
conditions in southern Europe where inquisitors were generally responsible for only a single diocese, or, at most, two or three. ${ }^{16}$ More importantly, within the late medieval German context, heresy did not come to be perceived as a dire threat to the religious establishment ${ }^{17}$; rather, blasphemers and Jews tended to occupy the attention of those ecclesiastical authorities concerned with religious deviancy.

The problem in Germany was one of scattered heretics who for the most part remained effectively underground. There was no sense of urgency in their excommunication; there were fewer spectacular gains to be made. ${ }^{18}$ In these circumstances it is not surprising that the papal inquisitors, subject to no institution, failed to attend even to those heretics that did exist, and either dissipated or misused their inquisitorial powers. 19

The effective measures that were imposed against heretical groups, mainly Waldensians and Hussites, were undertaken almost entirely by regional episcopal authorities. Diocesan inquisitors possessed a number of distinct advantages over their papal counterparts - episcopal authorities did not have as wide an array of responsibilities, administrative or academic, as did papal representatives, and they enjoyed far greater familiarity with the immediate area of their 5.

16 Kieckhefer, The Repression of Heresy in Medieval Germany, p.

17 "If one examines the sources of the period - literary as well as documentary - one finds that the problem of heresy was only to a very minor degree in the consciousness of Germans." Ibid., p.6.

18 Mainly in terms of financial gains through confiscation by the emperor. Ibid., p. 16.

19 Ibid., p. 6. 
jurisdiction. ${ }^{20}$ As a result

episcopal inquisitors did not need institutional support to be kept active and responsible in the prosecution of heretics, because they had the guidance and aid of their superiors and colleagues within the diocese. The lack of institutional sophistication most clearly affected the papal inquisitors in a country such as Germany, where they were allowed to dissipate their powers in inactivity or in arbitrary, dubious, or frivolous prosecution. And it was when such inquisitors proceeded in this fashion that they were likely to arouse opposition. 21

The difficulties encountered by Institoris in his own career as an inquisitor mirrored in a striking fashion the inherent ambiguities of the general status of the papal inquisitor within late medieval Germany. In addition to the political tensions already referred to, it was Kramer's personal devotion to the prosecution of suspected witches, most notably at Innsbruck, that brought into sharp relief, in microscopic form, the various sorts of political challenges and sites of resistance likely to be encountered by the papal representative of inquisitorial justice. These challenges and this resistance centered on the problem of the transformation of suspected local witches into stereotypical satanic heretics susceptible to the provisions of inquisitorial justice.

20 Ibid., pp. 8-9.

21 Ibid., pp. 8-9. 


\section{1. Institoris in the Field.}

Kramer's inquisitorial activities from the years $1481 / 2$ to 1486 are extremely difficult to trace with detailed accuracy ${ }^{22}$ because of the general dearth of documentary evidence. Although we know from the indulgence granted to the priory of Schlettstadt on 31 October 1483 that Institoris had been active as an inquisitor for some time, the letter specifies neither the exact locale nor the extent of Kramer's judicial machinations. ${ }^{23}$ Indeed, from 25 February 1483 to August 1485, the date of the commencement of the witch trials at Innsbruck, no evidence is available pertaining to Kramer's place of residence at

22 I have been largely unsuccessful in uncovering original primary material pertaining to the inquisitorial activity of Heinrich Institoris. My own work in Munich and in Bavaria from 1986-7 found little in the way of new archival material. Archivists such as Dr. Franz-Heinz Hye of the Stadtarchiv Innsbruck, Dr. Christian Fornwagner of the Landesarchiv Tirol, and Dr. Helmut Maurer of the Stadtarchiv Konstanz, have all testified to the lack of available documentation. Dr. Heide Dienst of the Institut für Österreichische Geschichtsforschung in Vienna, as well as Dr. Andreas Blauert of the University of Constance, authors of the most recent works on fifteenthcentury persecutions in the German Alpine regions were also unable to provide any additional references to new material. The work of Annette von Laer on the witch prosecutions in Constance, the most pivotal region of Kramer's activities, has likewise failed to produce any new evidence - indeed, of any indication of Institoris' presence there at all. On a more positive note, I have been able to obtain considerable material pertaining to the two most notorious and best documented witch trials mentioned within the Malleus, those at Ravensburg and at Innsbruck. Accordingly, the main body of this chapter has been constructed with these limitations in mind.

23 Reprinted in Hansen, Quellen, pp. 21-4. See above, Chapter Two. 
any given time. ${ }^{24}$ It appears unlikely, for example, that Kramer was at all active in Bavaria during this time, as both imperial and princely opposition to the papacy would have rendered conditions exceptionally inhospitable for a papal inquisitor $^{25}$ - a deduction apparently borne out by the text's omission of any reference to that territory. ${ }^{26}$

On the whole one is strongly inclined to rely primarily albeit not exclusively upon the evidence provided by the Malleus itself. W i t h f e w exceptions, the Malleus is maddeningly elusive in regards to the time and place of the events which it purports to describe. Altogether, the text cites malefic happenings in no fewer than thirteen different dioceses - Augsburg 27 , Basel $^{28}$, Brixen $^{29}$, Constance ${ }^{30}$, Edua $^{31}$, Freising $^{32}$, Lausanne $^{33}$, p. 404 .

24 Müller, "Heinrich Institoris, der Verfasser des Hexenhammers",

25 Riezler, Die Geschichte der Hexenprozesse in Bayern, p. 6.

26 Except for a brief account of a mass burning of heretics at Regensburg in Malleus, III, Q.15, p. 248 [Schmidt, III, pp. 95-6] an incident which seemingly did not involve Kramer. Hansen, Zauberwahn, p. 424. See below.

27 Malleus, II. Q.1, c.1, pp. 101-2 [Schmidt, II, p. 20].

28 Ibid., II, Q.1, c.2, p. 110 [Schmidt, II, p. 39]; II, Q.1, c.11, p. 147 [Schmidt, II, p. 126]; II, Q.1, c.13, p. 152 [Schmidt, II, p. 137].

29 Ibid., II, Q.1, c.1, p. 103 [Schmidt, II, p. 24]; II, Q.1, c.12, pp. 148-51 [Schmidt, II, pp. 128-34].

30 Ibid., II, Q.1, c.3, p. 114 [Schmidt, II, p. 49]; II, Q.1, c. 4, p. 119 [Schmidt, II, pp. 60-1]; II, Q.1, c.6, p. 127 [Schmidt, II, p. 78]; II, Q.1, c.11, p. 148 [Schmidt, II, p. 127]; II, Q.1, c.16, p. 164 [Schmidt, II, p. 164]; II, Q.2, p. 174 [Schmidt, II, p. 189]. 


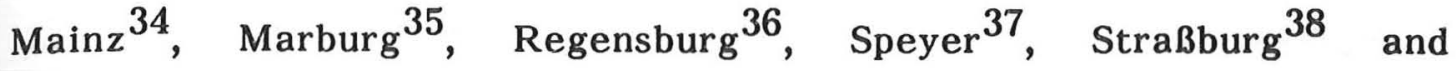
Worms ${ }^{39}$. Of these references, the alleged occurrences at both Edua and Lausanne are drawn directly from earlier accounts provided by Nider in the Formicarius $^{40}$ while the poltergeist outbreak at Mainz during the reign of Louis II is taken from the Speculum Historiale of Vincent of Beauvais. ${ }^{41}$ Therefore, in only nine of the aforementioned dioceses would it appear at all possible that the author could have possessed some immediate first-hand knowledge of the events described. ${ }^{42}$ Furthermore, of these nine, it is from

\footnotetext{
31 Ibid., II, Q.1, c.2, p. 106 [Schmidt, II, p. 31].

32 Ibid., II, Q.1, c.3, p. 112 [Schmidt, II, p. 44].

33 Ibid., II, Q.1, c.6, p. 126 [Schmidt, II, p. 77].

34 Ibid., II, Q.1, c.11, p. 145 [Schmidt, II, p. 120].

35 Ibid., II, Q.1, c.10, p. 143 [Schmidt, II, p. 115 - Schmidt
} erroneously refers to the "stadt Marburg"].

36 Ibid., III, Q.15, p. 248 [Schmidt, III, p. 95]. Erroneously cited as "Dioecesi Ratisbonensi".

37 Ibid., III, Q.34, p. 290 [Schmidt, III, p. 210].

38 Ibid., II, Q.1, c.1, pp. 102-3 [Schmidt, II, p. 22]; II, Q.1, c. 2, p. 106 [Schmidt, II, p. 30]; II, Q.1, c.9, pp. 136-7 [Schmidt, II, p. 99]; II, Q.1, c.13, p. 152 [Schmidt, II, p. 137].

39 Ibid., II, Q.1, 'c.16, p. 163 [Schmidt, II, p. 163]. Seven.

40 Nider, Formicarius, V, c.3, pp. 349-51. See below, Chapter

\footnotetext{
41 Summers, The Malleus Maleficarum, p. 135.

42 Regensburg is, of course, disqualified as it seems unlikely that Kramer participated directly in the executions. See above,
} Chapter Two. 
Mainz ${ }^{34}$, Marburg ${ }^{35}$, Regensburg ${ }^{36}$, Speyer $^{37}$, Straßburg $^{38}$ and Worms ${ }^{39}$. Of these references, the alleged occurrences at both Edua and Lausanne are drawn directly from earlier accounts provided by Nider in the Formicarius $^{40}$ while the poltergeist outbreak at Mainz during the reign of Louis II is taken from the Speculum Historiale of Vincent of Beauvais. ${ }^{41}$ Therefore, in only nine of the aforementioned dioceses would it appear at all possible that the author could have possessed some immediate first-hand knowledge of the events described. ${ }^{42}$ Furthermore, of these nine, it is from

31 Ibid., II, Q.1, c.2, p. 106 [Schmidt, II, p. 31].

32 Ibid., II, Q.1, c.3, p. 112 [Schmidt, II, p. 44].

33 Ibid., II, Q.1, c.6, p. 126 [Schmidt, II, p. 77].

34 Ibid., II, Q.1, c.11, p. 145 [Schmidt, II, p. 120].

35 Ibid., II, Q.1, c.10, p. 143 [Schmidt, II, p. 115 - Schmidt erroneously refers to the "stadt Marburg"].

36 Ibid., III, Q.15, p. 248 [Schmidt, III, p. 95]. Erroneously cited as "Dioecesi Ratisbonensi".

37 Ibid., III, Q.34, p. 290 [Schmidt, III, p. 210].

38 Ibid., II, Q.1, c.1, pp. 102-3 [Schmidt, II, p. 22]; II, Q.1, c.2, p. 106 [Schmidt, II, p. 30]; II, Q.1, c.9, pp. 136-7 [Schmidt, II, p. 99]; II, Q.1, c.13, p. 152 [Schmidt, II, p. 137].

39 Ibid., II, Q.1, c.16, p. 163 [Schmidt, II, p. 163]. Seven.

40 Nider, Formicarius, V, c.3, pp. 349-51. See below, Chapter

41 Summers, The Malleus Maleficarum, p. 135.

42 Regensburg is, of course, disqualified as it seems unlikely that kramer participated directly in the executions. See above, Chapter Two. 
the dioceses of Brixen, Constance, Speyer, and Straßburg that the majority of cases are drawn. In addition to an occurence of demonic leprosy somewhere in the general area of Alsace and Lorraine ${ }^{43}$, four communities in the diocese of Basel are explicitly mentioned - Breisach ${ }^{44}$, Buchel ${ }^{45}, \mathrm{Dann}^{46}$, and Oberweiler $^{47}$. Brixen is referred to on numerous occasions ${ }^{48}$, as Innsbruck was the site of the largest and best documented of Kramer's witch trials. A total of eight towns in the diocese of Constance are cited - Enningen ${ }^{49}$, Freiburg $50, \quad$ Fürstenburg ${ }^{51}$, Hagenau $^{52}$, Lindau $^{53}$, Mersburg $^{54}$,

43 Malleus, II, Q.1, c.11, p. 147 [Schmidt, II, p. 126].

44 Ibid., II, Q.1, c.2, p. 106 [Schmidt, II, p. 29]; II, Q.1, c.3, p. 115 [Schmidt, II, p. 52]; II, Q.1, c.11, p. 148 [Schmidt, II, p. 127$]$

45 Ibid., II, Q.1, c.2, p. 110 [Schmidt, II, p. 40].

46 Ibid., II, Q.1, c.13, p. 152 [Schmidt, II, p. 137].

47 Ibid., II, Q.1, c.2, p. 110 [Schmidt, II, p. 39].

48 Ibid., II, Q.1, c.1, pp. 103-4 [Schmidt, II, p. 24]; II, Q.1, c.12, p. 151 [Schmidt, II, p. 134].

49 Ibid., II, Q.2, p. 174 [Schmidt, II, p. 189].

50 Ibid., II, Q.1, c.11, p. 148 [Schmidt, II, p. 127].

51 Ibid., III, Q.17, p. 254 [Schmidt, III, p. 110].

52 Ibid., II, Q.1, c.2, p. 109 [Schmidt, II, p. 37]; III, Q.15, pp. 247-8 [Schmidt, III, p. 94].

53 Ibid., II, Q.2, c.3, p. 186 [Schmidt, II, p. 216].

54 Ibid., II, Q.1, c.6, p. 127 [Schmidt, II, p. 78]. 
Waldshut ${ }^{55}$, and Ravensburg ${ }^{56}$ (often erroneously referred to under the Latin name for Regensburg, "Ratisbon"57), the most frequently cited and extensively discussed witch trial in the Malleus - as well as reported happenings occuring in the territories of the Black Forest ${ }^{58}$ and around Schloß Hohenzollern ("Hohenzorn") 59 . At one point Kramer even claims Constance to be the diocese most heavily infested with maleficia, not because of the greater number of witches concentrated there, but, significantly, because it was the diocese that had been most thoroughly sifted by the inquisitors.

Terte etiam experientia didicimus plurimas tales maleficas per diocesim Constantiensem existere: non quod ipsa prae aliis diocesibus sit infecta, cum hoc genus infidiae serpat per omnes dioceses, et heu totum mundam infecisse videtur: sed quia ipsa diocesis amplius elaboratu fuit. ${ }^{60}$

There is only one reference to the diocese of Speyer, and that in relation to the community of Zunhofen ${ }^{61}$, but there are four references to the town

\footnotetext{
55 Ibid., II, Q.1, c.3, p. 114 [Schmidt, II, p. 49].

56 Ibid., II, Q.1, p. 96 [Schmidt, II, p. 5]; II, Q.1, c.1, p. 102 [Schmidt, II, p. 21]; II, Q.1, c.2, p. 109 [Schmidt, II, p. 37]; II, Q.1, c.4, p. 119 [Schmidt, II, p. 60]; II, Q.1, c.7, p. 127 [Schmidt, II, p. 78]; II, Q.1, c.14, pp. 158-9 [Schmidt, II, p. 152]; II, Q.1, c.15, pp. 161-2 [Schmidt, II, pp. 157-60].

57 Ibid., II, Q.1, p. 96 [Schmidt, II, p. 5]; II, Q.1, c.1, p. 102 [Schmidt, II, p. 21]; II, Q.1, c.2, p. 109 [Schmidt, II, p. 37].

58 Ibid., II, Q.1, c.11, p. 148 [Schmidt, II, p. 127].

59 Ibid., II, Q.1, c.16, p. 164 [Schmidt, II, p. 164].

60 Ibid., II, Q.2, p. 174 [Schmidt, II, p. 189].

61 Ibid., III, Q.34, p. 294 [Schmidt, III, p. 210].
} 
itself $^{62}$. Finally, three communities within the diocese of Straßburg are named - Fiessen ${ }^{63}$, Schlettstadt ${ }^{64}$, and Zabern ${ }^{65}$. As Institoris was Predicator generalis for the diocese of Straßburg as well as Inquisitor haereticae pravitatis for the whole of the German Dominican province, as there is no record of any other papal inquisitor being active in Upper Germany during this time ${ }^{66}$, and as, furthermore, all the dioceses and communities mentioned above are situated within this region, it appears reasonable to conclude that many of these accounts of alleged maleficia contained in the Malleus, unless identifiable otherwise, could well have been derived in some fashion from the personal experience of Heinrich Institoris - as has already been shown, not the most reliable of sources.

A more detailed discusson of these actual judicial proceedings initiated by Institoris himself is, once again, severely hampered by the apparently general lack of substantive material - it appears as though the Malleus itself should be regarded as the main source of information concerning the relevant trials. Even

62 Ibid., I, Q.18, p. 91 [Schmidt, I, p. 214]; II, Q.1, Introductio, p. 96 [Schmidt, II, p. 7]; III, Q.13, p. 242 [Schmidt, III, p. 80]; III, Q.34, p. 294 [Schmidt, III, p. 210].

63 Ibid., II, Q.1, c.14, p. 159 [Schmidt, II, p. 153].

64 Ibid., III, Q.16, p. 251 [Schmidt, III, p. 103].

65 Ibid., II, Q.1, c.13, p. 151 [Schmidt, II, p. 135]. p. 402 .

66 Müller, "Heinrich Institoris, der Verfasser des Hexenhammers", 
Joseph Hansen's Quellen und Untersuchungen zur Geschichte des Hexenwahns,

normally a cornucopia of pertinent information, has only this to say regarding

Kramer's inquisitorial investigations for the whole of the diocese of Constance.

43. 1482-86, Diocese Konstantz (besonders Ravensburg und Umgegend.) Die Inquisitoren Heinrich Institoris und Jacob Sprenger, die Verfasser des Hexenhammers, führen zahlreiche Hexenprozesse und verurtheilen 48 Hexen zur Auslieferung an den weltlichen Arm; sie sterben auf dem Scheiterhaufen. Vgl. Malleus Maleficarum II, 1c.4 (ausg. von 1669) S.95, $119,158,174) .67$

Richard Kieckhefer, in his "calendar" of the witch trials, composed seventy-five

years later, provides a simliar entry.

1482-6, diocese of Constance: 48 persons tried for witchcraft by Henry Institoris (including 8 mentioned below, 1484 Ravensburg). S.: Sprenger and Institoris Malleus Maleficarum, (Lyon, 1669) 95, 119, 122, 158, 174 (Summers ed. 91ff., 111, 114, 146, 160); cited in Hansen, Quellen, 500. Summers erroneusly translates place name as Ratisbon (or Regensburg). 68

The source for both references is a single, very ambiguously worded passage in

II, Q.1, c.4, p. 95 [Schmidt, II, pp. 60-1].

Quotquot enim a nobis seculari brachio ad puniendum relictae fuerunt in variis Dioecesibus, praecipiae in Constantiensi, et in oppido Ravenspurg. multis annis his inhaeserunt spurcitiis certis sub vigesimo, aliis sub duodecimo, aut sub trigesimo anno, et seper cufidei abnegatione, in toto vel in parte: tertes sunt ibidem omnes incolae. Demptis enim secrete poenitentibus, et ad fidem reversis, non minus quam quadraginta et octo in quinque annis igni traditae fuerunt: nec tamen illis accommodata vides, quantum sponte reversis ad poenitentiam, credulitas adhibita fuit: omnibus in hoc concordantibus, quod huiusmodi spurcitiis in augmentum

67 Hansen, Quellen, p. 500.

68 Kieckhefer, The European Witch Trials, p. 141. 
huius perfidiae habent instistere. De quibus etiam, sigillatim in secunda parte operis, ubi eorum particularia opera describentur, tractabitur, obmittendo ea, quae et socius noster, Inquisitor Cumanus in Comitatu Burbie peregit, qui et in spatio unus anni, qui fuit Millesimus quadringentesimus octuagesimus quintus, quadriginta et unam maleficam comburi fecit: Et omnibus publice asserentibus, ut dictum est, illis spurcitiis Diabolicis inhaerisse. Constant ergo omnia, aut visus vel auditus propria experientia, aut fide digorum relatibus.

It is necessary to analyse this passage in some detail as it casts crucial light upon Kramer's judicial activities. In the first place, it fails to be borne out by the existent documentary material. Annette von Laer, who has conducted the most recent work on the prosecution of witches in fifteenth-century Constance, has been unable to uncover any trace of the inquisitor's activities within the community. 69 Even though she makes extensive usage of the available council books and town chronicles ${ }^{70}$, von Laer is still forced to rely on the Malleus itself for information about Institoris. ${ }^{71}$ Furthermore, those sources which von Laer utilizes indirectly invalidate the inquisitor's claim. An intense

69 "Obwohl das Wirken des Inquisitors von $1482-1486$ in der Diözese Konstanz im Hexenhammer und an anderen stellen belegt ist, gibt es weder in Prozeßakten noch in sonstigen Schriften Hinweise darauf, daß dieser auch in der Diözesan-Metropole seinen Einfluß geltend machte." von Laer, "Die spätmittelalterlichen Hexenprozesse in Konstanz und Umgebung", pp. 24-5.

70 "Die Quellenbasis, von der ausgehend ein Einblick in die Hexenprozesse im spätmittelalterlichen Konstanz vermittelt werden soll, besteht weitgehend aus den Amtsbüchern der Stadt. Es sind Bücher, die entstanden sind aus Verwaltungshandlungen und Geschäftsbedürfnissen der Stadtbürger, nämlich den im Stadtarchiv liegenden Rats-, Straf- und Steuerbüchern. Des weiteren wurden Stadtchroniken herangezogen." Ibid., p. 15.

71 "Als weitere Quelle dient der aus der Feder von Heinrich Institoris und Jacob Sprenger stammende 'Hexenhammer'." Ibid. 
power struggle which was conducted at this time between local ecclesiastical authorities and the papacy over the issue of episcopal succession would almost certainly have deprived the papally endorsed inquisitor of the degree of regional political support he would have needed to conduct trials of the scale he claims. $^{72}$ Even though there were periods of comparatively intense witch prosecutions - evidence of a concern with maleficium in the diocese date back at least as far $1432^{73}$ - the great majority of those accused came from within either the town or the municipal "Landstrich". 74 This consideration, coupled with the fact that all clerics wishing to press charges of maleficium had to work

72 "Einen größeren Einfluß [as a factor of resistance against Institoris] wird aber wohl der von 1474 bis 1480 dauernde Bistumsstreit gespielt haben. Laut päpstlicher provision war der zum Koadjutor bestimmte Ludwig von Freiberg für die Nachfolge Bischof Hermanns von Konstanz vorgesehen. Bevor aber die Provisionsbullen des Papstes in Konstanz eintrafen, war Bischof Hermann gestorben, und das Domkapitel trat $1474 \mathrm{zu}$ einer Neuwahl zusammen. [...] die Mehrheit [...] wählte Otto Graf von Sonnnenberg zum Bischof. [...] Die Konstanzer obrigkeit wird aufgrund ihrer papstfeindlichen Haltung auch Institoris, der sich als Gesandter des Papstes verstand, die Mission als Hexenjäger in der stadt verwehrt haben. Damit erklärt sich auch, warum die Diözesanmetropole im Hexenhammer keine Erwähnung findet." Ibid., p. 25.

73 Ibid., p. 17. Episcopal promulgations urging both the local clerical and the lay population to proceed against suspected heretics throughout the diocese and especially in the Black Forest region had been issued in 1440 and again in 1442. Ibid., p. 20.

74 Ibid., p. 22. When one considers the extensive region over which the town exerted political control, the possibility that there could have been massive witch trials within the diocese outside of the judicial sphere of the communal authorities appears even more unlikely. "Das Gebiet, auf dem der stadt Konstanz die Blutgerichtsbarkeit unterstand, stieß bald nach den stadttoren auf das Gebiet der Obervogtei Reichenau, die 1548 endgültig in das Hochstift Konstanz inkorporiert wurde. Weitere orte des Bodanrücks unterstanden dem nellenburgischen Landgericht." Zimmermann, "Teufelsglaube und Hexenverfolgungen in Konstanz 1546-1548", p. 32. 
through the secular town council ${ }^{75}$, make it unlikely that a hunt of the proportions which Institoris describes ${ }^{76}$ could have taken place without being recorded in any of the town records. ${ }^{77}$ Although inquisitorial techniques had been introduced into the diocese by the latter part of the fifteenth century, the severity of punishment was largely subject to whim, women almost without exception receiving substantially more lenient treatment. ${ }^{78}$ From 1452 to 1458 there were seventeen executions for a variety of of fenses, but only three victims were women; similarly, from 1473 to 1476 there were sixteen executions but only one woman was involved. ${ }^{79}$ These figures argue against the notion of either uniform or massive burnings of women accused of witchcraft. Apart

75 "Aus den Mandaten geht hervor, daß es dem Klerus in der Diözese an Machtmittel [sic] fehlte, Strafsachen angemessen zu verfolgen. Dies mußte der örtlichen Gewalt überlassen werden. Wennn die letzere nicht mitzog, so konnte die Verhandlung über strafsachen [...] über Jahre verschleppt werden." von Laer, "Die spätmittelalterlichen Hexenprozesse in Konstanz und Umgebung", p. 20.

76 Institoris' credibility as a source is not enhanced by his claim in his letter to the Nürnberg town council of 1491 that more than 200 witches had been detected and executed throughout Upper Germany following the implementations of his methods of inquisitorial jurisprudence. Cf. Endres, "Heinrich Institoris, sein Hexenhammer und der Nürnberger Rat", p. 207.

77 It is significant that the copies of the Urfehden of the Ravensburg witch trials - which, as we know with certainty, Institoris did conduct - are located within the town holdings. von Laer, "Die spätmittelalterlichen Hexenprozess in Konstanz und Umgebung", p. 17.

78 "Nicht jeder Verbrecher, der ein todeswürdiges Delikt beging, wurde auch wirklich hingerichtet. Manch einen kostete eine straftat den Kopf, wogegen ein anderer dieselbe Tat mit seinem Ausgang aus der Stadt abbüßen konnte. Die Rechtswillkür wird ebenso deutlich sichtbar in der Strafmilderung bei Frauen. [...] Die Konstanzer Rechtsprechung behandelte todeswürdige Frauen fast ausnahmslos mit mehr Nachsicht." Ibid., p. 23 .

79 Ibid., p. 23. 
from the Urfehden from the proceedings initiated at Ravensburg in autumn $1484^{80}$, von Laer has been able to uncover only two reported trials for maleficium taking place within the town of Constance itself at the relevant time - that of Anna Iselin ${ }^{81}$ and of Ursel Hanerin ${ }^{82}$, both in 1483 . Even though there is evidence of a growing tendency to associate maleficium with diabolism within the diocese from the 1480 s onwards 83 , there appears little else attesting to the impact of Institoris' inquisitorial zeal within the region.

Other intriguing facets of the passage of II, Q.1, c.4 likewise deserve comment. One of them is the reference to the executions at Bormio.

80 See below.

81 Anna Iselin was released after signing an Urfehde. The relevant entry into the council book of Constance reads "'Ich anna Iselin ... hät ain urfech geschworen von unholden wegen vor dem prennig". Mit dem zuletzt genannten war der damalige Advokat und bischöfliche Kanzler Martin Prenninger gemeint." Ibid., p. 17.

82 Hanerin was put to death apparently on the ground that she had become an unhold after subjecting herself to the devil. The entry in the Ratsbuch reports "'Item illa die ist Ursul Hanerin erkennt zu verbrennen um das sich dem Tuffel ergeben hat und ain hunhold worden ist". Ibid., p. 20. Von Laer also cites the trial and execution of an accused zauberer in the Thurgau region in 1458 which involved one "Cunrat Schatz", presumably the same town councillor cited by Ulrich Molitor in his De Pythonicis Mulieribus, p. 18, as an authority on witch hunting in Constance. Cf. also Hansen, Quellen, pp. 570-1. Although Molitor's work would appear to be an ideal source of evidence of Institoris' activities in the diocese of Constance, it never once mentions the inquisitor. There are only two explicit references to the presence of witchcraft in the region - once on p. 20, "nunc atteri oculus erutus, quodque maledictae mulieres quandoque comprehensae, asserverunt, im torturaque recogneverunt, ab invidiam parentum se talia pueris auxilio Daemonis irrogasse", and on p. 22, "Nam et ego Ulricus ad decem et octo annos in curia Constantiensi causarum Patronus et Advocatus, prout hodie sum, etiam huiusmodi causus frigiditatis et maleficij in practica plures habui, ubi mulieres accusabant coram Iudice maritos de impotentia coëundi."

83 Von Laer, "Die spätmittelalterlichen Hexenprozesse in Konstanz und Umgebung", p. 21 . 
Altogether, there are three other references provided by the Malleus concerning the mass burnings of Bormio under the auspices of the anonymous "Inquisitor Cumanus". The first is in I, Q.11, p. 68 [Schmidt, I, p. 158] when discussing the infanticidal cannibalism practised at sabbats.

Est Inquisitor Cumanus, de quo supra mention habita est ${ }^{84}$, qui haec nobis retuli, quod ea de causa ab inoculis Comitatus Burbiae vocatus ad inquisitionem faciendam, eo videlicet, quod quidam cum puerum ex cuni amisisset, et explorando conventionem mulierum nocturno tempore vidisset et perpendisset infantem occidi, et liquore ebibito devorare. Ideo, ut prius tactum est, unico anno, qui et fuit annus proxime elapsus quadraginta et unam Maleficam igni tradidit, certis aliies ad Dominum Archiducem Austriae Sigismundum fugam capientibus.

The second is in II, Q.1, c.2, p. 105 [Schmidt, II, pp. 28-9] when Kramer enthusiastically proclaims that forty-one witches had been burned within Lombardy.

Nunc autem inconfinibus Lombardiae, versus dominium ducis Austriae: ubi et inquisitor Cumanus, ut in praecedente parte tactum est, uno anno quadraginta et unam Maleficam incinerari fecit, et fuit anno domini 1485, qui etiam adhuc continue inquirendo laborat.

The final entry is in III, Q.15, p. 248 [Schmidt, III, pp. 96-7] when Kramer discusses the question whether witches shoud be shaved of all body hair when being examined by magistrates.

Unde et Cumanus Inquisitor nobis insinuavit, quod anno elapso qui fuit 1485. unum \& quadraginta maleficas incinerari mandasset omnibus per totum corpus abrasis. Et hoc in districtu et comitatu Burbiae, vulgariter dicitur Mormbserbad in confinibus Archiducis Austriae, versus

84 It is puzzling that Kramer should declare this as it is the first time that any reference to the inquisitor of Como is given in the text. 
Mediolanum.

I believe that these passages help provide the key to understanding the ambivalent meaning of the passage taken from II, Q.1, c.4 which is, in fact, that Kramer does not claim to have personally condemned a total of forty-eight witches in the diocese of Constance within a period of five years, but that a sum total of forty-eight had been burned altogether; forty-one of these had been executed in nearby Bormio by the inquisitor of Como, executions which Institoris openly declares that he is going to refrain from discussing in Part Two. This interpretation, of course, implies that Kramer's actual rate of convictions may have been drastically lower than historians have traditionally assumed. 85 Matters might be clarified somewhat by a critical examination of the proceedings at Bormio.

Como was indeed the center of apparently extremely intense witch persecutions during the second half of the fifteenth century. I have been able to ascertain that the anonymous "Inquisitor Cumanus" is, in fact, one Laurence of S. Agatha ${ }^{86}$, who was of ficially appointed inquisitor for Upper Lombardy

85 A typical example is H.C. Lea, who states that "in the little town of Ravensburg alone they boast that they burned forty-eight in five years". Lea, A History of the Inquisition in the Middle Ages, I, p. 540. Cf. also Hafner, Geschichte der Stadt Ravensburq, pp. 41415; Midelfort, Witch Hunting in Southwestern Germany: 1562-1684, p. 201; Müller, "Heinrich Institoris, der Verfasser des Hexenhammers", pp. 397-8. In every instance the respective author cites the Malleus, II, Q.1, C. 4 as his sole source of information.

86 Lea confuses this inquisitor with Girolami Visconti, author of the Lamiarum sive striarum opusculum, failing to take into account the basic fact that this text was composed and published around 1460, a 
on 10 January 1483 by vicar-general Salvus Cassetta and remained active in that region until at least June $1498 .^{87}$ Although it is doubtful that such a sparsely populated region could have sustained such a massive hunt at so early a stage in the history of the persecutions -the only contemporary trials of comparable severity were those at Metz in 1481 when nine women were executed for weather magic ${ }^{88}$ and again in 1488 when twenty-nine men and women were burned $^{89}$, and those at Trier from 1492 to 1494 , during which about thirty women were executed on charges of diabolism 90 , both areas of dense population - it is evident that Como was the focus of long-standing inquisitorial concern. From 1460 to 1470 , a series of ecclesiastical prosecutions of witches in Lombardy and Piedmont, centered on Milan, Turin, and Como, sparked the production of a series of demonological texts and inquisitorial manuals 91

full twenty-five years before the purported events described in the Malleus. Lea, History of the Inquisition in the Middle Ages, $I, p$. 540; Hansen, Quellen, pp. 200, 502; See below.

87 Hansen, Quellen, p. 502.

88 Hansen, Quellen, p. 581; Kieckhefer, European Witch Trials, p. 140; Lea, Materials Toward a History of Witchcraft, I, p. 254.

89 Hansen, Quellen, pp. 586; Hansen, Zauberwahn, p. 507; Kieckhefer, European Witch Trials, p. 143; Lea, Materials Toward a History of Witcheraft, I, p. 256.

90 Hansen, Quellen, pp. 592-4; Hansen, Zauberwahn, p. 508; Grotefend, "Hexen in Frankfurt", p. 73; Kieckhefer, European Witch Trials, p. 145; Lea, Materials Toward a History of Witchcraft, I, p. 257 .

$91 \mathrm{Cf}$. the important qualifier provided by Kieckhefer regarding the value of these texts as historical evidence: "While the treatises do imply familiarity with recent proceedings, any speculation of time and place remains speculative." Kieckhefer, European Witch Trials, p. 
concerning malefic activity and the reality of diabolic flight. In 1490, the first edition of the Lamiarum sive striarum opusculum by Girolamo Visconti (Hieronymus Vicecomes), provincial of the Dominican province of Greater Lombardy from 1465 to c.1477, was published in Milan, detailing the author's purported extensive association with witchcraft in the greater Lombard region. ${ }^{92}$ Visconti's theological speculations were corraborated by more concrete inquisitorial practice, for from 1505 to 1525 , the diocese of Como was subjected to a series of intense ecclesiastical investigations, resulting in an apparently high rate of convictions for demonic malefice. ${ }^{93}$ In 1505 Dominican inquisitorial activity provoked a strongly critical response from Samuel de Cassini, a graduate of the Theology Faculty of Paris and a brother of the Franciscan monastery of S.Angeli in Milan, noted for his highly polemical assaults upon occultist beliefs, especially the writings of Savonarola and the treatises of the Dominican Jakob of Viterbo concerning the immortality of the soul. Combining his nominalist theological training in the via moderna with his order's traditional enmity against the "Hounds of God", a configuration of philosophical and political concerns evidenced time and again throughout the

134.

92 Hansen, Quellen, pp. 200-1; Visconti, Lamiarum sive striarum opusculum, passim.

93 Hansen, Quellen, p. 510. 
history of the witchcraft persecutions ${ }^{94}$, de Cassini published his Question de la strie (or Questio lamiarum), the first explicit objection to the scholastic doctrine of the reality of demonic flight, though itself composed in the form of a scholastic treatise. ${ }^{95}$ The challenge of the Franciscan was met with equal violence by a Dominican, Vincenzo Dodo, regent of the Dominican priory at Pavia, who published his Apologia in 1506, implicitly defending inquisitorial political action by proclaiming the reality of demonic transport denied by de Cassini and reiterating traditional scholastic doctrine concerning incubi and succubi. ${ }^{96}$ Dodo's rejoinder was supplemented in 1508 with the publication of the Tractatus de strigiis of Bernard of Como, inquisitor of the diocese from 21 May 1505 , a treatise that proved so influential as to result in its incorporation into most publications of the composite editions of the Malleus following the 1588 Frankfurt printing. A throughgoing defence of Dominican prosecutions in the face of the threat of the secta strigiarum, which Como declares to be an offshoot of the sabbat-attending Cathars of the Vaudois region accidentally

94 For a discussion of the ways in which nominalist theology could lead directly to scepticism concerning the reality of maleficium, cf. Henningsen, The Witches' Advocate: Witchcraft and the Spanish Inquisition (1609-1614, passim; Obermann, Masters of the Reformation, ch. 9 .

95 Hansen, Quellen, pp. 262-3; de Cassini, Question de la strie, reprinted in Hansen, Quellen, pp. 263-73.

96 Reprinted in Hansen, Quellen, pp. 273-4. 
uncovered by the inquisition in its search for Waldensians 97 , the author even goes so far as to direct the readers' attention to the documentary evidence supposedly contained within the ecclesiastical archive - "qui sunt in archivis inquisitionis nostrae Comensis"98. Despite this onslaught of theological polemicism, considerable opposition remained. Around 1515 the Milanese lawyer Andreas Alciatus issued an official assessment concerning the reality of witchcraft, touching upon the Dominican judicial activity against witches in the Alpine region. ${ }^{99}$ In 1520, Silvester Prierias, Dominican inquisitor for Upper Italy whose sphere included the diocese of Brixen, composed his De strigimagorum demonumque mirandis libri tres (published in Rome in the following year), a formidable work, structurally and argumentatively identical to the Malleus, a text which he cites approvingly on several occasions. 100 Divided into three separate books, the first two are devoted to theoretical concerns, while the third outlines the general set of procedures intended to regulate the actual conduct of witch trials. ${ }^{101}$ So impressive was this achievement that it inspired Prierias' student Bartholomus de Spina to compose,

97 Hansen, Quellen, p. 411. Cf. Bernard of Como, Tractatus de Strigiis, reprinted in Hansen, Quellen, pp. 279-84.

98 Ibid., pp. 279-80.

99 Reprinted in Hansen, Quellen, pp. 310-12. $127-38$

100 Prierias, De strigimagorum, I, C.1, pp. 1-2; II, c.1, pp.

101 Ibid., passim. 
in 1523 , his own treatise, the Quaestio de strigibus et lamiis, a text which presents the orthodox scholastic view of witchcraft in its as yet most developed form while fulfilling its self-appointed task of removing all sceptical doubt that remained concerning the reality of maleficium following the publication of the Malleus Maleficarum, a work which it refers to in three separate chapters. ${ }^{102}$ The Quaestio de strigibus is one of the few texts which provides some allegedly concrete evidence concerning the actual persecution of witches at Como: incredibly, de Spina contests that in Como one inquisitor and between eight to ten assistants annually accuse as many as one thousand women of witchcraft before the secular magistrates and succeed in securing the condemnations of at least one hundred.

Talem autem tantamque esse multitudinem eorum, qui ista fateantur fiére corporaliter, iam universo orbi esse potest exploratissimum ex multitudine eorum, qui propte hec sub iudicio inquisitorum per omnem Christianorum regionem cudunt, ita ut millenarium saepe numerum excedat multitudo talium, qui unius anni decursu in solo Comensi diocesi ab inquisitore, qui pro tempore est, eiusque vicariis, qui octo vel decem aut plures semper sunt, inquiruntur aut examinantur, et annis paene singulis plus quam centum incinerantur. 103

102 De Spina, Quaestio de strigibus et lamiis, c.11, "Potes autem, sivis, in Malleo maleficarum videre, quem observant aliquae Maleficae modum ad id quod diximus assequendum" p. 513; c.17, p. 542; c.19, "Quod si etiam quondoque in somnis haec appareant, vel contingant opere daemonis, non hoc eos latet, ut plurimum qui talia patiuntur, sicut et supradictum est, ex his, quae traduntur in Mallei maleficarum", p. 354.

103 Ibid., c.13, p. 520; cf. also c.33, p. 617 - "Multitudinem quippe magnam puerorum hac pestemori, et si non omnibus notum sit: in his tamen partibus, ubi foetidissima, nec minus credulissima secta haec invalescit, sicut praecipue repereitur in Cumana Dioecesi, et per omnes confines inter Italiam et Germaniam, manifesta docet experimentia, ita ut turmatim populi coguntur Inquisitores accire, requirere, ad proprias 
Although obvious hyperbole, it nevertheless attests to the fact that Como was widely perceived to be a hotbed of witchcraft, an assumption which adds to the plausibility of my reading of the excerpted passage from II, Q.1, c.4 of the Malleus. For if Como was believed to be infested with malefactors, and Institoris (whose extreme gullibility in all matters pertaining to maleficium is well attested) derived his knowledge of the alleged burnings at Bormio from the (supposedly) personal testimony of Laurence of S.Agatha himself, then it appears more than likely that he intended his reference to the "not less than forty-eight burned" to be understood as including the forty-one executed at Bormio, which is not an implausible sum given the high level of presumed diabolic subversion there. If my reading is correct then Kramer was responsible for far fewer deaths than has hitherto been assumed, implying a general failure in securing convictions as is indirectly attested to by his numerous appeals to the papal curia for aid and legal recognition.

A close examination of the remaining contents of the Second Part strongly supports this view, for the text itself provides implicit and indirect evidence for Kramer's unsuccessful, or at least extremely modest, efforts in condemning suspected witches. Out of a gross total of one hundred and seven accounts of maleficium discussed in Part Two, only a meagre eleven explicitly indicate some

terras ducere: ubi vicini atque cognatus, fratres sorores, filij matres, viri uxores, et converso viros quocunque naturali vel accidentali foedere coniunctos, et alias omnes accusant et tradunt in manus Inquisitorum, quas habent personas suspectas quod striges sint." 
sort of judicial process taking place. Admittedly, some of these accounts are highly ambiguous - in II, Q.5, c.5, p. 125 [Schmidt, II, pp. 73-4], the text's infamous Host-miracle story, the witch of the unnamed town ${ }^{104}$ is arrested, but no mention of her trial (if any) or her sentence is provided. Of the more explicit cases, several are clearly not pertinent to the matter at hand, ascertaining Kramer's whereabouts and activities during his inquisitorial career. At least two references - the arrest and execution of the Zauberer Staldin (Stadlin, Staedlin) ${ }^{105}$ as well as the execution in Bern of the repentant husband and the unrepentant wife $\mathrm{e}^{106}$ are both taken directly from the Formicarius. ${ }^{107}$ The confession, arrest, interrogation, and execution of the

104 "Oppidium quod nominare non expedit, quia ordo charitatis et rationis imperat et saudet." I have tentatively identified this town as Entlibuch in the diocese of Lucerne, proof that at least some of the anecdotes supplied in the Malleus were taken second-hand from territories outside of Kramer's sphere of jurisdiction, more often than not from the witch-infested dioceses of Switzerland which did not fall under Institoris' direct authority but which lay in immediate proximity to his own area of operations. So far I have not been able to specify the time of the purported incident. Hoffman-Krayer, "Luzerner Akten zum Hexen- und Zauberwesen", p. 87. This article is an extensive compilation and transcription of all recorded witch trials held at the Staatsarchiv in Lucerne from the years 1463 to 1551 . In Hansen, Quellen, pp. 582-3, there is a trial of a suspected witch on 20 May 1482 in Lucerne, but I cannot ascertain from this account whether it is the same woman.

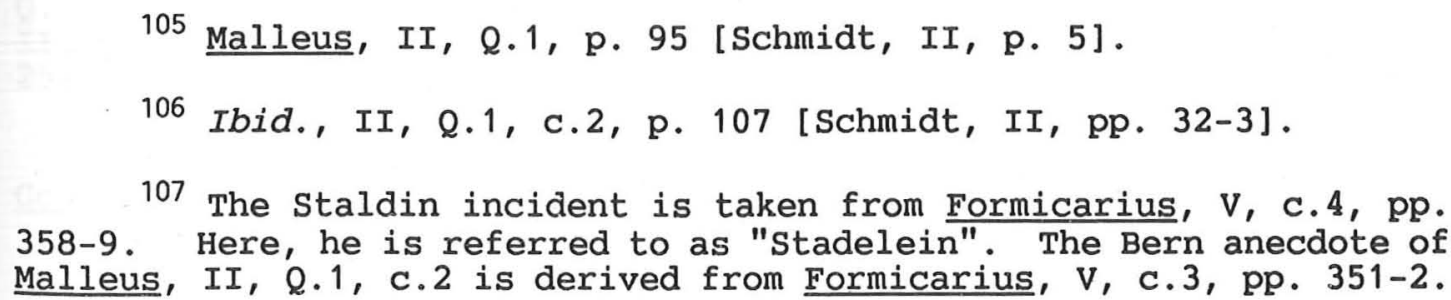

107 The Staldin incident is taken from Formicarius, V, c.4, pp. 358-9. Here, he is referred to as "Stadelein". The Bern anecdote of Malleus, II, Q.1, C.2 is derived from Formicarius, V, c.3, pp. 351-2. 
"archer-wizard" (malefici sagittaris) ${ }^{108}$ after his causing a roadside cross to bleed through piercing it with satanic arrows is obviously set well in the past. $^{109}$ The death of the suspected witch in Hagenau, apparently in the year $1483^{110}$ is obviously a suicide, most likely the result of Kramer's tortuous interrogation rather than the product of a formal condemnation, as the first recorded witch trial at Hagenau appears to have taken place in 1531. ${ }^{11}$ The arrest and confession of an anonymous cunning man for having inflicted his neighbour's house with barrenness ${ }^{112}$ is too vague with regard to time and place to be practically useful; that one should not automatically assume that a sentence resulted from a confession of guilt is clearly evidenced by the text's

108 Rothkrug, "Icon and Ideology in Religion and Rebellion: 13001600", pp. 43-4. Rothkrug advances the weak argument that the figure of the "archer-wizard" was the result of the ecclesiastical authorities' attempts to diabolize south German proponents of Swiss republicanism.

109 Malleus, II, Q.1, c. 16, p. 164 [Schmidt, II, p. 164]. Karl Müller identifies the anonymous nunnery of the anecdote as stettin near Hechingen, Stetten im Gnadental. According to him, the archer-wizard shot an arrow into the portrait of the Redeemer set in a Kreuzweg and it was the illustration that dripped blood, the church being built around the Kreuzweg as a commemoration. Müller, "Heinrich Institoris, der Verfasser des Hexenhammers", p. 416.

110 Malleus, II, Q.1, c.2, p. 109 [Schmidt, II, p. 37]. The text cites the death as occuring "acta sunt, vix annis tribus evolutis", only one of a total of seven specific references to time in the Malleus. The others are in I, Q.11, p. 68 [Schmidt, I, p. 158]; II, Q.1, c.4, p. 119 [Schmidt, II, p. 61] ; II, Q.1, c.6, p. 126 [Schmidt, II, p. 77]; III, Q.15, p. 251 [Schmidt, III, p. 96]; III, Q.17, p. 254 [Schmidt, III, p. 110].

111 Klele, Hexenwahn und Hexenprozesse, p. 33; Riezler, Geschichte der Hexenprozesse in Bayern, pp. 97-100.

112 Malleus, II, Q.1, c.6, p. 126 [Schmidt, II, p. 76]. 
lamentation of the current freedom of two publicly confessed witches. ${ }^{113}$ Equally - and disappointingly - vague is the account provided by an unnamed man of an unspecified region who at one time in the past had delivered his wife and daughter over to the hands of the local judge to be executed for demonic midwifery. ${ }^{114}$ The fact that the text indicates that this story was related to Kramer by someone else is not in itself remarkable as the Malleus contains at least five other references in addition to the trials at Bormio which are conveyed to the author second-hand. ${ }^{115}$ Hence, even if the information provided in the account is accurate, it is quite possible for the event itself to have occured sometime well before Kramer's career as an inquisitor of heretical depravity had officially commenced; in any event, there does not seem to be any account of any trial from the years 1481 to 1486 that even remotely resembles

113 Ibid., I, Q.7, pp. 126-7 [Schmidt, I, pp. 117-18]; II, Q.1, c. 1, p. 102 [Schmidt, II, pp. 20-1]. The text refers to the second witch as "seculari brachio defensa". This suggestive reference to secular law impinging upon the proper execution of inquisitorial justice is perhaps indicative of the extent of the opposition encountered by Kramer.

114 Ibid., II, Q.1, c.13, p. 156 [Schmidt, II, pp. 138-40].

115 Ibid., I, Q.15, p. 82 [Schmidt, I, p. 190] - "ubi inter nos inquisitores unius reperit"; I, Q.18, p. 92 [Schmidt, I, p. 214] "Res gesta uni ex nobis innotuit"; II, Q.1, c.3, p. 112 [Schmidt, II, p. 44] - "Et licet duo simus hunc tractatum scribentes unus tamen ex nostris saepissime tales vidit et reperit"; II, Q.1, c.3, p. 115 [Schmidt, II, p. 52] - "qui pro tunc consodalis illius existens"; II, Q.1 c.12, p. 148 [Schmidt, II, p. 148] - "Tamen ex his, quae oculis nostris perspeximus, et quae uni ex Inquisitoribus innotuerunt, aliqua in medium producamus"; II, Q.2, p. 174 [Schmidt, II, p. 190] - "In civitate Spirensi mercator quidam forensis hunc casum sibi accidisse proposuit." 
the account. 116 An anonymous witch, the aunt of a young servant girl in the town of Breisach in the diocese of Basel who was herself suspected of witchcraft, was allegedly burned in Straßburg, but apparently sometime well before the account was related to Institoris - furthermore, it is not clear whether the suspect niece was executed. ${ }^{117}$ Equally ambivalent is the fate of the confessed homicidal midwife of Straßburg. ${ }^{118}$ The text's repeated references to the trial and execution of Anna of Mindelheym and Agnes Baderin of Ravensburg, the only two executed witches cited by name in the whole of the Malleus $^{119}$, its lamentation over the authors' failure to condemn two

116 Hansen, Quellen, pp. 581-6; Kieckhefer, European Witch Trials, pp. 140-3.

117 "Hunc modum nos inquisitores (experientia teste) percepimus in oppido Brisaco Basiliensos dioecesis, plenam informationem capiendo $\mathrm{ab}$ una iuuenccula malefica, sed conversa cuius et matertera in dioecesi Argentinensi [...]." Malleus, II, Q.1, c.2, p. 106 [Schmidt, II, pp. 29-30]. This girl provides Kramer with a plethora of information concerning malefic activity, including an account of an event that appears to be the Sabbat in II, Q.1, c.2, p. 106 [Schmidt, II, pp. 2930 ] as well as considerable details concerning the nature of demonic transport - Malleus, I, Q.16, p. 86 [Schmidt, I, p. 200]; II, Q.1, c.2, p. 106 [Schmidt, II, p. 33]; II, Q.1, c.3, p. 115 [Schmidt, II, p. 52] - used by Kramer in refuting the pronouncement of the Canon Episcopi upon the question of the illusory nature of nocturnal flight as well as the diabolic activities of midwives. Ibid., II, Q.1, C.13, p. 152 [Schmidt, II, pp. 137-8]. It is unclear whether this girl is identical with the leprosy-inducing witch mentioned in II, $Q .1, \mathrm{C} .11$, p. 148 [Schmidt, II, p. 126]. See below, Chapter Seven.

118 "Insuper (ut in prima parte operis) ex illius famulae reductae ad praesentiam in Brisiaco confessione patiut, maiora damna fidei circa hanc haeresim maleficarum ab obstetricibus inferri, quod etiam quarundam confessio, quae postmodum incineratae fuerunt, luce clarius demonstravit." Ibid., II, Q.1, c.13, p. 152 [Schmidt, II, p. 137].

119 Ibid., II, Q.1, p. 96 [Schmidt, II, p. 5]; II, Q.1, c.1, p. 102 [Schmidt, II, p. 21]; II, Q.1, c.2, p. 109 [Schmidt, II, p. 37]; II, Q.1, c. 4, pp. 119, 122 [Schmidt, II, pp. 60, 78]; II, Q.1, c.14, pp. 158-9 [Schmidt, II, p. 152]; II, Q.1, c.15, pp. 161-2 [Schmidt, II, p. 157]. The other two witches named, "Vvaltpurgis" of Ravensburg 
confessed witches ${ }^{120}$, and its open criticism of Count Heinrich of Fürstenburgs's recourse to trial by ordeal when judging a case, resulting in an accused witch escaping punishment ${ }^{121}$, coupled with Kramer's spectacular lack of success in prosecuting witches in the Tirol ${ }^{122}$ all strongly recommend the prudent course of holding no witch referred to in the Malleus to have actually been burned by Institoris unless clearly specified as such in the text.

This criterion can be applied to only seven cases in the whole of the Second Part of the Malleus: a witch burned at Buchel in the diocese of Basel after confessing to having slept with an incubus over a period of five years 123 ; a witch burned at Waldshut in the diocese of Constance for having

and another "Vvalburgis" at Innsbruck - II, Q.1, c.2, p. 109 [Schmidt, II, p. 37]; II, Q.1, c.12, p. 151 [Schmidt, II, p. 134] - do not appear to have been put to death. See below.

120 Ibid., I, Q.7, pp. 50-1 [Schmidt, I, pp. 117-18]; II, Q.1, c. 1, p. 102 [Schmidt, II, pp. 20-1].

121 Ibid., III, Q.17, p. 254 [Schmidt, III, p. 110]. See also Hansen, Quellen, p. 584; Hansen, Zauberwahn, p. 431; Lea, Materials Toward a History of Witchcraft, I, P. 255; Riezler, Fürstenberqisches Urkundenbuch, IV, p. 42; Riezler, Geschichte der Hexenprozesse in Bayern, pp. 78,102. There is a curious error in the text. All of the sources specify that the trial in question took place on 14 March 1485 , yet the Malleus cites the event as occuring three years previously "tribus anni vixiam elapsis contigisse fertur" - which would indicate 1483 or 1484. The most ready explanation is a lapse in Kramer's memory, demonstrating the degree to which the text was compiled on the basis of Institoris' personal and highly subjective recollection.

122 Ibid., II, 0.1, c.12, pp. 148-51 [Schmidt, II, pp. 128-34]. At no point in his account does Institoris explicitly state that any executions actually took place.

123 Ibid., II, Q.1, c.2, pp. 110-11 [Schmidt, II, pp. 40-1]. 
practised weather magic ${ }^{124}$; a leprosy-inducing witch burned somewhere in the area of Alsace and Lorraine within the diocese of Basel ${ }^{125}$; another such witch also burned in the diocese of Basel, this time within the general vicinity of the Black Forest ${ }^{126}$; a diabolic midwife burned in the town of Dann in the diocese of Basel after confessing to have murdered more than fifty infants by inserting a steel pin into their heads ${ }^{127}$; a weather-magic witch, somewhere in Swabia, who was denounced by her husband ${ }^{128}$; and, of course, Anna of Mindelheym and Agnes of Ravensburg, discussed together at length in II, Q.1, c.15, pp. 161-2 [Schmidt, II, pp. 157-60]. The total number of witches that the Malleus explicitly declares to have been arrested, interrogated, tried, confessed, and executed, (presumably) within the approximate time and place comes at the very most to eight. But even some of these cases are suspect in yielding evidence of Kramer's own direct participation. Although it is definitely possible that Institoris could have played a role in the Swabian af fair discussed in II, Q.1, c.13, p. 156 [Schmidt, II, pp. 145-6] it seems just as likely that he could have

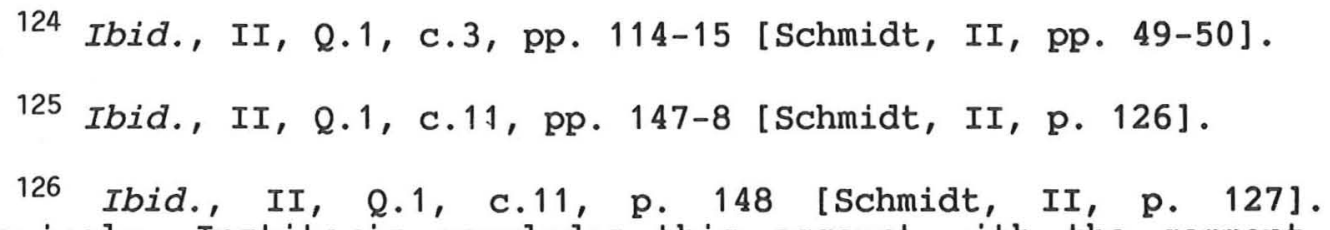
Intriguingly, Institoris concludes this account with the comment, "horrenda eius facinora brevitatis causa obmittuntur: sicut et alia quasi innumera, super haec recitari possent", possibly suggesting a first-hand acquaintance with the case.

Ibid., II, Q.1, c.13, p. 152 [Schmidt, II, p. 137].

128

Ibid., II, Q.1, c.13, p. 156 [Schmidt, II, pp. 145-6]. 
learnt the story second-hand during his time at Ravensburg - the actual account is simply too meagre in details of time and place (other than those occurring in a region that Kramer is known to have been active in) to decide either way prima facie. Additionally, the execution of the murderous midwife of Dann is rendered somewhat suspect by its tremendous brevity: in all, a single sentence, "Nam in diocesi Basiliensi, et oppido Dann, quaedam incinerata fassa fuerat, ultra quodraginta pueros necasse, per modum talem, ut quando ex utero egrediebatur, acum capitibus eorum per verticem usque in cerebrum infigeret", which is a paltry account in comparison not only with the other cited incidents of interrogation and execution, but also with the numerous lengthy anecdotal accounts of witchcraft with which Institoris did not have any direct familiarity and/or which did not result in a formal judicial process of any sort, such as the merchant of Speyer's tale of being crippled by a witch after failing to make the sign of the Cross ${ }^{129}$, or the attack of a labourer by three shape-shifting matrons in the guise of gigantic demonic cats. ${ }^{130}$ However much one could argue about the merit of individual cases as evidence, the total number of witches that the Malleus specifies as having been put to death by Institoris himself falls well within the number seven, derived when subtracting forty-one,

129 Ibid., II, Q.2, pp. 174-5 [Schmidt, II, pp. 190-1].

130 Ibid., II, Q.1, c.9, pp. 136-7 [Schmidt, II, pp. 99-102]. "Est oppidum in diocesi Argentinensi, cuius nomen occultare ordo charitatis et honestatis postulat." 
the number of witches executed at Bormio, from forty-eight, the total number of condemned specified by the text. It thus seems possible to conclude that the figure of forty-eight mentioned in II, Q.1, c.4 refers not to the number of witches tried and executed by Kramer personally, but rather to the grand sum of witches estimated by Institoris to have been burned throughout the general vicinity of the diocese of Constance from the years $1481 / 2$ to $1485 / 6$, including those forty-one allegedly burned in Bormio. If Institoris had, in fact, succeeded in condemning only seven accused women this would go someways towards explaining the paucity of material concerning his witch-hunting activities, something not to be expected if his total number of convictions approached fifty.

This consideration, however, in no way reflects the evidently considerable number of anonymous victims that must have been accused, arrested, interrogated and perhaps even tried by Kramer himself though spared death a not improbable result considering the general reluctance of fifteenth-century German secular courts to condemn heretics or witches to death ${ }^{131}$ - to say nothing of those whose judicial ordeals, of whatever nature, were never recorded. More to the point, such a conclusion is far more consistent with the political and judicial turmoil suffered by Institoris as an inquisitor, clearly $76-79$

131 Kieckhefer, The Repression of Heresy in Medieval Germany. pp. 
evidenced by his extensive negotiations with the papacy for a greater and clearer recognition of his juro-political authority. If Institoris had indeed succeeded in executing forty-eight suspects within a single diocese over the meagre period of five years then he would have possessed considerable grounds for self-congratulation. In fact, all the available evidence supplied by documents like the Summis, especially when seen in connection with the refrain of the Malleus' repeated denunciation of the scepticism and apathy of local ecclesiastical and secular authorities, strongly suggests a beleagứed inquisitor constantly encountering failure and stiff regional opposition - in short, a political climate indicating tremendous reluctance to engage in extensive judicial enquiries into the presence of alleged witches, let alone the actual execution of forty-eight accused women. 132

The only possible objection to this suggestion which can be constructed on the basis of the internal evidence of the Malleus, namely the execution of an unspecified number of heretics at Regensburg ${ }^{133}$, can easily be discounted.

132 of importance when considering the question of numbers are those contemporary witch trials in which Kramer's absence is apparent. None of the records of the trial of the two witches, the Stalkerin and the Ruschellerin, executed at Diersburg in 1486 contain any mention of Kramer's presence. Cf. Eckstein, "Zum Diersburger Hexenprozess vom Jahre 1486", pp. 635-6; Hansen, Quellen, pp. 584-6; Kittredge, Witchcraft in old and New England, p. 163. Furthermore, no account provided in the Malleus corresponds to the depositions of this trial.

133 "Sed quid in Diocesi Ratisbonensi casu contigisse afferitur? Quod dum quidam haeretici ex propria confessione devicti, non solum ut impoenitentes, imo et defensores illius perfidiae, morti fuissent adiudicati, accidit, ut illaesi in igne remanerent: Tandem per aliam sententiam ad submersionem adiudicati, nihil proficere potuerunt: Stuoentibus omnibus, et fidem ipsorum ut iustam defendere dum quidam 
First of all, the text clearly specifies that heretics (haeretici) and not witches (malefici) were burned. Secondly, the reference occurs in Part Three and not in Part Two, the portion of the Malleus designated in II, Q.1, c.4 as the site of the discussion of the relevant witch trials. Thirdly, the exact number of the executed is omitted, as is any mention of the precise time of the executions. It is quite possible, therefore, that the executions could have occured sometime well before 1481 - the interrogation of the weather-magic witch at Schlettstadt, also cited in Part Three, occumed no later than $1478 .^{134}$ Furthermore, on the basis of the exceedingly slim evidence we do possess concerning the trial ${ }^{135}$ it does appear as though neither Kramer nor Sprenger were personally involved in the proceedings. Although it is true that Institoris was involved with inquisitorial inquiries concerning the alleged presence of heretics in the diocese of Regensburg, this took place in the early 1490 s, well after the publication of

conabantur, sollicitus praesul super gregem, triduanum ieiunium indixit, quo devote expleto cuidam notificatur, quod in certo loco corporis, videlicet sub brachio uno, maleficium quoddam inter pellem et carnem insutum haberent, quo reperto et amoto, continuo incendio consumpti fuerunt. Licet ab aliis opinetur, quod quidam Necromanticus ex Daemonis consultatione, qui sibi hoc indicaverat, prodidisset. Sed quocunque modo factum fuerit, verisimile est, quod divina virtute Daemon coactus, dum semper ad subversionem fidei machinatur, hoc manifestaverit." Malleus, III, Q.15, p. 248 [Schmidt, III, pp. 95-6].

134 Ibid., III, Q.16, p. 251 [Schmidt, III, p. 103]; Cf. Kunstmann, Zauberwahn und Hexenprozeß in der Reichststadt Nürnberq, $p$. 23.

135 Hansen, Zauberwahn, p. 424; Riezler, Geschichte der Hexenprozesse in Bayern, p. 63. 
the first edition of the $\underline{\text { Malleus }}^{136}$, and it is far from clear whether any executions actually resulted from the investigations. The very fact that an account of a (supposedly) contemporary burning of heretics was relegated to the middle of the Third Part, warranting only a single mention, itself suggests that the account was added subsequently, perhaps as an afterthought in the course of the composition of the treatise from between 1486 to 1487 .

This sole counter-example notwithstanding, it would appear that the conclusion concerning the smaller number of condemned witches executed could be employed in helping to clarify some of the more striking features of the Malleus, in particular the seemingly disproportionate emphasis laid upon the judicial proceedings at Ravensburg. The various accounts of this trial include the text's only extensive discussion of the inquisitorial procedures and torture techniques actually employed in the interrogation of witches ${ }^{137}$, detailed summaries of the malefic transgressions of the accused ${ }^{138}$, the only explicit citation of the names and activities of the local authorities assisting Institoris ${ }^{139}$, as well as a rather lengthy account of Kramer's own personal

136 See above, Chapter Two.

137 see below.

138 Ibid., II, Q.1, c.14, pp. 158-9 [Schmidt, II, pp. 151-2]; II, Q.1, c.15, pp. 161-2 [Schmidt, II, pp. 158-9].

139 Ibid., II, Q.1, c.15, p. 161 [Schmidt, II, p. 158]. A "zealous" magistrate named Gelre is cited. See below. 
experiences during the trial, when he claims that he suffered malefic assault. $^{140}$ If Institoris had indeed tried and executed the forty-eight witches that are normally attributed to him, then the two burnings at Ravensburg would not seem to merit such attention - a total of nine separate references in all. If, on the other hand, only a maximum of seven or eight had been burned by the inquisitor then the cases of Anna of Mindelheym and Agnes Baderin assume much greater significance, representing a substantial part of the total sum of suspects condemned by the inquisitor. This would also, of course, explain the text's citation of Ravensburg as a site of exceptionally acute malefic activity and extensive judicial proceedings. ${ }^{141}$ In supremely ironical fashion, it was not Kramer's great success but rather his repeated failures in obtaining the executions of large numbers of witches, that prompted him to undertake such desparate measures as his repeated petitioning for judicial recognition from an obviously indifferent papacy, the forgery of the letter of approbation from the Cologne theology faculty, as well as the composition of

140 "In oppido nempe Ravenspurg. dum a consulibus maleficae incinerande interrogarentur, cur nobis inquisitoribus aliqua maleficia, sicut aliis hominibus non intulissent. Responderunt: Licet pluries hoc facere attentassent, non tamen potuerunt. Et de causa inquirentibus respondebant se nescire, nisi quod a Demonibus informatae, enarrare non sufficimus, iam ut simiae, cum iam ut canes, aut caprae suis clamoribus et insultibus nos inquietarent de nocte, ad orationes, licet indevotas, surgentibus, extra fenestram loci, quae tamen in tanta altitudine erat, guod nisi per longissimas scalas quis adire potuisset: ictu validissimo quasi ad caput de directo percutiebat, acus linteo, quo caput nostro immittere voluissent. Sed laus altissimo, qui sua pietate, absque meritis nostris, nos tanquam publicos iustitiae fidei indignos famulos praeservavit." Ibid., II, "Introductio", p. 95 [Schmidt, II, pp. 5-6].

141 Ibid., II, Q.1, c.4, p. 119 [Schmidt, II, p. 60]. 
the Malleus itself - in short, an atmosphere of intense political hostility and instability, as a close examination of the extant judicial records of the trials at Ravensburg and Innsbruck clearly reveal.

\section{2. Ravensburg and Innsbruck.}

Kramer's discussion of the trials at both Ravensburg and Innsbruck are unique in that they are the only two trials mentioned in the whole of the text in which it is clearly indicated that written records of the proceedings exist. An allusion to extant trial records held at Ravensburg is made in II, Q.1, c.15, p. 162 [Schmidt, II, p. 160] - "uti processus ad consulatum repositus demonstrat" - while a similar such reference is provided with regards to Innsbruck in II, Q.1, c.1, pp. 103-4 [Schmidt, II, p. 24] - "Si ea quae in uno dumtaxat oppido illius diocesis reperta sunt, inferenda essent, liber integer foret conficiendus, conscripta autem et reposita sunt apud eundem Episcopum Brixen et utique stupenda et inaudita, ut testis idem existit."

The holdings at Ravensburg are a fortunate occunence, given the apparent lack of extensive of ficial records of any witch trial in Oberschwaben prior to 
$1500 .^{142}$ In addition to the text's own account of the events ${ }^{143}$ one of the few pieces of information that remains is a copy of a letter in the vernacular, dated 17 December 1484, from the anonymous mayor of Ravensburg $^{144}$ to Archduke Sigismund of Austria who had, by that time, taken up permanent residence in the immediate vicinity of nearby Innsbruck. ${ }^{145}$ This letter was itself a response to a previous missive no longer existant, sent by Sigismund inquiring into the inquisitorial prosecution of witches that had taken place in the community the previous autumn. ${ }^{146}$

In addition to this letter, the only other major evidence concerning the Ravensburg witch trial is the archive's collection of Urfehden listed for the

142 Müller, "Heinrich Institoris, der Verfasser des Hexenhammers und seine Tätigkeit als Hexeninquisitor in Ravensburg im Herbst 1484", p. 397. Müller was chief archivist at the Stadtarchiv Ravensburg and his article is widely accepted as the authoritative work on Kramer's activities in the area. Through my own correspondence with the current director, Dr. E. Eitel, I have been able to obtain photocopies of the relevant extant holdings of the archive - U. 1116, 1119, 1129, 1131. These are discussed below. Dr. Eitel was unable to provide me with any information concerning additional sources.

143 Ibid., p. 412; Malleus, II, Q.1, p. 96 [Schmidt, II, p.5]; II, Q.1, c.1, p. 102 [Schmidt, II, p. 21]; II, Q.1, c.2, p. 109 [Schmidt, II, p. 37]; II, Q.1, c.4, p. 119 [Schmidt, II, p. 60]; II, Q.1, c.7, p. 127 [Schmidt, II, p. 78]; II, Q.1, c.14, pp. 158-9 [Schmidt, II, p. 152]; II, Q.1, c.15, pp. 161-2 [Schmidt, II, pp. 15760 ].

144 Konrad Geldrich, member of the patrician Geldrich family of Sigmarshofen, served as Bürgermeister of Ravensburg from 25 July 1484 to July 1485; he is, if not identical, then certainly related to the magistrate "Gelre" cited with so much approval in II, Q.1, c.15, p. 161 [Schmidt, II, p. 158] of the Malleus. Müller, "Heinrich Institoris, der Verfasser des Hexenhammers", p. 410 .

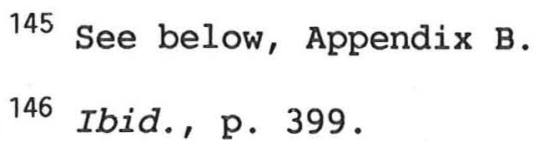


years 1484 to $1490 .{ }^{147}$ The earliest of these Urfehden is dated 23 October 1484, indicating that Institoris could not have arrived in Ravensburg much later than the first week of October. ${ }^{148}$ However, as in every instance the Urfehden were issued at the time of the suspect's release from prison, it does not appear likely that all of the accusations that resulted in imprisonment were actually made during Kramer's period of residence in the town. It seems a more likely conclusion that Kramer's influence on the community, in the form of accusations of witchcraft, far outlasted his actual presence there ${ }^{149}$; the later Urfehden are indicative of the lastingness of Kramer's influence upon the community. In any event, on the basis of the Urfehden ${ }^{150}$ we can conclude that a total of at least six other women, in addition to the condemned Anna and Agnes - Margareta Schumacher of Oelschwang, Margareta Stricklin of Ravensburg, Elisabeth Frauendienst of Ravensburg, Barbara Vischer of Zussdorf, along with two others who are not named - were formally accused of malefic transgression sometime during the second half of the decade. ${ }^{151}$ However,

147 Müller suggests that it was this collection of Urfehden that Institoris was referring to in II, Q.1, c.15 of the Malleus. Ibid., p. 408 .

148 Ibid., p. 408.

149 Hafner, Geschichte der Stadt Ravensburq, p. 408.

150 Stadtarchiv Ravensburg, U. 1116, 1119, 1129.

151 Müller, "Heinrich Institoris, der Verfasser des Hexenhammers", p. 414 
as the actual depositions do not appear to have survived and the Urfehden contain no details of the crimes allegedly perpetrated by any of the accused $^{152}$ any detailed analysis of the witchcraft beliefs and possible practices of the local populace becomes extremely difficult. Several generalizations can be forwarded, however, with a fair measure of certainty. First, because of the gaps in the existing evidence, there is no explicit indication of the accused having committed any action that resembled some form of diabolism. For example, the incident related in II, Q.1, c.7, p. 127 [Schmidt, II, pp. 78-9], involving a young man physically forcing a witch to restore his sexual potency, is obviously an improvised attempt at a rudimentary form of counter-protective love magic. This is even more apparent in the text's accounts of the interrogation and execution of Anna of Mindelheym and Agnes Baderin $^{153}$, who, if guilty of anything, were most likely guilty of practising some sort of weather-magic, an occult capability widely attributed to "cunning

152 Without exception the Urfehden follow typical bureaucratic procedure in focusing upon the repentance and the disavowal of vengeance on the part of the accused; no details of the original accusations of maleficium are reproduced. Stadtarchiv Ravensburg, $U$. $1116,1119,1129,1131$.

153 Müller argues that "Mindelheym" refers to Anna's town of origin rather than her surname. Müller, "Heinrich Institoris, der Verfasser des Hexenhammers", p. 410. He also asserts that "Baderin" was an established family name in Ravensburg from at least the beginning of the fourteenth century and has nothing to do with being a "bath woman" as Summers erroneously implies. Ibid., p.409; Summers, The Malleus Maleficarum, p. 148. 
folk" in southern Germany at this time ${ }^{154}$ - the charges of attempting to win young girls over to satanic heresy or engaging in carnal intercourse with demons $^{155}$ appear to be purely spurious additions.

The second generalization pertains to the ways in which the available documentary evidence subtly points to the decisive role played by Institoris himself and his inquisitorial "art" in formenting the social unrest that led to the execution of at least two of the accused. As with the later witch trial at Innsbruck ${ }^{156}$, there is no indication of any serious concern with satanic maleficia in the Ravensburg area prior to Kramer's arrival. ${ }^{157}$ This is not to imply that any form of malefic Aberglaube was entirely non-existent - the incident recounted in II, Q.1, c.7 clearly demonstrates the reality of widespread fear at the popular level concerning malefic sexual dysfunction. Furthermore, Institoris claims that popular fears aroused by a recent hailstorm propelled him to initiate proceedings, with considerable public support.

Ad ea tamen, quae per nos reperta sunt, expedit discurrere. In dioecesi namque Constantiensi, ab oppido Ravenspurg. viginti octo milliaria Teutonicalia versus Saltzburgam, grando saevissima excitata, cunctus fruges, segetes et vineta adeo in latitudine unius milliaris contriverat, below.

154 Malleus, II, Q.1, c.15, p. 161 [Schmidt, II, p. 157]. See

155 Ibid., II, Q.1, c.1, p. 102 [Schmidt, II, pp. 22-3].

156 see below. The pertinent sources are transcribed in Amman, "Der Innsbrucker Hexenprocess von 1485", passim.

157 Stadtarchiv Ravensburg, U. 1116, 1119, 1129, 1131. 
quod tertius annus vix iudicabatur frugiferus in vinetis. Unde res gesta cum per notarium inquisitionis innotuisset, per maleficia, imo omnes pene opppidanae talia contigisse iudicarent. 158

The text then continues

Quare consulibus ad id consentientibus, per quindenam iuxta iuris formam, super haeresim dumtaxat Maleficarum a nobis inquiritur, non ad duas dumtaxat personas prae aliis, quae tamen in paruo numero non erant, diffamatas pervenitur: nomen unius Angetis Balneatricis: altera Annae de Mindelheym [sic]: quibus captis, et seorsim ad distinctos carce res positis, ignorante penitus una de altera $[. . .]^{159}$

Despite these claims, Kramer's denunciations from the pulpit, coupled with the attendant threat of excommunication for failure to comply, would almost certainly have forcibly compelled members of the lay populace to come forward with any sort of supernatural grievance they may have held against their neighbours. These sermons acquire even greater importance if one recalls that one of Kramer's primary goals was to serve as an exemplar to local populations in the hope of encouraging them to engage in further persecutions after his departure, an objective which he seems to have accomplished at least in

158 Malleus, II, Q.1, c.15, p. 161 [Schmidt, II, p. 157]. This diverges somwehat from the account provided in the letter of the town mayor, which suggests that proceedings were started with Institoris conducting a unilateral investigation. What both accounts indicate, however, is a fairly strong measure of local public support for some sort of anti-witch proceedings - it seems most likely that this grassroot endorsement served as a key to Institoris' comparative success in the community.

159 Ibid. [Schmidt, II, pp. 157-8]. Institoris is rigorously following inquisitorial procedure concerning the segregation of suspects. 
Ravensburg. ${ }^{160}$ Furthermore, as it was Kramer's practice to let the secular authorities handle the actual procedures of the trial and to continue with his work afterwards in his absence, it appears an obvious deduction, on the basis of the contents of the mayor's letter, that Institoris must have provided some sort of instruction in witch hunting to the town authorities. ${ }^{161}$ The resultant accusations initiated from below would, in turn, have been actively reinterpreted by Institoris so as to be rendered constistent with the emergent stereotype of the diabolic witch. This is particularly well evidenced in the text's description of Anna Baderin's confession regarding the creation of a hailstorm in II, Q.1, c.15, pp. 161-2 [Schmidt, II, pp. 158-9].

Quibus expletis, ubi super grandinem praefatam, an ne aliquid de illo sciret, inquireretur? Respondit quod sic. Et interrogata quomodo et qualiter? Respondit, In domo eram et hora meridiei Daemon me accersiuit, et vt super campum seu planitiem Ruppel (sic enim nominatur) paululum aquae mecum derendo, me transferrem iniunxit: et dum interrogassem, quidnam operis in aqua explere vellet, pluniam se velle causare respondit: portam ergo cuitatis exiens, ipsum Daemonem sub arbore stantem reperi. Interrogata autem a Iudice sub qua arbore? Respondit: Sub illa ex opposito illius turris, ipsam denotando. Et interrogata quid sub arbore egisset: respondit. Daemon vt foueam paruzam foderem, et illi aquam infunderem iniunxit. Et interrogata, an ne pariter consedissent? Respondit: Me sedente ipse Daemon stabat.

160 "Nach dem Willen des Inquisitors sollte mit seiner Abreise aus der stadt nicht die Periode der Hexenverfolgungen aufhören, vielmehr sollte sein Aufenthalt in der stadt und die Leitung der Hexenprozesse durch ihn nur dazu dienen, die weltlichen Behörden mit der geeigneten Inangriffnahme solcher Prozesse vertraut $\mathrm{zu}$ machen und sie von der Gefährlichkeit dieser Leute und der Pflicht der Obrigkeit, gegen die Hexen einzuschreiten, überzeugen." Müller, "Heinrich Institoris, der Verfasser des Hexenhammers", p. 407. 
Interrogata demum quibusne verbis aut modis aquam mouisset? respondit digito quidem moui, sed in nomine ipsius Diaboli et omnium aliorum Daemoniorum. Et rursum Iudex, quid actum fuisset de aqua? Respondit: disparuit, et sursum in aëra Diabolus duxit. Et demum, an ne aliquam haberet sociam interrogata: respondit: ex opposito sub tali arbore aliam captam maleficam Annam videlicet Mindelheym nominando, consodalem habui, quid autem egerit ignoro. Et finaliter interrogata balneatrix de interuallo temporis ab aquae assumptione vsque ad grandinem, respondit: Tanta dilatio fuit, quovsque ad domum peruenissem.

The way in which Institoris is able thoroughly to integrate diverse facets of the witch ideology with mundane practices and beliefs is remarkable. Anna Baderin's account of weather magic certainly sounds like a standard popular means of raising hailstorms; yet that practice is rendered diabolic through the postulation of the presence of a demonic agent as a necessary element in the efficacy of the ritual. Furthermore, elements of an organized conspiracy or sect are insinuated through the interrogator's demands for the name of an associate, thus placing Baderin (as well as Mindelheym) within the stereotypical framework of the satanic witch-heretic. These connotations are drawn even more sharply when the text declares that Agnes had long-standing sexual intercourse with a demon, the hallmark of a diabolical heretic. 162

162 "Nam a Notario inquisitionis interrogata super articulos et depositione testium, circa nocumenta hominibus et iumentis illata, ex quibus iam violenter reddebatur, tanquam malefica suspecta, cum nemo testis de fidei abnegatione ac carnali spurcitia cum Daemone Incubo adversus eam depposuisset, eo quod illa secretissima. Altamen ubi post nocumenta animalibus et hominibus illata, uti ea respondisset, caetera omnia de fidei abnegatione, et spurcitiis diabolicis cum Incubo Daemnone peractis, interrogata publice fatebatur: assserens se ultra decem et octo annos illi Incubo cum omnimoda fidei abnegatione succubuisse." Ibid., II, Q.1, c.14, p. 161 [Schmidt, II, p. 158]. 
As in the case of so many other witch trials, the employment of judicial torture would have proved to have been a crucial feature of the proceedings, a pattern displayed at Innsbruck as well. ${ }^{163}$ This is attested in II, Q.1, c.15, p. 162 [Schmidt, II, p. 159-60] where Institoris openly acknowledges the employment of torture at Ravensburg, going so far as to claim that Anna Mindelheym's confession, which followed almost immediately from the application of only the first-grade level of torture (i.e. the strappado), was in itself a sufficient indication of the extent of her guilt.

Sed et hoc mirabile, cum sequenti die altera quaestionibus leuissimis exposita primo fuisset, vtpote digito vix a terra eleuata, post libere soluta, praefata omnia, non discrepando in minimo, nec quoad locum, provt altera fassa fuerat, quia videlicet sub tali arbore, et alteram sub alia [...]

The text also hints at the employment of torture in the case of Agnes Baderin.

[...] sequenti mane Balneatrix quaestionibus leuissimis a rectore seu ciuium magistro, fidei zelatore, Gelre cognominato, et ab aliis ex consulibus sibi adiunctis in praesentia notarij exponitur: et licet maleficium taciturnitatis indubie penes se habuisset de quo et semper iudicibus timendum est, eo quod in primo aggressu, non iam muliebri, sed virili animo se innoxiam affirmabat, diuina tamen fauente elementia, ne tantum facinus impune transiret, subito libere a vinculis absoluta, licet in loco torturae, cunta flagitia ab ea perpetrata detexit. ${ }^{164}$

One reason for Institoris' reliance on torture may have been his strong belief in the capacity of witches successfully to withstand interrogation. The problem

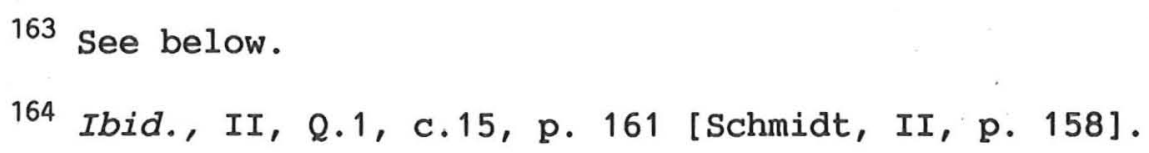


of diabolic silence obviously vexed the inquisitor as he returns to it on several occasions in the text. He makes one brief reference to the phenomenon in II, Q.1, c.12, pp. 150-1 [Schmidt, II, pp. 133-4] in his discussion of his experiences at Innsbruck.

Sunt et tales maleficae quae Iudices solo aspectu et oculorum intuitu maleficare sciunt, quod etiam nullam molestiam eis inferre publice se iactantes: sed vt quibuscunque pro criminalibus causis detentis, et grauissimis tormentis pro dicenda veritate expositis, taciturnitatem inferre sciunt, quod nunquam eorum facinora detegere poterunt.

A more substantial account is provided in II, Q.1, c.2, p. 109 [Schmidt, II, p. 37]

where Institoris alludes to his further inquisitorial activity throughout the region.

Patet ex his quae per dioeceses Argentinensem, Constantiensem, et oppidum Haganoae Ravenspurg. acta sunt, vix annis tribus evolutis. 165 In primo namqua oppido, una vili peplo et fragili suspendit. Altera nomine Vvaltpurgis ${ }^{166}$, de maleficio taciturnitatis miro modo fuit notata, alias mulierculas informando, qualiter talem taciturnitatem per puerum masculum, et primogentium [sic], in fornace decotum, procurare deberent. Acta et gesta adhuc prae manibus habentur: et similiter de aliis in secundo oppido incineratis ${ }^{167}$, sparsim hinc inde deducentur.

165 Presumably this would be either 1483 or 1484 , the year of the proceedings at Ravensburg.

166 This "Vvaltpurgis" is apparently not identical with the "Vvalburgis" of Innsbruck. II, Q.1, c.12, p. 151 [Schmidt, II, p. 134]. See below. She is mentioned a second time in III, $Q .15, \mathrm{pp}$. 247-8 [Schmidt, III, p. 94] though not by name. "Quod ut clarius pateat, malefica quaedam in oppido Haganonae, de qua supra in 2. parte operis tactum est, tale maleficium taciturnitatis procurare sciebat, ut musculus recenter natus, et non baptizatus, et cum hoc primogenitus interemotus, et in fornace assatus, cum aliis rebus, quas exprimere non expedit, incineratus et pulverizatus, si qua malefica aut flagitiosus, ex iis quicquam secum deferret, nullo modo sua crimina fateri posset." 
In III, Q.15, p. 248 [Schmidt, III, p. 96]. the Malleus speculates that there are three means by which suspects are able to maintain silence in the face of torture - natural resilience, the casting of a silence-inducing spell by a witch, or the possession of some sort of magical artefact upon their bodies. ${ }^{168}$ At this point Institoris provides us with one of the few descriptions of the interrogatory techniques he actually employed. After discussing the shaving of the condemned heretics at Regensburg ${ }^{169}$ he contrasts the bishop's procedures with his own.

Et licet in Alemaniae partibus, talis abrasura, praesertim circa loca secreta, plurimum censetur inhonesti: qua de causa nec nos Inquisitores usi sumus: sed tonsis capillis capitis cum calice aut cipho aquae benedictae, guttulam cerae benedictae immittendo, et invocatione sanctissinae Trinitatis ieiuno [sic] stomacho trinies in potum ministrando, per Dei gratiam a plerisque taciturnitatis maleficium abstulimus [sic]. 170

168 "Tertio, quod interdum, licet penses se non habeant maleficia insuta, aut alligata, maleficiuntur tamen ab aliis maleficiis, quantumcunque remotis. Prout malefica quaedam in Issburg [Innsbruck a possible reference to Vvalburgis] se iactare solebat quod ubi ad minus filum ex vestimentis alicuius detenti haberet, tantum efficere posset, quod quantumcunque tormentaretur, etiam usque ad mortem, nihil fateri posset [...]" Ibid., III, Q. 15, p. 248 [Schmidt, III, p.95].

169 See above.

170 Ibid., III, Q.15, p. 248 [Schmidt, III, p. 96]. In this way Institoris also distinguishes himself from the practices of his fellow inquisitor Laurence of $\mathrm{S}$. Agatha. "Tamen in aliis regnis Inquisitores talem per totum corpus ac rasuram fieri mandant. Unde et Cumanus Inquisitor nobis insinuavit, quod anno elapso, qui fuit 1485. unam et quadraginta maleficas incinerari mandasset, omnibus per totum corpus abrasis. Et hoc in districtu et comitatu Burbiae, , vulgariter dicitur Mormbsserbad in confinibus Archiducis Austriae, versus Mediolanum." Ibid., III, Q.15, pp. 248-9 [Schmidt, III, pp. 96-7]. 
The most remarkable feature of the available evidence is the (apparently) high degree of public support and compliance lent to the inquisitorial proceedings. This could possibly be a reflection in part of the papal authority contained within the "bäpstlichen bullen". With this coincided the seeming absence of a local ecclesiastical opposition strong enough to counterbalance the political power that Institoris was able to project. It is noteworthy that Institoris worked exclusively through the secular town council and the lay judicial authorities - there is no mention of any sort of clerical involvement. In II, Q.1, c.15 Institoris specifies that Agnes was interrogated in the full presence of the assembled town magistrates. This might also explain the severity of Anna's and Agnes' punishment; as Richard Kieckhefer has pointed out secular courts were more concerned with the practical expediency of ridding the community of deviants by whatever means, while ecclesiastical courts were devoted to the more costly and time-consuming efforts of repentance and conversion. 171 These attitudes were clearly displayed by Bishop Georg Golser during the Innsbruck trial - unfortunately, for Anna and Agnes no such comparable figure seems to have been present at Ravensburg. ${ }^{172}$ In many 76.

171 Kieckhefer, The Repression of Heresy in Medieval Germany, p.

172 Their single status may also have been a liability - all the other of the accused women appear to have been married. Stadtarchiv Ravensburg U.1116, 1119, 1129, 1131. As Keith Thomas has argued, elderly spinsters or widows often fell easy prey to witchcraft accusations as they lacked the facilities and connections needed to muster an effective defence. Thomas, "The Relevance of Social 
ways Ravensburg appears to be the complete inversion of Innsbruck, where an effective judicial resistance was able to coalesce around a powerful local structure which decisively affected the outcome of the trials.

The origins of the Innsbruck witch trials, the greatest judicial proceeding of Kramer's entire career, appear somewhat obscure, as does the precise nature of Kramer's initial involvement in the affair. Historians have traditionally tended to emphasize the role played by Archduke Sigismund of Austria in both encouraging the trials as well as enlisting Institoris' services. Karl Müller has pointed out that the chancellor of the ducal court during the 1480s, Landislaus Sunthaim, was a distant relation by marriage to Elisabeth Frauendienst, one of those accused at Ravensburg, and could therefore have plausibly served as the "middleman" in drawing Sigismund's attention to the possible utility of Institoris as a witch hunter in the archduke's employ. ${ }^{173}$ In truth, however, the evidence we possess concerning Sigismund's actual involvement is highly circumstantial, the most important bit of which is a laudatory, and highly selfserving, reference provided by Institoris at the end of his summation of the Innsbruck trial in II, Q.1, c.12, p. 151 [Schmidt, II, p. 134] - "Singula haec non ad ignominiam, sed ad laudem et gloriam illustrissimi Archiducis conscripta sunt,

Anthropology to the Historical Study of English Witchcraft" p. 64; Thomas, Religion and the Decline of Magic, pp. 638-80; Cf. also Midelfort, Witch Hunting in Southwestern Germany: 1562-1684, pp. 185-6. p. 409 .

173 Müller, "Heinrich Institoris, der Verfasser des Hexenhammers", 
cum revera uti Catholicus princeps et praecipuus zealator in exterminium earum maleficia cum assistentia, reverendissim, Ordinaris Brixiensis, non mediocriter laboravit." Although Sigismund undoubtedly harboured concerns about the reality of malefic activity - his letter to the mayor of Ravensburg, as well as his instigation of a limited hunt during the Landtag of August 1487 when his former mistress Anna Spiess ("die Spiessin") feigned demonic possession ${ }^{174}$ both attest to the fact - there is virtually no hard evidence implicating the archduke in any direct involvement in the proceedings at Brixen. On 18 June 1485 Innocent VIII dispatched a letter to Sigismund thanking him for the support which he had provided the two inquisitors and commended him to Abbot Johann of Weingarten in the diocese of Constance, who had also apparently provided some services to the Dominicans ${ }^{175}$, but the precise nature and scope of the supposed assistance is never specified. The famous dialogue contained within the De Pythonicis Mulieribus of Ulrich Molitor (1489), of ten cited by historians as conclusive evidence of archducal approval of witch hunting ${ }^{176}$ is, in fact, highly ambivalent as Sigmund is portrayed as a sceptic concerning the value of the persecutions and it is the avowed intent of the other two participants,

174 Baum, Siqmund der Münzreiche, pp. 440-1.

175 Hansen, Quellen, pp. 28-9. Abbot Johann also received a similar such letter from the Pope, likewise dated 18 June 1485 . Ibid., pp. 29-30.

176 Rapp, Die Hexenprozesse und ihre Gegner in Tirol, p. 9; Riezler, Die Geschichte der Hexenprozesse in Bayern, p. 95. 
Ulrich Molitor and Konrad Schatss, to convince him otherwise. ${ }^{177}$ Furthermore, the fact that Institoris openly commends Bishop Georg Golser of Brixen for his aid in the persecution of witches at Innsbruck ${ }^{178}$ when the bishop was the one primarily responsible for thwarting the inquisitor's efforts there, should certainly cast suspicion upon the veracity as well as the sincerity of Kramer's positive assessment of Sigismund's activities.

Whatever the precise course of events preceeding Kramer's involvement at Innsbruck, by July 1485 the inquisitor had taken up residence in the diocese of Brixen, equipped with the Summis desiderantes. It was the papal Bull, in fact, that was to play the crucial political role in the course of events that followed: Kramer's attempts to secure condemnations as well as the bishop's efforts to oppose such blatant inquisitorial advances both centered on a subtle negotiation of the papal power contained within the rescript. The inherently ambiguous political nature of the $\underline{\text { Summis }}$ revealed itself from the very beginning. On 23 July 1485 Golser issued a promulgation of the Summis, granting a forty-day dispensation to all who would actively comply with

177 Molitor, De Pythonicis Mulieribus, passim. In a moment of amazing sobriety, Sigismund touches upon the potentially distorting effect of inquisitorial procedure: "Facile enim dictum sequitur vulgus, nec confessione tortuali satiabor, cum mentu tormentorum quis inducitur quandoque ad confitendum id quod in rerum natura non est." Ibid., p. 19.

178 Malleus, II, Q.1, c.1, pp. 103-4 [Schmidt, II, p. 24]. 
Kramer's efforts. ${ }^{179}$ Two features of this text are immediately apparent. The first is that the bishop pointedly fails to specify the punishments to be administered to the confessed and convicted witches. The second is that he refers to witchcraft as something illusory - "demonum illusiones" - indicating that he understood the maleficia mentioned in the Bull within the context of the earlier theological pronouncements of the Canon Episcopi. ${ }^{180}$ It is evident that Golser understood Kramer's function as an inquisitor of heretical depravity exclusively within the capacity of a preacher, at no point evincing his belief in any malefic occurence within the Innsbruck region that warranted an inquisitorial investigation. ${ }^{181}$ After his customary procedure of delivering a series of sermons denouncing the omnipresent evil of maleficium ${ }^{182}$, Institoris initiated a series of hearings which lasted from 9 August to 14 September and resulted in the collection and examination of depositions given
179 See below, Appendix C.
180 Amman, "Der Innsbrucker Hexenprocess von 1485", p. 79.
181 Ziegeler, Möqlichkeiten der Kritik am Hexen- und Zauberwesen, p. 84 .

182 A duty he performed with apparently uneven results: one of the accused witches at Innsbruck, Helena Scheuberin, was brought before the inquisitor after it had been reported that she had been heard to mutter "Pfei dich, du sneder minch, daz dich das fallend übel in deinen grauwen scheitel sol! Wan fiert der düfel den münch enweg er bredigt nüst dan ketzerei." Amman, "Der Innsbrucker Hexenprozess von 1485", pp. 35-6, 40. This article contains the transcription and critical summary of the extant trial records of the Innsbruck proceedings held at the Fürstbischöfliches Hofarchiv at Brixen, the only known sources of documentation. 
against more than fifty suspects, all but two of whom were women. ${ }^{183}$ So great was the total number of accused that the investigation, although originally intended to be restricted to the town of Innsbruck, must have expanded to incorporate neighbouring parishes as well. ${ }^{184}$ Altogether, at least forty people from Innsbruck and nearby Wilten were accused; likewise, at least ten more from the immediate vicinity and numerous others from various surrounding localities whose names do not appear to have been recorded. 185 The clear majority of the accused came from the peasant classes, although few were of artisan status. No such lines of demarcation were noticeable with the selfproclaimed victims of magical assault, who traversed the entire social spectrum of the community, from labourers to the household of Archduke Sigismund himself. ${ }^{186}$ Golser's increasing scepticism concerning the legitimacy of the proceedings is clearly indicated in a number of letters he issued during the final phase of the proceedings. On 21 September he sent an epistle to Archduke Sigismund which, although acknowledging the bindingness of Kramer's authority

183 The two accused men were Andree Fierer from the parish of Ambos, who was suspected of divining the location of lost objects, and a "Schulmeister" who, aided by his wife Dorothea, was supposed to obtain stolen goods through necromantic practice. Ibid., pp. 22, 13.

184 Ibid., pp. 9-25; Riezler, Geschichte der Hexenprozesse in Bayern, p. 90 .

185 Amman, "Der Innsbrucker Hexenprocess von 1485", p.8. The only other communities explicitly cited are Kemten, Ammeros, and Hal. Ibid., p. 22 .

pp. 128-34]

186 Ibid., p. 25. Malleus, II, Q.1, c.12, passim [Schmidt, II, 
as established by the papal $\underline{\text { Summis }}^{187}$, requested that the Archduke exert his influence on the inquisitor compelling him to restrict his ef forts to those guilty of the more heinious of fenses of malefic bodily harm and, as befitted a German bishop, blasphemy, with penance to be employed as the main disciplining corrective in the milder cases of bewitchment. ${ }^{188}$ That same day he issued a formal letter of episcopal recognition to Institoris, stipulating that the Dominican respect existing legal norms - including the constitution of Boniface VIII which expressly forbade withholding the identities of their accusers from the accused ${ }^{189}$, that he should observe the opinion of the territorial princes in every instance, and that he apply the full force of the law only to those guilty of either the desecration of holy objects or of murder through the employment

187 "Wo ain inquisitor von des heiligen stuels zu Rom wegen chumbt, sein wir schuldig mitsambt dem inquisitor darinn zu handeln und unsern gewalt in auch lassen gebrauchen." Amman, "Der Innsbrucker Hexenprocess von 1485", p. 80 .

188 "[ ...] möcht E.G. mit willen derselben doctor erlangen, oder ob in das auch guet bedunckchen wolt, das die grössern sach als die uner und lestrung gottes mit gayseln und nadeln stechen der gepildnuss, auch wo durch die zawbery die lewdt umb das leben sein chömen und desgleichen strengklich mit urtail fürgenomen und gestrafft [...]". Ibid., pp. 80-1.

189 Perhaps as a result of his experience at Brixen, Institoris insists in III, Q.9. p. 234 [Schmidt, III, p. 62] that this procedure be waived. "Sed an Iudex teneatur eo deponentes manifestere, nec ad conspectum eius praesentare. Hic advertat Iudex, quod nullum illorum tenetur facere, nec nomina manifestare, nec ad conspectum praesentare, nisi deponentes per se et sponte ad hoc se offerunt, ut videlicet eorum aspectibus praesententur, et ea quae deposuerunt eis in faciem obiicere. Quod autem non tenetur Iudex et hoc propter periculum deponentium probatur." 
of malefic techniques. ${ }^{190}$ Through these statements, Golser reveals himself as a rather typical representative of orthodox episcopal opinion, demonstrated by his sceptical attitudes concerning the illusory nature of witchcraft as well as his emphasis upon the offense of blasphemy as opposed to maleficium. It is apparent, however, that the bishop's efforts at moderation met with little success. The records of the depositions and interrogations clearly indicate that Kramer blatantly violated standing ecclesiastical procedure on a number of occasions, including the gratuitous employment of torture. 191

By the beginning of October, Institoris was prepared to bring formal charges against seven of the suspected women - Helena Scheuberin, Barbara Hufeysen, Agnes Sneiderin ("Widow of Peter"), Barbara Pflieglin, Barbara Selachin, Rosina Hochwarin and her mother Barbara Rosalin - all of whom were subsequently incarcerated. 192 Scheuberin was the first to be formally accused on 4 October and from that date until 21 October a total of thirty interrogatory sessions of the women took place. Only Institoris and the papal

190 "Scribimus dicto illustrissimo principi, quatenus favore fidei orthodoxe et pro obedientia apostolice sedi V.P. in executione offitii inquisitionis requisitus iuxta P.V. invocationem assistere ac auxilium ferre et manutenere dignetur, ut huiusmodi gravia peccata evitentur ac emendentur et secundum sacras sanctiones super potestatibus secularibus editas vestris tamquam inquisitoris heretice pravitatis invocationibus satisfaciat et factis vestris acquiescat et ab aliis serenitati sue subiectis hoc idem fieri committat." Amman, "Der Innsbrucker Hexenprocess von $1485^{\prime \prime}$ p. 82.
191 Ibid., pp. 54, 56.
192 Ibid., pp. 35-9, 43-64. 
notary Johann Kanter of the diocese of Utrecht appear to have been present at all sessions. On various occasions, however, the inquisitor was joined by a number of his fellow Dominicans from the immediate vicinity, including Wilhelm Behringer, Heinrich Hoffman, Wolfgang of Basel, Caspar of Freiburg and Magister Johann of Rösbach. He was also at times aided by the Minorite Johann Rosenbart, the court chaplain to Sigismund, as well as Paul Cael Schirmaister. 193

On 7 October, the Archduke wrote to Golser informing him of the imprisonment of the seven women and, perhaps out of concern about an undesirable escalation of the judicial proceedings, requested him to appoint a special episcopal commissioner to advise Institoris and supervise the investigations. 194 Golser duly appointed Sigmund Saumer, a parish priest at Axams and certified Licentiat, as investigator and empowered him to serve as his representative on the episcopal commission to be drawn up to judge the accused, the bishop excusing himself on grounds of ill-health. In a noticeable departure from Kramer's inquisitorial method, Golser also instructed the priest to urge the convicted to return to the body of the Holy Mother Church - "ut redeant ad gremium sancte matris ecclesie". 195

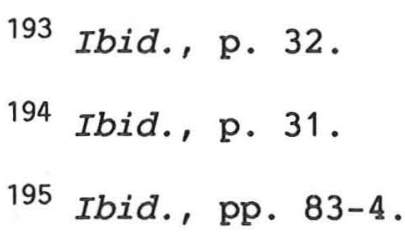


On 14 October Saumer commenced his enquiries ${ }^{196}$ despite Kramer's attempts to thwart him by conducting inquisitorial sessions in his absence 197 - the only interrogation in which Saumer was recorded as being present was the session on 14 October with Helena Scheuberin. ${ }^{198}$ The crisis point was reached during the initial trial proceedings against the accused. A potentially tragic situation rapidly degenerated into farce. The first meeting of the episcopal tribunal took place on 29 October in the town hall, and consisted of the seven commissioners - in addition to Heinrich Institoris, who also served as prosecutor, three local representatives of the Dominican order ${ }^{199}$, as well as Sigmund Saumer, Christian Turner, Licentiat and general commissioner of the church at Brixen, and Magister Paul Wann, doctor of theology and canon law from Passau - aided by the two public notaries Johann Kanter and Bartholomäus Hagen. ${ }^{200}$ Helena Scheuberin was the first of the accused to be presented before the court, where she was interrogated by Institoris concerning her moral status within the community and her sexual practices. This provoked an

\footnotetext{
196 Rapp, Die Hexenprozesse und ihre Geqner in Tirol, p. 6.

197 Ziegeler, Möglichkeiten der Kritik am Hexen- und Zauberwesen, p. 89 .

198 Amman, "Der Innsbrucker Hexenprocess von 1485", p. 37.

199 Kramer apparently selected these representatives from a short list of those five Dominicans who had previously aided him in the interrogation of suspects - Wilhelm Behringer, Wolfgang of Basel, Caspar of Freiburg and Magister Johann of Rösbach. Ibid., p. 66.

200 Ibid., p. 65.
} 
immediate response from the other members of the commission who overruled this kind of questioning as irrelevant and threatened to remove Institoris from the session if he continued with this line of enquiry. At the same time, Saumer, acting within his capacity as episcopal commissioner, accused Kramer of severe procedural irregularities during the previous phases of the investigations and called for a short recess of the trial until Institoris had formally drawn up an official set of questions. During the resulting interim, Golser's agents made their move, recruiting the services of Johann Merwais of Wendingen, a doctor of medicine and a Licentiat of canon law, to act as defendant of the accused. $^{201}$ Merwais proved his worth at the reconvention of the commission at 11 a.m.. His first move was to call for an indefinite postponement of the trial, allowing him time to acquire the of ficial certification he needed to serve as defendant lawyer of the accused who had, by this time, both individually and collectively, consented to transfer the conduct of their defense to the Licentiat. Merwais pressed his case, declaring all proceedings hitherto null and void, Institoris having undermined his own position on five points of gross procedural misconduct: that the inquisitor had failed to obtain a public notary certified by the bishop to supervise and record the conduct of the interrogations as was specified by the Summis; that the inquisitor had brought against the defendants accusations of crimes that technically lay outside his jurisdiction and which

201 Ibid., p. 67. 
were, in any case, not explicitly mentioned in the Bull; that Institoris should have asked each of the accused about the nature and contents of the depositions made against them but had failed to do so owing to his neglect in formulating a standard questionnaire; that the Dominican had imprisoned the seven accused women even before any of ficial judicial procedures had formally been initiated; and that the inquisitor had conducted all phases of the investigation, including the procurement of the testimonies of the accused in the absence of a public notary authorized by Golser. ${ }^{202}$ A long verbal duel between prosecutor and defendant followed, Merwais openly rejecting Kramer's status as a judge on grounds of partiality and called for his replacement by the bishop as well as the deacon and the vicar-general of the diocese of Freising. Grounding his opposition firmly on the basis of Kramer's apparent deviations from the stipulations of the Summis, Merwais requested that Institoris be placed in custody and the accused released. Following Kramer's strenuous protests, Merwais accepted the commission's decision to subject the accused to less stringent conditions of imprisonment. Merwais then continued his efforts to undermine Kramer's position by instructing the accused to ignore the questions of the prosecutor altogether, and to reply only to the queries put to them by the episcopal commissioner himself. While Merwais called for a direct appeal to the papal chair, thereby circumventing the political status bestowed on Kramer by

202 Ibid., pp. 67-9. 
the Bull, Institoris vigorously defended his right to remain as judge. Clearly recognizing that they had failed altogether to halt Kramer's initiative during the first session of the trial, the episcopal representatives on the committee agreed with the Dominican faction to reconvene several days later at a different locale to review the validity of Merwais' objections. 203

The second, and final, session met on the morning of 31 October in the house of Conrad Gunther, a prominent burgher of the community. Taking advantage of the unexpected interlude, Golser subtly strengthened his hand by providing for the appointment of two new members to the commission, Ulrich Puchter, chaplain of Innsbruck and priest of the diocese of Naumburg, and Johann Blanckenhayn, a "Cooperator", both of whom must certainly have been strongly sympathetic to the bishop's position. The new session began with a direct clash between the prosecutor and the defendant, Merwais reiterating his demand for an appeal to the Curia in the face of Kramer's strenuous opposition. Merwais finally relented and offered the compromisory solution, found acceptable by the committee, that the commission indefinitely postpone its trial of the accused until it had extensively reviewed the legality of Kramer's actions. Although failing in his grander ambitions, Merwais, by obtaining the commission's acceptance of his proposal, had succeeded in securing his minimal objective, the recognition of the impropriety of Kramer's handling of the 
proceedings, thereby relinquishing himself from the more formidable task of of fering positive proof of the innocence of the accused. In his capacity as general commissioner, Turner proceeded to declare the trial invalid "invalidatum seu invalidandum" - on the grounds of the inquisitor's misconduct and had the women released, but, significantly, only after they had declared their willingness to appear before a future court that might be convened to investigate the charges levelled against them. Turner of ficially nullified the episcopal recognition bestowed upon Institoris by Golser and demanded the return of the original copy of the notice. So vigorous were Kramer's protests, that Turner consented to confine himself to lodging a formal complaint against the inquisitor through the public notary Bartholomäus Hagen. The final pressing issue of the trial, namely financial renumeration, was resolved through the direct intervention of the archduke himself who, later on that same day, promised to subsidize the cost of the proceedings, as well as rewarding Institoris for services rendered, but refused to guarantee any form of financial support for any sort of further investigation or trial. 204

Although down Institoris was by no means out, refusing to leave Innsbruck even after his humiliating disgrace before the court. It was only at this point, after his men had effectively undermined Kramer's position that Golser took direct action against the inquisitor. Raising fears concerning the potential of 
a popular uprising following the witchcraft proceedings, the bishop wrote to Institoris on 14 November urging him to quit Innsbruck as he could no longer guarantee his safety.

Quia aliquorum animos exasperatos intellexi contra vestram paternitatem, ideo visum est omnio paternitatem vestram avizare debere, ut a loco isto discedatis pro hoc temporum conditione et dequanto cicius tanto comodius. Plures defatigati sunt et processum paternitatis vestre estimant insolitum seu graniter ferunt. Ideo tamquam is, qui scandala et pericula debet quomodo submovere seu intercipere, avizo paternitatem vestram, ut se conferat ad locum solite residentie et non manere in hoc loco: id conducit plurimum (scio quid scribo). Nequaquam scribo sine misterio aut leviter. Ideo in meliorem partem accipere scripta mea dignetur paternitas vestra, quam cupio bene valere. 205

The first of the bishop's not-so-subtly-veiled threats obviously failed in its purpose, as Kramer continued to reside in the Tirol, purportedly busying himself with the collection of new evidence for a further set of witchcraft accusations. By 8 ' February 1486, Ash Wednesday, the bishop felt compelled to take further action. In a letter addressed to a priest named Nikolaus, Golser lamented the deterioration of Kramer's intellectual faculties - "Ich find in des babst bullen, das es bey vil bäbsten ist vor inquisitor gewesen, er bedunckt mich aber propter senium gantz chindisch sein worden, als ich in hie zu Brichsen gehört hab cum capitulo... Ich meuss ex officio ordinario derinn handeln und bedarff sein gar nit der zue" 206 - and instructed him to convey to the inquisitor an additional

Ibid., pp. $84-5$.

206 Ibid., p. 86. 
missive blatantly informing him of the acute undesirability of his continued presence.

Venerabilis doctor. Miror valde, quod manetis in diocesi mea et in loco ita vicino curie, in qua errores sunt sommissi et perventum ad dissensiones ne dicam scandalu. Gratiosissimus dominus archidux honorifice dotavit vos, ut sic recederetis in pace. Non videtur accomodum, quod intromittat se paternitas vestra de illis personis, sed onus incumbit mihi. Usque modo non fuit datum loqui cum domino principe de hac materia, sed adhoc faciam attento quod mihil fructuose fieri posset sine sue excellentie assistentia. Verendum est, ne mariti mulierum vel amici possent paternitatem vestram of fendere. Non indigos in agendo presentia vestra, que plus posset impedire quam conferre; ego auctoritate ordinaria faciam que videbuntur expedire. Certe paternitas vestra declinare deberet ad suum monasterium sicut prius persuasi. Non deberetis aliis esse molestus. Sepe dixi paternitati vestre, quod nihil faceretis in diocesi, pro hac temporum conditione sed exiretis. Ita etiam putabam vis diu recessisse. 207

This letter obviously produced the desired effect, and Institoris withdrew immediately afterwards, presumably to Salzburg. 208

Several features of the Innsbruck proceedings deserve comment. The first, as has already been mentioned in passing, is the extreme ambivalence of the role played by Duke Sigismund. Several factors indirectly attest to Sigismund's general lack of support for the trials - the close ties between the archduke and the bishop as displayed in the September correspondence; his apparent silence following both the commission's annulment of Kramer's episcopal authority on 31 October and Golser's attempts to evict the inquisitor

\footnotetext{
207 Ibid., p. 87.

208 Müller, "Heinrich Institoris, der Verfasser des Hexenhammers", p. 409 .
} 
in November and February; and his refusal to finance any additional trial proceedings. It seems the most plausible conclusion that while Sigismund did not agree with the manner in which the inquisitorial investigations were conducted his detachment from the proceedings was the result of his reluctance to become directly embroiled in an ecclesiastical dispute between warring parties of papal and episcopal authority. ${ }^{209}$ Such transparency is unfortunately not the case concerning the role played by Bishop Golser. Certainly, the non-Dominican members of the episcopal commission could have acted neither as effectively nor as blatantly against Institoris as they did without the bishop's tacit support. Within this context, Golser's own intellectual attitudes towards maleficium acquire some interest. ${ }^{210}$ There are sufficient indications that he was harboring some sceptical attitudes, if not concerning the reality of maleficium as such, then at least against the specific connotations given to it by the scholastic demonology propagated by a Realist Dominican such as Institoris. As we have already seen, Golser largely reaffirms the position of the Canon Espiscopi concerning the illusory nature of supposed p. 96 .

209 Ziegeler, Möqlichkeiten der Kritik am Hexen- und Zauberwesen,

210 One certainly cannot go as far as Wolfgang Ziegeler in viewing the bishop as a proto-enlightenment representative of early modern rationalism, purportedly the result of his humanistic education at the University of Vienna, coupled with the legacy bequeathed by Nicholas of Cusa, Golser's predecessor as bishop of Brixen. Ibid., p. 110. Ironically, Cusa himself expressly sanctioned the prosecution of two women on charges of maleficium. Blauert, Frühe Hexenverfolqungen: Ketzer, Zauberer und Hexenprozesse des 15. Jahrhunderts, p. 35. 
demonic magic. ${ }^{211}$ Furthermore, even though he specifies that bodily harm or death resulting from maleficia should be severely punished, he does not explicitly advance a view on the presumably demonic causal agency underlying such occurrences, the theological lynchpin of the emergent witchcraft ideology. The crucial point is that Golser never identifies magic with heresy. 212

Theological concerns - the nature and status of occult transgression - thus neatly dovetailed with more conventional political factors, in this case a subtle and sustained negotiation of the power contained within the papal Summis. In some ways the witch trial of Innsbruck almost seems to reduplicate in miniature certain crucial features governing the general relationship between episcopal and papal-inquisitorial authority. The entire ground of resistance of fered to Institoris was not centered on a denial of the reality of malefic supernatural agency as such but rather, very much like the later opposition of the Cologne

211 See below, Chapter Six.

212 "Man könnte daraus folgern, daß er [Golser] möglicherweise unter dem Eindruck der Bulle und ihrer päpstlichen Autorität - schon eine verbindung zwischen zauberei und Kezerei sah bzw. nicht prinzipiell ausschloß. Seine Strafvorstellungen bezüglich zauberei widersprechen dem allerdings; sie bewegten sich offensichtlich im Rahmen des Herkömmlichen und bezeugen deutlich einen Unterschied zwischen Zauberei und Ketzerei $(\ldots)$. Für Zaubereivergehen wünschte er offensichtlich, soweit rechtlich irgend möglich, Milde walten zu lassen. Umsomehr mußte er sich an dem rigorosen Vorgehen des Inquisitors stoßen. Die große Anzahl der Verdächtigen scheint bei dem bedachtsamen Bischof aber auch Zweifel ausgelöst zu haben, ob die angeblichen Verbrechen überhaupt geschehen seien. Jedenfalls hielt er den Ketzerrichter für höchst überflüssig. Dies könnte andeuten, daß des Institoris Praxis für ihn vielleicht nur der Vorwand war, ihn fortzuschicken, ohne sich den Vorwurf illoyalen verhaltens gegenüber dem Papst zuzuziehen." Ziegeler, Möqlichkeiten der Kritk am Hexenund Zauberwesen, p. 95. 
Theology Faculty ${ }^{213}$, on the inquisitor's infringements of canonical jurisprudence perpetrated in the pursuit of his own conception of the nature of demonic threat. The distinguishing characteristic of the Innsbruck affair was the tremendous and unique political status granted to Institoris through the Summis desiderantes and the conflicting ways in which this authority was interpreted by the rival parties. Golser's oppositional efforts, mirrored in his basic scepticism concerning the particularities of the scholastic paradigm of demonic agency, were therefore based upon a strategy of neutralizing Kramer's political authority: that is, by illustrating Kramer's own deviations from the prescriptions of the Bull, the keystone of his apparently unassailable power. It is significant that at least two of Merwais' accusations of procedural misconduct were, in fact, groundless - the $\underline{\text { Summis }}$ does not specify that a duly appointed episcopal notary must be present during interrogations; furthermore, the evidence reveals that, whether officially empowered by Golser or not, the notary Johann Kanter was in fact present at most sessions. ${ }^{214}$ What was at stake here, of course, was the desperate pursuit of the only strategy of resistance available to the episcopal authorities that could eventually prove to be politically efficacious - the demonstration of Kramer's own flagrant abuse, and thus the nullification, of that very authority invested in him by the curia.

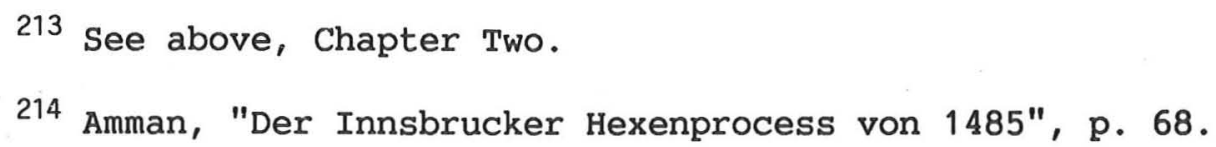


Supporting this interpretation is the intriguing fact that even though the seven accused were ultimately released, they still had to promise to appear before any further court of inquiry that might be held in the future. This indicates that the episcopate was more concerned with countering the danger of inquisitorial excess than denying the possibility of diabolic deviancy, a possible threat which it obviously preferred to handle on its own terms within its own capacities.

Although a clear victory for Golser, the fiasco in the Tirol produced the unexpected result of convincing Institoris that he should continue his pursuit of demonic transgressors by other means. ${ }^{215}$ The Brixen ordeal left its mark upon Institoris and, through him, upon the Malleus, not only with regards to the original impetus to compose the text so as to negate the baleful effects of sceptical clerics ${ }^{216}$, but also concerning the development of certain key features of the basic argumentative structure of the treatise itself. The initial depositions of the Innsbruck trial are situated within the context of the general witchcraft beliefs of western Austria; a comparison to Institoris' reproduction of these accounts within the Malleus reveals the manner and extent to which the

215 "Die Niederlage in Innsbruck dürfte seinen Wunsch nach einem umfassenden Handbuch aller theoretischen und praktischen Belange der Hexenverfolgung so verstärkt haben, daß der Inquisitor innerhalb kurzer Zeit alle seine Vorarbeiten zu dem systematisch geordneten Hexenhammer vereinigte." Dienst, "Magische Vorstellungen und Hexenverfolgungen", pp. 78-9.

216 E.g. Malleus, I, Q.18 - "Sequitur modus Praedicandi, contra quinque argumenta laicorum, quibus probare videntur sparsim quod Deus non permittat tanatm potestatem Diabolo, et maleficis, circa huiusmodi maleficia inferenda" - passim, [Schmidt, I, pp. 206-16]. 
inquisitor sought to perpetrate the diabolic heretic stereotype by demonizing the notion of magical causality through the introduction of the principle of diabolic agency, a central feature of the discursive apparatus infusing the text. 


\section{CHAPTER FOUR:}

THE MALLEUS, "HEXENGLAUBE" AND WOMEN AS WITCHES.

The whole of Part Two of the Malleus might best be regarded as a grand quasi-encyclopaedic summation of popular superstitious beliefs and practices reformulated by Institoris and re-presented to the reader in such a manner as to effect the automatic identification of the local village cunning (wo)man with the heretical satanic deviant. From II, Q.1, c.6 to c.15, pp. 126-62 [Schmidt, II, pp. 75-161] Institoris dutifully lists veritably the whole array of popular beliefs concerning the witch - weather magic, body magic, the infliction of impotency and demonic possession. ${ }^{1}$ He also includes some notions that were definitely not prevalent within popular culture such as the witch as infanticidal mid-wife ${ }^{2}$ - inclusions, that may be regarded as Kramer's own rather indiscriminate discursive imperialism, appropriating whatever popular notions happened to resemble the heretical stereotype and recasting them in accordance with his pre-given discursive practice. In every instance, however, it is the demonic causal agency that is systematically postulated by the inquisitor as underlying the particular phenomenon. To render this crucial feature of the text fully

\footnotetext{
1 See below, Chapter Six.

2 For example, Malleus, I, Q.11, p. 68 [Schmidt, I, pp. 157-9].
} Although midwives were often perceived as homicidal, there is little evidence of their being connected to diabolic witchcraft on the popular level. See Dienst, "Lebensbewältigung durch Magie", p. 96; Harley,"Historians as Demonologists: The Myth of the Midwife-witch", passim. See below, Chapter Seven. 
intelligible, it must be situated within the context of fifteenth-century witchcraft beliefs and practices.

Of the estimated five hundred witch trials that took place throughout western Europe from 1300 to 1500 , official depositions for only twenty-one survive, three from Germany, three from France, and fifteen from Switzerland. ${ }^{3}$ Most of the Swiss records originate from the diocese of Lucerne - in Germany, we possess the records from Straßburg, 1451; Constance, 1458; and, most important for my purposes, Innsbruck, 1485.4 The situation in Austria is particularly ambiguous as it is difficult to trace any sort of structural continuity underlying the various waves of prosecutions. 5

In general, Austria was renowned for its high degree of religious orthodoxy and stability, only a handful of limited regional prosecutions against suspected

3 Kieckhefer, European Witch Trials, p. 28.

4 Ibid., p. 159.

${ }^{5}$ Dienst, "Magische Vorstellungen und Hexenverfolgungen", p. 91. "Vergegenwärtigen wir uns die im Vorstehenden ausgewählten Beispiele [from the Innsbruck trial], so ergibt sich zwingend, daß weder ein einheitlicher Hexenbegriff aus ihnen gewonnen noch eine monokausale Erklärung für die Verfolgeungen geboten werden kann. Weder waren nur ländliche Gemeinden noch nur soziale Unterschichten noch nur Frauen von ihnen betroffen, um einzelne in letzter zeit vieldiskutierte Elemente herauszugreifen. Wenn auch kein Zweifel daran bestehen kann, daß der Hexenbegriff der theologischen Dämonologie, gekennzeichnet durch den Bund mit dem Gegengott, der der Teufel ja eigentlich ist, durch Hexensabbat und Teufelsbuhlschaft, zur Formulierung des todeswürdigen zauberischen Verbrechens und damit zu seiner Verfolgung geführt hat, so hat doch die Existenz des volkstümlichen, aus einer umfassenden magischen Weltsicht resultierenden Verständnisses von (Schaden-) Zauber und der allgemeine Glaube an die Wirksamkeit magischer Handlungen den abstrakten Begriff der Theologen erst mit Leben erfüllt; die furchtbaren Konsequenzen entstanden schließlich aus der verbindung von beidem. Die Art ihrer Interferenzen war im einzelnen unterschiedlich..." Ibid., p. 90. 
heretics, namely Waldensians and Flagellants, occurring sporadically throughout the fourteenth century ${ }^{6}$, although individual instances of burnings of local striga were not unknown, especially within the Tirol region. Though not probable, the staging of a full-scale persecution of witches was certainly possible within and around the locale of Innsbruck. ${ }^{7}$ In general, however, magic was not subject to criminal proceedings by judicial officials on a large scale until the middle of the sixteenth century. Whereas the crime of heresy had been subject to inquisitorial procedures for some time ${ }^{8}$, proceedings against witchcraft and magic, both of which could be separated from heresy only with great difficulty ${ }^{9}$ did not really take place until the promulgation of the Constitutio Criminalis Carolina in $1532 .{ }^{10}$ This imperial decree served as the judicial basis of the state-sanctioned persecutions of satanic malefactors within the German territories throughout the sixteenth and seventeenth centuries. Article 44 declared guilty of the crime of witchcraft all those who engaged in magical activities, of fered to teach magic to others, threatened others with

6 Bernard, "Heresy in Fourteenth-Century Austria", pp. 50, 56-7.

7 Dienst, "Lebensbewältigung durch Magie", p. 112.

${ }^{8} \mathrm{Cf}$. Robert Lerner's discussion of the disastrous deliberations, and resultant etymological errors of the Council of Vienna in 1312 . Lerner, The Heresy of the Free Spirit, pp.78-84.

9 See below, Chapters Five to Seven.

10 Emperor Maximilians's Halsqerichtsordnung for the Tirol, issued in 1499, does not specify magic as a crime. Dienst, "Magische Vorstellungen und Hexenverfolgungen", p. 73. 
heretics, namely Waldensians and Flagellants, occurring sporadically throughout the fourteenth century ${ }^{6}$, although individual instances of burnings of local striga were not unknown, especially within the Tirol region. Though not probable, the staging of a full-scale persecution of witches was certainly possible within and around the locale of Innsbruck. ${ }^{7}$ In general, however, magic was not subject to criminal proceedings by judicial officials on a large scale until the middle of the sixteenth century. Whereas the crime of heresy had been subject to inquisitorial procedures for some time ${ }^{8}$, proceedings against witchcraft and magic, both of which could be separated from heresy only with great difficulty ${ }^{9}$ did not really take place until the promulgation of the Constitutio Criminalis Carolina in $1532 .{ }^{10}$ This imperial decree served as the judicial basis of the state-sanctioned persecutions of satanic malefactors within the German territories throughout the sixteenth and seventeenth centuries. Article 44 declared guilty of the crime of witchcraft all those who engaged in magical activities, of fered to teach magic to others, threatened others with

6 Bernard, "Heresy in Fourteenth-Century Austria", pp. 50, 56-7.

7 Dienst, "Lebensbewältigung durch Magie", p. 112.

${ }^{8}$ Cf. Robert Lerner's discussion of the disastrous deliberations, and resultant etymological errors of the Council of Vienna in 1312 . Lerner, The Heresy of the Free Spirit, pp.78-84.

${ }^{9}$ See below, Chapters Five to Seven.

10 Emperor Maximilians's Halsgerichtsordnung for the Tirol, issued in 1499, does not specify magic as a crime. Dienst, "Magische Vorstellungen und Hexenverfolgungen", p. 73. 
harmful magical acts, maintained close contact with practising magicians or witches, or had the reputation of being a magician or witch. Article 58 provided regulations concerning the application of torture in the investigation of all capital crimes, placing magic in the same legal category of murder, high treason, grand theft, and arson; as had been previously established in the development of Roman jurisprudence, torture could be considered applicable if no confession of guilt was forthcoming during the initial phases of interrogation. ${ }^{11}$ By the middle of the seventeenth century, more decisive measures had been taken by the imperial government to secure the condemnation of satanic deviants. The Neue peinliche Landgerichtsordnung of Ferdinand III was passed in 1656 , closely following the Malleus concerning the identification and interrogation of suspects. Further ef forts to standardize the application of inquisitorial torture in the pursuit of diabolic elements came in 1679 following Leopold II's issuance of detailed sets of instructions regulating the behaviour of the of ficials of the local government of Niederösterreich after a series of large-scale witch trials there. ${ }^{12}$

By and large, though, Austrian authorities paid comparatively little attention to the supposed misdeeds of diabolic cunning folk. By the time the

11 Die Peinliche Gerichtsordnung Kaiser Karls V. von 1532 (Carolina), pp. 50, 56. Cf. also ibid., Article 52, "So die gefragt person zauberey bekent", pp. 53-4.

12 Dienst, "Magische Vorstellungen und Hexenverfolgungen", p. 73. 
major hunts began towards the end of the Thirty Years' War ${ }^{13}$, the focus of attention was concentrated on the subversive activities of those populations which resisted the control of local authorities, such as vagrants and beggars. ${ }^{14}$ As R.J.W. Evans has pointed out, witch hunting "challenged superstition in order to enhance conformity. Social control, to go with religious control, lay in the interests of all those with a position to preserve, from the solider kind of peasant upwards. It forms another aspect of the pursuit of settled hierarchy." 15 It seems likely that the concern with witch hunting as a means of controlling vagrancy explains the striking preponderance of male victims within the Habsburg territories. ${ }^{16}$ This is well evidenced by the notorious Zauberjackl trial held at Salzburg from 1675 to 1690 , resulting in the execution of at least two hundred male vagrants. ${ }^{17}$ A further correlation was established between diabolic vagrants and gypsies, who were regularly suspected

4 .

13 Evans, The Making of the Habsburq Monarchy: 1550-1700, pp.402-

${ }^{14}$ Dienst, "Magische Vorstellungen und Hexenverfolgungen", p. 85.

15 Evans, The Making of the Habsburq Monarchy: 1550-1700', pp. $411-12$.

16 Ibid., pp. 411-12.

17 Dienst, "Magische Vorstellungen und Hexenverfolgungen", pp. 85-6. "It is significant of the official mentality that it attributed (or connived in attributing) magical powers to [vagrant populations]. Sorcery not only became an extra measure of their guilt: it indicated that diabolic origin of all misdeeds, including their responsibility for otherwise inexplicable disasters like plague." Evans, The Making of the Habsburq Monarchy: 1550-1700, p. 413. 
of black magic and various superstitious practices, primarily mundane forms of divination. The main problem created for the authorities in identifying the vagrant with the witch was that "an uneasy marriage between approval and disapproval of magic" was set up. "Accusations of witchcraft demanded that people credit outlaws with supernatural powers for evil; the trouble was that deprived and discontented elements within organized society might well invest them with a beneficient occult role", as happened with Oleksa Dovbuš, Juro Janošik, and the mythical folk hero Rübezahl. ${ }^{18}$ In Austria, then, the close interrelation between witch hunting and the more explicitly political concerns of population control and surveillance are particularly evident.

Such macro-political concerns did not necessarily prevail on the village level, where concerns with witchcraft remained within the microscopic realm of the interpersonal ${ }^{19}$, magical beliefs permeating the life of the everyday. $^{20}$ Once again, the ambiguity of the surviving evidence restricts analysis. $^{21}$ This uncertainty even extends into the realm of the etymological,

18 Ibid., pp. 413-14. Cf. Eric Hobsbawm on the supernatural outlaw as champion of popular justice. "The bandit's invulnerability is not only symbolic... It is almost invariably due to magic, which reflects the beneficient interest of the divinities in his affairs." Hobsbawm, Bandits, p.51.

19 Von Hehl, "Die Hexenprozesse der frühen Neuzeit", p. 263.

20 Dienst, "Lebensbewältigung durch Magie", p. 113.

21 "The sources for the fourteenth and fifteenth centuries do not permit exhaustive analysis of the social context of witchcraft accusations and trials." Kieckhefer, European Witch Trials, p. 93. 
as the terms provided by of ficial sources by no means always necessarily comply with contemporary popular usage, such sources being themselves the product of the scholastic interpretatio theologica. There is apparently little popular terminological basis for a clear and distinct definition of the concept of witchcraft. $^{22}$ As best can be determined, the most prevalent terms for witches were $U_{n h o l d e n}{ }^{23}$, usually employed in the feminine form, or the more common Zauberer or Zauberin, a "magician" or "sorcerer", denoting someone who practises magic in some capacity without necessarily demonic overtones. The most commonly employed popular Latin term seems to have been striga, a "screech-owl" or vampiric nocturnal spirit, malefica being a much later addition to the popular vocabulary, a possible symptom of the wide dissemination of the scholastic discourse of witchcraft. Surprisingly, Hexe was rarely used in Austria. The word itself, derived from hagazussa, "one who rides on a fence", conveys an inherent double meaning: it connotes a woman who actually achieves aerial transport with demonic assistance, but it can also suggest a woman who walks along fences, that is, who instigates unrest between neighbours. ${ }^{24}$

\footnotetext{
22 Horsley, "Who Were the Witches?", pp. 695-6.

${ }^{23} \mathrm{Cf}$. the town mayor's letter to Sigismund provided in Appendix B.

24 Dienst, "Magische Vorstellungen und Hexenverfolgungen", p. 77; Russell, Witchcraft in the Middle Ages, pp. 15-16. For an extended discussion of the wide and totally unsystematic usages of the various terms for witch, refer to J. Frank, "Geschichte des Wortes Hexe", in Hansen, Quellen, pp. 614-70, as well as the lengthy entry under "Hexe" in the Handwörterbuch des Deutschen Aberqlaubens, III, 1827-1919.
} 
Etymological factors provide crucial insights into the meagre evidence we possess concerning the social reality of Hexenglauben. As the term hagazussa implies, witchcraft accusations were generated by tangible, personal misfortunes and by real hostilities between neighbours. ${ }^{25}$ It is difficult to demonstrate conclusively whether late medieval accusations were primarily an urban or rural phenomenon. ${ }^{26}$ What does appear indisputable, however, is that the witchraft practices which did occur and the resultant accusations that sprang from them were firmly grounded upon a thoroughly magical view of the world and a notion of (supra)physical causality thoroughly entrenched within popular culture. "In their improvisations, the cunning folk were inventing a kind of science to deal with a magical universe, working within a framework of a mental world that persisted into the seventeenth century and beyond." 27 This magical "science", however metaphysical its foundations, was invariably employed in the pursuit of wholly practical goals - "Witch beliefs provide[d] villages with a symbolism for comprehending the sole preoccupation of their lives: the survival and health of themselves, their animals, and their crops." 28 The pursuit of mundane

25 Garrett, "Women and Witches: Patterns of Analysis", p. 463.

26 Kieckhefer, European Witch Trials, pp. 94-5.

27 Garrett, "Witches and Cunning Folk in the old Regime", p. 58.

28 Ibid., p. 55. For extensive discussions of the thoroughly pragmatic nature of witchcraft beliefs and activities refer to Thomas, "The Relevance of Social Anthropology to the Historical Study of English Witchcraft", pp. 54-68; Thomas, Religion and the Decline of Maqic, Chs. 7-9; Macfarlane, Witchraft in Tudor and Stuart Enqland, 
economic objectives could easily intersect with the exhibition of intense personal rivalry within the matrix of witchcraft practices. 29

On the basis of the judicial records, it would appear as though body magic $^{30}$, love magic $^{31}$, weather magic $^{32}$, and theft magic, mainly of milk 33 , were the main varieties of magical practices performed on the popular level in the German-speaking alpine regions. Notwithstanding the fact that the actual techniques employed in magical operations were seldom recorded ${ }^{34}$, several general observations can be offered. The first concerns the structural affinity between body and love magic. Body magic usually entailed the infliction of physical harm to men and/or animals, through either some variety of image (homeopathic) magic or, more usually, the ingestion of some magical

Chs. 13-15; Macfarlane, "Witchcraft in Tudor and Stuart Essex", pp. 85-97.

29 "Magie wurde eingesetzt zunächst und überwiegend zum Schutz vor allen unglücklichen Wechselfällen des Lebens, zur Wiederherstellung von Gesundheit, Liebe, sozialer Stellung und Besitz, aber auch - und das ist die notwendig zum Glückszauber dazugehörige Kehrseite der Angelegenheit - zur gewaltsamen Lösung von Konflikten, zur schweren Schädigung, zur Vernichtung des Gegners." Dienst, "Lebensbewältigung durch Magie", pp. 115-16.

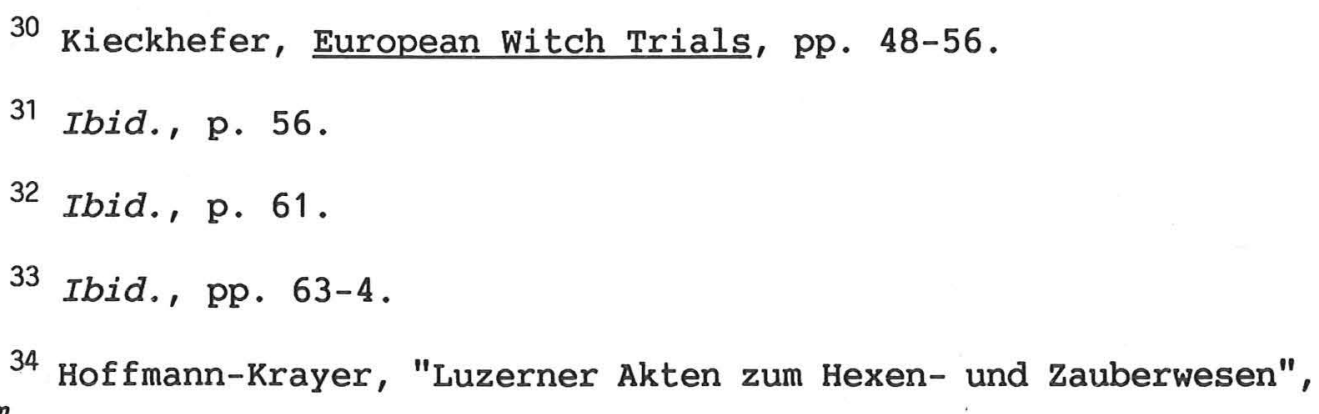
passim. 
item or substance, necessitating some rudimentary form of physical contact. 35 Although the nature of magically induced illnesses is seldomly cited in the documents, the usual type of malady that appears to have resulted could easily have been of either physical or psychosomatic origin - lameness, migraine, blindness, arthritis, gout, impotency ${ }^{36}$, and delirium. ${ }^{37}$ Fully fifty per cent of all recorded cases of magical illness resulted in fatality 38 though a large portion of these deaths could easily have been the result of failed attempts at curing. It is striking that very of ten those tried for witchcraft were of ficially designated in the judicial record as peasant healers, medicus or medica. 39 It also reflects the inherently ambivalent status of the village healer within the community, as occult practices could easily be deployed for malefic purposes. ${ }^{40}$ Love magic partook of this ambivalence in that it could be used

35 Kieckhefer, European Witch Trials, pp. 48-9.

36 Masculine fears of sexual impotence through bewitchment is traceable as far back as the penitentials of the tenth century. Cohn, Europe's Inner Demons, p. 151.

37 Dienst, "Lebensbewältigung durch Magie", p. 102; Kieckhefer, European Witch Trials, p. 54. The possible psychosomatic origins of these disorders could attest to the prevalence of those psychological tensions and guilt complexes presumably resulting from the interpersonal conflicts underlying the actual accusation of bewitchment. Cf. Bever, Witchcraft in Early Modern Wuerttemberq, passim.

38 Kieckhefer, European Witch Trials, p. 56.

39 "Healers of this kind would be especially susceptible to prosecution because their remedies frequently combined herbal lore with religious practices, and the latter could easily be construed as superstitious or even as mockeries of Christian devotion." Ibid., p. 56.

40 Horsley, "Who Were the Witches?", p. 698. 
either to induce erotic sentiments or to inflict death ${ }^{41}$ - like body magic, it employed the same basic techniques, the administration of portions being the most common method ${ }^{42}$, which, of course, required the intended victim's direct contact with the magical substance. ${ }^{43}$

The second observation is that word magic reflected the inherently ambiguous metaphysical status of the witch in a remarkably direct fashion. Although Richard Kieckhefer claims that neither incantations nor inscriptions of magical spells figured largely in the trial records from the late Middle Ages $^{44}$, an examination of the judicial proceedings from Innsbruck clearly reveals that the utterance of curses was one of the most common methods of producing magical effects ${ }^{45}$, the curses interpreted as magical by those who

41 Kieckhefer, European Witch Trials, p. 57. The Malleus provides an exceptionally graphic account of the potentially lethal nature of love magic. "Novimus vetulam, tres successive Abbates, ut publica omium fratrum fama in illo monasterio etiam in hodiernum diem refert, non solum in his maleficiasse [sic], sed et interemisse, quartum iam simili modo dementasse. Quod et ipsa publica voce fatetur nec veretur dicere, seci et facio: nec desistere a meo amore poterunt, quia tantum de meis stercoribus comederunt, quantitatem per extensum brachium demonstratndo. Fateor autem, quia nobis non aderat ulciscendi et inquirendi super eam facultas, ideo adhuc superest." Malleus, I, Q.7, pp. 50-1 [Schmidt, I, pp. 117-18]. Here the inquisitor may be investing an obscene gesture with maleficient significance.

42 Ibid., p. 57. Also see Brucker, "Sorcery in Early Renaissance Florence", pp. 10-12.

43 Kieckhefer, European Witch Trials, p. 59.

44 Ibid., p. 65.

45 Amman, "Der Innsbrucker Hexenprocess von 1485", p. 9-23. 
believed themselves to have suffered the effects of verbal invocation. ${ }^{46} \mathrm{~A}$ possible explanation for the apparent indiscrepancy was the marginalization of verbal magic following the rise of Christianity, which disrupted the conditions necessary for the perpetuation of a low magical culture.

For two main reasons pre-Christian society was able to maintain incantation as an important form of sorcery. First... the lack of effective sanctions probably allowed frequent practice of sorcery, so that verbal formulas could be shared and transmitted from one sorcerer to another. Second, maleficient magic was practiced freely by literate as well as illiterate classes, so that such formulas could likewise be passed on through the written medium. ${ }^{47}$

It is quite possible, therefore, that Christian society successfully impeded the transmission of "formula" spells with a rigidly fixed ritual wording, forcing practitioners to improvise their own private, and idiosyncratic "saying" spells and that it was only the incantation of the latter category that irregularly found its way into the trial records. For these purposes, ecclesiastical ritual and prayer could be easily adapted for popular magical usage. The Malleus itself provides several outstanding examples of such a development. In II, Q.2, c.6, pp. 193-4 [Schmidt, II, pp. 235-6] Institoris relates how a devout virgin - "Nam fertur de quadam virgine paupercula, et ideo plurimum devota" - cured a man through reciting the Lord's Prayer and making the Sign of the Cross, afterwards

\footnotetext{
46 Dienst, "Lebensbewältigung durch Magie", p. 102.

47 Kieckhefer, European Witch Trials, p. 67.
} 
berating him for his lack of faith ${ }^{48}$; the author then devotes the rest of the chapter to laying out a long series of guidelines stipulating what forms of popular religious ceremonies and invocations intended to counter harmful magic may be considered theologically acceptable. ${ }^{49}$ Even more telling, in II, Q.2, c.7, pp. 204-6 [Schmidt, II, pp. 261-5] Institoris declares that the protective magical practices of certain Swabian women he has encountered are acceptable because the rituals observe proper respect for the Articles of Faith. 50

The problem concerning the witch's capacity to effect magical transformation verbally directly relates to the question of the ontological recognition bestowed upon the wise woman by the community. There is good, albeit indirect evidence that lay folk attributed a supernatural power directly to the person of the witch herself, a power fundamentally distinct from the external operations she practiced. "The source of 'witchcraft'... lies not in

48 The account is taken from Nider, Formicarius, v, c.4, p. 357.

49 See below, Chapter Six.

50 Institoris provides an interesting comment that touches directly upon the classificatory nature of the text: "Nec valet si obiicitur. Deus contulit, sicut herbis, 7 lapidibus. Quia si quae virtutes insunt quibusdam verbis, aut sacramentalibus, aut aliies benedictionibus \& carminibus. licitis, has habent in se, non ut verba, sed ex institutione, \& ordinatione Divina, \& ex paeto Dei. Sicut si Dominus diceret: quicunque hoc fecerit, faciam ei hanc gratiam: Et sic verba in sacramentis efficiunt quod signant. Quamvis secundum alios etiam habent virtutem intrinsecam: Sed prima opinio, quia iam deservit, ideo amplectenda: De aliis autem cerbis \& carminibus, patet ex praemissis, quod ut verba sunt composita, vel proluta, aut figurata nihil efficiunt, sed invocatio nominis Divini \& obsecratio, quae est per sacra quaedam protestation, ad committendum effectum divinae voluntati prosunt. Remedia etiam operum, quae illicita videntur, ut supra tactum est." Malleus, II, Q.2, c.7, p. 204 [Schmidt, II, p. 260]. See below, Chapter Six. 
techniques but in the person: the witch is full of destructive power" ${ }^{151}$ - a consideration underscored by the fact that the very term maleficium originally implied mis-deed or ill-will; from the fourth century onwards it was employed as a specific term connotating malevolent harm manifested through occult means. 52 The rituals of protective counter-magic amply demonstrate that "even amongst the peasantry of the early Middle Ages, centuries before the full stereotype of the witch came into being, it was recognized that the motive for maleficium was of ten sheer malice." 53 Although clear-cut distinctions are impossible to draw, especially as they do not seem to have been recognized by the people themselves ${ }^{54}$, a general pattern of belief may be discerned.

By some mysterious power the accused (allegedly) has malevolently done harm to the accuser in some way. Occasionally this has been accomplished by some magical technique, but usually... it has been done by virtue of an inexplicable power which is inherent in or possessed by the accused, perhaps manifest only in a glance ${ }^{55}$ or a strange comment. Besides the occasional use of more explicit magical techniques by the witches, however, we also encounter - in evidence such as the Lucerne depositions $^{56}$ - various forms of counter-magic employed by the 16,65

51 Cohn. Europe's Inner Demons, p. 147.

52 Ibid., p. 148; Russell, Witchcraft in the Middle Ages, pp. 15-

53 Ibid., p. 152.

54 Middleton and Winter, "Introduction", p. 2.

55 For magical assault through eye-contact, see Gifford, The Evil Eye, passim; Roberts, "Belief in the Evil Eye in World Perspective", pp. 223-78.

56 Cf. Hoffmann-Krayer, "Luzerner Akten zum Hexen- und Zauberwesen", passim. 
accuser-victim in retaliation against the accused. There would appear to be in European folk practices, therefore, a basis for making the same analytical distinction made by many anthropological treatments of nonEuropean cultures 57 , i.e. a basic distinction between witchcraft and sorcery, between witches and sorcerers. Witchcraft is done by means of an inherent or implicit power possessed by the witch, whereas sorcery is performed by means of an explicit technique learned or acquired by the sorcerer. 58

Not only are witchcraft and sorcery different in kind, but they are also different in function; maleficium was more properly the domain of sorcery whereas more economically useful forms of magic, such as divination or healing, were performed by the "wise woman". 59

The third and most important observation, inextricable from the second, concerns the essentially non-satanic popular notion of the witch. Contemporary depositions and accusations are concerned almost exclusively with specific acts of maleficium; the devil himself is absent. 60 The archetypal notion of the demonic witch was the hybrid produce of the interaction between popular beliefs and the ecclesiastical resistance to popular superstitions as mediated through

57 Cf. also Evans-Pritchard, "Sorcery and Native Opinion", pp. 25-7; Witchcraft, Oracles, and Maqic Among the Azande, pp. 1-17.

58 Horsley, "Who Were the Witches?", pp. 695-6.

59 Ibid., p. 699.

60 The following historians have found no mention of the devil in the surviving deposition accounts that they have worked on - Byloff, Hexenglaube und Hexenverfolgung in den österreichischen Alpenländern, pp. 1-42; Heberling, "Zauberei und Hexenprozesse in SchleswigHolstein-Lauenburg", pp. 117-25; Hoffmann-Krayer, "Luzerner Akten zum Hexen- und Zauberwesen", passim; Schwarzwalder, "Die Formen des Zauber- und Hexenglaubens in Bremen", passim; Tobler, "Zum Hexenwesen in Bern", passim. 
the efforts of scholastic theologians to diabolize all magical practices and beliefs. ${ }^{61}$ As Richard Kieckhefer has argued, the populace "adhered to the simpler belief in the power inherent in a witch or her actions whereas the learned elite insisted repeatedly that the witch herself has no magical powers, amd that all she does, she does through the mediation of demons".62 This trend is readily apparent in II, Q.1, c.14, pp. 158-9 [Schmidt, II, p. 152] of the Malleus, when Institoris discusses Anna of Mindelheym's alleged slaughter of horses.

Dum autem capta et interrogata fuisset, per quam modum talia efficisset? respondit, nil se aliud nisi, foveam fecisse, qua facta, Diabolus certas res imposuisset sibi ignotas. Qua ex re colligitur, quod tamtammodo aut manum, vel visum apponere habent: et hoc ut quoquo modo malefica cooperatur. Alia enim Diabolo sueviendi in creaturas facultas non permitteretur, ubi malefica non concurreret, ut prius tactum est, et hoc contingit propter maiorem of fensum divinae maiestatis.

Here it is obvious that Institoris has taken a popular belief - the inherent power of the witch to do harm through her own will, perhaps facilitated by external technique - and actively reappropriated it so as to render it consistent not only with the stereotype of the satanic heretic but also with the concomitant neo-

61 Schweizer, "Der Hexenprozess und seine Anwendung in Zürich", pp. 10-11. "From all the valid evidence available it appears that diabolism was not the original charge [brought against witches], but was superimposed in the courtroom on some prior accusation, usually sorcery. The introduction of diabolism can thus plausibly be construed as resulting from a desire of the literate elite to make sense of the notion of sorcery. On this interpretation the concern with diabolism arose more from intellectual needs than from psychological grounds." Kieckhefer, European Witch Trials, pp. 78-9.

62 Ibid., p. 83. 
Aristotelian position of regarding magical efficacy as a product of demonic agency, a capacity acquired by the witch through the entrance ${ }^{63}$ into a formal relationship of apostasy with Satan.

It is profitable to examine Kramer's own account of the Innsbruck proceedings, which he provides in II, Q.1, c.12, pp. 148-51 [Schmidt, II, pp. 12834] in relation to the employment of his discursive strategy. In many ways Innsbruck was a community ideally suited to the generation of those interpersonal conflicts that fostered accusations of witchcraft. Situated along the main trans-Alpine trade routes between Italy and Germany, Innsbruck had, by the end of the fifteenth century, succeeded in establishing itself as the center of a rapidly expanding local economy. In 1420 Archduke Friedrich IV transferred his princely residence to the town, bringing in his wake large numbers of ducal courtiers as well as a substantial portion of the Austrian gentry. The population not only swelled in numbers - approximately five thousand by 1500 - but the entire class network underwent extensive restructuring, with resultant social stress to be expected. Throughout the second half of the fifteenth century the native middle-class elements were steadily displaced by the influx of the new courtly elite. By the 1480 s, forty per cent of the total population were of middle-class status. Beneath them, twenty

63 See below, Chapter Seven. "It is important.. to recognize the prime significance of the pact as a means for placing the devil at the service of the witch, so that the witch's desires might be carried out with an almost mechanical regularity by the devil." Ibid., p. 86. 
per cent of the total enjoyed full Bürger privileges, while an additional twenty per cent, though of ficially excluded from the Bürger status, nevertheless still enjoyed considerable prosperity - the great majority of the members of both these elites were directly employed in the service of the ducal administration. Apparently, personal competition through aggressive conspicuous consumption was intense, display of clothing and of living space the primary means of showing off social differentiation. 64

Within such a highly stratified and competitive social framework, marriage and sexual relationships, licet or otherwise, assumed exceptionable importance for the inhabitants, especially female, in establishing and guaranteeing their position within the social hierarchy. 65 Accordingly, sexual jealousy and conflict served as one of the primary stimulants to both performances as well as accusations of bewitchment. Out of the total of thirty-two separate deposition accounts held at Brixen, sexual jealousy or some variety of marital dispute involving sexual misconduct accounts for no fewer than five occurrences of maleficium. ${ }^{66}$ There are four cited incidents of either impotency or a loss

64 Dienst, "Lebensbewältigung durch Magie", pp. 80-5. Dienst bases her account on a wide variety of local and specialized studies of the Tirolean and western Austrian regions dating from 1883 to 1985 . Cf. her footnote entries nos. 1-32. Among the topics covered in her sources are the history of mining and the salt mines, the professional and trade structure of Innsbruck, demographic trends, and the development of the ducal court.

65 Ibid., p. 113.

66 Amman, "Der Innsbrucker Hexenprocess von 1485", pp. 14-15, 16, $19,20-1$. 
of sexual desire as a result of malevolent love magic ${ }^{67}$ as well as two further general references to the practice of such magic. ${ }^{68}$ Altogether, there are six cases of murder attributed to the body of love magic worked by the Kleuberin of Hettingen ${ }^{69}$, Elsa, "die Böhemmin" 70 , the Old Rendlin 71 , Ennli Scheurin $^{72}$, and Helena Scheuberin ${ }^{73}$. In every instance, the cause of death was ascribed to a magical substance placed either within the household or near the person of the victim. Some of these items ${ }^{74}$ include bristles, animal hair, chalk, spiders, and woollen thread. ${ }^{75}$ The overt sexual symbolism of some of the items utilized in love magic, such as nuts ${ }^{76}$, pubic hair ${ }^{77}$ and the heart

67.

Ibid., pp. 12, 18, 20-1, 22 .

68 Ibid., pp. 10, 15.

69 Ibid., p. 9.

70 Ibid., p. 11

71 Ibid., p. 14.

72 Ibid., p. 20.

73 Referred to in the depositions as "die alt Scharerin" - Ibid., p. 11 - and "die Zwschrettin" - Ibid., p. 12.

74 The Innsbruck trial records contain one of the richest accounts of the items and contents of the practice of popular sorcery. Cf. Dienst, "Lebensbewältigung durch Magie", pp. 109-12.

75 Amman, "Der Innsbrucker Hexenprocess von 1485", pp. 16.

76 Ibid., p. 12.

77 Ibid., p. 16. 
of a black $\operatorname{cock}^{78}$ are almost too obvious to merit comment. The crucial topic of consideration is the multiplicity of erotic concerns that underlay not only magical practice but also fears of bewitchment.

78 Ibid., p. 19. 
Kramer's own account of the Innsbruck proceedings in II, Q.1, C.12 is surprisingly brief, detailing only six incidents of maleficia, none of which can be traced directly back to the original testimonies provided in the depositions. Institoris claims that his brevity is necessitated by the enormity of witcheraft activity within the Tirol region.

Sed sic singula, quae in illo duntaxit oppido reperta sunt, recitare vellem, liber utique foret conficiendus. Quanti enim caeci, claudi, aridi, et diversis irretiti infirmitatibus, iuxta formam iuris, ex vehementi suspicione super maleficas eis huiusmodi infirmitates, in genere vel inspecie praedicentes, et quod talia brevi sentire haberent, vel ad dies vitae, vel ad mortem statim percipiendum. Et quod secundam eorum dictu et avisamenta cuncta accidissent vel ad specificatum infirmitatem, vel ad mortem aliorum. 79

The only generalization that he allows himself to make following this rather disingenuous disclaimer is that witchcraft is most commonly precipitated by sexuál envy arising out of male abuse of women.

Quia enim terra illa vasallis et - armigeris 80 , et otia dont vitia ubi interdum mulieres procabant, dum illas procutas abiicere, et alias honestas matrimonio sibi copulare disposuerunt, rero sine vindicta super mleficium inferendum, aut viro aut uxori, dum se spretas cernebant: thorus coniugalis perseuerabat, non autem viris tantum quantum mulieribus: eo ut pie nestimari, potest illis interemptis, aut arefactis,

79 Malleus, II, Q.1, c.12, p. 150 [Schmidt, II, p. 132].

80 A possible reference to the knight Jörg Spiess, allegedly murdered by Helena Scheuberin - Amman, "Der Innsbrucker Hexenprocess von 1485", pp. 35-9. Elsewhere in the chapter - Malleus, II, Q.1, c.12, p. 150 [Schmidt, II, p. 133] - Institoris makes passing reference to a certain soldier who was killed by witchcraft: "Sic denique per maleficia miles quidam, ut publica fama testatur, interemptus fuit, sic \& alii plures, quos recitare omitto." 
priores amasias procure haberent. 81

Institoris clearly postulates frustrated marital ambitions and/or abused sexual desires as a primary incentive leading women to practice witchcraft at several points in the Malleus $^{82}$; in his discussion of the natural affinity women possess for maleficia in I, c.6, p. 43 [Schmidt, I, p. 100], Kramer reiterates the basic point - "Et revera potissima causa deserviens in augmentum Maleficarum est dolorosum duellum inter maritates et non maritates foeminas, et viros: immo et inter ipsas foeminas sanctas, quid tunc de caeteris."

Besides the predominant concern witch sexual matters, the other outstanding feature of the witch proceedings at Innsbruck is the absence of any overt reference to Satan or to diabolism. In the deposition accounts, the sole reference to the devil took place on 6 September, when Trenlin, the daughter of Roetfelder, was accused of stealing milk after a neighbour had hung a bucket of milk over the fireplace and struck it while invoking Satan's name, imploring him to reveal the identity of the thief. ${ }^{83}$ Kramer's own role as a mediator in interjecting the notion of satanic deviancy into the account of the proceedings is particularly apparent in the case of Ennel Notterin, a baptized Jewess. On 16 and 18 August, Ennli Sippin, Bärbel Casper-Smidin, and Sigmund

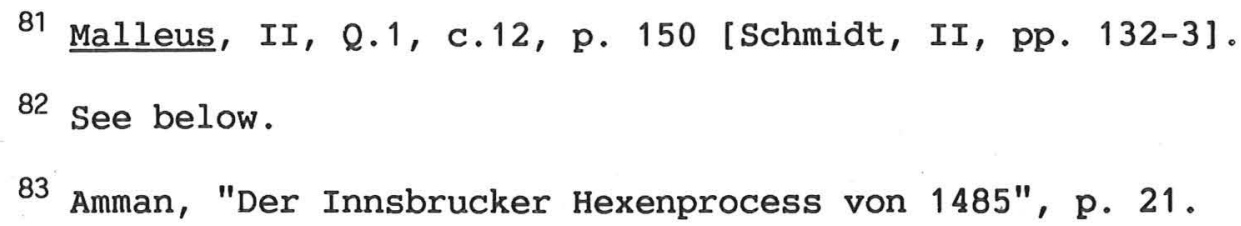


Smid brought charges of blasphemy against Notterin, Enli Heintz, and Appolonia, the wife of Jergen Buechsenmaister, herself recently deceased, purportedly murdered by Helena Scheuberin. 84 According to the witnesses, the three accused met in the household of Casper Smidin's wife five years previously to scourge a martyr image of Christ and to utter blasphemous words against God.

Ennel Notterin, ain getauffte iüdin, und Ennli Heintz satelknecht uxor, und ein, die Appolonia hiess, die tot ist, die andern leben noch, die haben an einem aben vor fünf iaren ein marterbild Unsers Heren gegaiselt und darzw vil lesterlicher wort gesprochen wider got. Daz hat die Appolonia den zügen gesait, die in der zedil stent. 85

Furthermore, Smidin's wife claimed that she witnessed the Notterin utter a blasphemous chant against the Mother of God.

Item die Barbel Caspar Smidin, in deren haus es gescheen ist, spricht, daz die Ennle gaiselt daz bild, aber die getauffte iüdin die ret ybel auch von Unser Lieben Frauwen, "Daz dir werd also we in deinem sin, als der Márien wart in irer krin [i.e. vulva], do sy Jesum gebar". 86

The actual nature and meaning of the event behind the accusations remains obscure; the highly rhythmical quality of Ennel's curse strongly suggests that it was of a popular nature ${ }^{87}$, perhaps an inversion of a blessing 88 as a means

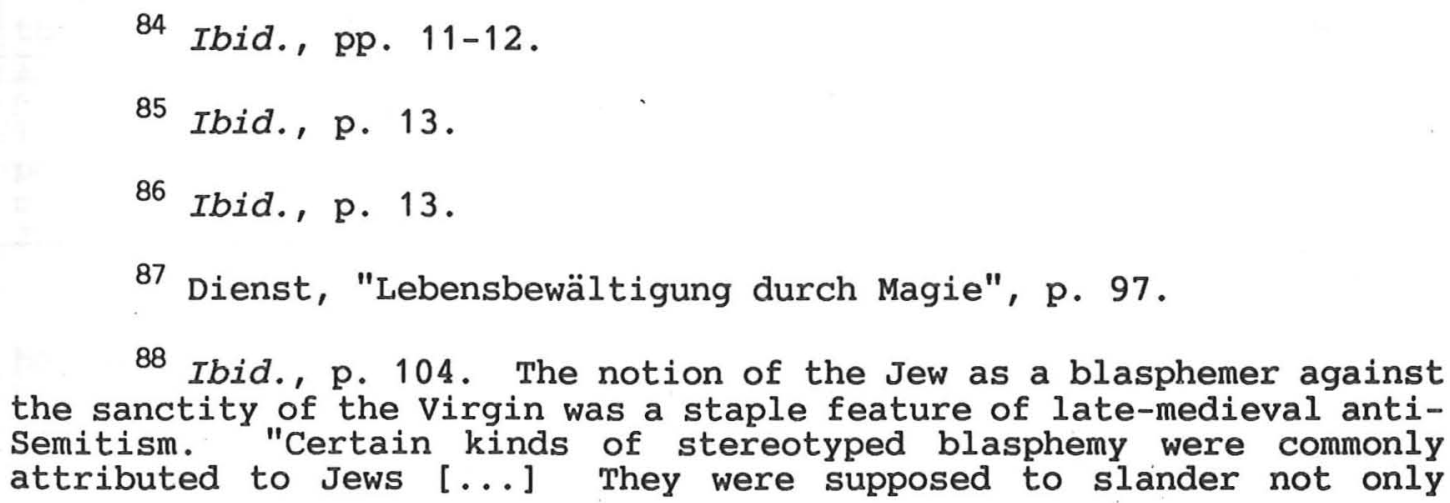
the sanctity of the Virgin was a staple feature of late-medieval antiSemitism. "Certain kinds of stereotyped blasphemy were commonly attributed to Jews [...] They were supposed to slander not only 
of expressing anti-ecclesiastical sentiments. Institoris, however, seizes this incident as being representative of the heretical sabbat, investing it with the full discursive significance of the demonological paradigm in his discussion in II, Q.1, c.12, p. 151 [Schmidt, II, p. 134] of the Malleus;

Sunt et quae imaginem crucifixi flagellis et cultris impigendo, ob maleficia perpetranda, cum turpissimis verbis, contra gloriosissimae virginis Mariae puritatem, et nostri salvatoris ex eius intemerato uteri nativitatem dehonestaverunt: verba illa, et singulos actus recitare non expedit, cum nimis sint piorum aurium offensiva in scriptis tamen redacta et resposita sunt: prout baptizata quaedam Iudea et alias inuenculas induxerat, quarum una Walburgis ${ }^{89}$ nomine eodem anno in extremis posita, dum a circunstantibus ad confessionem peccaminum hortaretur exclamavit: corpus et animam tradidi Diabolo, nec spes mihi adest veniae, et sic defuncta.

Not only does Kramer utilize the widespread tradition of the Jew as sower of unbelief and blasphemy ${ }^{90}$, but he also manages skilfully to weave together an array of stereotypical images pertaining to witchcraft coalescing around a core historical incident whose fundamental nature is irretrievably altered

Christ's divinity but also his birth and character, depicting him as magician and seducer, justly condemned as a criminal by the Jews; and they were said to call the Virgin a whore." In Venice in 1563, the young son of a converted Jewish family was supposed to have claimed "'that Christ was a bastard born of carnal sin when the Virgin Mary had the menstrual blood upon her'." Pullan, The Jews of Europe and the Inquisition of Venice 1550-1670, pp. 80-1. Cf. also, Hsia, The Myth of Ritual Murder: Jews and Magic in Reformation Europe, pp. 69, 119; Trachtenberg, The Devil and the Jews, pp. 118-19, 120, 121, 186.It is possible that Notterin could have been engaged in some sort of popular magical ritual that was (mis)interpreted by witnesses as a form of Jewish blasphemy.

89 It seems unlikely that this is the same Walburgis mentioned in Malleus, II, Q.1, c.2, pp. 108-9 [Schmidt, II, pp. 29-30] and in III, Q.15, pp. 247-8 [Schmidt, III, p. 94]. See above.

90 Cf. Dienst, "Lebensbewältigung durch Magie", p. 97. 
through the process of transmission. It is with incidents such as these that one may perceive most clearly the subtle intermeshings of both scholastic discourse with empirical fact giving rise to the formation of a wholly new discursive object to be subjected to both theological knowledge as well as to juroinquisitorial power.

The evidence provided by the trial records touches directly upon one of the most notorious and widely discussed features of the Malleus - the text's equation of satanic malefice with female sexuality. 91 The Malleus, by rigorously employing an Aristotelian sexology, succeeds in establishing a circular network of mutually re-enforcing referents signifying the necessary correlations between femaleness, sexuality, and diabolism. By incorporating in a systematic fashion orthodox scholastic doctrine on sexual differentiation with the broader legal and social questions concerning the relationship between women and maleficia, the Malleus succeeds in formulating a discursive framework that is not only in total accord with of ficial theological and medical doctrine, but also throroughly self-consistent with its own basic intellectual premises - women's mental inferiority is the product of a physical deficiency which reveals itself through enhanced sexual desire, frequently resulting in a form of sexual behaviour understood as symptomatic of satanic deviancy; women's physical

91 Joseph Hansen argues that one of the primary features of the Malleus is its identification of witchcraft with femaleness. Hansen, Zauberwahn, pp. 473-501. 
inferiority results in a limited capacity for intellectual development which is repeatedly exploited by Satan as a means of obtaining ever greater numbers of heretical adherents who announce their allegiance through displays of sexual deviancy. The text thus succeeds in providing an internally coherent intellectual explanation for a widely experienced social phenomenon, the necessary relationship between women and witchcraft, that renders the entire problem intelligible within the context of its own philosophical outlook, a discursive framework that both legitimizes and legislates a series of interrelated juropolitical concerns and objectives, namely the identification, classification, and prosecution of malefic diabolic heretics.

References to the relationship between femininity and maleficia recur periodically throughout the text, though most of ten in a fairly undeveloped manner. In II, Q. 1, c.1, pp. 101,2 [Schmidt, II, p. 20] the text insinuates that economic hardship of ten compels women to of fer their allegiance to diabolists.

Daemones per maleficas tantis afficiunt damnis in temporalibus, vicinos et innoxios ut quasi coacti, maleficarum suffragia primo habeant implorarae, et demum earum consiliis se submittere, experentia saepe nos edocuit [...] Quantae denique mulieres in officio inquisitionis, nobis existentibus conquestae fuerunt, quod dum propter damna vaccis, ex privatione lactis, et aliis iumentis illata, suspectus maleficas consuluissent, etiam remedia oblata percepissent, dummodo aliquid uni spiritui promiterre voluissent. et illis inquirentibus, quidnam promittendum foret, respondebant parum hoc esse dummodo informationibus illius magistri assentiret, super certas observantias, tempore divinorum in Ecclesia, aut in confessionibus faciendas sacerdotibus aliqua subticendo assentirent.

A complex array of associations are established here - women are attracted to 
witchcraft not only because of their sex but also because of their domestic function. The text also indicates that such malefic "defections" are part of a single, organized demonic conspiracy, individual witches acting as agents of subversion on Satan's behalf, attempting to obtain recruits for some sort of diabolic "anti-Church". Such suggestions are taken much further in the text's discussion of several incidents of the attempted seduction of young girls by elderly witches. These accounts subtly blend together the traditional stereotypes of diabolic heresy and sexual perversion - more specifically, pederasty. Linkages between satanic conspiracy and female sexual licentiousness are established most clearly in II, Q.1, c. 4, p. 122 [Schmidt, II, p. 68].

Finaliter vero concluendo, dici potest ipsos Daemones Incubos, non tantum mulieribus ex eorum spurcitiis progenitis, aut oppidi per ipsas maleficas sedutrices aut copulatrices anhelare. Hoc enim experientia, rerum magistra, edocuit: ubi in oppido Ravensburg certae combustae ante finalem sententiam hiuic simile asserverunt, quod eis ab earum magistris iniunctum fuisse, omni canatu debere in subversionem sanctorum virginum et viduarum laborare.

In II, Q.1, c.1, p. 102 [Schmidt, II, pp. 21-2] the Malleus relates the attempts of

Agnes Balderin to seduce the innocent under demonic instruction.

Nam in oppido Ravenspurg ex duabus incinceratis 92 , prout etiam inferius patebit, ubi de modo quem observant, concitando tempstates tangetur, una illa Balneatrix inter alia, quae fassa fuerat, hoc etiam recitavit, se multas a Diabolo fuisse perpessam iniurias, ea de causa, quod

92 The text clearly specifies that only two witches were burned in Ravensburg. 
virginem quandam devotam, et filiam cuiusdam praedivitis, (quem nominare non opus est, cum et ipsa iam defuncta sit, disponente divina clementia, ne malitia depravaret cor eius,) seducere deberet, taliter ut ipsam festivo aliquo die invitaret, ut ipse Daemon in speciei inuensis, cum ea sua colloquia habere posset. Addiderat etiam quod licet saepissime hoc facere attentasset, semper tamen ubi inunculam fuisset allucta illa signo sanctae crucis se munivit. Et hoc utique e instinctu sancti Angeli, ad effugandum opera Diaboli processisse nemo dubitat. 93

The Malleus also provides an anecdote concerning the attempted seduction of

a virgin of Straßburg in II, Q.1, c.1, pp. 102-3 [Schmidt, II, pp. 22-3].

Est et alia in diocesi Argentinensi constituta, quae uni ex nostris confessa, asservit, quod die quadam Dominica dum Solitaria in domo paternaincederet, vetula quaedam illius oppidi ipsam visitandi. [G]ratia accesit, et inter alia scurrilia verba quae protulerat, haec ultimatim subintulit, ut eam si placeret, ad locum ubi iuvenes omnibus hominibus oppido praebuissem et ipsam subsequuta ad domum venissem vetula subintulit, Ecce per gradus ad cameram superiorem ascendimus, ubi iuvenes morantur, sed caveas ne signo crucis te munias, quod dum me facturam asservissum, illa praecedente, ego per gradus sequendo, occulte me signo crucis muniri. Unde contigit, quod in summitate graduum, et ante cameram pariter constitutae, illa vetula horribili vultu, et Stomachato anomi se vertendo, et me aspiciendo dixit: En maledicaris, cur signo crucis te signasti? ab hinc in nomine Diaboli recedas: sicque ad propria reij illaesa.

A similarly lurid tale is related by the servant-girl of Breisach in II, Q.1, c.2, p.

93 Similar activities are also attributed to Anna of Mindelheym. "Praefata deniquie balneatrix incinerata, per hunc, madum asservit, ab aliqua quadam vetula se seductam cum tamen eius consodalis differenti modo: quia videlicet Daemonem in via in specie humana invenisset, cum et ipsa intentionis fuisset, amasium suum fornicationis causa visitare: et ubi a Daemone Incubo cognita fuisset, et interrogata, an eum cognosceret, et ipsam se rerum minime agnoscere affereret. Ille respondit. Daemon cum, et si volueris ad tuum beneplacitum semper ero paratus, nec in quibuscunque necessitatibus te deseram? Ad quae, illa dum annuisset, decem et octo annis usque videlicet ad ultimum vitae, spurcitiis illis diabolicis inservivit, cum fidei tamen omnimodo abnegatione." II, Q.1, c.1, p. 103 [Schmidt, II, p. 23]. 
106 [Schmidt, II, p. 30].

Quadam enim die secum per gradus ascendere iubebat, et eius iussu cameram intrare, ubi cum vidisset quindecim iuvenes in vestimentis viridis coloris, ad modum quo Reuthero incedere solent, mater tera sibi dixit: Elige ex his iuvenibus, et eum quem volveris, tibi tradam, et ipse te sibi in sponsam assumet: et cum illa nullam se velle habere asservisset, graviter vulnerata tandem acquievit, modum exprimens praemissum $[. . .]^{94}$

These graphic anecdotes notwithstanding, the text's only extended systematic demonstration of the necessary connection between femaleness and diabolism is provided in I, Q.6, pp. 40-7 [Schmidt, I, pp. 92-109], entitled "Quoad ipsas maleficas Daemonibus se subiicientes". Little of the following text is actually devoted to an exposition of the issues raised in its rather lurid title, and the basic argument is both simple and repetitive. Institoris commences with a bold declaration: "Quo ad primum, cur in sexu tam fragili mulierum maior multitudi Maleficarum reperitur, quam inter vicos. Et quidem in contrarium argumenta deducere non expedit, cum ipsa experientia, praeter verborum et fide dignorum testimonia talia facit credibilia." 95 This is the first of two striking characteristics of the chapter, both of which merit extended discussion. Rather than basing his argument upon a logical deduction from hypothetical first principles ${ }^{96}$, Institoris presents the association between women and witchcraft

94 See below, Chapter seven, for a discussion of the text's development of the notion of the Sabbat.

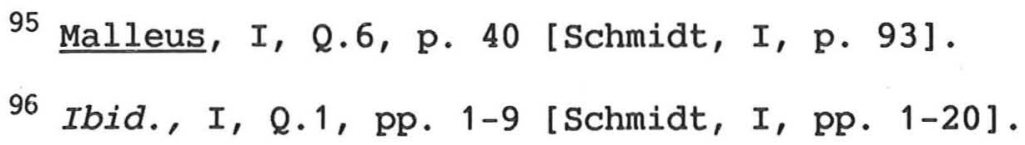


an empirically verifiable social fact, a given contingency that is simply passively repeated by the author and not actively argued for. It is only subsequent to the initial factual assertion that Institoris attempts to demonstrate its veracity through an appeal to authority: Seneca, Cicero, Cato, Socrates, and Terence are all cited as leading experts on the inherent wickedness of women. ${ }^{97}$ One of the chapter's suprising features, its comparative lack of scriptural sources concerning misogyny - the rather obvious exception of the story of Joseph taken from Genesis notwithstanding - is readily explained when the Bible's own highly ambiguous attitude towards women is taken into account. Apart from the benevolent examples of Judith, Deborah, and Esther, Institoris follows the New Testament in general, and Saint Jerome in particular, in emphasizing the redemptive power of the Mother of God in reversing the First Sin incurred by Eve, a topic of great concern to numerous writers, both theological and chivalric, during the later Middle Ages. ${ }^{98}$

Et dicere quod licet in veteri testamento, scripturae ut plurimum mala loquuntur de mulieribus, et hoc propter primum praevaricatricem mulierem, scilicet, Evam, et imitatrices eius, tamen et post in novo

97 It is interesting that Institoris relies primarily upon classical authors for demonstrating his misogynistic position. This would situate the text within the general revival of humanistic education in the latter part of the fifteenth century; likewise, it reveals an attempt to add even greater authoritative force to the text's sexological speculations, hinging as it does upon an applied neo-Aristotelianism. See below.

98 Monter, "The Pedestal and the Stake", pp. 119-36. 
testamento propter mutationem nominis, ut Eva in Ave (ut ait Hiero.) ${ }^{99}$ Totum quod intulit maldeictio Evae, totum abstulit benedictio Mariae. 100

No sooner is the beneficent image of the Virgin evoked, however, than it is immediately dropped, replaced by the main argumentative thread of Kramer's misogynistic stance. Once again, Institoris offers empirical proof for the validity of his claim, this time coupled with the pretence of scientific argument.

Sed quia ad hoc modernis temporibus, haec perfidia [witchcraft] amplius in mulieribus, quam in viris invenitur, ut ipsa experienta docet, curiosus causam investigando, ultra praemissa dicere possumus, quod in omnibus viribus, tam animae, quam corporis, cum sint defectuosae, non minim, si plura maleficia in eos, quos aemulantur, sieri procurant. 101

Institoris offers three main reasons for the general propensity of women to engage in malefice. The first is that women are, by nature, more credulous than men and therefore easier prey for Satan - "quia pronae sunt ad credundum: et quia principaliter Daemon, quaerit corrumpere fidem, ideo potius eas aggreditur"102; the second is that they are in general more impressionable than men, especially in spiritual matters 103 - "quia a natura propter

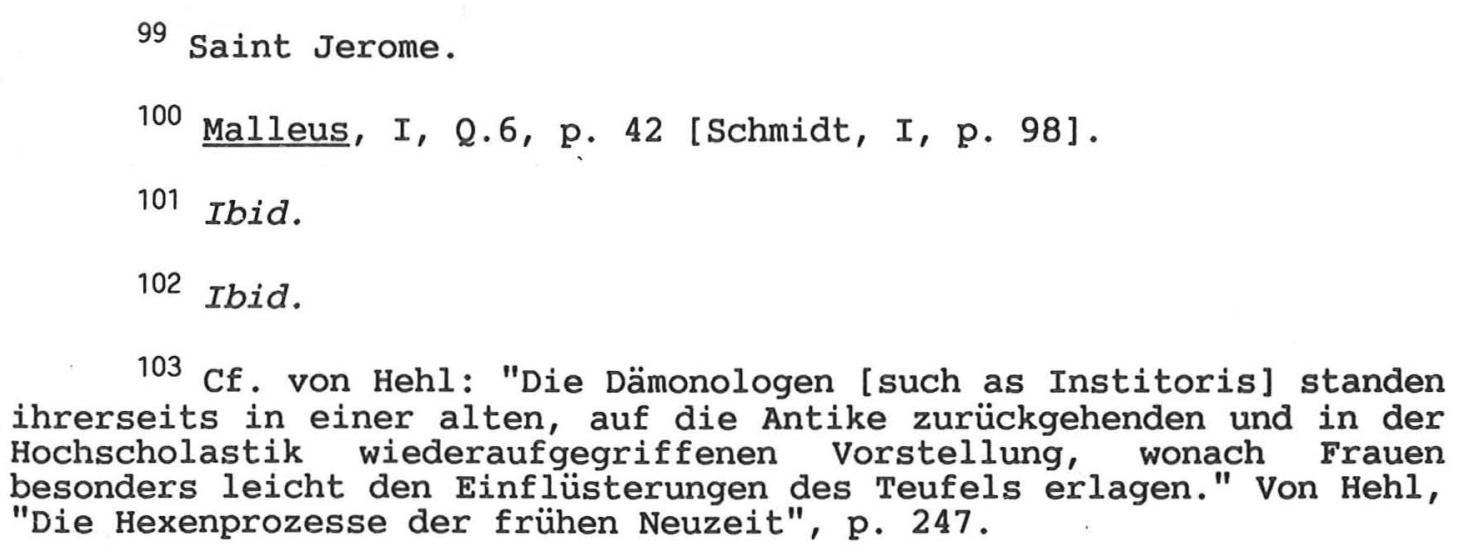


fluxibilitatem complexionis facilioris sunt impressionis ad revelationes capiendas per impressionem separartorum spirituum"104; and, that they are naturally inclined to gossip, enabling them to transmit to one another those occult secrets which allow them to compensate for their natural physical weaknesses - "quia lubricam habent linguam: et ea quae mala arte sciunt, eis comparibus foeminis vix celare possunt seque occulte, cum vires non habeant, per maleficia vindicare querunt facilites". All these reasons are subsumed under a more general consideration, the overall intellectual inferiority of women to men - "Quantum enim ad intellectum, seu ad intelligendum spiritulia alterius videntur ess speciei a viris cui auctoritas et ratio cum variis scripturae exemplis alludit". 105 Institoris then immediately proceeds to the argument which constitutes the second noteworthy feature of the text, that woman's limited capacity for intellectual development - tacitly equated with a greater sexual drive - is, in turn, directly dependant upon her inferior ontological status.

Ratio naturalis est, quia plus carnalis viro existit, ut putet in multis carnalibus spurcitiis: Qui etiam defectus notatur informatione primae mulieris, cum de costa carna formata fuit, id est, de costa pectoris, quae est torta, et quasi contraria viro. Ex quo defectu etiam procedit, quod cum sit animal imperfectum, semper decipit. 106

Institoris' attempts to substantiate this rather totalizing claim through the use

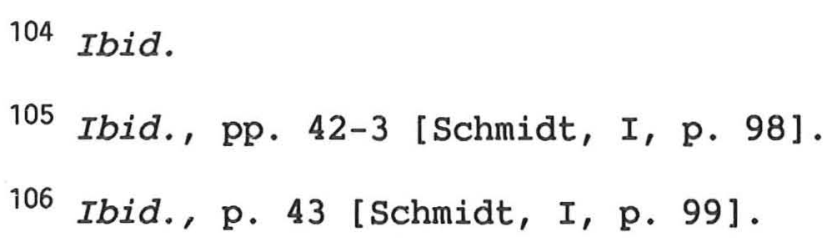


of a pseudo-etymological demonstration which has become justifiably (in)famous in both witchcraft and gender studies: the inherent metaphysical inferiority of women is said to be revealed through the conjunction of the Latin terms for both female and lack - "quae omnia etiam Etymologia nominis demonstrat. Dicitur enim Foemina a Fe, et minus: quia semper minorem habet et servat fidem: Et hoc ex natura, quoad fidelitatem." 107 As a result, Institoris feels confident enough to conclude:

Mala ergo mulier ex natura cum citius in fide dubitat, etiam citius fidem abnegat, quod est fundamentum in maleficis... Et quidem sicut ex primo defectu intelligentiae abnegationem fidei facilius incurrunt: ita ex secundo, scilicet inordinatis affectionibus et passionibus varias vindictas quaerunt, excogitant et infligunt, sive per Maleficas, sive aliis quibuscunque modis. Unde non mirum tantam multitudinem maleficarum in hoc genere existere. ${ }^{108}$

A closer examination of this chapter provides insights into some of the precise characteristics of the discursive strategies infusing the Malleus, particularly in regards to the ways in which the text attempts to incorporate the social reality of late medieval witchcraft practices into the confines of its pregiven scholastic demonological framework. This is particularly evident concerning the chapter's repeated references to the empirically given nature of the preponderance of women in malefic activities and accusations, an observation that is fully corroborated by the deposition records from Innsbruck.

Ibid. [Schmidt, I, p. 100].

108 Ibid., p. 44 [Schmidt, I, p. 102]. 
A crucial facet of the European Witch Hunt that is frequently underestimated by radical feminist critics who are consciously searching for objective manifestations of the patriarchal will-to-dominance ${ }^{109}$ is that the association between woman and witch far predates, and in no way originates with, the beginning of the production of witchcraft manuals in the early fif teenth century. In fact, the evidence is good that such an association dates from the classical era, the widespread belief in the Stria or Striga, a flying, cannibalistic female night witch with vampiric attributes evidenced by the Germanic Lex Salica of the sixth century. 110 Contemporaneous with such notions was the equally widely disseminated set of pre-Christian Germanic beliefs centered around Holda and her nocturnal train of followers, the protective domestic spirits known as "the ladies of the night". 111 As Norman Cohn has argued,

in both cases, we find that women are believed - and sometimes even believe themselves - to travel at night in a supernatural manner, endowed with supernatural powers by supernatural patrons. One belief is indeed the opposite of the other; with the cannibalistic witch, symbol of destruction, disorder and death, one can contrast the women who join the radiant 'ladies' on their benign missions for the encouragement of

109 See above, Introduction.

110 Cohn, Europe's Inner Demons, p. 208. The image of the Striga is frequently invoked in Silvester Prieria's treatise of 1520 . See above, Chapter Two.

111 For an Italian rendition of such beliefs see Ginzburg, The Night Battles, pp. 33-68; "The Witches' Sabbat", pp. 46-8. For the importance of such concepts with regards to the Canon Episcopi, see below, Chapter Five. 
hospitality and good housekeeping. 112

It appears that the early witchcraft treatises such as the Malleus, in establishing correlations between femaleness and witchcraft, were merely passively replicating widely held popular beliefs and concerns that had been formulated centuries beforehand. What requires explanation are not the testimonies of the witch hunters concerning the predominance of women in accusations of maleficium, but rather the reasons for the establishment of such a set of cultural notions on the popular level in the centuries antecedent to the professional witch hunters' efforts - such as (perhaps) female monopoly over herbalism - providing them with the means for occult aggression, or the close connections between rural fertility cults and shamanism ${ }^{113}$, a form of ecstatic religious activity frequently dominated by women. 114

It definitely appears as though feminist commentators ${ }^{115}$ were clearly mistaken in collapsing the distinction between origin and function when analyzing demonological texts by attributing to the authors a phallocentric

112 Ibid., p. 216.

113 Klaniczay, "Shamanistic Elements in Central European Witchcraft", pp. 404-22. "The general framework in which [the] interrogation and transformation of shamanistic beliefs take place is given by witchcraft beliefs." Ibid., p. 413. Cf. also Ginzburg, Hexensabbat, esp. chs. 2 and 3, pp. 153-223.

114 Lewis, Ecstatic Reliqion, pp. 26-7. Cf. also Ginzburg, Hexensabbat, ch. "Kämpfen in Ekstase", pp. 153-83.

115 see above, Introduction. 
intentionality that wilfully postulated a correlation between femininity and maleficium. What the demonologists do appear to have accomplished, however, is systematically to translate an essentially popular notion into the language of scholastic theological discourse - if the notion of woman as supernatural agent was widespread, the concept of "wise-woman" as satanist, a necessary corollary in the minds of the inquisitors, was not. An outstanding example of the way in which a professional demonologist such as Institoris could confuse and thereby subtly blend together the previously clearly distinct categories of witch, satanic heretic, and supernatural female, occurs in II, Q.1, c.7, p. 209 [Schmidt, II, p. 271] - that portion of the Malleus which is given over to a discussion of the various legally permissible means of countering witchcraft.

Error erat ut venientibus de nocte Daemonibus, aut ut vetulae dicunt Die Seeligen ${ }^{116}$, sed sunt Maleficae vel Daemones in earum effigiis, debent omnia consumere, ut post abundantius tribuant. Colorant quidam et dicunt, Schrettel.117 Sunt contra determinationem Doctorum, quod

116 A difficult word to identify: It seems to be related to "Seligen" ("Saligen"), Swabian for bestowing good luck upon a household - Schiller and Lübben, Mittelniederdeutsches Wörterbuch, Vol. 3, p. 16. Associated with Swabian Saligen, to bestow good luck or healing and the Niederrheinisch salich, also to bless with good luck - ibid., pp. 15-6. The nearest approximation is provided by Grimm, who identifies selig with "die saligen fräulein, die saligen, die freundlichen elbinnen des tirolischen volksglaubens"- Grimm, Deutsches wörterbuch, $x, 39 . \quad$ There is also an apparent relation to Seelenwandrung which may, within certain contexts, convey the notion of a soul that can disattach itself from the body and wander at will (although what is primarily intended is the quasi-romantic designation of the emotional yearning of the spiritual self), as well as Seelenwandlung which denotes a foreign soul capable of entering into bodies and effecting a qualitative change in the self - Ibid., p. 39.

117 Identified by Grimm as a wood-sprite or an elfin spirit Grimm, Deutsche Mythologie, III, pp.133, 138, 422. The word occurs in numerous forms: Schretel, a middle high German form located primarily 
praeter homines et angelos non sunt aliae creaturae rationales, unde non sunt nisi Daemones.

Employing the rigorous neo-Thomistic dialectic of the Realist scholastics which declares that all supernatural agency must out of necessity be of either demonic or angelic nature ${ }^{118}$, Institoris is driven to the inexorable conclusion that such entities must necessarily be of diabolic origins. This example brings our attention back to the second distinguishing feature of I, Q.6 of the Malleus, namely Kramer's scholastic rationalization of the preponderance of women in witchcraft accusations through reference to the metaphysical notion of woman's inferior and subordinate ontological status. Although the imagery employed may be scriptural, the underlying argument is thoroughly Aristotelian. The official academic notion of women remained fairly consistent throughout the fifteenth and sixteenth centuries ${ }^{119}$, a product of a cultural stasis resulting primarily from the desire to maintain the largely successful over-arching scholastic synthesis coupled with the more practical political needs of providing an

in the south-west and in the Oberpfalz, Kramer's main locus of activity. Significantly, it seems to be a Christian demonization of a pagan entity often associated with domestic functions and locales. During the late middle ages, Schretel appeared in numerous glossaries in connection with incubus, but this connotation disappeared in later periods - Handwörterbuch des Deutschen Aberqlaubens, VII, 1285-9.

118 See below, Chapter Five.

119 Maclean, The Renaissance Notion of Woman, p. 1. "In spite of the influence of neoplatonism... the scholastic infrastructure of the Renaissance notion of woman [remained] intact. This [was] due in no small part to the strong synthetic nature of the scholastic notion; no other system [was] evolved which [was] able to offer as comprehensive an explanation for the biblical commonplaces about woman." Ibid., p.25. 
intellectual justification of the institution of marriage. ${ }^{120}$ Both the physical and ethical facets of Aristotelianism were elaborately integrated with exegesis and systematic theology. Within the scholastic distinction between male and female

may be discerned Aristotle's general tendency to produce dualities in which one element is superior and the other inferior. The male principle in nature is associated with active, formative and perfected characteristics, while the female is passive, material and deprived, desiring the male in order to become complete.

This misogynistic polarity is particularly evident in Aristotelian physiology which views women as fundamentally passive, dominated by the moist humours, and unable actively to generate of fspring ${ }^{122}$, their menses being flawed semen deformed by their lack of body heat. 123 "Because of lack of heat in generation, her sexual organs have remained internal, she is incomplete, colder and moister in dominant humours, and unable to 'concoct' perfect semen from

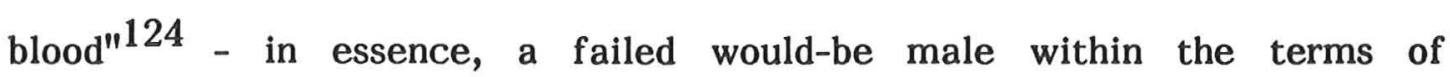
Aristotelian teleology, "a generative event not arrived through to its final conclusion", forever striving to attain its own completion through repeated

120 Ibid., p.82.

121 Ibid., p. 8 .

122 Ibid., p. 30 .

123 Lloyd, Polarity and Analogy, p. 59.

124 Maclean, The Renaissance Notion of Women, p. 31. 
sexual intercourse with the male. ${ }^{125}$ Seen within this context, the Malleus' seemingly arbitrary correlation between female intellectual inferiority and heightened carnal desires in relation to witchcraft becomes somewhat more intelligible. Woman's state of physical inferiority, signified by her more limited intellectual faculties, instinctively strives to compensate for itself through physical re-union with the teleologically more perfect form of man, this drive toward re-union/perfection manifesting itself through an enhanced sexual impulse resulting in a propensity towards licentious sexual behaviour which was, as we have already seen, a stereotypical characteristic of the satanic deviant.

As the examination of the trials at Ravensburg and Innsbruck clearly shows, the Malleus itself played a decisive role not only in reflecting and disseminating but also in actively reformulating perspectives on the nature and practice of witchcraft. ${ }^{126}$ The text was situated at a crucial nexus between various historical developments and agencies which not only determined its composition but which were, in turn, crucially affected by the discursive framework articulated by the text. Scholastic treatises such as the Malleus served as one

125

Ibid., p. 30 .

126 "Die berichteten magischen Praktiken, die angestrebten Ziele und die verwendeten Requisiten entsprachen offenbar dem realen Frauenalltag in einer mittelalterlichen Stadt. Ganz anders [ist dagegen] die Einordnung dieses Materials in das dämonologische Weltbild und in die inquisitorische Praxis des Institor." Dienst, "Magische Vorstellungen und Hexenverfolgungen", p. 78. 
component element among others, including governmental regulation ${ }^{127}$ as well as ecclesiastical investigation and surveillance ${ }^{128}$, within a more general network of power/knowledge. This network not only defined a (new) subject of disciplinary power in the act of identifying it, but it also produced a subsequent change in social policy and behaviour while in pursuit of the postulated object of concern. It was through simultaneously reflecting and affecting its own grounds of emergence that the Malleus was established as a vital textual lynchpin within the wider discursive apparatus mediating the workings of that array of juro-political complexes that underlay and regulated the very earliest origins of the European Witch Hunt.

127 See Heide Dienst on the example of Ferdinand III's Neue Peinliche Landqerichtsordnung: "Es is zu vermuten..., inwieweit diese Verordnung nicht nur eine Zunahme von Prozessen, sondern einen ganz spezifischen Inhalt von Geständnissen zur Folge hatte." Ibid., p. 73.

128 "Es liegt die Annahme nahe, daß die Inhalte [of popular demonology] sich durch predigt im Laufe der Jahrhunderte verändert haben." Ibid., p. 76. 


\section{CHAPTER FIVE:}

\section{THEOLOGICAL SOURCES AND TEXTS.}

Any discussion of the historical development of the demonological doctrine incorporated into the Malleus is facilitated by the remarkable intellectual constancy that exists between the two major figures in the development of the science, Augustine and Thomas Aquinas; they are also, not coincidentally, the two most frequently cited sources in the Malleus. ${ }^{1}$

Although medieval demonology by no means constituted a coherent body of doctrine, theoretical developments being subject to numerous contingent factors, the most crucial features of the science were already fully established in the late classical period. The reality of malefic magic, the satanic Pact, the illusory, nature of transformation of human into animal, the sexual activities of incubi and succubi, and the ability of demons to influence the local motion of bodies so as to produce effects like aerial transport and weather magic, may all be discerned in the writings of Augustine of Hippo. ${ }^{2}$ One is strongly inclined

1 See above, Chapter One. The works of Augustine explicitly referred to in the text are De Auquriis, De Civitate Dei, De Divinatione Demonum, De Doctrina Christiana, the Enchiridion, De Gratia et Libera Arbitrio, the Liber Soliloquiae, De Moribus Ecclesiae, De Natura Daemonis, De Spiritus and Book Two of De Trinitate; for Aquinas, the Second Book ("Secunda Sententiae") of the Commentum in quatuor libros Sententiarum Magistri Petri Lombardi, De Daemonibus, Summa Contra Gentiles, Summa Theologiae, De Virtute Daemonum, and the commentaries on Isaiah and Job.

2 Hopkin, The Share of Thomas Aquinas in the Growth of the Witchcraft Delusion, p. 177. Cf. also Russell: "The diabology of Augustine represented the general state of the concept as it existed in the mid-fifth century and the general lines of the development it would take in the future", Satan: The Early Christian Tradition, p. 
to concur with Charles Hopkin's argument that the

chief differences between scholastic demonology and that of the ancient sources is that the treatment has become systematic and theoretically rounded out, as a part of the scholastic ordering of all theology. While this systematizing did not produce within itself a unified witchcraft concept, it may indirectly have encouraged such a process in the courts of the Inquisition by setting up an atmosphere of logical integration. ${ }^{3}$

A more detailed comparison between the demonological pronouncements of Augustine and the later scholastics, notably Aquinas, highlights their striking degree of structural continuity. Indeed, the two doctors are at fundamental agreement on all essential issues of the demonic. There are altogether more than one hundred citations of Augustine within Aquinas' own demonological writings, including thirty-four from De Civitate Dei, twenty-five from the Super Genesis ad litteram, and fourteen from De Trinitate ${ }^{4}$ - next to

219.

3 Hopkin, The Share of Thomas Aquinas in the Growth of the Witchcraft Delusion, p. 177. Although Hopkin's study is tremendously valuable, one of its basic problems, implicitly argued against here, is his assertion that scholastic theologians, especially Aquinas, are not to be assigned primary responsibility for the origin of the "WitchCraze", supposedly because the Inquisition had in fact been persecuting suspects well before the development of the witch doctrine in the fifteenth century; scholasticism merely "provided the rationalistic explanation and 'proof' after the delusion had already been put into legal operation." Ibid., p. 182. Hopkin, however, omits any reference to the actual chronological development of witch-hunting, which reveals the highly marginal and largely sporadic rates of prosecutions of witches up to the time of the composition of the Malleus, the text described by Hopkin as containing "all the structural ideas of the witchcraft delusion in their fullest development and coordination, after which no essential additions were made." Ibid., p. 145. Hence, in opposition to Hopkin's own claims, the scholastic witch "paradigm" was in fact securely in place a full one hundred years before the truly large-scale persecutions commenced in the sixteenth century.

4 Ibid., p. 135. 
the Scriptures, Augustine is Aquinas' main authority on the nature of demonic activity. ${ }^{5}$ The only substantial point of difference between the two concerns the nature and reality of the sexual activity of incubi and succubi. Augustine addresses the issue in De Civitate Dei, Part II, Book 15, c. 23, when discussing the account provided in Genesis, c.6, 1-4, of the sons of God breeding with the daughters of men. Although Augustine concludes that the phrase "sons of God"

5 other prominent sources besides Augustine include Dionysus the Aeropagite in De Malo (Rome, 1965), Q. 16, art. 2, ad. 1,4 pp. 663; John of Damascus, in particular the second book of De Fide Orthodoxa, in De Malo, Q. 16, art. 1, sed contra 2 and 3, p. 657, Q. 16, art. 7, sed contra 1, p. 683; Gregory the Great, Moralia on the Book of Job, De Malo, Q. 16, art. 5, sed contra 2, pp. 675, and the Homilies on the Gospel, in De Malo, Q. 16, art. 10, pp. 693. Additional material is taken from the works of Ambrose, Jerome, Bede, Walatrid Strabo, Anselm of Canterbury, Hugo and Richard of St. Victor, and Peter Lombard. Cf . Hopkin, The Share of Thomas Aquinas in the Growth of the Witcheraft Delusion, pp. 139-43. As Hopkin rightly concludes, it is evident that Aquinas "did not have to invent any important structural elements of his demonology. Apart from its integration with the Aristotelian philosophy, he had only to lean upon the Biblical and ecclesiastical tradition", ibid., p. 144. Strikingly, virtually all of Aquinas' sources are reproduced within the Malleus - Dionysus the Aeropagite in: I, Q. 1, p. 1 [Schmidt, I, p. 2]; I, Q. 3, p. 20 [Schmidt, I, pp. 44, 45]; I, Q. 4, p. 26 [Schmidt, I, p. 59]; I, Q. 5, pp. 30, 32, 36 [Schmidt, I, pp. 69, 75, 82]; I, Q. 7, p. 48 [Schmidt, I, p. 111]; I, Q. 12, p. 70 [Schmidt, I, p. 162]; I, Q. 13, p. 74 [Schmidt, I, p. 171]; II, Q. 1 "Introductio", pp. 97, 100 [Schmidt, II, pp. 10, 17]; II, Q. 1, c. 4, p. 118 [Schmidt, II, p. 58]; John of Damascus, second book of De Fide Orthodoxa in: I, Q. 5, p. 31 [Schmidt, I, p. 72]; Gregory the Great, Moralia, in: I, Q. 2, p. 12 [Schmidt, I, p. 28]; III, Q. 19, p. 257 [Schmidt, III, p. 117]; Saint Ambrose in: $I, Q .1$, p. 8 [Schmidt, I, p. 17]; Saint Jerome in: I, Q. 5, p. 38 [Schmidt, I, p. 88]; I, Q. 6, pp. 41, 42, 44 [Schmidt, $I$, pp. 95, 98, 101, 103]; I, Q. 13, p. 76 [Schmidt, I, p. 178]; I, Q. 15, p. 83 [Schmidt, I, p. 194]; II, Q. 1, c. 11, p. 145 [Schmidt, II, p. 120]; II, Q.2, c. 2, p. 183 [Schmidt, II, p. 210]; II, Q. 2, c. 5, p. 192 [Schmidt, II, p. 232]; II, Q. 2, c. 6, p. 199 [Schmidt, II, p. 250]; II, Q. 2, c. 7, p. 204 [Schmidt, II, p. 261]; II, Q. 2, c. 8, p. 209 [Schmidt, II, p. 273]; III, "Introductio", p. 220 [Schmidt, III, p. 26]; III, Q. 19, p. 256 [Schmidt, III, p. 115]; Bede in: I, Q. 3, pp. 21, 22 [Schmidt, I, pp. 48, 49]; Walatrid Strabo in: I, Q. 1, p. 6 [Schmidt, I, p. 13]; I, Q. 3, p. 19 [Schmidt, I, p. 43]; Anselm of Canterbury in: I, Q. 17, pp. 87, 88 [Schmidt, I, pp. 203, 205]; Peter Lombard in: I, Q. 1, p. 3 [Schmidt, I, p. 6] . 
in fact refers to the children of Seth rather than to the physical of fspring of incorporeal demons, he also argues that the sheer quantity of accounts in classical sources concerning sexual pairing between humans and spirits renders it impossible to withhold credulity from the notion as such. ${ }^{6}$ Aquinas' own $^{\prime}$ self-imposed problem is somewhat different, concerned with explaining how human children could actually be born from such a union, given that demons can only fabricate artificial bodies for themselves. ${ }^{7}$

Certain influential doctrines which the two theologians propounded in common, such as the satanic Pact, as well as those which only Aquinas expounded, like the heretical nature of the Pact, shall be discussed below. At the moment it is more important to analyze the ways in which the diabology of the two saints addressed certain basic questions of theodicy. In turn, these attempts served certain common political functions which render intelligible crucial aspects of demonological thought. Present in both theologians is an impulse actively to avoid the dualistic metaphysical implications inherent within the notion of demonic agency and, by doing so, to undermine the intellectual pp. $172-7$.

6 Augustine, De Civitate Dei (London, 1924), II, Book 15, c.23,

7 This is accomplished by the supra-sexual demons acquiring live semen from men while in their succubi form and transmitting it to women in their incubi form. Aquinas, Summa Theoloqiae, I, Q. 51, art. 3, ad. 6 , p. 260. The Malleus reproduces the essence of this argument along with an extended discussion of demonic sexual activity in $I, Q .3$. There is also provided a detailed account of Augustine's argument from De Civitate Dei. 
legitimacy of (allegedly) dualistic heretical movements. ${ }^{8}$ It was the intellectual tensions arising from this doctrinal ambivalence internal to Christianity itself which served as the main impetus to theologians to construct a discourse linking dualist metaphysics with heretical dissent, a current most evidently pronounced in demonology, where the possibility of the ontological autonomy of evil has to be confronted most directly. 9

The intellectual interrelationships between Augustine's views on the nature of evil and the primacy of good, his demonological and anti-heretical pronouncements, and his own personal experiences with the struggles against Manichaeism, are excessively complex and do not need to be discussed here. ${ }^{10}$

${ }^{8}$ See Above, Chapter One.

9 To a great degree the theological consequences of a binary metaphysical system are implicit to a religion such as Christianity, and it is precisely this "unresolved conflict between monotheism and dualism [that] provides the central tension in the history of Christian diabology." Russell, Satan: The Early Cristian Tradition, p. 227. As Jeffrey Burton Russell has repeatedly argued, "Christianity is in fact a semidualist religion. On the one hand, it rejects the full dualism that asserts the opposition of the two cosmic principles. But it has also generally rejected the monist complacency of the hidden [cosmic] harmony." Russell, The Devil: Perceptions of Evil from Antiquity to Primitive Christianity, p. 228. Strong dualist or "semi-dualist" tendencies became thoroughly embedded within a number of that wide array of sects and cults which gradually coalesced to form what became early Christian doctrinal orthodoxy. As a result, the "perennial appearance of dualist views and dualist 'heresies' throughout the history of Christianity was not the intrusion of strange, external ideas, but rather the quelling of dualist views inherent in Christianity from the beginning." Russell, Satan: The Early Christian Tradition, pp. 160-1.

10 Cf. Brown, Auqustine of Hippo, ch. 5, pp. 46-60, passim; Deane, The Political and Social Ideas of St. Augustine, ch. 6, pp. 172220, passim; and Russell, Satan: The Early Christian Tradition, ch. 7, pp. 186-218, passim. G.L. Burr has called Augustine's philosophical engagement with dualism the "corner-stone" of scholastic theology. Burr, "The Literature of Witchcraft", p. 246. 
What is necessary for the purposes of the present study, however, is to illuminate how some of these concepts were reproduced in the later works of Aquinas and how they affected the development of late medieval demonology and, following from this, the Malleus. On the whole, Aquinas shared Augustine's views of the ontological negativity of evil, arguing that it is merely the deprivation of the good. ${ }^{11}$ Aquinas' most markedly evident discussion of this issue is contained within the Summa Contra Gentiles. In Article Sixteen of Chapter Seventy-one of Book One he declares that the existence of evil is established only through its ontological derivation from a previously existent good. 12 Chapter Seven of Part One of Book Three is dedicated to the proposition that evil does not in itself constitute an essence. ${ }^{13}$ From this it follows that good is, in fact, the cause of or, rather, the positive ontological substance from which evil is derived ${ }^{14}$ so that evil is in fact metaphysically based upon the good, deprived of any positive ontological being within its own

\footnotetext{
11 "The center of Aquinas' teaching on evil is privation", Russell, Lucifer: The Devil in the Middle Ages, p. 195.

12 "Quod malum non dicit esse nisi inquantum est privatio boni", Aquinas, Summe Contra Gentiles (Rome, 1961), I, c. 71, art. 16, p. 85.

13 Ibid., III, Part One, c. 7 "Quod Malum non est Aliqua Essentia", pp. 9-1; "Es his autem apparet quod nulla essentia est secundum se mala. Malum enim ut dictum est, nihil est aliud privatio eius quod quis natus est et debet habere: sic enim apud omnes est usus huius nominus malum. Privatio autem non est aliqua essentia, sed est negatio in substantia. Malum igitur non est aliqua essentia in rebus.", ibid., art. 1-2, p. 8 . $12-14$

14 Ibid., III, Part One, c. 10 "Quod Causu Mali est Bonum", pp.
} 
right. 15 Evil is thus situated within a universal context of ultimately benevolent providential design ${ }^{16}$ in which all things are inclined towards their teleological fulfilment in the imitation of God. ${ }^{17}$ As it is impossible for there to be a summum malum, Aquinas is able to conclude triumphantly in a revealing passage: "Per hoc autem excluditur error Manichaeorum, ponentium aliquod summum malum, quod est principium primum omnium malorum". 18

It is tempting to regard Aquinas' articulation of the problem of evil within the light of the political needs of the Church to construct a comprehensive ideological condemnation of metaphysical dualism, an objective rendered imperative by the political successes of the Cathars. ${ }^{19}$ The employment of anti-dualistic theology as a means of combatting heresy found frequent and powerful expression in Aquinas' demonological expositions. For example, in his commentry upon the Gospel of John in the Catena Aurea in Quatuor Evangelia, Aquinas declares

Absit ut diabolum principem mundi ita dictum existemus ut cum caeli et terrae dominari posse credamus sed mundus appellatur in malis hominibus, qui toto urbe terrarum diffusi sunt. Sic ergo dictum est, $14-15$

15 Ibid., III, Part One, e.11 "Quod Malum Fundatur in Bono", pp.

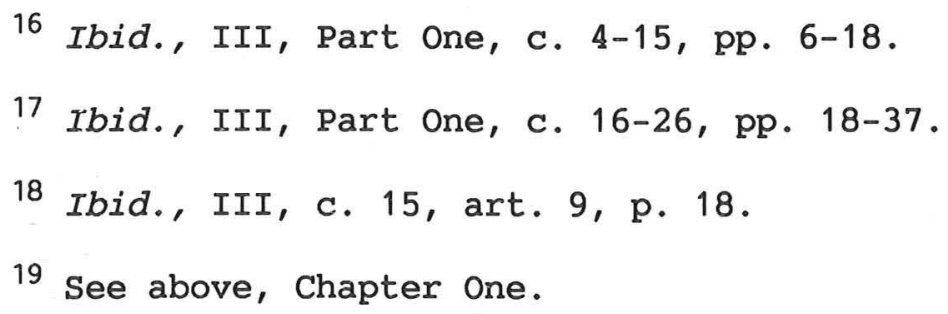


princeps huius mundi, id est princeps malorum hominum qui habitant in mundo. Appellatur etiam mundus in bonis, qui similiter per totum orbem terrarum diffusi sunt; ideo dicit Apostolus (2 Cor. 5, 19) "Deus erat in Christo, mundum reconcilians sibi". 20

Aquinas' theological language reveals the extent to which anti-heretical concerns permeate his engagement with metaphysical dualism. These more general concerns are repeated in his specialized demonological writings, indicating a discursive formation that attempts to identify demonism-dualism with the Manichaean-Heretic, thereby legitimizing the papacy's juro-political struggles with marginal and subversive religious groups.

As one would be led to expect, Aquinas denies the ontological primacy, or even autonomy, of demonic being, and argues instead, in a wholly selfconsistent fashion, that demonic nature is a secondary deprivation of primary

20 Aquinas, Catena Aurea in Quatuor Evangelia, Expositio in Ionnem (Rome, 1953), c. 12, art. 4, p. 498. Remarking upon this passage, Hopkin observes that "In the use of these terms, any Manichaean implications, which suppose the existence of an evil nature over against good nature, and a power to create on the part of the devil, are to be avoided. The devil rules over his subjects because he leads them to his end and because they initiate his sin. Some of his followers turn to his banner spontaneously, while others are induced to do so by suggestion of one kind or another. The kingdom is, nevertheless, powerful, not only because of the great power and wickedness of the demons, but also because the devil's human members act in so close and strong a union that no human virtue can separate them." Hopkin, The Share of Thomas Aquinas in the Growth of the Witchcraft Delusion, p. 59. The Malleus is absolutely adamant on the question of the witch's exercise of free will in the choice of evil, - Cf. I, Q.2, p. 13 [Schmidt, I, p. 29] "Quod sunt instrumenta animata et libere agentia, et licet post expressum pactum, initum cum Daemonibus non iam sint suae liberatis, quia ut ex earum fassionibus accepimus, et loquor de mulierculis combustis, ad plurima maleficia coactae, si verbera Daemonum subterfugere volunt, cooperantur, prima tamen professione, qua sponte se Daemonibus subiecerunt, manent ligatae." For a discussion of the significance of the Pact, see below, Chapter seven. 
angelic nature, i.e. demons exist only as a form of angel deprived of their original ministry to serve good and to enjoy the supernatural vision of beatitude. $^{21}$ Demonic function is held to follow demonic form, as Aquinas is compelled to argue against the potency of demonic supernatural activity, a necessary logical conclusion resulting from the demons' accidental (per accidens) metaphysical status. Since the natural virtues of demons vastly surpass the natural virtues of mortals because of their original angelic nature, they are able to perform numerous actions which appear miraculous to the unlearned, but which, in fact, are subject to the natural order of the universe. As a true miracle is that which transcends the natural order, and as God is the sole author of that order, all demonic - that is, non-providential - activity is a kind of natural action occurring on a higher level of understanding than that permitted to man but equally subject to divine permission. ${ }^{22}$ Employing neoAristotelian terminology, Aquinas concludes that power over bodily form, a substantial property, is the sole preserve of God who originally placed form(s) in potentiality towards accidental matter. As a result, demons, as higher agents, may only affect lower agents such as physical beings; they accomplish these accidental transformations through the proper employment of other natural agents.

21 Aquinas, De Malo, Q. 16, art. 1, sed contra 2, pp. 657.

22 Aquinas, Summa Contra Gentiles, III, c. 102-3, pp. 153-56; Summa Theologiae, I, Q. 110, art. 4, pp. 521-22. 
A theologis etiam contra dicitur quia formae corporales non sunt ex influentia demonum, sed ex influentia Dei, qui eas in potentia materiae posuit, et educere in actum potest sine adminiculo alicuius inferioris agentis, secundum quod in actum educuntur secundum cursum naturae ex determinatis agentibus naturalibus... Et ideo dicendum, quod daemones virtute propria nullam formam in materiam influere possunt, nec accidentalem nec substantialem; nec reducere eam in actum, nisi adminiculo proprii agentis naturalis: sicut enim artifex non propria virtute, sed virtute ignis oppositi calef acit; ita daemones ad determinatu passiva possunt coniungere activa, ut sequatur effectus ex causis quidem naturalibus, sed praeter conseutum cursum naturae, propter multitudinem et vehementiam virtutis activae rerum aggregatarum, et propter habilitatem passivorum: et ideo effectus qui non sunt in potestate alicuius virtutis activae naturalis, producere non possunt, ut suscitare nortuum, vel aliquid huiusmodi, secundum veritatem, sed in praestigiis tantum, ut infra dicetur. 23

Restrictions in potency derived from inferior ontological status determine the whole field of demonic action, even including alleged diabolic transformations of humans into animal forms, one of the most widespread of popular beliefs concerning maleficium ${ }^{24}$ - as it is clearly impossible to reconcile two opposing forms within a single substance, the subjective experience of alteration in form is the result of demonic influence over the natural bodily humours causing false perception: in short, a form of diabolically induced hallucination. 25

23 Aquinas, Sententiarum (Venice, 1586), II, D. VII, Q. 3, art. 1, sed contra 1, fols. 24v-26r. Cf. Hopkin, The Share of Thomas Aquinas in the Growth of the Witchraft Delusion, p. 120.

24 Cf. Baroja, World of Witches, pp. 36-8; Senn, Were-Wolf and Vampire in Romania, pp. 10-11.

25 Aquinas, Summa Theologiae, I, Q. 111, art. 3, pp. 524-5. 
Aquinas' basic strategy should by now be clearly discernible. It is a logical necessity for him rigorously to argue the non-miraculous status of demonic agency so as to subordinate malefic events to providential omnipotence, thereby circumventing the possibility of a dualistic metaphysical order while simultaneously undermining the philosophical legitimacy of Manichaean - i.e. Catharist - heresy. Within theo-political terms, Aquinas' strategy performs a double function. On the one hand, it implicitly links dualist heretical belief with demonic activities while at the same time discrediting the validity of such belief. On the other hand, such demonic activities, with their implied dualist cosmology, are rendered intellectually intelligible - and, by extension, politically controllable - within an orthodox Catholic theological and philosophical framework.

Such concerns and stratagems are inscribed within the basic premises of the Malleus. It is essential for Institoris' purposes not only indisputably to the physical reality of maleficium but also to demonstrate its inherently satanic nature through a necessary linkage between witch and demon while, at the same time, subjugating the actions of both to providential will. Hence, the text's famous declaration of the three necessary preconditions of witchcraft, i.e. the witch, the Devil, and God: 
Deinde magis in spirituali tenore Bullae Apostolicae ${ }^{26}$ in haerendum considerandum est de origine Maleficorum [sic], et eorum operum multiplicatione, et primo de ipsis Maleficis, secundo de eorum operibus. Ubi notandum, quod quia ad huiusmodi effectum tria habent concurrere, scilicet Daemon, Maleficia, et divina permissio... Si per Sortiarias Augustinus etiam dicit, quod ex pestifera societate hominum et daemonum haec superstitiosa vanitas adinuenta. Id eo origo et multiplicatio huius Haeresis ex pesti fera hac societate sumitur, quod etiam ex aliis elicitur. ${ }^{27}$

The preliminary question of the text is entitled "Utrum asserere maleficas esse, sit adeo Catholicum, quod eius oppositum pertinaciter asserere omnino sit haereticum?" Institoris advances this opinion by arguing strenuously against the contrary proposition as articulated by the Canon Episcopi regarding

26 Yet another example of Kramer's expedient usage of the authority of the papal Summis as a means of legitimizing his antiheretical activities, in this case abstract theological argumentation. A similar stratagem occurs later on in the same question which seeks to establish the authority not only of the papal curia but the entire intellectual and theological tradition of the Church as a whole. "Cui tamen heu obstat et Apostolicae Sedis per Bullam determinatio, verum et experientia rerum magistra, que nos ex propriis eorum fassionibus ac flagitiis perpetratis in tantum cerrificauit, quod absque disppendio propriae salutis iam ab eorum inquisitionibus desistere nequimus. Ideo de eorum prigine diligentia singula sunt perscrutanda quod et admittenda, quae rationi consona et Scripturarum traditionibus non dissona inueniuntur", Malleus, I. Q.2, p. 18 [Schmidt, I, p. 39]. An additional reference is "Nam omnia mala in bonis maturae et formae procurare possunt, Deo permittente, ut ex Bulla Papae deducitur.", I, Q. 14, p. 77 [Schmidt, I, p. 179].

27 Malleus, I, Q.2, p. 17 [Schmidt, I, p. 38]. Cf. I, Q.11, p. 68 [Schmidt, I, p. 159], "Tria necessarrio ad maleficialem effectum concurrere. Daemonum cum maleficia et diviniam permissionem." Nowhere are the basic truth claims of these three conditions placed in doubt. Rather, the basic purpose of the text is to provide an intellectual rationalization consistent with basic demonological principles concerning the existence and operation of witchcraft - a goal undoubtedly at one with Kramer's own allegedly personal encounters with the objective reality of maleficia while an active inguisitor in Germany from 1482-6. See above, Chapter Three. 
the illusory nature of malefic phenomena. ${ }^{28}$ The greater part of Institoris' initial argument is taken up with a standardized appeal to scriptural authority. 29 In a similar fashion, Institoris summarily dismisses the opinions of those who declare that the alleged sightings of demons are hallucinations. 30 The text then immediately proceeds to press the striking claim that "Quia vero infedilitas in baptizato, haeresis nominatur; ideo tales de haeresi reprehenduntur." 31

At this point, Institoris elaborates his critique of the scepticism inherent within the Canon by widening his field of authoritative sources, ecclesiastical and secular as well as divine. His list of sources is truly impressive - the Summa Contra Gentiles, Part One, Question 114, Argument Four, and Book Three, Chapters One and Two; the "Secunda Secundae" of the Summa Theologiae, Questions Ninety-two and Ninety-four; De Civitate Dei, Part Two,

28 Malleus, I, Q.1, passim [Schmidt, I, pp. 1-20]. For the role played by the Canon in the Malleus, see below, Chapter Six.

29 "Illam opinionem esse ominino contra auctoritates sanctorum, et procedere ex radice infidelitatis. Quia auctoritas Scripturae sacrae dicit quod daemones habent potestam supra corporalia et supra imaginationem hominum, quando a Deo permituntur, ut ex multis Scripturae sacrae locis notatum." Malleus, I, Q.1, p. 2 [Schmidt, I, p. 4].

30 "Et quum haec vera fides repudiat, per quam angelos de coelo cedidisse, et daemones esse credimus ideo et fatemur ipsos ex subtilitate naturae suae multa posse, quae nos non possumus. Et illi qui eos ad talia indicut, facienda, maleficia vocantur, haec ibi." Ibid. [Schmidt, I, p. 4].

31 Ibid. [Schmidt, I, p.4]. For further discussions of the implications of this passage, see below. 
Book Eighteen, Chapter Seventeen; De Doctrina Christiana, Book Two, as well as the entire body of commentary and exegesis upon the account of Pharaohs' magicians provided in Exodus VII. All this enables Institoris confidently to conclude that "Eorum scripta inspiciuntur et cuius cumque doctoris super 2. liber. sent. inuenis, nullo discrepante, magos et maleficas virtute daemonum permittente Deo, miros effectus non phantasticos posse producere." Having thus in his own mind clearly established the objective - or, at least, the nonillusory - nature of demonic occumences, Institoris is now free to postulate a necessary correlation between witchcraft and satanic intervention.

Nec valet, si dicutur, quod etiam phantasia sit quid reale, quia sicut phantasia ut talis, nil potest essicere nec concurrere ad daemonis operationem nisi per pactum initum cum daemone, in quo pacto malefica se totam obtulit et astrinxit Diabolo vere et realiter et non phantastice aut imaginarie solum: ita etiam oportet quod cooperetur Diabolo vere corporaliter. Nam et ad hoc sunt omnia maleficorum opera, ubi semper aut per visum aut per locutionem alicuius malefici instrumenti repositi sub limine domus operatione sua maleficia exercent. 32

The strident tone of this declaration concerning the efficacy of satanic operation, however, places upon Institoris the responsibility of having to situate the reality of demonic power within a context suitable to the precepts of Catholic theology. The text seeks to accomplish this by advancing two basic lines of argumentation. The first is to demonstrate providential omnipotence by postulating divine permission as a necessary precondition for maleficium.

32 Ibid., I, Q.1, pp. 5-6 [Schmidt, I, pp. 11-12]. 
The second, which is in accordance with the Augustinian and Aquinian notion of evil, is to relegate maleficium to an inferior ontological status by denying its capacity to affect authentic (meta)physical transformation. Each will now be examined in turn.

Providential control over demonic activity becomes a theme repeatedly alluded to in the text. Although asserted in a rather arbitrary fashion in I, Q. 1, as has already been noted, the whole of I, Q. 12 [Schmidt, I, pp. 159-71] is devoted to the problem "An Dei permisso concurret ad Maleficia". Institoris confronts this potentially subversive question with a candor unparalleled anywhere else in the Malleus. He first proceeds by forcefully advancing the proposition which is intended to be ultimately rejected, namely "an divinam permissionem in his operibus maleficorum [sic] commendare ita sit Catholicum, quod eius oppositum, scilicet redarguere illam, omino sit haereticum." Institoris proceeds to formulate the argument as follows.

Et arguitur, quod non sit haereticum asserere, quod Deus tantum potestatem non permittat diabolo in huiusmodi maleficiis. Refutare enim illa, quae in contumeliam creatoris possunt cedere, est Catholicum et non Hereticum. Sed asserere, quod diabolo non permittatur talis potestas nocendi hominibus, est Catholicum. Probatur, quia oppositum asserere, videtur cedere in contumeliam creatoris. Non sequeretur quod non omnia sunt subiectu divinae providentiae, eo quod omnis sapiens provisor excludit defectum et malum, quantum potest ab his quorum curam gerit: Cum autem ea, quae per maleficia siunt, si a Deo permittuntur, ab eo non excluduntur: et si ab eo non excluduntur, non erit sapiens provisor ipse Deus, et sic non subsunt omnia suae providentiae, quod quia falsum est, 
ideo hoc falsum quod Deus permittat. ${ }^{33}$

Institoris goes on to elucidate various other objections which could be expressed in a similar manner: God's concern equally to protect all men from evil, the fact that God alone is the source of all that is good and therefore logically cannot actively sanction an evil like witchcraft, and the seeming arbitrariness of bewitchment, neither the frequency nor the severity of which can be correlated to the objective degree of the sinfulness of the victim. ${ }^{34}$

As the author openly declares in his responsio, "Quaestio quanto utilior ad praedicandum tanto etiam difficilior ad intelligendum existit." Thanks to the learned (sapientum) who remain ignorant about the necessity of divine permission, "Maleficiae non supprimuntur per ultionem debitam, iam totam Christianitatem depopulare videntur." ${ }^{35}$ The crux of Institoris' response is to stress the all-encompassing nature of the providential will in such a way as to render malefic occurrences subject to and dependent upon divine intent in a fashion that is almost axiomatic ${ }^{36}$, backed by an appeal ${ }^{37}$ to the

Ibid., I, Q. 12, p. 69 [Schmidt, I, p. 160].

34 Ibid., I, Q. 12, pp. 68-73 [Schmidt, I, pp. 159-71].

35 Ibid., I, Q. 12, p. 70 [Schmidt, I, p. 163]. A possible reference to Kramer's failure to obtain convictions at Innsbruck. See above, Chapter Three.

36 "Omnia divinae providentiae subiucere, non in universali tantum, sed in particulari, quod non solum maleficio hominum, sed et iumentorum, et terrae frugum, ex Divina et provida permissione eveniunt. Quod sic patet. Ad tantum se extendit providentia et ordinatio rerum in sinem, quantum ipsa causalitas se extendit: Sicut a simili in rebus alicuius dominio subiectis, quae in tantum subiacent 
unassailable scriptural authority of St. Paul. Such metaphysical pronouncements concerning Pauline theology are, of course, clearly insufficient in answering the brutal existential implications of the moral issue at stake, as Institoris himself confesses.

Sed quia per hoc non satisfit, ut intelligatur, quod Deus iuste permittat mala sieri, et maleficia in mundo, licet intelligamus hoc, quod ipse sit provisor, omnia gubernans, quod quia conceditur, ideo etiam debert omne malum ab his quorum curum gerit, excludere. 38

It is at this crucial point that the text puts forward an argument that is essentially Augustinian: that Providence's allowance of evil and sin - and, by implication, of witchcraft - is necessary to the transformation of the world into a higher state of good. "Deus permittit, licet non velit malum fieri, et hoc propter perfectionem universi... Erit malum ad omnes, id est, perfectionem universi conferens." 39 Expanding upon the principle of divine omnipotence, Institoris is able to argue

eius providentiae, in quantum sibi existunt subiectae. Cum autem causalitas Dei, quae est primum agens, extendit se adomina entia, non solum quantum ad principia speciei, sed etiam quantum ad principia individualia, et non solum incorruptibiliam. Ideo sicut omnia habent esse a Deo, ita omnia sunt provisa $a b$ eo, id est, ad aliquem finem ordinata." Ibid., I, Q. 12, p. 71 [Schmidt, I, p. 165].

37 "Et hoc tangit Apostolus ad Rom. 13: quasi dicat, sicat omnia a Deo sunt, et per consequens providentiae eius subiectu. Quia providentia Dei nihil aliud noscitur, quam ratio, id est, causa ordinis rerum in finem. Omnia ergo in quantum participiunt deesse, in tantum etiam subduntur Divinae providentiae." Ibid., I, Q. 12, p. 71 [Schmidt, I, p. 165].

$$
\begin{aligned}
& 38 \text { Ibid., I, Q. 12, p. } 71 \text { [Schmidt, I, p. 166]. } \\
& 39 \text { Ibid., I, Q. 12, p. } 70 \text { [Schmidt, I, p. 162]. }
\end{aligned}
$$


Deus [...] cum sit universalis provisor totius mundi et potest ex particularibus malis plurima bona eclicere, sicut persecutione Tyrannorum patientiam martyrum, et ex geribus maleficorum [sic]purgationem seu probationem fidei instorum, ut patebit. ${ }^{40}$ Ideo non habent Deus omnia mala impedire, ne multa bona deesse contingat universo. ${ }^{41}$

Extended discussions of the various ways in which such good may be brought about occupy a substantial portion of the remainder of Part One of the Malleus.

I, Q. 13 "Declarantur quaestio super duas permissiones Divinas, quas Deus iuste permisit, videlicet, Diabolum auctorem omnis mali peccare, simul et primos parentes cadere ex quibus Maleficorum opera iuste permittuntur" [Schmidt, I, pp. 171-8] illustrates the ways in which the entry of sin into the world through the Fall(s) of both Lucifer and Man is concordant with the benevolent designs of Providence ${ }^{42}$ - particularly in so far as both events are dependent upon the

40 In I, Q. 15, pp. 83-4 [Schmidt, I, pp. 193-4], the text provides a detailed discussion of the various ways in which divine permission of human suffering produces benevolent results - the glorification of God, the acquisition of merit through the practice of patience in the face of suffering, the acquisition of virtue through degradation, the salutory demonstration of the pain of eternal damnation, and the correction and possible expurgation of sin. The passage concludes with a typically Augustinian sentiment: "Posset etiam dici, omnem poenam quam patimur procedere ex culpa nostra, saltem originali, cum qua nascimur, quia ipsa est causa omnium causalitatum."

41 Ibid., I, Q. 12, pp. 71-2 [Schmidt, I, p. 166].

42 "Sicut enim ad eundem finem homo et Angelus creati fuerunt, et in libertate arbitrii relicti: propterea ut beautitudinis praemium non absque merito perciperent. Ideo sicut Angelus a casu non fuit praeservatus, ut potestas peccandi ex uno, et potestas gratiae confirmationis ex alerto ad decorem universi patesceret, ita et circa hominem servaru oportuit", ibid., I. Q. 13, p. 75 [Schmidt, I, p. 174]. 
exercise of free will. ${ }^{43}$ Q. 18 , in turn, provides a list of instructions to preachers to be followed in combatting popular disbelief in the reality of divine permission in the occurrence of maleficia. ${ }^{44}$ There is little that is original in these passages, the arguments consisting of not much more than the regurgitation of established authorities. What is of interest is rather the strategic way in which they are deployed, the text engaged in a systematic exegesis of the basic tenets of Catholic theodicy in order to nullify any attempt to derive dualist and thereby heretical conclusions from the widespread reality

43 The author's adherence to the Catholic doctrine of the freedom of will results in an equally powerful opposition to the notion of fatalism. "Ubi notandum, quod Fatum ess aliquod uni modo Catholice assentur. Alio modo asserere, est omnino haereticum. Si entim Fatum aestimetur esse secundum aestimationem quorundam Gentilium, et quorundam Mathematicorum, qui putabant, quod ex vi positionis sy derum causaretur infallibiliter diversitas vorum [...] Et istam vim vocaverunt nomine Fati.

Sed quia ista opinio non tantum est falsa, imo haeretica et omnino detestandia propter inconvenientia quae necessaro sequerentur, ut supra tactum est circa reprobationem primi erroris, quia videlicet tolleretur ratio mariti et demeriti, imo gratiae et gloriae, et quod Deus malorum nostrorum auctor esset et plura alia. Ideo Fatum sic omnino refutatur, quia nihil est". Ibid., I, Q. 5, p. 33 [Schmidt, I, p. 76].

44 "Super tertium principale primae partis tractatus, et proponantur illa quae sunt magis ad populam quomodo videlicet Deus permittit mala fieri, licet non velit malum fieri, permittit autem propter admirabilem perfectionem universi, quae confideratur in hoc, quod bona commendantur eminentius et magis placent, et sunt laudabiliora, dum comparatur malis: habetur ibi auctoritates. Item, profunda Dei divinae sapientiae, iustitiae et bonitatis relucent, quae alias essent occulta [...] hoc utique congruit divinae sapientiae, quae cum rebus omnibus sic administrat, ut eas propriis motibus agere finat. Ideo sicut non conuenit malitiam Daemonis omnino impedire, sed potius decet ipsam permittere, ut agat quantum ad bonum universi non tantum noceat, quantum nocere vellet. Ita etiam non convenit malitiam humanum refrenare super ea, ad quae ex libertate arbitrii potest, ut est fidem abnegare, et seipsum Daemoni devovere, quae utique facere in potestate sunt voluntatis humanae. Ex quibus etiam duobus, cum Deus maxime offenditur, iuste permitti ea ad quae Diaboli potentia se extendit, ut est hominibus iumentis, et terrae frugibus posse nocere", ibid., I, $Q$. 18, p. 90 [Schmidt, I, pp. 208-9]. 
of witchcraft.

The second argument utilized in the text - the transformative inef ficacy of maleficium - is particularly evident in I, Q.10, "An maleficia operuntur circa homines, in bestiales formas praestigios arte illos transmutando". This question reproduces the neo-Aristotelian essentials of Aquinas' argument in the $\underline{\text { Sententiarum }}^{45}$ and serves as a sed contra to the pronouncements of the Canon Episcopi concerning the illusory nature of demonic transformation. ${ }^{46}$ After insisting upon proceeding in a properly scholastic fashion ${ }^{47}$, Institoris rapidly comes to the Aquinian conclusion that demonic transformations are not truly miraculous because they are fully subject to the natural laws of the

${ }^{45}$ Cf. Aquinas, Sententiarum, II, D. 8, fols. $26 r-28 v$.

46 "Quarto ipsa veritas declaratur: vel etiam homines transformant in bestias, quod qualiter fiat, arguitur quod non sit possibile hoc fieri. 29 [sic]. q. 5. Episcopi ex concilio Acquirensi. Quisquis credit posse fieri aliquam creaturam, aut in melius, aut deterius immutari, aut transformari in aliam speciem vel in aliam simultitudinem, nisi ab ipso creatore qui omnia fecit, et per quem omnia facta sunt, proculdubio infidelis est et pagano deterior", Malleus, I, Q. 10, p. 63 [Schmidt, I, pp. 145-6]. The Canon is referred to a second time later on in the same question: "Patet et ex hoc Canone, 26, q. 5. Episcopi. Illud non est omittendum, quod quaedam sceleratae mulieries post Satan retro conversae, Daemonum illusionibus et phantasmatibus seductae, credunt se et profitentur, cum Diana horis nocturnis Dea paganorum, vel cum Herdiade, et cum innumera mulierum multitudine equitare, super quaesdam bestias, et multa terrarum Spatia, intempestae noctis silentio pertransire: et infra. Quapropter sacerdote praedicare debent populo Dei, ut noverit omnino haec falsa esse, et non a Divino, sed a maligno spiritualia phantasmata mentibus fidelium irrogari. Siquidem ipse Satanas transformat se in diversarum personarum species atque similitudines, et mentem, quam capitivam tenet in somnis deludendo per devia quaeque deducit." Ibid., I, Q. 10, p. 64 [Schmidt, I, p. 149].

47 "Ad praesens tantammodo scholastice procedendo, dicamus trium Doctroum sententias concordantes, in eo quod Diabolus potest phantasiam hominis decipere, ut homo vere animal videatur." Ibid., I, Q. 10, p. 64 [Schmidt, I, p. 148]. 
universe. The supposed transformations are achieved by demons exercising their natural virtue derived from their original angelic status. ${ }^{48}$ Unlike, God, Satan is unable to produce substantial transmutations such as those implied in reports of humans being changed into animals, but he is capable of inducing changes in the accidental properties of physical bodies.

Super secundum ubi tangitur, quod non possunt aliquam creaturam transmutare. Dicas quod est duplex transmutatio, substantialis et accidentalis: et haec accidentalis, iterum duplex, quia per formam naturalem et inhaerentum rei quae videtur, vel per formam non inhaerentem rei, quae videtur, sed inhaerentem organis et potentiis ipsius videntis. De primis loquitur Canon, et praecipae de formali deu quidditiua transmutatione, prout una substantia in aliam transmutatur, cuius modi solus Deus quid talium quidditatum creator existit, facere potest. Loquitur etiam et de secunda, licet illam Daemon efficere possit, in quantum per infirmitates divina permissione immissas, aliqua forma accidentali corpori inducitur. Ut ubi leprosa facies appareret vel huius simile. ${ }^{49}$

Although given province over accidental properties, Satan is only able to instill

a false belief in the reality of substantial, or formal, change by means of his

48 "Corpora naturaliter subduntur et obediunt naturae Angelicae quantum ad motum scalem. Angeli autem mali, etiamsi amiserunt gratiam, non tamen virtutem naturalem, ut sapiens supra tactum est. Cum autem potentia phantastica, sine imaginatina sit corporalis, id est, affixa organo corporeo, naturaliter subditur etaim malis, ut possint eam transmutare, causando varias phantasias ex descensione humorum, et spirituum, ad principium sensituum procurata ab eis." Ibid., I, Q. 10, p. 64 [Schmidt, I, pp. 148-9].

49 Malleus, II, Q. 1, c. 8, p. 132 [Schmidt, II, pp. 89-90]. Institoris substitutes his claim by analyzing the classical accounts of bestial shape-shifting in the myths of Ulysses and Diomedes. The question of the transformation of human into animal via the medium of maleficia is discussed for a final time in II, Q. 2, c. 4 [Schmidt, II, pp. 219-23], "De remediis, cum praestigiosa arte membra virilia auserunter, et cum homines in bestiales formas transmutantur", where Institoris discusses the permissibility of the various ways of countering such bewitchment; see below, Chapter Six. 
power over the material properties of sense perception: "Potest igitur Diabolus, per commotionem interiorum spirituum et humorum, operari ad immutandum actum et potentiam, nutriativae, sensitivae et appetitivae, et cuiuscumque potentiae corporalis organo utentis." ${ }^{\text {50 }}$ II, Q. 1, c. 9, p. 134 [Schmidt, II, pp. 94-5] provides more detail on the actual mechanics of the inducement of demonic delusion:

Item, licet illabi animae illi sit tantum possibile, qui eam creavit, tamen Daemones etiam illabi possunt, Deo permittente, corporibus nostris. Et quiu pro tunc possunt impressiones facere in potentias interiores affixas organis corporalibus. Ideo et per illas impressiones, sicut immatantur organa, ita immutantur operationes potentiarum modo quo dictum est: quod educere possunt species reservatus in una potentia affixa organo: sicut ex memoria, quae est in ultima parte capitis, educit speciem equiilocaliter movendo illud phantasma usque ad mediam partem capitis, ubi est cellula virtutis imaginativae: et demum consequentur usque ad sensum communem cuius residentia est in anteriori parte capitis. Et omnia subito sic immutare et perturbare possunt, ut formae tales necessario aestimentur, ac si exteriori visui obiicerentur: Exemplum patuit ex naturali defectu in Phreneticis et aliis maniacis.

As a result, demonic effects are simultaneously real and illusory: real, because accidental properties can be affected and because the false notion of formal transformation can be implanted within the mind of the perceiver, and illusory, because the alleged substantial change is not an objective external phenomenon but only a subjectively imagined one. Through a series of interlocking argument and references, the general contours of which are by now clear, Institoris is able dogmatically to assert that demonic agency cannot be truly

50 Malleus, I, Q. 10, p. 65 [Schmidt, I, p. 150]. 
miraculous - and, therefore, also not divine - because its field of operation is by logical and metaphysical necessity restricted to the accidental realm.

Ad illud tantammodo; An temporalia opera maleficorum [sic] et Daemonum sint ad modum miraculosorum operum censenda: ita quod debeant opera miraculosa aestimari. Dicendum, quod sic, in quantum siunt praeter ordinem naturae creature nobis notae per creaturam nobis ignotam: licet non sint proprie miraculosa sicut illa, quae siunt praeter ordinem totius naturae creaturae qualia sunt miracula Dei et sanctorum. 51

But this very admission of the, albeit restricted, reality of demonic phenomena compels Institoris to provide his readers with the means of distinguishing between providential and diabolic occurrences. ${ }^{52}$ Slightly more detailed provisions on this issue are provided at a later point in the question. They touch upon the length of the duration of the miraculous event, true miracles lasting longer;the utility of the event, divine miracles always producing practical results; and the role performed by the miracle in edifying and strengthening the Faith. The fourth condition, seemingly added as an afterthought, is, "Etiam quantum ad modum operandi differunt, quia boni operantur mirabilia per invocationem divini nominis pie et reverenter. Sed malefici et mali quibusdam deliramentis, et Daemonum invocationibus." On the basis of these criteria, the

51 Ibid., II, Q. 1, c. 9, p. 135 [Schmidt, II, pp. 96-7].

52 "Cum miraculum proprie quatuor requirat, scilicet quod sit a Deo, et quod sit prater existentiam naturae, contra cuius ordinem sit: et tertio quod sit evidens: et quarto quod ad fidei corroborationem: quia origo in operibus maleficarum quoad primum et ultimum ad minus deficiunt, ideo mira opera, non autem miracula dici possunt." Ibid., II, Q. 1, c. 9, p. 136 [Schmidt, II, p. 99]. 
Malleus is able to support the contention of the apostles that the apparent miracles performed by the Antichrist are indeed "signa mendacia".

quia tunc mirabilia, quae sunt ab eo divina permissione sunt vera, et etiam falsa diversis respectibus. Vera in illis, quae siunt virtute. Daemonis ad quae eius virtus se extendere potest. Falsa, quando faciet ea ad quae sua virtus se non potest extendere, ut suscitare mortuos, illuminare caecos. Quia in primo, ubi facere attentabit, aut intrabit corpus defuncti, aut illud amovebit, et loco illius ipse in assumpto corpore ex aere se praesentabit, et sic in secundo praestigiosa arte visum ausert, aut infirmitates alias et subito sanabit a laesione cessando, non qualitates interiores testis; cando, sicut in legendo Bartholomaei ponitur. ${ }^{53}$

Consequently, as it is with the Devil and his demons, so it is with his primary

agent in the secular world, the witch.

Quia esti aliquo modo miracula dici possunt, quia tamen quaedum sunt supra naturam, quaedam contra naturam, quaedum praeter naturam. Et supra naturam sunt illa, in quibus non est simile in natura nec eius potentia, ut virginem parere. Contra naturam, ut quae siunt usu contrario naturae: terminatur autem ad conformae naturae, ut caeci illuminatio. Et praeter naturam, ut quae siunt ordine simili naturae, ut in mutatione virgorum in serpentes, quod natura facere potuisset per longam putrefactionem propter rationes seminales, sic etiam opera Magorum diecentur mirabilia. 54

Whatever the form of demonic action, whether material or psychological, accidental of illusory, the potential threat posed by any dualist subversion is undermined through the subordination of all diabolic ploys to the providential design: "Sed nihil horum potest Diabolus facere, nisi Deo permittente, qui cum

53 Ibid., II, Q. 1, c. 9, p. 136 [Schmidt, II, p. 98]. Cf. Emmerson, Antichrist in the Middle Ages, $\mathrm{ch}$. 4, on various medieval accounts of the false miracles performed by the Antichrist in order to acquire power.

54 Malleus, II, Q. 1, c. 9, p. 136 [Schmidt, II, p. 99]. 
Angelis suis bonis frequenter reprimit malitiam eius, decipere nos et nocere quaerentis." 55

Several key features of the general discursive framework of the text have now been clearly established. Through the incorporation of certain basic features of the neo-Aristotelian scholastic discourse of Aquinas, the Malleus establishes a complex network of interconnecting references between the related subjects of dualism-demonism and Heretic-Witch. The politically suspect object, the Heretic-Witch, is situated within a total discursive apparatus that identifies and classifies the subject's perceived transgressions through a series of mediating ideological devices which, by that very process, render the subject both intelligible (identifiable) and, thus, controllable. "The neat Aristotelian universe in which evil is ontologically associated with nothingness, and both in turn associated with moral evil, provided a category in which to put the witches: they were Satan's helpers in his efforts to obliterate the Good." ${ }^{\text {56 }}$ This complex set of interlinked discursive operations represents a literary strategy absolutely fundamental to the text, one to be repeated again and again.

55 Ibid., II, Q. 1, c. 9, p. 135 [Schmidt, II, p. 98].

56 Russell, Witchcraft in the Middle Ages, pp. 115-16. 


\section{CHAPTER SIX:}

\section{SUPERSTITION, SCEPTICISM, AND THE CANON EPISCOPI.}

The interrelation between the long-term historical development of the ecclesiastical censure of occult practices and the impact that this development had upon the Malleus - the text itself being a microscopic recapitulation of certain central features of that very issue - is a highly complex problem. It entails whole series of interactive causal factors only a few of the more prominent of which may be discussed here. It is important to focus upon one particular thread of intertwined trends, the demonization of the figure of the learned Magician-Heretic within literate culture and the concomitant demonization of popular superstitious beliefs and practices, both developments mediated by a network of ecclesiastical discourses and institutions. Although any separation of the two trends is wholly superficial, the figure of the magician shall be discussed first, primarily because of the role it played in contributing to that collective pool of archetypal and stereotypical referents so heavily drawn upon by the Malleus.

One of the inherent difficulties in discussing late medieval views of occult knowledge is that magical thought was almost identical with the whole of natural philosophy, dominated by the set of metaphysical concepts stemming from the dialectical interaction between the realms of the microcosmic and the macrocosmic. 
The medieval ontology [of microcosmos] in its various forms had been able to supply a foundation for every branch of knowledge and practical endeavour. The fundamental idea of an all-pervading order allowed to link, at least in principle, ethics to metaphysics, physics to psychology. Microcosmism was [...an] aspect of this attempt at an encompassing synthesis. 1

Such occult concerns were anything but abstract; magical invocation served as

a primary means of utilizing supernatural forces presumed to be governing physical change. ${ }^{2}$ Working on this assumption, Brian Vickers has formulated a useful categorical division between magical (or pre-scientific) and scientific (or post-magical) modes of thought.

In the scientific tradition [...] a clear distinction is made between words and things and between literal and metaphysical language. The occult tradition does not recognize this distinction: Words are treated as if they are equivalent to things and can be substituted for them. Manipulate the one and you manipulate the other. Analogies, instead of being, as they are in the scientific tradition, explanatory devices subordinate to argument and proof, or heuristic tools to make models that can be tested, corrected, and abandoned if necessary, are, instead, modes of conceiving relationships in the universe that reify, rigidify, and ultimately come to dominate thought. One no longer uses analogies: One is used by them.

1 Allers, "Microcosmos", p. 363. However, for current attempts to resist such views of medieval magic and science in such totalizing descriptive categories, cf. Vickers, "Analogy versus Identity: the Rejection of Occult Symbolism 1580-1680", passim, and Vickers, "On the Function of Analogy in the Occult", passim.

2 "With the idea of general animation and universal intercommunication, there is combined the other that anything able to operate deliberately, instead of obeying blindly the "impetus" of its nature, may achieve domination over the rest of the universe. Thus, the belief in magic is the logical outcome of panpsychism. Magic comprises on one hand divination, on the other hand the active direction of the course of events. The oneness of all things is proven by the fact of knowledge. Where we know we are able to operate. The macrocosm, so far as it is in his reach, can be influenced by man's will." Allers, "Microcosmos", p. 400. Bert Hansen has commented that many "magical operations were simply manipulations devised to concentrate or utilize a certain virtue known to inhere in a substance or object", Hansen, "Science and Magic", p. 490. 
They became the only way in which one can think of or experience the world. 3

Generalizing from this somewhat, it is easy to see what precisely was at stake in the interminable debate throughout the central and late middle ages concerning the legitimacy of recourse to occult practises: it was the legal and/or moral propriety of the utilization of supernatural forces immanent within the structure of the cosmos which superseded the finite boundaries of any particular secular institution, most notably the Church.

Although medieval occult literature in no way forms a coherent genre ${ }^{4}$, certain dominant features may be discerned which also have left their mark on the Malleus Maleficarum. The single most important of these involved the relentless attempts of the clerical authorities to integrate occult practices and phenomena into an intellectual framework compatible with the neo-Aristotelian mode of explanation, a task more of ten than not philosophically painful. The inherently non-physical nature of verbal and symbolic magical invocation was in radical contradiction to the Aristotelian notion of physical contact as the sine

3 Vickers, "Analogy versus Identity: the Rejection of Occult Symbolism 1580-1680", p. 95 .

4 This diverse body or writings consists of such a dazzling array as university texts devoted to questions of "natural" phenomena, scholastic treatises on the erroneous beliefs of heretical religions and philosophical systems, episcopal condemnations of popular and/or heretical doctrine, papal proclamations, and diverse books of "secrets" or "experiments" usually falsely attributed to famous authors, most notable the De secretis mulierum of Albertus Magnus. Cf. Hansen, "Science and Magic", pp. 443-4. For a pioneering account of the as yet largely unexamined clerical necromantic texts, cf. Kieckhefer, Magic in the Middle Ages, ch. 7., pp. 151-75. 
qua non of cause-effect relationships. Especially troublesome in this regard were such anomalous items as bleeding corpses or, most notably, the entire set of popular belief centered around the malefic potency of the "evil eye", oculus malum, which blatantly undermined Aristotelian dogma concerning the mechanical causality of physical action at a distance. ${ }^{5}$ Scholastic science

was set within a fundamentally Aristotelian framework, that is, a framework which assumed contact-action as the basis of efficient causation, ruled out action at a distance through sympathy-antipathy and the world-soul, and was inhospitable to the notion of marvelous effects being produced through "natural" means. The Aquinian [scholastic] view, in other words, had the corollary that the extraordinary use of "natural" laws to produce extraordinary effects in nature was only possible through demonic intervention. ${ }^{6}$

To overcome such problems, the necessity of an interconnecting spiritual agency operating between bodies was frequently postulated, thereby simultaneously allowing for the reality of magical occurrences while providing a means of explanation consistent with Aristotelian causality. However, as the scholastics allowed for only a strict binary classification of spiritual principles - angelic or demonic - and as many occult practices, or, at least, the effects they produced, were seldom of a providential nature, the obvious deduction to be drawn was that all magical operation depended upon demonic participation for its

5 Cf. Hansen, "Science and Magic", pp. 487-8, 491. For the discussion of the gaze on maleficium provided by the Malleus, see below.

6 Rattansi, "Alchemy and Natural Magic in Raleigh's History of the World", p. 128. 
effectiveness. $^{7}$

As a result, thoughout the late medieval and early modern period, extensive discussion and incessant polemical exchange occurred precisely over this question of the necessity of demonic agency in all forms of magical praxis. Contingent political factors of ten played a vital role in the development of the debate. The papal court of Alexander VI served as an active center of reconciliation between spiritual magic and the precepts of religious faith, its efforts exemplified through the highly commendatory review, by papal commission, of the works of Giovanni Pico della Mirandola. 8 Thanks in no small part to the curia of Pope Alexander, magical and hermetic speculation served as integral components in the more general revival of neoplatonic philosophy. ${ }^{9}$ Even though neoplatonism, along with the magical and theurgic systems it inspired, were essentially of a religious and spiritual nature ${ }^{10}$, by the end of the fifteenth century there had been engendered continuous

7 Cf. Hansen, "Science and Magic", pp. 487-8. Cf. also Easlea, Witch-Hunting, Magic and the New Philosophy, passim; Trevor-Roper, The European Witch-Craze of the Sixteenth and Seventeenth Centuries, pp. 58-62. "The chief theological problem faced by the hermetic magicians was the Church's firm statement that there were only two kinds of spirits, angels and demons", Peters, The Maqician, the Witch and the Law, p. 163 .

16.

${ }^{8}$ Cf. Yates, Giordano Bruno and the Hermetic Tradition, pp. 113-

9 Cf. ibid., p 141.

10 Cf. Copenhaver, "Hermes Trismegistus, Proclus, and the Question of a Philosophy of Magic in the Renaissance", p. 84; Yates, "The Hermetic Tradition in Renaissance Science", p. 255; Zambelli, "Hermeticism and Witchcraft", p. 129. 
discussion, engrossing such prominent figures as Johannes Reuchlin ${ }^{11}$ and Johannes Trithemius ${ }^{12}$, concerning the exact nature of the relationships between the new magical intellectual systems and demonism. D.P. Walker has aptly summarized the inherent ambiguities presented by the esoteric philosophies to the orthodox ecclesiastical establishment that was still dominated by neo-Aristotelian scholasticism.

Natural, non-demonic magic is [...] an obvious threat to religion, since it claims to produce the same effects without any supernatural agent; its logical consequence is atheism or deism. Demonic or angelic magic avoids this danger, but is more evidently unacceptable to a Christian because it is a rival religion; the Christian revelation is unique and exclusive, and there is no room for any other religion. Prudent and wary Christians, therefore, prefer to consider all magic as demonic and to condemn it absolutely. 13

What is at issue here is not the history of the evolution of perceptions of magical doctrine from the fifteenth to sixteenth centuries, a topic far beyond the more limited horizons of this work, but rather the attempt to trace the most general features of a continuous discursive tradition based upon the association of the magical with the diabolical. Viewed in this way,

11 Cf. Zika, "The Magic Debate", passim; On Reuchlin's views cf. especially ibid., p. 120. "Philosophy needs to be made\%perate through an art of wonders; and such an art must be purified of its demonic aspects by an alliance with religion. In this way, philosophy, magic and religion become more closely interrelated, so that each overlaps with the other and is ultimately influenced and modified by its relationship to the other."

12 Cf. Zambelli, "Hermeticism and Witchcraft", pp. 134-8, 151-2.

13 Walker, Spiritual and Demonic Maqic, p. 89. Walker's discussion is undoubtedly the very best overall account of the tremendously complex issues that can only be touched upon here. 
such developments contributed directly to the broadest intellectual backgrounds of the historical gestation of the Malleus. This interrelation becomes even more obvious when attention is shifted to a corollary development, alterations in cultural representations of the figure of the magician, which had begun to acquire satanic overtones at the latest by the beginning of the thirteenth century. 14

There appear to be three primary factors at work underlying the gradual transformation in the perception of the magus. The first of these is the more general shift occurring in monastic literary traditions, particularly in hagiography. Throughout the thirteenth century there had been a steadily increased concern on the part of the monastic writers to depict the urgency of the threat posed by satanic power, a trend perhaps best represented by the Dialogus Miraculorum of Caesarius of Heisterbach. ${ }^{15}$ This development was closely linked to the success of the Gregorian reform movement which, in its efforts to provide an ideological justification for the political sovereignty of the ecclesia, encouraged the extension of spiritual exercise and discipline to the

14 "Condemned with the heretic, who himself emerges as a distinctive type in ecclesiastical literature of the twelfth century, the magician finally acquires a substantive, specific art in the world of the schools and the courts of the early thirteenth century", Peters, The Magician, the witch and the Law, p. 88 . See above, Chapter One.

15 On Caesarius, cf. Cohn, Europe's Inner Demons, pp. 69-71. The Malleus relates four anecdotes from the Dialoqus in II, 0.2, C.1 [Schmidt, II, pp. 197-206] - "Remedium Ecclesiasticum contra Incubus et Succubos Daemones", all of which demonstrate the power of the sacraments in repelling sexually aggressive incubi and succubi. 
secular world in combatting demonic assault. ${ }^{16}$ The second element is a series of changes in theological perceptions of divinity, the locus of emphasis shifting gradually away from God's immanence to his transcendence. Naturally, alterations in theological understanding necessitated the demand for the elicitation of a different variety of devotional responses on the part of the laity - love of God's goodness over fear of God's wrathful justice - resulting in an equally strong tendency towards the vilification of the most bitter enemies of the God of love, at this time the Jew and the Heretic. ${ }^{17}$ The third and perhaps most decisive factor is, as has already been touched upon, a reaction against the perceived upsurge in dualism resulting from the political successes of various heretical groups such as the Cathars. The demonstration of a linkage between heresy and diabolic magical power quickly became a leading means of providing a comprehensive explanation of the spread of heresy consistent with Catholic doctrine. ${ }^{18}$ Intertwined accusations of the practice of both heresy and diabolic magic served as one of the papacy's most powerful propagandistic weapons, as is evidenced in its struggles with the Ghibellines in the thirteenth

16 Cf. Peters, The Maqician, the Witch, and the Law, p. 93. "One function of the reform movement was precisely to sanctify the world outside the monastery, and part of this process was to reveal that world as plagued by demonic forces as was the secluded, highly structured and ultimately resourceful world of the monk."

17 Ibid., pp. 94-5.

18 "In addition to developing the role of the devil internally in orthodox theology [...] the challenge of Catharism itself became an example of demonic power." Ibid., p. 94. Cf. also Cohn, Europe's Inner Demons, chs. 9-10. 
and fourteenth centuries. 19

The apparent rise of popular heretical movements and the need of ecclesiastical authorities both to explain and render containable these movements, combined with scholastic speculation concerning demonic involvement in the production of magical effects, all served to provide a powerful impetus to incorporate the magician into the more general discursive formation of the satanic deviant. The apotheosis of this development was reached in September 1398 with the promulgation of the Conclusio of the theology faculty of the University of Paris, probably the best single summation of of ficial ecclesiastical views on magic and the legal status of the magician at the end of the fourteenth century. ${ }^{20}$ The political circumstances surrounding the issue of the document remain unclear. It is known, however, that the faculty played a decisive role in securing the conviction of the magician Johannes Barrensis in 1390 and issued subsequent condemnations of magic in 1425 and 1426..$^{21}$ The Conclusio, therefore, seems to represent but one part of a more general concern with magical-heretical practices in accordance with

19 Ibid., p. 104.

20 Cf. ibid., p. 143, "The opinion of the faculty of theology of the University of Paris, and that of Chancellor Gerson, may be taken as representing the most advanced and widely respected theological thought at the turn of the fifteenth century." The faculty is once mentioned briefly in the Malleus, in I, Q.2, p. 14 [Schmidt, I, p. 31]. It is unclear from the context whether the Conclusio is being referred to - "Praeter est articulus condemnatus in plersique Universitatibus, praecipue tamen Parisiensi, quod incantatur aliquis projicit Camelam in foream solo visu."

21 Peters, The Magician, the Witch, and the Law, p. 143. 
the ecclesiastical policy at the time. The Conclusio begins with a highly critical account of ceremonial treasure magic, denouncing all those as guilty of idolatry who were engaged in ritual magic or other such superstitious practices, managing thus to establish a precise connection between magical ceremony and heretical unbelief. ${ }^{22}$ The document reiterates Augustine's strictures against superstitious practices - on the grounds that they violate baptism which in turn demands the reconciliation of the sinner to God through the Church - and proceeds to draw up a list of twenty-eight items of erroneous superstitious belief. Of particular importance is the false doctrine that the invocation of demons is not idolatrous ${ }^{23}$, that entering into either an explicit or implicit Pact with demons is neither a form of idolatry nor apostasy ${ }^{24}$, that it is permissible to engage in forms of magical activity not expressly sanctioned by the Church in order to accomplish a benevolent purpose ${ }^{25}$, that it is permissible to combat maleficia by perpetrating maleficia ${ }^{26}$, and that the ritualistic acts of divination by and invocation of demons are without genuine

22 Conclusio (1897), pp. 32-3.

23 Ibid., p. 34, "Quod per artes magicas et maleficia et invocationes nepharias querere familiaritates et amicitias et auxilia daemonum non sit ydolatria:"

24 Ibid., p. 34, "Quod inire pactum cum demonibus tacitum vel expressum non sit ydolatria vel species ydolatrie et apostasie."

25 Ibid., p. 34, "Quod licitum est uti magicus artibus vel aliis quibuscumque superstitionibus $a$ Deo et ecclesai prohibitis pro quocumque bono fine."

26 Ibid., p. 34, "Quod licitum sit aut etiam permittendum maleficia maleficiis repellere." 
effect. $^{27}$

Four years later the conclusions of the theology faculty of Paris were repeated almost verbatim in the De erroribus circa artem magicam issued by the university chancellor Jean Gerson. ${ }^{28}$ Following the Conclusio, Gerson argues that magic is a form of superstitious idolatry and should therefore be condemned on those grounds alone. He further claims that any form of assocation with demons, a necessary precondition of any magical operation, was predicted upon some kind of Pact, citing Leviticus 19 and 22 as well as Deuteronomy 11 and the infamous Exodus 22:18 as the scriptural authority for his argument, this being the first citation of the Exodus text with regard to the scholastic discussion of magical activity. 29

De lege Dei prohibente talia habetur expresse textus Levitici XIX, XXII et Deuter. XI; et in sanctorum grusaulis; in legibus quoque temporalibus multa peromnem modum, quas leges transgreditum qui talibus operum praesiterit: unde Exod. XXII; maleficos non patieris vivere. 30

27 Ibid., p. 35, "Quod per tales artes et ritus impios, per sortilegia, per carminationes, per invocationes, de monum, per quasdam invultuationes et alia maleficia nullus unquam ministerio demonum subsequatur."

28 Lynn Thorndike, with somewhat mixed reservations, described Gerson as "the Augustine of the early fifteenth century" because of his emphasis upon direct mystical intuition of God coupled with his exceptionally prohibitive attitudes towards sexuality that are evidenced by his uncompromising censure of Le Roman de la Rose; Thorndike, History of Magic, IV, pp. 114, 125. Significantly, De erroribus circa artem magicam was one of the texts reprinted along with the Malleus in the collected edition of Lyons 1669.

Peters, The Magician, the Witch, and the Law, p. 145.

30 Gerson, De erroribus circa artem maqicam (1973), p. 81. 
It is difficult to overestimate the subsequent influence of these two treatises. By subordinating a whole array of magical practices, both learned and unlearned, to scholastic examination and canonical classification as a form of idolatry, they exacerbated a hitherto nascent trend that was to prove durable throughout the whole of the fifteenth century, the homogenization of distinct magical practices and beliefs under a single juro-philosophical category demanding the appropriately repressive political action by ecclesiastical and secular authorities. This process of conflating two hitherto distinct cultural traditions was

an important step in the shaping of the witch-figure, because it identified those [wise] women who practised amatory magic, divination, fortunetelling, superstitious cures, and other semiprofessional services [...] with the formidable learned magicians who had been the object of meticulous theological and legal invective since the late twelfth century. Not superstitious practices alone, then, but the identification of these practices with the articulately defined and described and condemned magical arts, brought hapless women and their successors to the attention of the theologians and judges, spiritual and temporal. 31

The impact of these theological innovations upon the more practical surveillance and policing activities of the Church is most markedly evidenced in the changes undergone in the production and composition of penitential handbooks. Penitentials serve as one of the most valuable, if not indeed the primary, sources about the practice of popular magical rites throughout the Middle Ages, revealing the full degree of the complexity of the

31 Peters, The Magician, the Witch, and the Law; pp. 145-6. 
relationship between of ficial and unofficial religious precepts and practices. 32

The tremendous increase in the production of penitentials during the early Middle Ages reflected the need to enhance ecclesiastical discipline and social control, achieved through the deliberate systematization of sacramental and confessional practices, in the face of the disruption of the secular political order. Within this unabated decentralization of politicial authority, the local parish priests, equipped with a certified manual, served as the main representatives of ecclesiastical power and discipline, operating relatively autonomously from limited episcopal supervision. ${ }^{33}$ The political circumstances surrounding the production of the handbooks naturally exerted a direct influence upon their structure and content, the penitentials serving as a kind of compendium of popular superstitious practices to be of ficially identified and subjected to disciplinary action. "The 'questionnaires' of the penitentials

32 Cf. Gurevich, Medieval Popular Culture, p. 81. Cf. also ibid., p. 91, The magical world-view of medieval popular culture "cannot be regarded as mere petrified survival of the past. In fact it had entered into an intricate interrelation with Christian beliefs and ideas that had been assimilated, one way or another, by the common people. Traditional magic and Christianity did not form distinct layers or separate compartments in the medieval mind. A unity arose from their encounter - a unity surely not devoid of contradiction and ambivalence, but one in which old magical beliefs and Christian teachings found meaning and function precisely in their natural correlation."

33 Cf. McNeill and Gamer, Medieval Handbook of Penance, pp. 7, 27. Cf. also Nelson, "Society, Theodicy, Heresy", pp. 75-6, "Without adequate central co-ordination, internal organisation or infrastructure, the early medieval Church had no alternative to accomodation with regard to .... phénomènes folkloriques. It was only with the organisation of rural parishes, in few areas effective before the tenth century, that the church really got to grips with pagan survivals in the countryside." 
interpret[ed] all aspects of popular belief in categories of sin and trespass against Christian virtues induced by evil spirits" ${ }^{14}$ - accordingly, the handbooks are resplendent with popular beliefs about the traditional lamia and striga $^{35}$, including cannibalism, aerial flight and combat ${ }^{36}$, and nocturnal congregations of unspecified but undeniably sinister individuals. ${ }^{37}$ Magic is understood and defined almost exclusively as a form of unlawful divination, the condemnation of magicians and soothsayers a constant theme running thoughout the whole of penitential literature. ${ }^{38}$ What accounts for the pugnacious attitude of the penitential authors is not merely that magic/divination, in their view, involve recourse to supernatural powers rivalling those indigenous to Christianity and thereby constituting an alternative form of religious devotion, but that such practices are inextricable from the more basic underlying notion

34 Gurevich, Medieval Popular Culture, p. 94.

35 Cf. Cohn, Europe's Inner Demons, ch. 11. See above, Chapters One and Four.

36 For the prevalence of nocturnal transport and spiritual combat in popular religious beliefs, cf. Ginzburg, Night Battles, chs. 1 and 2. For a contemporaneous penitential account of bodily transport, $c f$. Burchard of Worms, Corrector, c. 151-2, reprinted in: McNeill and Gamer, Medieval Handbooks of Penance, p. 338 .

37 Almost without exception, the handbooks remain vague on the precise nature or function of such nocturnal assemblies. Cf. Gurevich, Medieval Popular Culture, p. 98, "It is noteworthy that the clerical authors of the penitentials are unable to define what, exactly, their parishioners do when they gather 'at the devil's behest' at their assemblies in field or forest; do they pray, make sacrifices, play or feast?"

38 Ibid., p. 88. 
of Fate ${ }^{39}$ and, as such, are anathema to the Catholic doctrine of the freedom of both divine and mortal will. What is at stake in the manuals, then, is not merely an attempt to subjugate populations to a particular variant of spiritual discipline but, at the same time, to expurge from them a rival form of religious consciousness, the pervasiveness of which was directly reflective of the tenuousness of the theo-political hold that Christianity had upon the lay populations of western and central Europe at this time. ${ }^{40}$

The most ef fective strategy available to ecclesiastical authorities in their struggle against neo-pagan religious beliefs was rigorously to deny the efficacy, if not indeed the very reality, of the items of belief populating the popular magico-religious imagination. Perhaps the best example of this process is the Canon Episcopi, arguably the most important ecclesiastical statement on magic issued during the early Middle Ages. A composite work of uncertain origin or authorship, though most likely a Carolingian capitulary of the late ninth century, the $\underline{\text { Canon first appeared in the De synodalibus causis et disciplinis ecclesiasticis }}$ libri duo of Abbot Regino of Prüm, composed in 906. The strength of its language, coupled with the sheer number of glosses and commentaries that it inspired, involving such prominent figures as Ivo of Chartres, Gratian, and

\footnotetext{
39 It is Gurevich's view that within penitential literature the notion of Fate is seen to extend "into that undifferentiated relationship between man and nature which characterizes agrarian societies", ibid., p. 97. Two, ch. 3 .

40 Cf. Delumeau, Catholicism Between Luther and Voltaire, Part
} 
Aquinas, are indicative of the extent to which ecclesiastical concern with popular superstition played a part in the gestation of the witch stereotype. ${ }^{41}$ Ironically, the Canon was to serve this purpose primarily as a negative reference point, representing a position against which later writers like Institoris were to define their own positions.

Although fairly lengthy, the portion of the Canon that most concerns us in the context of the Malleus is its succinct discussion, in Chapter 26 of Question Five, of popular beliefs concerning the alleged noctural flight and assorted activities of witches. ${ }^{42}$ As Jeffrey Burton Russell has commented on this remarkable passage,

The Canon [...] firmly links both the [popular] fertility rites and the related wild chase to demonism. As chief of a demon horde, Diana can now be equated with Satan, and her followers with worshippers of Satan [...] not only do the women ride out with her, but they obey her as their lady (domina) as opposed to their true Lord, Jesus Christ (dominum). And they meet secretly on specified nights to worship her. We are still far from the sabbat of the fifteenth century, but now for the first time many of the major elements of later witchcraft have been brought together, amalgamated and labeled as heres $y$ and diabolism. ${ }^{43}$

This is perfectly true from a purely formalist viewpoint - the Canon does indeed present a coherent view of malefic nocturnal activity that proved to be easily assimilable to later literary innovations concerning the Pact and the Sabbat

\footnotetext{
41 Russell, Witchcraft in the Middle Ages, pp. 75-8, 310-11.

42 See below, Appendix D.

43 Russell, Witchcraft in the Middle Ages, p. 80.
} 
which underlay the vital connection established between witchcraft and heresy/diabolism. ${ }^{44}$ What Russell fails adequately to emphasize, however, is that the Canon clearly presents such phenomena as illusory, the result of demonic artifice of the sort previously discussed. And it was precisely on this point, the question concerning the exact nature of demonic intervention in magical practices, that was to serve as the locus of those fundamental innovations in the ecclesiastical and scholastic discursive representation of popular occult belief.

Throughout the tenth to twelfth centuries the Canon's view of the illusory nature of demonic intervention proved to be dominant. Hence, the reproduction virtually verbatim of the Canon in the Corrector et Medicus of Burchard of Worms, one of the most outstanding of the early medieval penitential handbooks ${ }^{45}$ : like the Canon, the Corrector declares both the supposedly direct experience, as well as the very belief in the reality, of nocturnal demonic flight to be the result of diabolic deception. ${ }^{46}$ By the

44 See below, Chapter Seven.

45 The Corrector, "a rich mine" of paganism and folklore, is itself the nineteenth book of Burchard's much lengthier work, the Decretum, which he composed c. 1008-1012. Cf. McNeill, "Folk-Paganism in the Penitentials", p. 460 .

46 Cf. Burchard of Worms, Corrector, c. 90, in: McNeill and Gamer, Medieval Handbooks of Penance, pp. 332-3. In c. 70, Burchard expounds upon the noxiousness of such belief, altering the witchleader's identity from the Greco-Roman Diana to the more properly Teutonic Hulda. Cf. ibid., p. 331, "Hast thou believed that there is any woman who can do that which some, deceived by the devil, affirm that they must do of necessity or at his command, that is, with a throng of demons transformed into the likeness of women, (she whom common folly calls the witch Hulda), must ride on certain beasts in 
beginning of the twelf th century, however, a reverse trend was in effect with ecclesiastical and inquisitorial authorities stressing the need to approach malefic action as an objectively real phenomenon. One reason for this rather sudden turnaround were, of course, those changes in philosophical speculation upon magical operation, which necessitated the involvement of demonic agency. An additional factor at work, political in nature and ultimately inextricable from intellectual developments, lay in the growing need to comprise an effective strategy in combatting heresy. There can be little doubt that such concerns lay behind a wide variety of theological developments during the twelfth and thirteenth centuries, including what was to prove decisive in the subsequent development of penitential literature, i.e. the tremendous increase of scriptural exegesis upon the legalia of the Old Testament. ${ }^{47}$ The strategy of Catholic exegesis devised in response to heretical dualism operated simultaneously upon a theological and a judicial level. On the theological plane, orthodox commentary sought to undermine the heretical claim, most notoriously

special nights and be numbered with their company? If thou hast perticipated in this infidelity, thou shouldst do penance for one years on the apppointed fast days."

47 "Although its effect is elusive, we can suppose that the crisis [of heretical dualism] stimulated thought in two ways: the Cathars made an arbitrary use of the spiritual interpretation [of the Scriptures], dismissing the literal sense altogether in favour of a spiritual sense, where it suited them. They therefore brought out the need for careful definition of the relationship between the senses in Catholic exegesis." Smalley, "Thomas Aquinas and the Old Law", pp. 22-3. Cf. also Peters, The Magician, the Witch, and the Law, ch. 6. 
represented by the Bogomils ${ }^{48}$, that the God of the Old Testament was in fact the Evil Principle, by stressing the positive spiritual value of the legalia. Within the more mundane judicial sphere, Catholic exegetes seized upon the need to interpret legally and, ergo, to enforce physically, Mosaic declarations against idolatry and superstition. From this resulted a dramatic intensification of ecclesiastical censure against all practitioners of superstitious belief, in accordance with such Mosaic stipulations as Exodus 22.18. 49

Developments in scriptual exegesis were paralleled by similar trends in theological speculation, perhaps best exemplified by Thomas Aquinas. Summa Theologiae IIa IIae ("Secunda Secundae"), Q. 94-5 contains his most detailed discussions of the theological significance of popular superstition. For Aquinas, "Sic igitur superstitio est vitium religioni oppositum secundum excessum, non quia plus exhibeat in cultum divinum quam vera religio: sed quia exhibet cultum divinum vel cui non debet, vel eo modo quo non debet." ${ }^{50}$ In a similar vein,

Ad superstitionem pertinet excedere debitum modum divini cultus. Quod quidem praecipue fit quando divinus cultus exhibetur cui non debet exhiberi: Debet autem exhiberi soli summo Dei increato: [...] Et ideo,

48 Cf. Runcimann, The Medieval Manichee, ch. 1.

49 Cf. Smalley, "Thomas Aquinas and the Old Law", pp. 33-4. Cf. also Peters, The Maqician, the Witch, and the Law, p. 147, "The theologians' concern was far more directed at the general categories of idolatry and superstition and with magic as a sub-category of these than at magic alone."

1 , p. 443

50 Aquinas, Summa Theoloqiae, IIa IIae, (Rome, 1962), Q. 92, art. 
cuicumque creaturae divinis cultus exhibeatur, superstitiosum est. 51

It is clear that Aquinas is following the practice of collapsing the distinctions between the categories of popular superstition and improper forms of worship. According to him, the basic criterion to be employed in gauging the legitimacy of a religious practice is whether the action in question is performed with trust in either the true God or some dependent creature of God. If, however, philosophically irrational premises are involved, then the effects of that action must necessarily depend upon some supernatural being - i.e. a demon - who is attempting to usurp the devotion which properly belongs to God alone. ${ }^{52}$ This constitutes the essence of the category of harmful superstition, the invocation of a sacrifice to demonic entities. 53 Within this equation, superstition becomes tantamount to diabolism.

As might be expected, Aquinas devotes great time and effort to compiling extensive descriptive lists of various superstitious practices. Of particular concern to him in this regard is the misuse of the sacraments - that which properly belongs to God - leading him carefully to distinguish between 4

51 Ibid., IIa IIae, Q. 94, art. 1, p. 446.

52 Cf. Ibid., IIa IIae, Q. 94, art. 4, pp. 449-50; Cf. also Hopkin, The Share of Thomas Aquinas in the Growth of the Witchraft Delusion, p. 82. On this point, Aquinas is merely being orthodox. Superstition was most commonly defined in relation to a perverse misuse of the articles or properties of religion - the "use of holy things for power beyond what they in fact held, imputation of power to unauthorized observances, and the use of authorized observances without the proper intention", Kieckhefer, Maqic in the Middle Ages, p. 185.

53 Hopkin, The Share of Thomas Aquinas in the Growth of the Witchcraft Delusion, p. 89. 
such lawful and unlawful practices. ${ }^{54}$ When engaging in the various forms of ritualistic magic involving the sacraments, such as hanging written scriptural passages around the neck in order to avoid illness, it is essential to avoid the utterance of any form of incantatation or reference to demons, unknown names or false doctrines. It is prohibited to insert into the sacred words any written character apart from that of the Cross, or to place any faith in the ritualistic writing of the figures, because this would detract from the proper reverance owed to God. Furthermore, the ritualistic collection and preparation of medicinal herbs are permissible only if they are accompanied by a divine symbol, the Creed, or the Lord's Prayer. ${ }^{55}$ In general, however, most incantations derive their efficacy from demonic intervention and are therefore illicit. 56

To facilitate his discussion of popular practices, Aquinas subdivides superstition into three main categories, idolatry, divination, and observances. Idolatry is held to be the offering of the cult of divinity to demons via a

54 An especially pertinent undertaking, as so many superstitious and magical practices involved some form of sacramental magic or other such usage of Christian ritual. Cf. Kieckhefer, Maqic in the Middle Ages, p. 168.

55 "Necim collectionibus herbarum quae medicinales sunt aliquas observationes aut incantationes liceat attendere, nisi tantum cum symbolo divino aut oratione Dominica: ut tantum Creator omnium et Deus honoretur." Aquinas, Summa Theologiae, IIa IIaem Q. 96, art. 4, p. 463. For an extensive account of ecclesiastical prohibitions of popular magical ritual involving the sacraments, cf. Thomas, Religion and the Decline of Maqic, ch. 9 .

56 Hopkin, The Share of Thomas Aquinas in the Growth of the Witchcraft Delusion, p. 109. 
ritualistic act of sacrifice or oblation 57 ; divination bears a marked structural similarity, being defined as the acquisition of prescient knowledge through entering into a formal Pact with demons. ${ }^{58}$ Divination, in turn, is itself subdivided into three main classificatory types - "necromancy", which entails the explicit invocation of demons 59 ; "augury", which entails all forms of divination made in regards to the disposition or motion of some object; and "the casting of lots", in which men themselves perform some kind of ritual action to make a hidden thing become known. 60

The efforts of scholastic theologians such as Aquinas in formulating a coherent ideological framework that ascribed to superstition features of a religious system assimilable to heresy/diabolism had a decisive impact upon the

57 Cf. Aquinas, Summa Theologiae, IIa IIae, Q. 94, art. 1, pp. 446-7; cf. also Hopkin, The Share of Thomas Aquinas in the Growth of the Witchcraft Delusion, pp. 90, 92 .

58 Cf. Aquinas, Summa Theologiae, IIa IIae, Q. 95, art. 2, pp. 452. Cf. also Hopkin, The Share of Thomas Aquinas in the Growth of the Witchcraft Delusion, pp. 92-3, "Every divination proceeds from the operation of the demons, whether they be expressly invoked for that purpose or whether they thrust themselves into the vain inquiries of men in order to implicate the minds of men in vanity. Any attempt to investigate future things is vain whenever someone tries to foreknow the future from a source from which it cannot be foreknown. Whence divination is manifestly a species of superstition, since it involves a certain pact with the demons, whether tacit or expressed."

59 Necromancy is extensively sub-subdivided into numerous practices, such as "geomancy", "hydromancy", "aeromancy", and "pyromancy". Divination through "pythons" refers to the practice of obtaining foreknowledge through observing the utterances of the spiritually or demonically possessed; the term is derived from the Delphic cult of Python Apollo. Cf. Hopkin, The Share of Thomas Aquinas in the Growth of the Witchcraft Delusion, p. 93; and Malleus, I, Q. 2, passim. $452-4$

60 Cf. Aquinas, Summa Theologiae, IIa IIae, Q. 95, art. 3, pp. 
subsequent development of penitential literature. Penitentials served as the point of convergence of innovative discursive stratagems, the handbooks turning the comparatively scattered condemnations of previous centuries, "coming from diverse sources and possessing little binding force, into the beginnings of a systematic concept of diabolic temptation and human vulnerability."61

Thirteenth-century theologians and confessors, aided by such texts, finally came into possession of a sizeable body of "documentary sources upon which to erect a systematic view of magic ${ }^{\prime \prime} 62$, complete with a new technical vocabulary, divinatio and sortilegium being "the two generic terms commonly used to designate the various magical arts." ${ }^{" 63}$ Representative of those trends were manuals such as the Liber Penitentialis of Robert of Flamborough, with its parallel denunciations not only of diabolism ${ }^{64}$ but also of its spiritual

61 Peters, The Magician, the Witch, and the Law, p. 80.

62 "Simultaneously with the fear and repression of heresy, the growing awareness of and fear of magic on the part of theologians and lawyers drew the two closer together in the penitentials", Peters, The Maqician, the Witch, and the Law, p. 80.

63 Ibid., p. 142.

64 Cf. Robert of Flamborough, Liber Penitentialis, (Toronto, 1971), Book III, c. 3, "De Sortilegio", p. 158, "Sortilegium impedit promovendum et dejicit promotum; sed hoc intelligo de illis sortilegis qui daemonibus immolant, vel imagines vel alia baptizant, vel de corpore Christi sortilegia faciunt. Quicumque aliquid tale fecerit, vel consilium vel auctoritatem vel auxilium vel consensum ad hoc praestiterit, etsi occultum fuerit, nec promovebitur nec post promotionem ordinis habebit executionem. De aliis sortilegis hoc non credo nisi infamia notati fuerint. Idem mihi videtur de illis qui sortilegos consilunt et divinos." 
twin $^{65}$, divinatory magic.

Although not a penitential handbook itself, the Malleus shares enough of the particular structural features and thematic concerns of the literature to warrant examination from this perspective. In this light, the first noteworthy feature is that virtually the whole of the first two sections of the Malleus, like the handbooks of the twelfth and thirteenth centuries, is devoted to refuting the essential scepticism of the Canon Episcopi. The text of I, Q.1, "Introductio" [Schmidt, I, pp. 1-20] is, in fact, centered on an attempt to confound those unnamed, but presumably sceptical clerics who had proved resistant to Institoris' inquisitorial claims - who deny the notion of either the objective physical reality or the inherently demonic nature of bewitchment. 66 In its lengthy rejoinder, the text emphasizes that

Quia auctoritates Scripturae sacrae dicit quod daemones habent

${ }^{65}$ Cf. ibid., Book v, c. 6 "De Divinatoribus", pp. 258-78.

66 In II, Q. 1, c. 3, p. 111 [Schmidt, II, p. 42], Institoris laments the influence of scepticism concerning the reality of nocturnal flight in impeding the prosecution of witches: "[...] ad Ecclesiae sanctae intolerabile damnum, ubi iam multis annis impune ex hac pestifera opinione permanserunt, seculari brachio puniendo facultatem amputando." In II, Q. 1, c. 14, p. 157 [Schmidt, II, pp. 148-9], Institoris indirectly refers to clerical opposition to his dissemination of the doctrine of demonic invlovelment in the bewitchment of cattle - interestingly, this is one of the few places in the Malleus where the author refers to himself in the first person: "Haec ideo posui, cum plures haec alia, quae posita sunt, aestimant populo non esse propenda propter periculum informationis cum sit impossibile, aliquem per praedicatorem posse informari ratione tacta. Potius autem sunt in detestationem tanti criminis, et ut Iudices in ultionem tanti sceleris scilicet, fidei abnegationis, amplius inardescent sunt praedicanda: Licet non semper: plus etiam ponderant seculares huiusmodi temporalia damna, cum magis terrensis implicantur affectionibus quam spiritualibus, unde et cum eis talia posse fieri affirmantur, in punitionem ipsorum amplius saeviunt: sed tamen astutiam Diaboli quid explicare potest." 
potestatem supra corporalia et supra imaginationem hominum, quando a Deo permittuntur, ut ex multis Scripturae sacrae loci notatur. Ideo illi, qui dicunt maleficium nihil esse in mundo, nisi in existimatione hominum, etiam non credunt esse daemones, nisi in existimatione vulgi, tantum ut errores, quos homo sibi ipse facit, ex sua aestimatione imputet daemoni. Et quod etiam ex imaginatione vehementi aliquae figurae apparent in sensu tales quales homo cogitat, quod et tunc creduntur daemones videri, vel etiam malefici. Et quam haec vera fides repudiat, per quam angelos de coelo cecidisse, et daemones esse credimus ideo et fatemur ipsos ex subtilitate naturae suae multa posse, quae nos non possumus, Et illi qui eos ad talia inducunt facienda, malefici vocantur, haec ibi: Quia vero infidelitatis in baptizato, haeresis nominatur; ideo tales de haeresi reprehenduntur. 67

The very beginning of the Malleus is then predicated upon a negative formulation of the position that it continuously strives to act against, establishing its own unimpeachable orthodoxy through a direct appeal to absolute authority. The text proceeds to refer to the Canon directly, claiming it to be the source of current heretical scepticism in two basic ways: the Canon explicitly declares both the belief in nocturnal flight in the company of Diana (or Herodias) and the transformation of human into animal to be the fruit of phantasmatical imagination and not of actual demonic intervention. Like its literary predecessors, the Malleus is not concerned with countering sceptical arguments against the reality of maleficium as such; the question at issue is rather whether the supposed physical effects of maleficia are produced by diabolic magic, and whether any changes or misfortunes that do occur are in fact the result of the ritualistic act of bewitchment, as the witches themselves

67 Malleus, I, Q.1, p.2 [Schmidt, I, pp. 3-4]. 
believe. 68 The text is involved in a highly complex strategy that operates upon both semantic and political levels: it has to delineate the fine but vital distinction - inherited from the convoluted discursive practices of the preceding witchcraft literature - that lay between phantastical experience and demonic agency, while at the same time undermining the potential for sceptical objection that may be derived from the recognizable authority of the Canon.

We have already seen how Institoris attempted to solve the first half of this equation through his deployment of a complex model of Thomistic causality. 69 In a way compatible with this stratagem, the ecclesiastical authority of the Canon is approached in a suitably duplicituos manner; opponents who derive their justification from the Canon have in fact misunderstood it.

Praeterea si quis verba Canonis diligentur inspexerit, considerabit quatuor quae Praedicatories, et Sacerdotes per Ecclesias sibi commissas omni cum instantia populo praedicare debent, scilicet, quod extra unum Deum nemo arbitretur aliquid esse numinis vel divinitatis. Secundo, quod cum Diana vel Herodiade equitare, est cum Diabolo (qui se ita fingit et nominat) transmeare. Tertio, quod talis equitatura sit tunc phantastica quando Diabolus mentem per infedilitatem sibi subiectam agitat taliter ut ea quae solo spiritu siunt, corporaliter fieri credantur. Quarto, quod tali domino habeant in omnibus obedire. Unde ad maleficiales actus haec

68 Cf. ibid., I, Q. 1, pp. 2-3 [Schmidt, I, p. 4], "Alij duo errores daemones et errorum naturalem potentiam non regantes, sed inter se quoad effectum maleficialem et ipsam maleficam diffidentes in quantum unus concedit maleficam realiter cooperari ad effectum, non tamen verum, sed phantasticum. Alter vero per contrarium effectum realem in laeso concedens, sed maleficam phantastice putat cooperari." 
verba extendere est absurdum, cum sint diversae species. ${ }^{70}$

It is, in truth, anything but clear that this constitutes a proper

reading of the Canon. What Institoris has, however, effectively accomplished here, is to provide a self-referring, to say nothing of self-serving, interpretation of the Canon consonant with the scholastic demand of the presence of satanic agency in all varieties of maleficium, and to employ it as part of a polemical assault against those (clerical) sceptics who would base their political resistance to his witch-hunting activities upon a non-Thomistic reading of the text. Scholastic metaphysics thus neatly dovetails with inquisitorial politics. Having established the authority of his own position through the unilateral dogmatic refutation of the legitimacy of any rival interpretation, Institoris is now clear to drive his point home, laying the basis for a synthetic account of maleficia encapsulating the basics of his own Thomistic-scholastic position in opposition to sceptical criticism:

Nec valet, si dicatur, quod etiam phantasia sit quid reale, quia sicut phantasia ut talis, nil potest efficere nec concurrere ad daemonis operationem nisi per pactum initam cum daemone, in quo pacto malefica se totam obtulit et astrinixit Diabolo vere et realiter et non phantasticae aut imaginarie solum: ita etium oportet quod cooperatur Diabolo vere corporaliter. Nam et ad hoc sunt omnia maleficorum opera, ubi semper aut per visum aut per locutionem alicuius malefici instrumenti repositi sub limine domus operatione sua maleficia exercent. ${ }^{71}$

\footnotetext{
70 Ibid., I, Q.1 p. 6 [Schmidt, I, p. 12].

71 Ibid. I, Q. 1, pp. 5-6 [Schmidt, I, pp. 11-12].
} 
The Malleus provides no single explanation of Satan's need to enter into a contractual relationship with the witch. ${ }^{72}$ In I, Q.2, p. 10 [Schmidt, I, pp. 21-2] Institoris suggests that the witch is a necessary conduit for the transfer of diabolic spiritual power into the material realm ${ }^{73}$ - an obviously fallacious argument as it is blatantly contradicted by the text's later assertion of the demon's capacity directly to effect physical objects spatially via their control over local motion. ${ }^{74}$ The altogether more convincing argument is the moral one, in which Satan, even though he has no physical need to do so, chooses to form alliances with witches in order to secure their damnation; "Diabolus conatur potius per maleficas propter suum lucrum in perditionem animarum."75 By employing the witch as the channel for his malevolent power, Lucifer is able to realize a number of nefarious designs.

72 The main topic addressed in the second question of Part One, "An Catholicum sit asserere, quod ad effectum maleficialem semper habeat Daemon cum malefico concurrere, vel quod unus sine altero, ut Daemon sine malefico, vel e converso talem effectum possit producere", ibid., I, Q. 2, p. 9 [Schmidt, I, p. 20].

73 Cf. ibid., I, Q. 2, p. 10 [Schmidt, I, pp. 21-22], "Omnis actio per contactum: Et quia non est aliquis contactus Daemonis ad corpora, cum nihil habeat cum eis communae: ergo utitur aliquo instrumento illi influendo virtutem laedendi per contactum. Iuxta hoc etiam, quod maleficia possint fieri absque operere Daemonum." Cf. also ibid., I, Q. 2, p. 14 [Schmidt, I, p. 31], "Quod substantiae spirituales non possunt transmutare corpora ad aliquam naturalem formam, nisi adminiculo alterius agentis."

74 Cf. ibid., II, Q. 1, C. 3 [Schmidt, II, pp. 41-53] "De modo, quo localiter transferuntur de loco ad locum." See below.

75 Ibid., I, Q. 1, p. 4 [Schmidt, I, p. 8]; cf. also II, Q. 2, c. 7, p. 205 [Schmidt, II, p. 263], "Constat enim quod Diabolus maleficia operatur per se, nec in illis rebus indiget consensu. Aut et perditionem maleficiae quaerit, unde et ipsam aliquo modo cooperari cogit." 
Et si dubitatur, an magis Daemon pios affectet homines et creaturas per seipsum laedere quam per maleficas, dici potest quod nulla est cooperatio. In infinitum enim plus affectat per maleficas aedere. Tum quia maiorem infert Deo contumeliam, creaturam sibi dicatam usurpando. Secundo, quia cum Deus amplius of fenditur, amlius sibi nocendi hominibus potestas permittitur. Tertio propter sui lucrum, quod in perditionem statuit animarum. 76

By establishing a necessary connection between witch and demon ${ }^{77}$, itself the result of the development of scholastic discourse on the diabolic nature of magical action, the text is able to situate the subject of the witch into a total network of discursive referents and signifiers which not only demonizes her, but, in accord with innovations in penitential literature, places her within the context of an organized anti-Christian religion - that is, heresy. The witch, once having been identified through a discursive field of stereotypical associations - Witch-Diabolism-Superstition-Heresy - is by that very act subjugated to a grid of taxonomic classifications which render her susceptible to systematic ecclesiastical discipline and judicial procedure. The inherently dialectical relationship between scholastic pronouncement on magic and penitential discipline against superstition is clearly manifest in the composite literary figure of the Witch-(Magician)/Heretic, its cultural reality constructed and mediated by texts such as the Malleus. A more detailed analysis of how the

76 Ibid., II, Q. 1, c. 7. p. 131 [Schmidt, II, p. 87].

77 Cf. ibid., I, Q. 2, p. 15 [Schmidt, I, p. 34], "Catholicum venitatem concludamus, quod ad maleficiales effectus, de quibus ad praesens loquimur, maleficos cum Daemonibus semper concurrere, et unum sine altero nihil posse efficere." 
text performs such a transformation shall now be provided.

The first phase of this classification process is exclusion. Witches are understood as a highly specific group of occult transgressors, defined through their difference from any other.

Concludendum igitur ex omnibus praemissis Catholicum et verissimam assertionem, quod malefici, sunt, qui daemonum auxilio propter pactum cum eis initum, maleficiales reales effectus, permittente Deo, procurare possunt, non excludento quin et praestigiosis effectus et phantasticos etiam per media praestigiosu producere valeant. Sed quia praesens speculatio super maleficiales effectus versatur, qui plurimum ab aliis differunt: ideo per hoc nihil ad propositum, cum tales potius sortilegi vel incantatores dicantur, quam malefici. 78

At no point does the text expressly differentiate between witches and (learned) magicians as separate categories, which is perhaps symptomatic of the extent to which the conflation of the two classes had been internalized by late fifteenth-century theological discourse. Instead, the Malleus follows the Summa Theologiae, ("Secunda Secundae"), Q. 95, art. 4, in precise terms, placing

78 The text becomes somewhat confusing at this point. Although it refers to the fourteen divisions of superstition provided by Aquinas in his Summa Theologiae, IIa IIae, Q. 92, pp. 442-4, it does not list them. Instead, it offers only this rather cryptic comment regarding rival classes of supernatural offenders - "Et species sub qua huiusmodi mulieres continentur, vocatur species pythonum, in quibus daemon vel loquitur vel mira operatur. Et est saepius prima in ordine. Species autem qua malefici continentur vocatur species maleficorum [sic]. Et quia inter se plurimum distant, nec opertet quod qui in una specie laborat, quod etiam sub aliis comprehendatur", Malleus, I, Q. 1, p. 5 [Schmidt, I, p. 10]. Cf. also ibid., II, Q. 1, c. 3, p. 116 [Schmidt, II, p. 52], "plures sint superstitionum species: ut pote quatuordecim: Inter quas maleficarum species, supremum in maleficiis et nocumentis continet gradam: et species Pythonum, ad quam reduci possunt, [...] minimum gradum." What seems to be hinted at is a separate category of supernatural malefactors who are predominantly male and who, presumably, possess a set of defining characteristics different from that of the female witch described by the text. Unfortunately, the Malleus never broaches the topic again. 
witchcraft within the second sub-category of superstition, divination.

"Maleficorum autem ritus reducitur ad secundum genus superstitio, scilicet ad

Divinationem, quae fit per expressum Daemonum invocationem: Cuius etiam

sunt tria genera, scilicet, Necromantia, Plantearij, seu potius Mathematici, et

Divinatio per Somnia."79 The range of definition is narrowed even further,

for witchcraft is to be regarded solely as that form of divination which

explicitly involves diabolic intervention.

Maleficorum ritus deducuntur ad secundum genus superstitionis, quod dicitur Divinatio: rebus vero superstitiose uti in observaniis quibusdam reductur ad terium genus, ideo argumentum non est simile: demum etiam, quia reducuntur non ad quamlibet Divinationem, sed ad illam, quae sit per expressam Daemonum invocationem, et hoc etiam cum multis modis fieri possit, scilicet per Necromantiam, Geomantiam, et Hydromantium. 80

In I, Q. 16, [Schmidt, I, pp. 195-201], the text's taxonomic categories are expanded to cover all varieties of superstition in distinction to maleficium.

79 Ibid., I, Q. 2, p. 12 [Schmidt, I, p. 27]. None of these headings are particularly well-defined. The only place where the text attempts a comparative definition is in I, Q. 2, p. 16 [Schmidt, I, pp. 36-7], "Respondetur quod quia duplices in his observantiis fieri possunt imagines Necromanticae et Astronomicae: et inter haec talis est differentia. Quod in Necromantis, semper fiunt expresse invocationes Daemonum, propter expressa pacta cum eis inita. Inspiciatur solutio secundi argumenti praefatae quaestionis. In Astronomicis vero sunt pacta tacita, et ideo nulla invocatio nisi fortassis tacita, puta, puta propter figuratum, figurata et characterum signa, quae eis inscribuntur. Et iterum imagines Necromanticae, vel fiunt sub certis constellationibus, ad recipiendum certos influxus et impressiones corporum coelestium, etiam certis figuris et characteribus insigniti, ut in annulo, lapide vel aliqua pertiosa materia. Vel fiunt simpliciter absque observantia constellationum, sed indifferenter ex quacumque materia, etiam vili, ad inferendum maleficia, ubi et quando ad aliqua loca reponuntur: et de his effectibus cum suius imaginibus iam sermo est, et non de alijs. Ideo argumentum non facit ad propositum." 
Aquinas' tripartite classification system is here followed most precisely.

Praemissa denique veritas, quoad enormitatem criminum in maleficiis probatur per comparationem ad alia opera Magorum et Divinatorum. Nam cum quatuordecim sint species circa opera superstitiosa, ex triplici genere Divinationum. Quorum primum fit per manifestam Daemonum invocationem. Secundum per tacitam solam considerationem dispositionis, vel motus alicuius rei, ut syderum, dierum, horarum et huiusmodi. Tertium, per considerationem alicuius actus humani, ad inquirendum aliquid occultum, quae Sortium nomen habent. ${ }^{81}$

The various forms of divination are subdivided accordingly:

Et species primi generis divinationis, quae fit per expressam Daemonum invocationem, sint praestigium, Divinatio somniorum ${ }^{82}$, Necromantia ${ }^{83}$, Divinatio pythonica ${ }^{84}$, Geomantia, Hydromantia,

81 Ibid., I, Q. 16, p. 84 [Schmidt, I, pp. 195-6].

82 "In tertia denique specie, quae et somniorum divinatio dicitur, dupliciter observatur. Primo, quando quis utitur somnis, ut valeat aliquid occultum investigare ex revelatione malorum spirituum, cum quibus habentur pacta expressa, quando scilicet ad hoc invocantur. Secundo, vero, quando quis utitur somnis ad cognoscendum futura, secundum quod somnia procedunt ex revelatione divina, vel ex causa naturali intrinseca, vel extrinseca, quantum potest se extendere talis virtus, non erit illicita divinatio." Ibid., I, Q. 16, p. 85 [Schmidt, I, p. 198]. The text's discussion of the practice of divination through dreams occasions the reference to the witch of Breisach's testimony concerning nocturnal flight and the Sabbat. Ibid., I, Q. 16, p. 86 [Schmidt, I, p. 200]. See below. In this way the text's classification of superstition is brought into direct relation to the issue of ecclesiastical scepticism.

83 "In secunda denique specie, quae et Necromantia dicitur, et fit per mortuorum apparitionem, vel locutionem, cum ut dicitur 3.1ib.EthiC. NEKROS Graece, mors dicitur Latine, mantia vero divinatio. Faciunt autem talia per sanguinem hominis, aut alicuius animalis, super quibusdam characteribus, scientes Daemonem sanguinem amare, id est, eius effusionem, et peccata. Unde fit ubi mortuos ab inferis se vocare putant, ad respondendum ad interrogata, Daemones in eorem similitudinibus apparentes, talia exercent." Ibid., I, Q. 16, p. 85 [Schmidt, I, p. 197]. This represents the text's only attempt to define necromancy.

84 The text's only description of "Divinatio pythonica" is found in I, Q. 16, p. 86 [Schmidt, I, pp. 200-1]. "In quarta denique specie quae per Pythones, a Python, Appolline, iuxta Isidorum, qui auctor divinandi dicitur fuisse, exercetur, non per somnia, aut per mortuorum allocutionem, sed per vivos, ut in arreptitiis, qui sic arrepti a 
Acromantia, Pyromantia, et aliorum cultus. S. Thom. secunda secundae, q.95. et 26.q.5. igitur. et q.5 nec mirum. 85 Species denique secundi generis Genethliaci, Aruspices, Augures, Omen observantes, Chiromantia, et Spatulamantia.

Species etiam tertij generis variantur, secundum omnia illa quae Sortium nomen habent, ad inquirendum aliquid occultum, scilicet, per considerationem punctorum, festucarum, figurarum in plumbo liquef actarum. Et de his S. Thom. ubi supra, et 26. quaest.2. et q.4. per totam. 86

Despite its comparatively detailed exposition, the main purpose of $Q .16$ is to

identify non-malefic forms of superstition in order to discard them.

Unde causa brevitatis de aliis minoribus speciebus divinationum haec probare non expedit, ubi maiores excedere noscuntur. Nam ubi praedicatori placet applicare alias species $^{87}$, potest, ut Geomantiam, quae fit circa corpus terrestre, ut in ferro vel lapide polito. Hydromantiam, quae fit in aqua vel crystallo Aeromantiam, quae fit in aëre. Pyromantiam, quae fit in igne, Aiolorum, quae fit in visceribus animalium immolatorum in aris Daemonum. Licet hae omnes per expressam Daemonum invocationem fiant, nulla tamen est comparatio ad maleficia Maleficarum, cum ad nullum nocumentum hominum, iumentorum et terrae frugum tendunt directe, sed ad futurorum praecognitionem. De aliis etiam speciebus divinationum, quae cumtacia invocatione, et etiam per tactum, ut sic pactum erga Daemones practicantur, ut sunt Genethliaci, seu Astrologi, sic dicti propter natalium considerationes. Auruspices, qui dies et horas observant. Augures, qui gustus et garritus avium, et Omen, quo verba hominum observant. Et Chiromantici, qui ex lineamentis manuum aut spatulis

Daemonibus, vel voluntarie, aut involuntarie, ad praedicendum tantummodo futura, et non ad alia flagitia perpetranda agitantur, qualis fuit illa puella de qua Act. 16. clamando post Apostolos, quod essent veri servi Dei. Unde indignatus Paulus, impetravit spiritui exire $a b$ ea: Patet quod modica sit comparatio per respectum ad maleficas et eorum opera, quae utique sic ob magnitudinem facinorum, et enormitatem criminum, [...] ut supra habitum est, nuncupantur."

85

See above.

86

Ibid., I, Q. 16, p. 84 [Schmidt, I, p. 196].

87 This points out the intended pedagogical function of the text. 
animalium divinant. Si cui placet, inspiciat praeceptorem $\mathrm{Nider}^{88}$, circa secundum praeceptum, et plura inveniet, quomodo sint licita, et quomodo non. Maleficarum vero opera nunquam sunt licita. 89

It is clear that the text's main concern is not to provide concise terminological definitions, but to pursue to the utmost its strategy of establishing a necessary interrelationship between witchcraft and heretical diabolism, enabling it to subject the wide array of popular magical superstitious beliefs and practices, subsumed under the term maleficium, to the classificatory and explanatory categories provided by scholastic demonology. In II, Q. 1, c. 5, p. 123 [Schmidt, II, p. 70], the Malleus identifies six main forms of bewitchment, all in complete accordance with popular belief concerning the powers of cunning folk.

Unde primo notandum, quod cum sex modis laedere possunt absque modis, quibus alias creatures laedunt. Et unus sit, quo amorem malum ingerunt viro alicui ad mulierum, vel mulieri ad virum. Alius est, quo odium vel invidiam, in aliquo seminare procurant. Tertius in his, qui maleficiati dicuntur ne vi generativa uti valeant ad foeminam: vel viceversa foemallae ad virum: vel etiam aliis modis absorum procurando [...] Quartus, cum in membro aliquo hominem aegrotare faciunt. Quintus, cum vita privunt. Sextus, cum usam rationis auferunt. 90

Bewitchment of the male sexual function shall be the main topic discussed here, not only because of its prominence in popular magical beliefs, but also because it is the form of malefic transgression that receives the most detailed treatment

88 Cf. Nider, Praeceptorium, Part Two, "De Assumptione Nominis Dei \& iuramento", chs. 1-5, pp. 177-216.

89 Ibid., I, Q. 16, pp. 86-7 [Schmidt, I, p. 201].

90 Ibid. See above, Chapter Three. 
in the Malleus. ${ }^{91}$ Citing the Summis as authority, the text recognizes seven distinct methods of inducing sexual dysfunction and infertility through maleficium. 92

Et hoc septemplici maleficio, ut in bulla tangitur. Venereum actum et conceptus in utero variis inficiendo Maleficiis. Primo, mentes hominum ad inordinatum amorem, etc. immutando. Secundo, vim generativam impediendo. Tertio, membra illi actui accommoda auferendo. Quarto, homines praestigiosa arte in bestiales formas mutando.. Quinto, vim generatium, quo ad foemellas destruendo. Sexto, absorsum procurando. 93 Septimo, infantes Daemonibus offerendo, absque alijs animalibus et terrae frugibus, quibus varia nocumenta inferunt: de quibus in sequentibus tractabitur. ${ }^{94}$

Little attention is devoted to illuminating the actual mechanics of demonic sexual dysfunction; the explanation provided is essentially the same as that for illusory transformation. This is most evident in the text's account of the

91. The topic is broached for the first time in I, Q. 8 [Schmidt, I, pp. 127-36] "An operatinam potentiam, seu actum Venerum Malefici impedire possint: quod Maleficium in bulla continentur." Further discussions on the matter are explicitly provided in I, Q. 9 [Schmidt, I, pp. 136-45]; II, Q. 1, c. 5 [Schmidt, II, pp. 69-75]; II, Q. 1, C. 6[Schmidt, II, pp. 75-8]; II, Q. 1, C. 7 [Schmidt, II, pp. 78-87]; II, Q. 2, C. 2 [Schmidt, II, pp. 206-12]; II, Q. 2, C. 4 [Schmidt, II, pp. 219-23].

92 Notably, the Malleus does not single out men as the sole victims of sexual bewitchment. Cf. ibid., I, Q. 8, p. 56 [Schmidt, I, p. 131], "Notandum insuper, quod non solum sit maleficium, ne quis actum illum execere valeat, sed etiam cliquando sit ne mulier concipiat, vel ut absorsum faciat."

93 This would hint at the text's later identification of midwifery as a primary form of witchcraft, an association which does not appear to have existed within the popular imagination; $c f$. Burghartz, "The Equation of Women and Witches", p. 67; Harley, "Historians as Demonologist: The Myth of the Midwife-witch", passim. see below. The main concern with identifying midwifery in this way seems to be connected to subsuming the popular view of midwives as abortionists under the more general stereotypical representation of the witch as infanticidal and cannibalistic. See below, Chapter Seven.

94 Malleus, I, Q. 6, p. 46 [Schmidt, I, p. 107]. 
popular belief concerning the witch's capacity physically to separate the virile

member from the body.

Nulli dubiam, quim maleficae quaedam mira operuntur circa membra virilia, ut ex visis et auditis plurimorum, imo et ex ipsa publica fama constat de hoc quod per sensum visus, aut tactus ventas illius membri cognoscebatur. Quod qualiter fieri potest dicendum: quod licet dupliciter fieri possit, scilicet, vere et realiter, ut argumenta prima tetigerunt, et praestigiosa operatione. Ea tamen, quae a maleficis sunt circa huiusmodi, non sicunt nisi praestigiosa, illusione: quae tamen illusio non habet locum in imaginatione patientis: Quia imaginatio eius potest vere et realiter aestimare aliquam rem non esse praesentem, licet per nullam operationem sensus exterioris, scilicet, visum, aut tactum percipit esse praesentem. 95

As one would expect, the text is given over to demonstrating the reality of these occurrences in such a way as to render them intellectually compatible with its own fundamental precepts - thus the highly scholastic rationalization of the interrelationship between femininity and sexual bewitchment. Witches, who are predominantly female, are more inclined to attack men via sexual

95 The passage contrives: "Unde potest dici vera ablatio membri ex parte imaginationis patientis licet non ex parte rei, quod qualiter fiat, sunt plura notanda. Primo, duo modi, quibus ista fieri possunt. Non mirum, quod Diabolus sensus humanos exteriores, de quibus supra tactum est, illudere potest, formas reservatus educendo ad principalia sua sensitiva. Decipit autem eos in sua naturali operatione, ut guod visibile est, sit illis invisibile, tangible intangibile, audibile inaudibile, et sic de alijs. Haec autem veritas ita nihil ponit ex parte rei quod omnia fiunt ex immutatione organorum destruendtium visum, auditum, etc. ut sunt occuli et manus, quibus immutatio iam fallitur, sensus, iudicium", Ibid., I, Q. 9, pp. 59-60 [Schmidt, I, pp. 138-9]. Cf. also I, Q. 8, p. 56 [Schmidt, I, p. 130], "Quod quia tale impedimentum sit interdum per obstrusionem vasis, vel etiam per motum localem, reprimendo rigorem membri, quae potius et facilius in viris contingere possunt, ideo plures viri maleficiantur, quam mulieres. Posset etiam quis dicere, quod ideo, quia plures mulieres superstitiosae sunt, quam viri, et potius allicere cupiunt viros quam mulieres." 
impairment because, as witchcraft is a result of unbridled lust ${ }^{96}$, they are more susceptible to emotions like sexual jealousy resulting from male matrimony. 97 In symmetrical fashion, witches are more likely to behave in this way precisely because they are women and therefore far more prone to be inordinately aroused by such powerful emotions as sexual jealousy and its concomitant desire to disrupt masculine procreation. 98 of even greater theological significance is the way in which the act of sexual bewitchment seemingly obeys the basic tenets of Catholic orthodoxy, for here, too, divine permission is the sine qua non of malefic efficacy.

Nam tactum est, quod maleficium non est solum opinione hominum, quasi nihil in re, imo effectus innumeri maleficiales accidere possunt vere et realiter Deo permittente. Ostensum est etiam quod Deus amplius permittit, super vim generativam propter maiorem eius corruptionem, quam super per alios actus humanos. Sed de modo, quo tale impedimentum procurator, est advertendum, quod non procurat solum

96 Cf. ibid., I, Q. 6, p. 46 [Schmidt, I, p. 106], "Omnia per carnalem on cupiscentiam, quae quia in eis est insatiabilis". See above, Chapter Four.

97 Cf. ibid., I, Q. 6, p. 47 [Schmidt, I, p. 109], "Et utinam experientia nos minime edocuisset, imo et odia talia etiam in Sacramento matrimonij coniunctus suscitatu per maleficia, et similiter per infrigidationes generativae potentiae, ut nec redditionem nec exactionem debiti matrimonialis locum pro prole habere valeant."

98 Cf. ibid., I, Q. 6, p. 46 [Schmidt, I, p. 107], "Quod quia tria generalia vitia, scilicet, infidelitas, ambitio et luxuria: praecipae in malis mulieribus, regnare videntur. Ideo illae prae caeteris maleficiis intendunt, quae prae caeteris illis vitiis deditae sunt. Iterum quia inter illa tria ultimum amplius praedominatur, ideo quia insatiabile, etc. Ideo et illae inter amitiosus amplius infectae sunt, quae pro explendid suis pravis concupiscentiis amplius mardescunt, ut sunt adulterae, fornicariae, et magnatorum concubinae." 
circa vim generativam, sed etiam vim imaginativam, seu phantasiam. ${ }^{99}$

The main reason for the seemingly inordinate power that witches exercise over this particular domain of human life is essentially theological, the inherent corruption of the sexual function resulting from Original Sin, thereby rendered subject to the realm of Satan.

Quod quia corruptio peccati prima, per quam homo factus est servus diaboli, in nos per actum generantem devenit: Ideo maleficij potestas permittitur Diabolo a Deo in hoc actua magis quam in alijs [...] Unde etiam [...] licet matrimonium sit opus Dei, tanquam ab eo institutum, ad huc per opera Diaboli interdum destruitur. Non quidem per violentiam, quia censeretur sic fortior Deo: sed ex Divina permissione, procurando impedimentum actus coniugalis, vel temporale, vel perpetuum. 100

Such theological profundities carry the most dire judicial consequences. The inducement via maleficia of sexual dysfunction, resulting in either the impediment of conception or the abortion of the foetus, is morally and legally tantamount to murder and should be regarded a capital of fense.

Quod quicunque propter vindicitae libidinem explendam, vel propter odium aliquid fecerit viro mel mulieri propter quod non possunt generare vel connsipere, reputatur homicida. Extra: de homicid [...] Maleficae, per maleficia talia procurantes, sunt secundum leges ultimo supplico

99 Ibid., I, Q. 8, p. 55 [Schmidt, I, p. 128]. Cf. also ibid., I, Q. 9, p. 59 [Schmidt, I, p. 137], "Si dicatur quod potest Divina permissione, tunc sic in praededentibus dictum est, quod Deus amplius permittit vim generativam maleficiari, propter primum corruptionem peccati, quae per actum generantem in nos deunit, ergo etiam amplius permittit super membrum illius potentiae generativae, ut ipsum totaliter auferat."

100 Ibid., I, Q. 6, pp. 46-7 [Schmidt, I, p. 108]. Cf. also ibid., I, Q. 18, p. 91, [Schmidt, I, p. 211], "Cur videlicet Deus potius super vim generativam permittit maleficia fieri quam super alios actus humanos [...] Est enim hoc propter foeditatem illius actus. Et quia originale peccatum inflictum ex culpa primorum parentum, per illum actum transfunditur: et exemplificatur etiam de serpente, qui primum iinstrumentum Diaboli fuit, etc." 
puniendae. 101

Having systematically identified the satanic malefactors, the text

goes on to provide a detailed set of protective measures for prospective victims of witchcraft.

Secunda Pars principalis huius Operi, quia est de modo procedendi, qui a maleficis inferendi observatur. Et per decem et octo capitula 102 distinguntur: cum duabus duntaxat difficultatibus: Querum una in principio super remedia praeservativa, ut videlicet quis maleficiari non possit, altera in fine super remedia moventia maleficia, et per quae maleficiati curari possunt. Cum secundum Philosophum in 4. Physic. removens et prohibens concidunt, et sut causae per accidens, ideo ut per haec totale fundamentum huius horrendae haersis habeatur. 103

In a fashion strikingly reminiscent of his treatment of women as witches,

Institoris proclaims that a philosophical demonstration of the a priori necessity of his position is not necessary as he is relating actual events on the basis of his own personal experience.

Et quia in mortali iam laboramus materia, unde argumentis variis et declarationibus institere opus non est, cum ea quae per capitula sequentur sint per praecedentes questiones sufficienter discussa. Ideo precamur in Deo lectorem, ne demonstrationem in omnibus quaerat ubi accomodata sufficit probabilitas, ea deducendo, quae constant, aut visi vel auditas propria experientia, aut fide dignorum relatibus esse vera. 104

Institoris adds further authoritative weight to his arguments, not merely as a

101 Ibid., I, Q. 8, p. 57 [Schmidt, I, p. 131].

102 In fact, Part Two of the Malleus is subdivided into two questions, Question One "Quibus maleficus volere non possent" with sixteen chapters, and Question Two "Sequitur super modum quo iumentis maleficae varia nocumenta inferunt" with eight chapters.

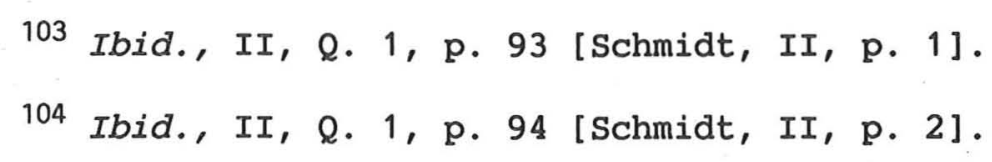


professionally trained theologian, but also in his capacity as a veteran inquisitor highly experienced in the actual practices and beliefs of the religiously suspect; from this point onwards then, the focus is not upon the logical proof of the validity of his claim, but on the ways in which the author can render his empirical findings consistent with official ecclesiastical and theological discourse.

The text commences its lengthy discussion of the various forms of maleficia by identifying those fortunate people who are immune to it magistrates officially empowered to proceed against witches ${ }^{105}$; those who employ the sacraments and rites of the Church, most notably exorcism ${ }^{106}$, in a legally correct manner; and those blessed by angels. ${ }^{107}$ In complete accordance with the precepts of the Conclusio of 1398, the Malleus is adamant in its refusal to recognize the legitimacy, either theological or judicial, of the

105 A claim which is blatantly contradicted, among other places, in III, Q. 15 [Schmidt, III, pp. 89-98], which treats the various ritualistic counter-magic procedures to be employed by authorities while prosecuting suspects.

106 Cf. ibid., II, Q. 1, p. 95 [Schmidt, II, p. 6], "Nam adhoc exorcizantur ab Ecclesia, et omino sunt efficacissima remedia ad praeservandum se ab insultibus Maleficarum."

107 Cf. ibid., II, Q. 1, p. 94 [Schmidt, II, p. 3], "Tria sunt genera hominum beneficiati a Deo, quibus illud pessimum genus suis maleficiis nocere non potest. Et primi sunt qui publicam contra eos iustitiam exercent, aut officio aliquo publico adversus eos institut. Secundi, qui ritibus Ecclesiae servatis et veneratis, ut aquae benedictae aspersionem, per Salis consecrati sumptionem, per candelabrum in die purificationis, et frondium, in die palmarum consecratorum, usum licitum, cum ad hoc talia Ecclesia exorcizat ut vires. Daemonis imminuant, se muniunt, de quibus modis patebit. Tertij sunt, qui per sanctos Angelos variis et infinitis modis beneficiantur." 
recourse to maleficium to combat maleficium. Any form of illicit magical practice, even if it is for the benign purpose of preventing or curing illness, is necessarily diabolic - and thus heretical - by definition. Invoking this set of criteria guaranteeing the authenticity of the truly miraculous, the text claims,

Quia uti auxilio Daemonum non est licitum [...] quia videlicet est apostasia a fide. Et quidem quod sine auxilio Daemonum non possint dissolvi: Probatur, quia aut dissolvitur humano artificio, aut diabolica aut divina potentia. Non primum: quia inferior potestus non potest infringere superiorum, cum nihil agat ultra suam virtutem. Non etiam divina, quia hoc esset opus miraculorum: et cum illa Deus ad suam nutum operatur, et non ad instantiam hominum. ${ }^{108}$

This portion of the Malleus - II, Q. 2, "Introductio" - is perhaps most highly representative of the text's underlying discursive strategy of systematically subordinating all forms of popular magic to the classificatory categories of scholastic demonology. Hence its uncompromising condemnation of the illegality of the supplication of cunning folk for aid against bewitchment.

Praeterea hoc quod communiter toleratur, in usa practicatur, licet sit illicitum, sed hoc communiter practicatur, quod tales maleficiati currunt ad mulierculas superstitiosas, a quibus saepissime liberantur, et non per sacerdotes aut exorcistas. Ergo practica ostendit, quod auxilio Daemonum maleficia tolluntur, cuius tamen auxilium quaere cum sit illicitum, etiam non est licitum maleficia tollere, sed patienter suffere. 109

The Malleus adroitly utilizes late medieval theological discourse on the satanic nature of magical action as a means of obtaining a blanket ideological

8].

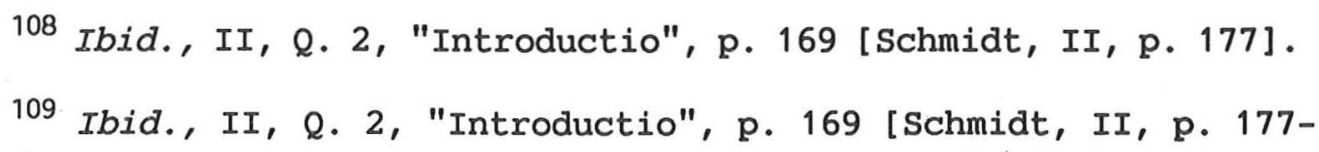


condemnation of the superstitious anti-bewitchment practices of the cunning folk - "Ideo notandum, quod maleficium aut tollitur per alium maleficum simulet per aliud maleficium: aut tollitur, non quidem per maleficium, sed per maleficiales ritus et illicitos." Such matters are beset with inherent difficulties.

Primum remedium est omino illicitum, tam ex parte auctoris, quam et ipsius remedij. Sed tamen quia fit dupliciter, quia aut cum nocumento illius qui maleficium intulit, aut sine nocumento, fit tamen per maleficiales ritus et illicitos, tunc comprehenditur sub secundo modo, videlicet ubi maleficium tollitur, non per maleficum alium, sed per maleficiales ritus et illicitos, tunc iterum illicitum iudicatur licet non tantum sicut primum. 110

Reiterating the Church's official view on magic - now undeniably associated

with heretical maleficium - the text concludes,

Unde summarie dicere possumus, quod per tria et tribus modis remedium redditur illicitum quando scilicet tollitur per maleficum alium, et per maleficia, videlicet virtute Daemonis alicuius. Secundo, quando non per maleficium, sed honestam personam tollitur, sic tamen quod superstitiosis remediis maleficium, quod uni personae aufertur, alteri infertur, et hoc Herum illicitum. Tertio, quando aufertur sine eo quod alteri infertur utitur tamen Daemonum invocatione expressa vel tacita, tunc iterum illicitum. 111

In contrast to such remedies, Institories goes to some lengths in stressing the necessity of the of ficially recognized sacraments of the Church in the combat against maleficia.

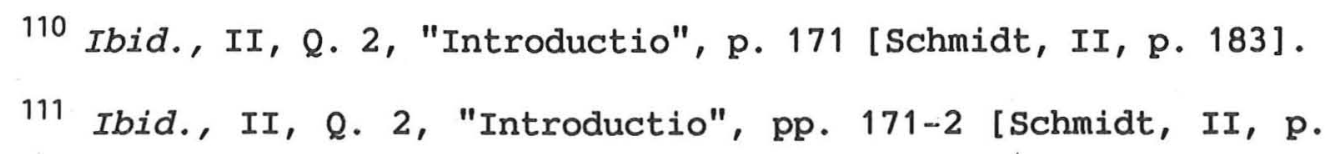


Quod sicut Deus et natura non abundant in superfluis, ita non deficiunt in necessariis quare et necessario fidelibus contra huiusmodi insultus Daemonum sunt data non solum remedia praeservativa [...] verum etiam remedia curativa, cum alius non sufficienter fidelibus a Deo provisum esset, et opera Diaboli viderentur fortoria geribus Dei. 112

This leads to prolonged discussion about the theological and canonical propriety of the performance of exorcism and other permissible remedies by unof ficially empowered persons, like e.g. devout laymen. 113 The crucial issue at stake here is the precise theological and judicial status of such practitioners.

Primo, an non habens exorcizatus ordinem, ut scilicet laicus, vel secularis persona valeat licite Daemones, aut eius maleficia exorcizare: Ubi tres aliae annectuntur, qualiter videlicet sunt licit: Et de septem conditionibus, quae requiruntur ad carmina et benedictiones, ut quis valeat fecum talia deferre: et tertio qualiter moribus sit exorcizandus, et Daemon coniurandus. Secundum principale, quid agendum ubi gratia sanitatis per exorcismis non obtinetur. Et tertio, quod remedia, non iam verborum, sed operum cum solutionibus certorum argumentorum. ${ }^{114}$

For Institoris, the problem is not a new one since the unofficial usage of exorcist ritual can be traced as far back as the apostolic era. ${ }^{115}$ What

112 Ibid., II, Q. 2, "Introductio", p. 170 [Schmidt, II, p. 179].

113 The discussion takes place in II, Q. 2, c. 6 [Schmidt, II, pp. 234-59], "Remedia per licitos exorcismos Ecclesiae, contra quaescunque infirmitates a maleficiis illatos, et de modo exorcizandi maleficiatos."

114 Ibid., II, Q. 2, c. 6, p. 193 [Schmidt, II, pp. 234-5].

115 Cf. ibid., II, Q. 2, c. 6, p. 194 [Schmidt, II, pp. 236-7], "Nam principiam horum fuit sanctissimum: sed sicut omnia Daemonis instructu depravantur mediantibus Daemonibus et malis hominibus, ita et divina nomina. Apostoli enim et sancti viri secundum illud Marc. ult. In nomine meo Daemonia eiicient: infirmos visitarunt, et orationes super eos per sacra verba fuderunt, deinde successa temporis sacerdotes devote similia rite peregerunt, propter quod devotissimae orationes et sancti exorcismo reperiuntur in antiquis hodie Ecclesiis ad omnia, quae homines facere aut pati poterant, per devotos viros applicari, olim sine superstitione, sicut etiam hodie literari et 
constitutes a unique development, however, is the corruption of the proper employment of such ritual by improper devotional practices, which effectively transform it into a debased form of superstition, along the lines of the definition provided by Aquinas. "Superstitio est religio supra modum servata, id est, religio modis vel circunstantis malis et defectuosis practica. Etiam superstitiosum est, quicquid traditione humana nomen religionis usurpat absque superioris authoritate. $" 116$

Behind this extended discussion of exorcism, one may detect echoes of that long-standing debate over the comparative legality of the various forms of unof ficial access to sacred and/or supernatural power which underlies so much of the historical development of the ideology of witchcraft persecutions - in this way, the text is thoroughly immersed in the mainstream of contemporary theological discussion. The Malleus strives to provide a strict set of guidelines which establish the legitimacy of the non-clerical usage of sacramental ritual and magic in distinction to superstitious practices.

Sed ad propositum nostrum modo, quando fit aliquid opus ex virtute religionis Christianae, ut ibi quisque vellet infirmos subvenire per aliquam orationem et benedictionem per verba sacra: de qua materia nunc intendimus, talis habet considerare septem conditiones, quae si reperiuntur, talis benedictio censetur licita, etsi fiat per modum adiurationis, per virtutem divini nominis, per virtutem operum Christi, quae ex sua nativitate, passione, preciosa morte, etc. innotuerunt, per quae etiam Diabolus victus et eiectus fuit, dicentur illae benedictiones,

sacrae Theologiae Doctores reperiuntur, qui infirmos visitantes similia verba aegrotis applicant et non solum daemoniacs."

116 Ibid., II, Q. 2, c. 6, p. 194 [Schmidt, II, p. 238]. 
carmina et exorcismi licit: et hi qui practicant possunt dici Exorcistae, aut Incantatores liciti iuxta [...] Incantatores dicuntur, qui artem aliquam verbis peragunt. 117

As would be expected, the seven conditions which the text provides are taken nearly verbatim from Aquinas' discussion of superstitious devotion. ${ }^{118}$ The Malleus, following Aquinas, states that nothing in the words to be used in the ceremony may suggest either explicit or implicit demonic invocation ${ }^{119}$; any benedictions of charms employed must not contain any unknown names ${ }^{120}$; no form of written characters are to be used other than the Cross ${ }^{121}$; no

117 Ibid., II, Q. 2, c. 6, pp. 194-5 [Schmidt, II, pp. 238-9].

118 So scrupulous is it in its usage of the Angelic Doctor, that the Malleus even reproduces Aquinas' discussion of the propriety of employing the written sacred words in combatting illness by hanging them around one's neck, as previously discussed. Cf. ibid., II, Q.2, c.6, pp'. 196-7 [Schmidt, II, p. 243], "Primo quidem, quid sit quod scribitur, utrum sit ad invocationes Daemonum pertinens, manifeste tunc non solum superstitiosum imo illicitum, et apostasia a fide in dicatur, ut supra tactum fuit saepe.

Similiter etiam cavendum ne continent ignota nomina, etc. accipe conditiones supra positas: et tunc sicut licitum est huiusmodi super infirmos ore proferre: ita licitum est illa secum deferre. Praefati autem Doctores respectum habent et damnant: cum quis ad figuras et literas scriptas maiorem haberet adverentiam et respectum, quam ad intellectum verborum."

119 Ibid., II, Q. 2, c. 6, p. 195 [Schmidt, II, p. 239], "Ut verba non contineant aliquid, quod pertineat ad invocationem Daemonum expressum vel tacitam."

120 Ibid., II, Q. 2, c. 6, p. 195 [Schmidt, II, p. 239], "Ne benedictiones seu carmina contineat aliqua nomina ignota."

121 Ibid., II, Q. 2, c. 6, p. 195 [Schmidt, II, pp. 239-40], "Ne materia verborum aliquid falsitatis contineat: quia sic eius effectus non posset expectari a Deo, cum ipse non sit testis falsitatis." The text provides an interesting, albeit brief, account of popular practice. "Sic quaedam uctulae in suis carminibus utuntur rithmatizando: Beati Virgo Iordanem transivit, et tunc Sanctus Stephanus ei obviavit, et eam interrogavit, et multur alias falsitates." 
faith is to be placed in the ritual act of the composition, as all is due solely to $\operatorname{God}^{122}$; in either the writing or the verbal recital of Holy Scripture proper reverence must be paid to the words alone ${ }^{123}$; finally, the working of the sought-for effects must be left to God. 124

On the basis of these guidelines, the Malleus evaluates the legality of the practices performed by Swabian peasant women described in II, Q. 2, c.7 [Schmidt, II, pp. 259-69], "Remedia contra grandines et super iumenta maleficiata", the text's most detailed discussion of the popular magical rituals used in combatting bewitchment. ${ }^{125}$ The counter-magic rituals which the Malleus declares to be licit are so because they demonstrate the proper reverence to the precepts of the Faith - at least according to the authors' own criteria. To cite just one example:

Contra grandines vero et tempestates, ultra ea, quae supra de signo

122 Ibid., II, Q. 2, c. 6, p. 195 [Schmidt, II, p. 240], "Ne ibi contineantur vana et characteres sinscripti praeter signum crucis.

123 Ibid., II, Q. 2, c. 6, p. 195 [Schmidt, II, p. 240], "Ut in allegatione et prolatione divinorum verborum, vel scripturae sacrae respectus solum habeatur ad ipsa sacra verba et ad intellectum eorum, et ad Dei reverentiam, seu ad virtutem divinam a qua expectatur effectus, vel ad sanctorum reliquias a quibus praefata expectantur secundario, licet a Deo principaliter."

124 Ibid., II, Q. 2, c. 6, p. 195 [Schmidt, II, p 240], "Ut committatur effectus qui expectatur, divinae voluntati: qui scit, utrum sanitas vel tribulatio plus prosit invocanti vel minus, vel an obsit."

125 A large part of this discussion is derived from Nider, Part One of the Praeceptorium, chs. 1-22, pp. 2-177. Cf. especially C.9 "De speciebus superstitionum, \& de gravitate peccati huius, ac de remedijs licitis \& illicitis, \& quibus ex causis daemones sciant futura", pp. 55-60. 
crucis erecto, hoc remedium practicatur: lapilli enim tres ex grandine in ignem sub invocatione Sanctissimae Trinitatis subiiciuntur, et oratio Dominica, cum Angelica salutatione bis aut ter adiungutur, atque Evangelium Ionnis, In Principio erat Verbum, cum signo Crucis undique contra tempestatem, ante et retro, et ex omni parte terrae subinfertur. Et tunc, cum in fine replicat trinies, Verbum iaro factum est, et trinies ex post dixent; Per Evangelica diciat fugiat tempestas ista, subito, siquidem tempestas ex malefico fuit procurata, cessabit. Haec verimissima experimenta nec suspecta iudicantur. Hoc ipsum enim, quod lapilli in ignem proiiciuntur, si absque invocatione Divini nominis fieret, superstitiosum censetur. ${ }^{126}$

To quell any possible objections regarding either the propriety or even the

efficacy of such measures, the text provides a lengthy defence based upon the

alleged testimony of accused witches.

Et ad hoc, quod Malefica quaedam a Iudice interrogata, an per aliquem modum tempestates a maleficiis concitatae sedari possent. Respondit, possunt, per hoc videlicet, Adiuro vos grandines, et ventos, per quinque vulnera Christi, et per tres clavos qui eius manus et pedes perforarunt, et per quatuor Evangelistas sanctos Matthaeum, Marcum, Lucam, et Ionnem, ut in aquam resoluti descendatis.

Fatentur etiam multae licet quaedam sponte, quaedam in torturis et difficulter, quod quinque sunt per quae multum impediuntur, aliquando in toto, aliquando in parte, aliquando ne in personam hominis siant, aliquando ne in suis amicis: et sunt, fidem integram, vel Dei praecepta servantibus se signo crucis, et orationibus munientibus, ritus et caermonias Ecclesiae colentibus publicam iustiam bene exequentibus, et Christi passionem verbi vel mente ruminantibus. 127

Anticipating the possibility that some may still view such practices with suspicion because they do not adequately understand the means necessary to distinguish between superstition and true devotion, the Malleus provides a list

126 Ibid., II, Q. 2, c. 7, pp. 205-6 [Schmidt, II, pp. 264-5].

127 Ibid., II, Q. 2, c. 7, p. 206 [Schmidt, II, pp. 265-6]. 
of five rules delineating the proper usage of the sacraments ${ }^{128}$ - the glory of God has to be the true object of the ritual ${ }^{129}$; the practice must be accompanied by a ritualistic mortification of the flesh ${ }^{130}$; the act has to be performed in full accordance with the statutes of the Catholic $\operatorname{Church}^{131}$; the action must bear some natural resemblance to the result desired ${ }^{132}$; and the act must be performed without error. ${ }^{133}$

128 The text is rather ambiguous on the source of the authority of these guidelines: "Ista enim eliciuntur ex glossa super illud Apostoli ad Coloss. 2, quae sunt rationem habentia sapientiae in superstitione: quae dicit: Superstitio est religio supra modum servata: ut etiam supra tactum est", ibid., II, Q. 2, c. 7, p. 206 [Schmidt, II, p. 266].

129 Ibid., II, Q. 2, c. 7, p. 206 [Schmidt, II, pp. 266-7], "Quod in ominibus operibus nostris gloria Dei debeat esse principalis finis noster."

130 Ibid., II, Q. 2, c. 7, p. 207 [Schmidt, II, p. 267], "Quod attendatur an opus quod fit, sit ad exercitium vel refrenatiuum concupiscentiae, vel abstinentiae corporalis, modo tamen virtuti debito, hoc est, secundum ritum Ecclesiae vel secundum moralem doctrinam."

131 Ibid., II, Q. 2, c. 7, p. 207 [Schmidt, II, p. 268], "Quod attendatur, an opus sit secundum statum universalis Ecclesiae, vel secundum sacrae scripturae testimonium, vel saltem secundum particularem Ecclesiae ritum aut de consuetudine generali, quae secundum Augustinum pro lege habenda est."

132 Ibid., II, Q. 2, c. 7, p. 207 [Schmidt, II, p. 268], "Quod inspiciatur, an opus quod fit, habeat naturalem proprietatem ad effectum, qui expectatur; a.lias enim si hoc non habet, censetur superstitiosum. Ex qua consideratione characteres ignoti, et nomina susppecta, etiam imagines astronomicae et necromanticae refutantur omnia tamquam suspecta. Ideo et ex hoc consideratione non possumus dicere, quod deportatio reliquiorum, aut Eucharistiae contra diabolicas infestationes, sint superstitiosa, imo religiosissima, cum ibi tota salus nostra contra adversarium contineatur.

133 Ibid., II, Q. 2, c. 7, p. 207 [Schmidt, II, p. 268], "Quod opus quod fit non praebeat occasionem scandali vel ruinae: quia tunc, licet non esset superstitiosum, tamen propter scandalum esset dimittendum, vel differendum, vel occulte sine scandalo faciendum." 
As can be seen, the Malleus incorporates many of those trends and concerns, both theological and judicial, which underlay the development of a particular form of theological literature concerned with the classification of proper and improper forms of religious observance. In this way the Malleus shares certain concerns with the penitentials in identifying and condemning a particular form of religiosity as superstition. The text follows the handbooks not only in their classification of various forms of spiritual and supernatural transgression, but also in their recommendations for the punishment of such deviance.

Nam lex divina in plerisque locis praecipit, maleficas non solum esse vitandas, sed etiam occidendas, cuiusmodi poenas non imponeret si non veraciter et ad reales ef fectus et laesiones sum daemonibus concurrerent. Mors enim corporaliter non infligitur sine corporali et gravi peccato, sed aliud de morte animae quae ex phantastica illusione seu etiam tentaione oriripotest [...] Nam Deuter. 18. praecipitur omnes maleficos et incancatores interfici. Levitici etiam 19. dicitur, Anima quae declinaverit ad Magos et ad Ariolos et fornicata fuerit in eis, ponam faciem meam contra eam et interficiam eam de medio populi mei. Et iterum 20. Vir vel mulier in quibus pythonicus vel divinus spiritus fuerit, moriatur, et lapidibus obruent eos. Ed dicuntur pythones in quibus daemon operatur miros effectus. 134

The theological classification of maleficium is thereby rendered inextricable from the judicial condemnation to death. It is in its political strategy in combatting the perceived superstitious errors where the Malleus departs from previous theological writing, best exemplified by the Canon Episcopi. The earlier literature sought to defuse the potential threat of popular magico-

134 Ibid., I, Q. 1, p. 3 [Schmidt, I, pp. 5-6]. 
religious beliefs by contesting the veracity of their basic tenets. With the rise of scholasticism, inquisitorial jurisprudence, and the political imperative to prosecute suspected religious deviants, the Malleus had to invert this practice without casting aspersions upon the ecclesiastical authority of the earlier pronouncements. Not merely had superstition to be identified and classified; it had to be resisted precisely because of the threat posed by the objective reality of the demonic presence. This task, at the same time, committed the author(s) to opposing not only popular superstition but also the epistemological scepticism of established ecclesiastical opinion. In order better to understand how the text seeks to accomplish this formidable goal, the Malleus will now be situated within the context of the contemporaneous development of fifteenthcentury inquisitorial literature. 


\section{CHAPTER SEVEN:}

\section{INQUISITORIAL TEXTS AND THE SABBAT.}

The interrelationships between the development of the views of maleficium and ars magica presented in late medieval inquisitorial manuals and the ways in which such perceptions were reproduced within the Malleus are as ambiguous as they are complex. A crucial aspect of this irreducible problem lies in the confused - and of ten confusing - history of the handbooks themselves, with their own notoriously imprecise terminology. In addition to drawing together many of the key terms in the history of magic - sortilegium, divinatio, ars magica, maleficium - the manuals greatly expanded upon the previous works of earlier canonical lawyers and penitential authors on the nature and sinfulnes of supernatural transgression. ${ }^{1}$ The development of inquisitorial literature and

1 "In the inquisitorial literature of the late fourteenth and fifteenth centuries, the separate semantic developments of such terms as maleficus, divinator, sortilegus give way to a process of identifying all these terms with each other and with magical arts [...] In the fifteenth century the invective against heresy is applied to magicians and later to witches, by bringing them before the inquisitorial tribunals, not only of the Inquisition itself, but before secular judges as well; the ancient condemnation of magic is strengthend by its identification with idolatry, superstition, and apostasy." Peters, The Maqician, the Witch, and the Law, p. 161. Peters later on elaborates upon the difficulties inherent in assigning fixed meanings to the terms employed. "Although I have not been able to provide a full semantic history of such key terms as maleficium, I have suggested that in Latin, terms that had remained relatively discrete before the fourteenth century began to be used interchangeably after that period. When one reads 'divinatio vel ars magica', for example, in a fifteenth century text, it is clear that the hitherto limited definition of divinatio has been expanded and become interchangeable with the term ars magica. The history of the maleficium also shows narrow and broad meanings. When maleficium and sortilegium became consistently forms of idolatria and superstitio, theologians and inquisitors acquired greater freedom in dealing with them in relation to other crimes that had been considered manifestations of idolatria and superstitio." Ibid., p. 168. 
the concomitant extension of the field of inquisitorial jurisprudence stemming from its literary pronouncements, form a particularly revealing example of the inextricable relationship between discursive representation and juro-political power argued for in this dissertation. These developments share certain overlapping features with the trends discussed above while at the same time possessing certain idiosyncratic characteristics of their own, no one pattern coalescing into a harmonious, continuous whole serving as a determinant of the rest. Throughout the fifteenth century, popular beliefs and practices had once again come under the surveillance of religious authorities, but this time their actions were governed by the new resources and materials bequeathed to them by the momentous ecclesiastical developments of the twelf th and thirteenth centuries, inquisitorial judicial and political power. But whatever the change in technique, the object of concern remained constant - the well-defined features of the satanic deviant. What worried late medieval theologians and lawyers was what had

worried their patristic and later sources: evidence of practices that had been condemned from the days of Tertullian and Justin Martyr as sinful. The inquisitors and their colleagues on secular benches responded to fifteenth and sixteenth century phenomena with the intellectual resources of fifteenth and sixteenth century lawyers and theologians. ${ }^{2}$

In the third-century Roman law had declared all forms of magical practice to be punishable offences; by the fourth century all accused suspects

2 Ibid., p. 15. 
were to be subjected to torture. ${ }^{3}$ Up until the mid-fourteenth century magic received comparatively sparse attention from judicial textbooks, what concern there was was focused upon the ways in which the magical inducement of sexual impotency could be regarded as a legal impediment to marriage. ${ }^{4}$ By the second half of the fourteenth century, however, a definite shift in outlook was perceptible, the direct result of changing ecclesiastical attitudes towards heresy coupled with the introduction of Roman law and inquisitorial techniques as a means of enforcing the Church's political authority. ${ }^{5}$ Heresy had increasingly come to be seen as a form of lese-majesté, particularly following the promulgation of the Vergentis in sentium by Innocent III in 1199 during the Fourth Lateran Council. Ecclesiastical developments prompted a parallel response in secular circles, Emperor Frederick of Hohenstaufen issuing the new imperial constitution from 1220 to 1231 , which not only tremendously facilitated the state's persecution of suspected heresy, but did so by explicitly identifying

${ }^{3}$ Cf. ibid., p. 150 .

4 Cf. ibid., p. 148. Peters suggests that the most representative text of such approaches to maleficium is the Summa de cassibus of Raymond of Penafort. Cf. ibid., pp. 78-9, 98-101.

${ }^{5} \mathrm{Cf}$. ibid., p. 155, "It is in the general context of criminal law after the thirteenth century that the prosecution of magicians and witches ought to be understood." Although without doubt a dialectical process, it is difficult to determine where to place the emphasis. The majority of historical scholarship tends primarily to focus upon the revival of Roman jurisprudence in the early thirteenth century; however, for a contrasting assessment cf. Van Caenegem, "Le Preuve dans le Droit du Moyen Age Occidental", pp. 691-755. Cf. especially ibid., p. 740, "Il nous semble toutefois que le renouveau du droit romain et la réception de la torture dans la pratique ecclésiastique ont du contribuer à la diffusion de l'examen en Europe." 
it with maleficium. ${ }^{6}$ A complex juro-theological discourse was initiated, predicated upon the mutual identification of the satanic-heretic with the magician. Two of the outstanding representative texts of this development that proved to have a decisive influence upon inquisitorial practice were both papal issuances, first, the Quod super nonnullus of Alexander IV, composed on 13 December 1258 and subsequently incorporated into the Liber Sextus. The only text in that collection expressly dealing with magic, the letter instructs inquisitors to proceed against magicians if they were suspected of harbouring heretical beliefs.

Quod super nonnullis quaestionum articulis, in quibus causa fidei tangitur, nos consulere voluistis, solicitudinis vestre prudentiam in domino commendamus [...] Ad illud autem, quod quaeritur, utrum ad inquisitores heresis pertineat, de divinationibus et sortilegis, que contra aliquos sibi denunciantur, cognoscere ac punire talia exercentes? breviter respondetur [...] Cum negotium fidei, quod summe privilegiatum existit, per occupationes alias non debeat impediri, inquisitores ipsi de iis, nisi manifeste haeresim saperent, ratione huiusmodi of ficii sibi commissi se nullatenus intromittant, sed eos relinquant suis iudicibus pera debita castigandos. $^{7}$

The second crucial text is the Decree issued by Eugenius IV in 1437. Like the

Conclusio of 1398, the Decree's preoccupation with the by now collapsed categories of popular superstition and learned magic expressed within the language of heretical demonism and coupled with a rudimentary representation

${ }^{6}$ Cf. Peters, The Maqician, the Witch, and the Law, pp. 151, 160.

7 Alexander IV, Quod super nonnullis, reprinted in Hansen, Quellen, p. 1. 
of the Sabbat, represents exceptionally clearly the outcome of the centurieslong process of the gradual fusion of the parallel trends of the juro-theological condemnation of magic-superstition and heresy-diabolism.

Inquisitores haereticae pravitatis ubilibet constituti: Ad nostrum non sine garvi mentis amaritudine pervenit auditum, quod plerosque Christi sanguine mercatos adeo tenebrarum princeps, ut eos suorum damnationis lapsusque participes efficiat, eius in fascinavit astutiis, quod ipsi detestabiles illius suorumque satellitum suasus et illusiones coecitate noxia sectantes, demonibus immolant, eos adorant, ab ipsis responsa prestolantur et acceptant, illis homagium faciunt et in signum desuper chartam scriptam vel quid aliud tradunt, cum ipsis obligatoria, ut solo verbo, tactu vel signo maleficia, quibus velint, illis inferunt sive tollant, infirmitates sanent, aeris intemperiem provocant, et super aliis nefandis pacta firmant, seu quod talia conceperint praesumptores extant, imagines vel alia constitunt fierique procurant, ut ipsi daemones inde constringantur, cum illorum invocationibus maleficia perpetrant, baptismatis et eucharistiae, necnon aliis sacramentis et quibusdam illorum muteriis, etiam in eorum sortilegiis et maleficiis abuti non formidant, imagines de cera aut alia re cum invocationibus etiam huiusmodi; factis baptizant vel ordinant baptizari; rurusque eorum aliqui sacratissimae crucis eiusdem, in qua pro nobis omnibus pastor ipse pependit, mysterium non reverentes in sculpturis et alias praefatae crucis signo varia approbria motibus execrandis irrogant et de sacramentis ipsis, quae nullatenus iteranda forent, ausibus superstitiosis iterare praesumunt. 8

The theme of the idolatrous magician was thus placed at the very

heart of the inquisitorial manual's treatment of heresy during the thirteenth and fourteenth centuries, thereby "logically and implacably" drawing magic and sorcery into the sphere of the Inquisition. ${ }^{9}$ Two of the primary texts of the

\footnotetext{
8 Eugenius IV, Decretal, reprinted in Hansen, Quellen, pp. 17-18.

9 Cf. Peters, The Magician, the Witch, and the Law, pp. 155-6, 160. The two standard general accounts of the late medieval development of inquisitorial literature are Dondaine, "Le Manuel de l'Inquisiteur", passim, and Lea, Materials Toward a History of
} 
fourteenth century which display this feature are the Practica of ficii inquisitoris heretice pravitatis of Bernard Gui and the Diretorium Inquisitorium of Nicholas Eymeric. The Practica, completed sometime between 1323 and 1324, is divided into five parts; the first three provide formulas which regulate the conduct of legal procedures within inquisitorial courts and the fourth consists of a collection of those papal bulls and synodal decrees responsible for setting the limits of inquisitorial power. For our examination of the background to the Malleus Maleficarum it is the fifth section which is most important, the systematic representation of the beliefs and practices of six religiously suspect groups - Manichaeans/Cathars, Waldensians, the "pseudo-Apostles" [i.e. the Fraticelli], the Beguins, the Jews, and sorcerers. The actual discussion of superstitious practices in Chapter Six of Book Five, "De sortilegis et divinis et invocationibus demonum", is excessively brief, Bernard Gui writing well before that period of the extensive elaboration and classification ${ }^{10}$ of malefic

Witchcraft I, pp. 205-20. It is tempting to view the manual's preoccupation with constructing an identifiable object of discourse in relation to the Inquisition's unending quest for political legitimacy; although inquisitors were actively employed in the surveillance of suspect populations from an early date onwards, they were at first largely without any adequate juro-political base with which they could justify their prosecutions of the accused. "Petit à petit cependant s'élaborerent une législation pour fixer les droits et les devoirs des juges religieuses, une jurisprudence pur en ordonner l'application, une procédure pour modérer l'arbitraire des inquisiteurs tout-puissants. Quand à la fin du treizième siècle l'institution atteindra son apogée, la codification de son droit propre sera en voie d'achèvement" Dondaine, "Le Manuel de l'Inquisiteur", p. 85.

$10 \mathrm{Cf}$. Wakefield and Evans, Heresies of the High Middle Ages, p. 767, "Neither the distinction between mere practice of occult arts and actual worship of the devil nor the competence of inquisitorial courts in cases involving the former had been clearly established when Bernard Gui wrote." 
transgression. He does, however, move directly to the essential point, namely the inextricable relationship between superstitious practice and demonic intervention.

Sortilegium et divinationum et invocationum demonum pestis et error varius et multiplex invenitur in diversis terris et regionibus secundum varias adinventiones et falsas informationes vanitatis hominum superstitiosorum intendentium scriptibus erroris et doctrinis demoniorum. ${ }^{11}$

The remainder of the chapter consists of a specific list of questions that should be put to the suspect by the inquisitor - what kind and what number of invocations he knows and from whom he has learned them; whom he has instructed in the art of sorcery; what items are employed in the performance of the sorcery, such as leaden or waxen images; what rituals are performed, especially which involving the Sacraments; and what sort of clientele he enjoys, and what sort of payments and benefits he has received in exchange for his services. 12

The basic taxonomic categories presented in only the most rudimentary form by Bernard Gui are developed in far more comprehensive fashion by Nicholas Eymeric in his Directorium Inquisitorum ${ }^{13}$ of 1376 , the most widely

11 Bernard Gui, Practica Inquisitionis Heretice Pravitatis (Paris, 1886), v, c. 6, p. 292.

12 Cf. ibid., pp. 292-3.

13 Cf. Peters, The Maqician, the Witch, and the Law, p. 196, "Eymeric's remarks upon the topic of magician as heretic are especially important because they formed the basis of most later inquisitorial approaches to the topic." After first being disseminated in manuscript form in 1376, the Directorium underwent at least seven 
disseminated inquisitorial manual from the fourteenth to the seventeenth centuries. The Directorium is divided into three parts, the first two establish the precise nature of the theological relationship between Catholicism and heresy, while the third provides an outline of judicial procedures to be employed against the accused. As with the Practica of ficii, only a small portion of the treatise is of direct concern here, Questions Forty-two and Forty-three of the Second Part, respectively entitled "De Sortilegis et Divinatoribus" and "De invocantibus Daemones". According to Eymeric, diviners and magicians fall into two distinct groups. The first are those who practise purely superstitious and unlearned ritualistic divination, such as chiromancy. The second, more odious, category consists of those heretics who actually proffer the honor of both latria and dulia to demons and perform such rituals as the satanic rebaptism of children. ${ }^{14}$ Central to Eymeric's discussion is the

different editions - 1578, 1585, 1587, 1591, 1595, 1597, and 1607. Cf. ibid., p. 196. I have used the 1595 Venice edition. The publishing history of the treatise deserves comment, as it mirrors that of the Malleus - that is, there was an initial publication followed by a considerable gap to later editions. Presumably the Directorium was subject to the same alterations in demand as the Malleus: the treatsie was reissued to meet the growing need for textual guidance to the hunting of witches in the late sixteenth century.

14 Cf. Eymeric, Directorium Inquisitorum, II, Q. 42, art. 3, p. 336, "Quidam autem alij sunt sortilegi et divinatores non meri, sed ad haereses contracti, ut sunt daemonibus honorem latriae vel duliae impendentes, puerum rebaptizates, vel similia facientes: et hoc pro divinando futura, seu cordis intima penetrando: quae quidem sapiunt haeresim manifeste. Et tales sortilegi et divinatores Inquisitoris indicium non evadunt, sed haereticorum legbus puniuntur, per allegatum c. Accusatus." Latria has been defined as that form of adoration that properly belongs solely to God while dulia is the veneration which should be displayed solely to saints, holy men, and the representatives of the Church. Cf. Peters, The Magician, the Witch, and the Law, p. 202 . 
representation of the demonic magician as belonging to a sort of organized demonic-heretical religious sect. The Directorium raises the question as to whether invokers of demons are subject to the same standards of inquisitorial justice applied to fully fledged heretics; not surprisingly, the text responds af firmatively, as the accused are guilty of an improper form of religious worship of demonic entities.

Inquisitionibus apparet, quidem daemones invocantes, manifeste exhibent honorem latrie demonibus invocatis: utpote eis sacrificando: adorando: orationes exerabiles effundendo: se daemonibus deuouendo; obedientiam promittendo: aliquid se facturos pro daemonibus afferendo: per talem daemonem iurando: per nomen alicuius superioris demonis istum quem invocat adiurando: laudes demonum vel cantus in eius reverentiam promento: genua flectendo: prostrationes faciendo: casitatem pro daemonis reverentia, vel monito observando: ieiunando: vel carnem suam alias macerando: vestibus nigris vel albis pro daemonis reverentia, et artis monito induendo: per characteres et signa, et ignota nomina obsecrando: luminaria accendendo: thurificando: de ambra, ligno aloes, et similibus aromaticis subsumigando: ves, vel animalia alia immolando: sanguinem proprium ex se emittere procurando: aves vel animalia, seu eorum partes comburendo: sal in ignem mittendo: holocaustum de quovis faciendo. Oia.n praedicta, et quam plura alia nefaria in praedictis inveniuntur a daemonibus consultata et concupita; in quibus omnibus, et quolibet praedictorum honor latriae, si predicta bene considerentur, daemonibus exhibetur. Si.n. bene antique et novae legis sacrificia Deo exhibita contemplentur, illico invenietur, qua supradicta non daemonibus, sed Deo sunt solummodo tamquam vera sacrificia exhibenda. Ecce primus modus daemonibus invocandi, vel advocandi. Et isto modo sacerdotes Baal ipsum invocabant, sanguinem proprium et animalia of ferendo, ut legitur 4. Reg. 8. cap. 15 .

If those accused of diabolic latria refuse to either confess or

repent their crimes, or if they relapse into their prior transgressions, they are 
to be punished to the utmost by the secular arm in accordance with the prescriptions of ecclesiastical law concerning heresy. ${ }^{16}$ As this holds for any magical act that involves either an implicit or explicit Pact with demons, which is itself a form of apostasy, similar conditions also apply to those guilty of satanic dulia. ${ }^{17}$ The Directorium strives to defend the veracity of its conclusions by invoking an appeal to three separate forms of authority: the teachings of the saints and doctors of the Church, most notably Augustine and Aquinas; the decisions of canon lawyers; and certain ecclesiastical promulgations, most notably the Canon Episcopi. ${ }^{18}$ Eymeric's usage of the

16 Cf. ibid., II, Q. 43, art. 5, pp. 338-9, "Primus; casus seu conclusio est, que si daemones invocationes exhibeant daemonibus invocatis honorem latriae quoquo modo, et de hoc clare sint convicti iudicialiter vel confessi: tales non ut sortilego, sed ut haeretici iudicio Ecclesiae sunt habendi, et per consequens si respiscant, haeresi pprimitus abiurata, sunt ut penitentes haeretici velle perpetuo immurandi. Si autem noluerint desistere, vel si dixerint se velle desistere, et poenitere, tamen noluerint abiurare; vel si abiurauerint, et postmodum relabantur, saeculari sunt iudicio relinquendi, ultimo supplicio puniendi, per omnia sicut de aliis haereticis iudicant canonicae sanctiones."

17 Cf. ibid., II, Q. 43, art. 11, p. 342, "Secundus casus, seu conclusio est: quod si daemones invocantes non exhibeant daemonibus invocatis honorem latriae, sed exhibeant honorem hiperduliae, vel duliae, modo in antea explicato, et de hoc clare sunt confessi iudicialiter, vel convicti: tales non ut sortilegi, sed ut haeretici iudicio Ecclesiae sunt habendi: et per consequens si resipiscant, errore et haeresi primitus abiurata, sunt perpetuo immutandi ut haeretici penitentes. Si autem non resipiscant, sunt ut impenitentes haeretici feriendi: vel si abiurant, et relabantur, sunt plectendi per omnia sicut caeteri haeretici."

18 Cf. ibid., II, Q. 43, art. 7, p. 339, "Et similiter etiam in aliis operibus magicis, in quibus complementum operis ex virtute demonis expectatur: in omnibus enim est apostasia a fide, propter pactum initium cum daemone: vel verbotenus si invocatio intersit: vel facto aliquo, etiam si sacrificia desint. Non enim potest homo duobus dominis servire, ut dicitur Matth. 8. haec beatus Thomas. Ex his clare patet, quod daemones invocare, et consulere, etiam sine sacrificio, apostasia est a fide, et per consequens haeresis: longe ergo plus cum sacrificio." 
Canon is of decisive importance to his general strategy, as the text is utilized as a means not only of justifying legal penalties but also of identifying heretical magic with diabolism.

Ex his apparet, quod praedictae scleratae mulieres, in perfidia perseverant, a recta via deviant atque fide, et earum mentibus infelidibus demones se obiiciunt et deludunt. Si ergo istae mulieres, de quibus non constat, quod sacrificia offerant daemonibus invocatis, perfidae et infideles, et a recta via deviantes in praefeto decreto in concilia Anquirensi ${ }^{19}$; dictae et habitae sunt; et per consequens, si baptizatae sunt, ut haereticae habendae sunt: quia Christianum a recta via et fide deviare, et infidelitatem recipere, est proprie haereticare: quanto magis Christiani, honorem latriae exhibentes et sacrificantes daemonibus invocatis, dicendi et habendi sunt perfidi, a recta fide devii, et infideles infeliditate Christianorum, quae est heresis; et per consequens haeretici sunt habendi ${ }^{20}$

What is exemplified here is the end result of a subtle blending, over the course of several centuries, of disparate literary genres and discursive formations, producing a gradual blurring of distinctions between the hitherto separate realms of heresy, magic, superstition, and witchcraft. This long-term process of the reappropriation of preestablished literary modes permitted the inquisitorial authorities themselves to engineer the gradual emergence of a new stereotypical category, the diabolic witch, centered around the figure of the traditional village wise woman but infused with certain vital characteristics of both the satanic heretic and the idolatrous magician.

19 I.e. the Canon Episcopi. Throughout the Middle Ages the text was erroneously believed to have derived from the Council of Ancyra of 314. Cf. Russell, Witchcraft in the Middle Ages, p. 76.

20 Eymeric, Directorium Inquisitorum, II, Q. 43, art. 8, p. 341. 
The illustration of this development is best served by a more detailed comparative analysis of the relationship between Aquinas' earlier demonological writings and their subsequent reformulations by late medieval inquisitorial authors. As has already been established, Aquinas' work contained most of the essential features of scholastic demonology - the objective reality of maleficium produced through demonic control over local motion, the necessity of demonic participation in efficacious magical action, the illusory nature of the transformation of human into animal, the reality of human sexual intercourse with incubi or succubi - all formulated in full accordance with Thomas Aquinas' essentially neo-Aristotelian world-view. A case in point was the question of aerial transport via demonic agency. ${ }^{21}$ This explanatory notion was eagerly seized upon by inquisitorial authorities, whose single over-arching purpose appears to have been the thoroughgoing refutation of the (potentially) sceptical conclusions of the Canon Episcopi. ${ }^{22}$ Alphons Tostatus, in his scriptural commentaries composed around 1440, was the first to attempt a logical demonstration of the reality of those night-flying females mentioned in the Canon; in accordance with his Thomistic presuppositions, such women were in

21 In Book Two of the Sententiarum where Aquinas discusses Satan's transportation of Christ to the pinnacle of the Temple in terms of the demonic power to affect local motion. Cf. Aquinas, Sententiarum, II, D. 7, Q. 3, art. 1, p. 25. "For scholasticism the question of men flying though the air by the aid of demons lay under that of the ability of the demons to move bodies locally." Hopkin, The Share of Thomas Aquinas in the Growth of the Witchcraft Delusion, p. 16.

22 Cf. Peters, The Maqician, the Witch, and the Law, p. 150. 
fact demonically empowered. ${ }^{23}$ Striving to refute the objection that the testimonies provided at witchcraft trials are worthless, being the product of diabolic delusion, Peter Mamoris devoted Chapters Five and Six of his Flagellum Maleficorum to demonstrating the reality of demonic control over local motion including that of flight. ${ }^{24}$ And, of course, the Malleus was a major contributor to the discussion. Demonic aerial transport is treated primarily in II, Q. 1, c. 3, [Schmidt, II, pp. 41-53] "De modo, quo localiter transferuntur de loco ad locum", where such power is ascribed to the properties derived from the demon's originally angelic nature.

Primo dicamus de Angelis. Nam minimus Angelus omnem humanam virtutem incomparabiliter excedit. Rationes summuntur ex pluribus. Primo, quia virtus spiritualis fortior virtute corporali, sicut virtus Angeli, aut etiam animae superior quam virtus corporalis. Secundo quoad animum: Quia cum omnis forma corporalis est forms individua per materiam, et determinata per haec, et nunc prout iam anima nostra existit: formae autem immateriales sunt absolutae et intelligibiles. Unde etiam potestam habent absolutam, et universaliorem. Ideo anima coniuncta non potest ita subito transferre corpus suum localiter, nec in altum elevare. Bene autem faceret, cum esset separata, Deo permittente: quae omnia a fortiori potest spiritus omnino immaterialis: prout est Angelus tam bonus, quam malus. Sicut etiam Angelus bonus

23 Tostatus, "Bibelkommentar", reprinted in Hansen, Quellen, pp. 105-9, "Ad primum in contrarium dicendum, quod ibi non negatur, quin mulieres possint portari a daemonibus per noctem et diversa spatia pretansire, sed vetatur credi totum illud, quod ipse asserunt, scilicet, quod ambulant cum Herodiade vel Diana dea paganorum, et credunt illam esse deam, sicut apud paganos pluralites deorum tenebatur. Dicere ergo, Dianam illam esse deam, non solum est error, sed infidelitas. Et patet, quod ista sit intentio literae, quia quando ibi accusatur iste error, dicitur quod multitudo innumera, hac falsa opinione decepta, haec vera esse credunt et credendo a recta fide deviant et errore paganorum involvuntur, cum aliquid divinitatis aut numinis extra unum deum arbitrantur. Sunt autem daemones ista Diana et Herodius, quae se in forms dearum venerari faciunt." Ibid., p. 107.

24 Mamoris, Flagellum Maleficorum, c. 5-6 [unpaginated]. 
transtulit Abachuc in momento a Indeae in Chaldeam. Et ex hac ratione etiam concluditur, quod illi qui de nocte in somnis per alta aedificia vehuntur, non feruntur a propriis animalibus, nec ex influentis corporum coelestium, sed ab aliqua excellentiori virtute. ${ }^{25}$

These considerations are then employed against those who would foolishly adhere

to a literal understanding of the Canon Episcopi.

Nec argumenta etiam a principio adducta eis suffragari possunt. Nam primum cum allegant capitulum Episcopi 26, q. 5. Ubi afferitur, quod tantum phantastice et imaginarie transferantur, quis tam insipiens, qui velit concludere, quod non possint etiam corporaliter transferre. Sicut enim ex fine illius capituli, ubi ponitur, quod qui credit posse hominem in melius vel in deterius transmutari, aut in aliam speciem transformari, infideli et pagano deterior fit censendus: quis possit concludere quod non possint homines in bestias praestigiosa illusione transformari, aut etiam de sanitate in infirmitates tanquam meliori in deterius transmutari. Iam talis, qui sic in cortice verborum canonis laboraret, utique contra mentem omnium Doctorum Sanctorum, imo et contra Scripturae Sacrae processum sentiret.

Ex quibus multipliciter oppositum apparet, ut ex supradictis in plerisque locis circa primam partem tractatus deductum est. Oportet ergo ad nucleum verborum attendere, iuxta quod in prima quaestione primae partis tractatus tactum est hoc cir a solutionem secundi erroris inter tres, qui ibi reprobantur: quod quatuor iniunguntur praedicatoribus populo ad praedicandum, transferuntur enim et corporaliter, et phantastice. Iuxta quod ex earum propriis confessionibus patet, non tam illarum quae incineratae fuerunt, quam etiam aliarum, quae ad fidem et poenitentium redierunt. $^{26}$

Although Thomas' demonology provided both direct and indirect

support for the witchcraft ideology developed by later inquisitorial authorities

there is an element of ambivalence in the ways in which certain features of his system were used to elaborate what Norman Cohn has labelled the "non-existent

25 Malleus, II, Q. 1, c. 3, pp. 113-14 [Schmidt, II, pp. 47-8].

26 Ibid., II, Q. 1, c. 3, p. 115 [Schmidt, II, pp. 51-2]. 
society of witches", with its defining characteristics of the demonic Pact and the satanic Sabbat. ${ }^{27}$ While it is true that Aquinas declared the magician's Pact with the devil to constitute a form of apostasy ${ }^{28}$, there is absolutely nothing within his demonology to indicate his credence in the reality of the Sabbat, the ritualistic act of homage performed by the witch to honor Satan. $^{29}$ A particularly striking example of this mutation of Thomistic doctrine is to be found in the aforementioned Q. 1, c.3 of the Second Part of the Malleus; although the basic explanatory principles of demonic transport are in accordance with Aquinas' views, the description of the ritual operations performed by the witch to engender such effects is not.

Modus autem transferendi talis est: Nam ut ex praecedentibus patuit, unguentum ex membris puerorum, praecipue interemptorum ab eis ante baptismum conficere habent ad Daemonis instructionem, sedile aliquod, aut lignum inungere, quo facto, statium in aera feruntur, et hos sive de

27 Cohn, Europe's Inner Demons, ch. 6, passim. Cf. also Hopkin, The Share of Thomas Aquinas in the Growth of the Witchcraft Delusion, pp. 179-80, "It is clear that Thomas, directly or indirectly, afforded both explanation and support for the witchcraft delusion in most of its important features, and that his themes were extended to give credance to others. On the other hand, it is equally plain that, saving the demonology of the Church, Thomas' own interests lay in a different direction from that of witchcraft and that his demonology was certainly no more appropriate, in some details less appropriate, to the delusion than was the demonism of the ancient tradition."

\footnotetext{
28 Cf. Aquinas, Sententiarum, II, D. 7, Q. 3, art. 2, p. 25.

29 "The general tone of Thomas Aquinas' demonology is far removed from that of the witchcraft literature [...] even in his discussion of demons, Thomas makes all derive from God and depend upon God. With the exception of some passages in his commentary on the Book of Job, one can read Thomas' demonology throughout without once encountering a gloomy atmosphere in which the forces of evil predominate. The demons are outnumbered by the good angels and the Christian has an adequate defense." Hopkin, The Share of Thomas Aquinas in the Growth of the
} Witchcraft Delusion, p. 176. 
die, sive nocte, visibiliter, seu etiam, si id volunt invisibiliter, secundum quod Daemon et obstaculum alicuius corporis, alterum corpus occultare potest, ut in prima parte tractatus, de praestigiosa apparatione operum Daemonum patuit. Verum licet Daemon per tale unguentum, ut plurimum huiusmodi practicat, in finem, ut baptismi gratia infantes privet et salvatioe, tamen et absque his pluries ef ficere visus est ubi per animalia, quae utique non animalia vera, sed Daemones sub formis illis existentes, ipsas transvexerunt: aut etiam aliquo sine exteriori adminiculo solummodo Daemonis virtute visibiliter operante, interdum transferuntur. 30

Two separate, albeit interactive, long-term processes lay behind this

development. The first was the notion of the Pact as a necessary prerequisite for the occurrence of demonic magic ${ }^{31}$, an idea which received its earliest authoritative formulation from St. Augustine's in De Doctrina Christiana.

Vel ad consultationes et pacta quaedam significationum cum daemonibus placita atque foederata, qualia sunt molimina magicarum artium ... Ad hoc genus partinent omnes etiam ligaturae atque remedia, quae medicorum quoque disciplina condemnat, sive in praecantationibus, sive in quibusdam motis quos characteres vocant, sive in quibus que rebus suspendendis atque, illigandis vel etiam aptandis quodammodo, non ad temperationem corporum, sed ad quasdam significationes aut occultas, aut etiam manifestas ${ }^{32}$ [...] Omnes igitur artes huiusmodi vel nugatorie vel noxiae supersitionis, ex quadam pestifera societate hominum et daemonum, quasi pacta quaedam infidelis et dolosae amicitiae constituta, penitus sunt repudianda et fugienda christiano. 33

30 Malleus, II, Q. 1, c. 3, p. 114 [Schmidt, II, p. 49].

31 Cf. Russell, Witchcraft in the Middle Ages, p. 144, "The chief means of uniting sorcery [i.e. ritual magic] and witchcraft was the idea of the pact."

32 Augustine, De Doctrina Christiana, (Vindobonae, 1963), II, C. 20, pp. 55-6.

33 Ibid., II, C. 23, pp. 59-60. Cf. Lea, Materials Toward a History of Witchcraft, I, p. 200, "This passage became the locus classicus on the subject." However, as Richard Kieckhefer has pointed out, within later medieval demonology: "The pact [...] is not so much the written agreement as the act of submission on the part of the 
Such beliefs were also manifest on the popular level, as is attested by the longstanding popularity of the story of Theophilus. ${ }^{34}$ Similar notions continued throughout the medieval period, the belief in the demonic Pact as an indispensable component of (idolatrous) magic receiving its most notorious expressions in the writing of Caesarius Heisterbach ${ }^{35}$ and, somewhat later on, in the gestation of the Faust legend. ${ }^{36}$ The promulgation of the Conclusio of the University of Paris may be taken as the indicator of the establishment of an irreversible trend; the necessity of demonic intervention in magical operations demanded, in turn, the postulation of some form of personal and/or contractual relationship between magician and demon. As witchcraft was by this time defined as a form of superstition - and, by extension, a form of heresy akin to idolatrous magic - so was it deemed a logical imperative to view the witch as the vassal of a satanic master.

witch." Kieckhefer, European Witch Trials, p. 87.

34 Cf. Cohn, Europe's Inner Demons, pp. 233-4; Roos, The Devil in Sixteenth-Century German Literature: The Teufelsbücher, ch. 4, passim; Cf. also Kieckhefer, European Witch Trials, p. 86, "It is important [...] to recognize the prime significance of the pact as a means of placing the devil at the service of the witch, so that the witch's desires might be carried out with almost mechanical regularity by the devil."

$35 \mathrm{Cf}$. in this regard especially the anecdote concerning the knight and the magician provided in Caesarius Heisterbach, The Dialogue on Miracles, (London, 1929), I, Book Five, c. 1-2, pp. 313-17.

36 Cf. Roos, The Devil in Sixteenth-Century German Literature: The Teufelsbücher, ch. 4, passim. 
The second process, which was eventually to draw heavily from the first, was the diabolisation of the heretical sects. ${ }^{37}$ The literature in this genre is vast and far excels the boundaries of this dissertation. Yet a few selected texts that were influential as the backdrop of the emergence of the Malleus shall be discussed. One such example, Bernard Gui, provides an account of Waldensian devotional practices with decidedly satanic overtones.

Sciendum quoque est quod predicta secta multos alios errores ab olim habuit, et tenuit, et adhuc in aliquibus partibus habere dicitur in secreto, sicut de celebratione misse in die Cene, sicut dictum est superius, et de mixto, abhominabili in tenebris faciendo qualibet cum qualibet indistincte, et de apparatione cati et aspersione cum cauda, et de quibusdam aliis que in summulis super hoc conscriptis lacius continentur. 38

Such trends continued well into the fifteenth century. The depiction of Catharist religious services in the anonymous Errores Gazariorum of 1450 presents the heretics performing a parody-like inversion of Christian services in which worship of the devil, the author of heresy, is inextricable from sociosexual perversity. 39 The Waldensians were the victims of repeated assault,

${ }^{37}$ See above, Chapter One. Cf. also Cohn, Europe's Inner Demons, chs. $2-3$.

38 Bernard Gui, Practica Inquisitionis, v, c. 2, art. 4, p. 248.

39 Cf. Errores Gazariorum, reprinted in Hansen, Quellen, pp. 11822. Cf. ibid., pp. 118-9, "Primo quando aliqua persona cuiusvis sexus per aliquem, humane nature inimico suadente, seducitur, seducens in abissum malorum seductum precipitans facit ipsum jurare totiens quotiens fuerit per ipsum requisitus, omnibus pretermissis secum ad synagogam properabit, attento quod dictus seducens unguenta ad hoc pertinentia et baculum debebat ministrare, prout facit.

Item i psis existentibus in loco synagoge, seducens diabolo, rationabilis creature inimico, seductum presentare stagit. Qui quidem inimicus apparet aliquando in specie cati nigri, aliquando in specie hominis non tamen perfecti vel sub similitudine alterius animalis, sed 
subjected to satanic representation in the Recollectio of the Valdenses ydolatrae $^{40}$, the Tractatus de secta Vaudensium of Johannes Tinctoris ${ }^{41}$, and the anonymous account of Waldensian activities in the vicinity of Lyon. ${ }^{42}$ In all these accounts, certain basic features remain constant - the heretics gather periodically at organized Sabbats to pledge their allegiance to Satan, and such Sabbats, or synagogues 43 , were accompanied by acts of horrendous social deviancy. The heretic is no mere criminal transgressor; he is an active member of an anti-Christian underground religious movement.

ut communiter sub similitudine cati nigri; quo seducto per diabolum interrogato, an velit in societate permanere et persistere ad nutum seducentis, respondet, quod sic; quo audito diabolus iuramentum fidelitatis a seducto exigit in modum, qui sequitur: primo iurat, quod erit fidelis magistro presidenti totique societati; secundo quod omnes, quos poterit societati agregare, pro posse agregabit; tertio quod usque ad mortem non revelabit secreta predicte secte; quarto, quod omnes pueros, quos potent stringere pariter et interficere, interficiet et ad synagogam deportabit, et intelligitur de pueris trium annnorum et minori etate constitutis; quinto quia totiens quotiens fuerit vocatus ad synagogum omnibus postpositis festinabit venire; sexto quod omnia matrimonia, que poterit impedire, pro posse impediet per sortilegia et alia maleficia; septimo quod vindicabit iniurias secte vel alicui ex ipsis factas coniunctim vel divisim." The derivative term for Cathar, gazarus, also served as a widespread appellation for "witch" throughout the fourteenth and fifteenth centuries; cf. Russell, Witchcraft in the Middle Ages, p. 317.

40 Reprinted in Hansen, Quellen, pp. 149-83.

41 Tinctoris, Tractatus de secta Vaudensium, reprinted in Hansen, Quellen, pp. 183-8.

42 "La Vaudenge de Lyonis en brief", reprinted in Hansen, Quellen, pp. 188-95.

43 Throughout the fifteenth century, the term "synagogue" was preferred by inquisitors, presumably because of its greater antisemitic connotations. The word "Sabbat" was only used by two authorities prior to the Malleus, Peter Mamoris and Jean Vincent in his Liber adversus maqicas artes. Cf. Russell, witchcraft in the Middle Ages, p. 238. 
It is easy to discern how two disparate concepts, the demonic Pact and the heretical Sabbat, could gradually be fused together and manipulated by zealous inquisitorial authorities. All magical or superstitious practice demanded demonic participation to prove efficacious, which in turn demanded a personal commitment of the magician to the devil; heresy, of which superstitio and divinatio were sub-categories, involved the ritualistic worship of Satan accompanied by mandatory acts of socio-sexual transgression - hence, the witch, as superstitious practitioner, as magician, as heretic, had to be guilty of the same of fences, if not indeed identical with that entire category of religious deviant as such. ${ }^{44}$ It is precisely this process of conflicting literary stereotypes which can be discerned at work in the very earliest inquisitorial witchcraft manuals of the fifteenth century.

The Flagellum Haereticorum Fascinariorum of Nicholas Jacquier, composed in 1458 , is a particularly good example of these developments that finally led to the composition of the Malleus Maleficarum. The main purpose of the text is to refute sceptical objections against witchcraft confessions made on the grounds that such reported phenomena are the result of demonic illusion. 45 Accordingly, the greater part of the treatises's twenty-eight chapters are devoted to an examination of the various forms of illusions demons

44 Cf. ibid., p. 241, "To be a witch rather than a sorcerer, one had not only to invoke, but also to worship, the Devil."

45 Cf. Hopkin's discussion of the issue in The Share of Thomas Aquinas in the Growth of the Witchcraft Delusion, pp. 161-2. 
are capable of generating. Chapter Six, for example, expounds upon the Thomistic notion that demons can effect physical transformation through their control over local motion and, thus, are able to manipulate both passions and ideas through the resultant fantasies. ${ }^{46}$ Most important in this respect is the text's linkage of demonic action with the heretical worship of the devil by witches. In language and imagery reminiscent of the Errores Gazariorum, malefici are no longer merely superstitious, but the sworn enemies of God.

In quorum veneratione summum et verum deum cum verbis blasphemis expresse abnegant et eius susceptam prius fidem ab eade, apostando, qui praeterea sunt sacrae cruci domini nostri Jesu Christi et aliorum divinorum ministeriorum impudentes prophanatores et conculcatores et crudeles maleficorum perpetrationes ac scandalizationes ac perturbatores fidelium caeterorum. 47

In Chapter Seven ${ }^{48}$, Jacquier provides extensive proof of the reality of both malefic congregations and malefic power, while simultaneously undermining the sceptical attitude of the Canon Episcopi. Such a dual strategy is accomplished by presenting the satanic synagogue as being that locale to which nocturnally aloft witches are transported.

Tunc enim praedicti seductores fascinarii callide talibus personis aperiunt et of ferunt modum ad complendum sua desideria et ad satisfaciendum suis affectionibus per medium et cultum ipsius haeresis et sectae. Quibus

46 Cf. Nicholas Jacquier, Flagellum Haereticorum (1581), c. 6, "Quod corpora a Daemonibus formata et assumpta non sunt viva, licet sint sensibus exterioribus perceptibilia", pp. 30-6.

47 Ibid., "Praefatio Ad Lectorum".

48 Cf. Ibid., "De Differentia Inter Sectam et Haeresin fascinariorum modernorum, et illusionem mulierum de quibus loquittur c. Epsicopi", pp. 36-51. 
consentientibus, ducunt huiusmodi personas ad locum conventionis fascinariorum certo et statuto tempore, et demonibus ibidem presentant, instruendo eos, ne quovis modo in ipsa congregatione signum crucis faciant vel de deo loquantur, nisi vituperando, scilicet ipsum abnegando. Et postquam ibidem praedictas personas colligaverunt cum daemone, inde reducant eas et associant, tam eundo quam redeundo. Compertumque est, quod huiusmodi seductores multis diebus et importuna sollicitudine operam dederunt ad hoc, ut quasdam personas ad dictum sectam et diabolicam synagogam deduxerunt. Contigit etiam quandoqu, quod hi, qui ad locum synagogae diabolocae fuerunt ducti ad praesentiam demonum, caute propter pristinam consuetudienm fecerunt signum crucis, unde demones abscedebant et evanescebant, et dissipabatur synagoga et inde a suis seductoribus fuerunt graviter reprehensi super hoc, quod signum crucis fecerunt et impediverunt perfectionem cultus vel celebrationem synagoge diabolicae. Ex quo manifeste patet, quod haec fiunt corporaliter, vigilando. Unde differt haec secta ab illa, de qua fit mentio in praedicto capitulo Episcopi, ubi nil tale contigit. ${ }^{49}$

After describing in rather graphic detail the rituals of the synagogue provided

to the author, allegedly on the basis of a personal testimony 50 , the text goes on to situate the reality of both the Sabbat and nocturnal flight within the context of the intellectual dispute bequeathed by the Canon.

Secundi hos idem patet ex parte daemonum huius sectae actorum et operationum inde provenientium. In ea enim fantastica apparaione sive illusoria congregatione, de qua fit mentio in saepedicto capitulo Episcopi, nil aliud habetur, nisi quod quaedam mulieres illusae putabant se ire in obsequium Diana vel Herodiadis, quae sunt fabulosae quaedam et poëticae fictiones. In hac autem fascinariorum secta sive synagoga conveniunt non solum mulieres, sed viri, et quod deterius est, etiam ecclesiastici et religiosi, qui stant et loquuntur cum daemonibus perceptibiliter, inter eos apparentibus variis formis, et a quibus daemones faciunt se nominari propriis nominibus, quos ipsi fascinarii genibus flexis et osculis exhibitis adorant et colunt, recipiendo eos in dominos et magistros, abnegando deum et fidem catholicam et fidei mysteria, quibus daemones ipsi

49 Ibid., c. 7, pp. 38-9.

50 Cf. ibid., c. 7, pp. 39-41. 
promittunt patrocinia et auxilia, cum ab eis invocantur, quibus etiam ipsi demones postmodum ab eis invocati apparent quandoque de die et in aliis locis, quandoque in synagoga, et eis suffragantur frequenter ad nutum, quibus etiam ipsi daemones dant veneficia et materias ad maleficia perpetranda. Quae quidem materiae veneficae frequenter sunt ab aliis repertae et visae. Nihil autem horum contigit in illa fantastica congregatione et illusoria Dianae associatione, unde fit mentio in capituli Episcopi. Putet igitur, longam esse differentium inter hanc fascinariorum sectam realemque isporum cum daemonibus communicationem et illam fantasticam mulierum dormientium illusionem. 51

The Flagellum makes it abundantly clear that the magical potency of witches

is not only derived from but dependent upon that act of homage which they

display to Lucifer at the synagogic congregation.

Est manifestum ex perpetratione innumerabilion maleficiorum, quae fascinarii perpetrant daemonum patrocinio, quod ipsi realem communicationem pactionemque est confoederationem habent cum daemonibus. Hi namque malefici facinarii, conscii et quodammodo certi de daemonum promisso patrocinio, frequenter his, quibus indignantur, inferunt comminationes de nocumentis et quandoque prefigentes terminum futurarum nocumentorum et quandoque experimentes qualitatem nocumentorum infra terminum praefixum. Quandoque vero ab ipsis contingentibus nocumentis ipsi malefici fascinarii liberant patientes nocumenta, inducti precibus vel coacti terroribus et quandoque verberibus. Nec apparet aliquis modus naturalis vel artificialis predicta maleficia sive nocumenta inferendi vel auferendi. 52

51 Ibid., c. 7, pp. 41-2.

52 Ibid., c. 7, pp. 42-3. The passage continues: "Ex processibus praedictis eorundemque fascinariorum confessionibus et factis evidenter patet, eos inferre sive procurare infirmitates, languores, furias, impedimenta circa coniugia, mortes tam hominum quam pecorum, absorsus conceptivam et impedimenta conceptionum et frugum et plurium rerum temporalium vastitiones. Cum igitur praedicta maleficia daemonum invocatione et patrocinio contingentia sint reales, et mali fructus maleficorum fascinariorum cultorum et sectae et haeresis praedictae, clarum est, quod realiter et non fantastice praedicti haeretici fascinarii confoederati sunt cum daemonibus et eos colunt obsequunturque eorumque sunagogas frequentant, in quibus daemones cum eis perceptibiliter assistant." Ibid., c. 7, pp. 43-4. 
Upon the basis of this brief survey of the Flagellum, it is possible to extrapolate some partial conclusions. Through the efforts of inquisitorial authors such as Jacquier, the essential elements of the witchcraft ideology were in place by the middle of the fifteenth century. The diabolic origin of the illusion of shape-shifting, demonic and aerial transport - both the illusory as well as the objective result of actual physical contact-, the bonae mulieres of the witches themselves, the kidnapping, ritualistic murder, and pedophagiac consumption, sexual orgies, nocturnal gatherings at a Sabbat or synagogue, of ten involving the desecration of the Host or other Sacraments; and the establishment of a Pact, either tacit of open, between witch and demon - all of these had emerged as the crucial distinguishing features of a mode of stereotypical literary representation of a particular category of religious deviancy. 53 The need thus naturally arose for a simple text to unify these disparate characteristics into a grand synthetic summation.

Although an important item of concern within the Malleus, the text's failure to provide detailed accounts of the actual proceedings of the Sabbat have led some commentators to disparage the text's importance in the historical development of witchcraft literature. ${ }^{54}$ It is easy to see why such a view is

53 Cf. Russell, Witchcraft in the Middle Ages, pp. 234-42.

54 Cf. Cohn, Europe's Inner Demons, p. 225, "The importance of the most famous of the witch-hunters' manuals, the Malleus Maleficarum, published in 1486 [sic], has been exaggerated [...] The Malleus has little to say about the witches' sabbat or about nocturnal flying, but both figure prominently in records of trials from the $1420 \mathrm{~s}$ and $1430 \mathrm{~s}$ onwards." 
mistaken. The operational method of the text is based on the attempt to provide a coherent theological rationalization of maleficium so as to render it assimilable to the total discursive framework concerning heresy and diabolism. What is of primary importance is not what witches actually do, but rather that what they do can be classified in a particular fashion, in this instance, to define the witch as a particular object of knowledge - the diabolic-heretic - and to subject her to a particular set of ecclesiastical disciplinary mechanisms. What is crucial is that the actions of the witch can be presented as being essentially identical with those of the Heretic-Magician. ${ }^{55}$ Such an identification is achieved through placing both the witch and the magician in the same relationship to Satan via the Pact.

Nam attento quod haec haeresis Maleficorum, non solum differt ab aliis haeresibus in hoc quod ipsa per pacta, nedum expressa, verum etiam placita ac foederata, in omnem creatoris, ac suarum creaturarum contumeliam et nocumentum in sanit: cum tamen omnes alie simplices haereses per nullum pactum tacitum vel expressum, cum Daemonibus initum licet non absque instincta satoris omnis invidiae erroribus propter difficultatem credendorum assentuit. Verumetiam differt ab omni noxia et superstitiosa arte, in hoc quod super omnia genera divinationum ipsa Maleficorum haeresis supremum obtinet gradum malitiae, quod etiam nomen a maleficiendo seu male de fide sentiendo sibi usurpat, ut prius

55 The text is adamant to stress the physical reality of the Pact. "NeC iterum per quodcunque pactum, quocunque modo per aliquod sacrificium alicuius animalis, seu sacrilegae deprecationis, aut cultur etiam latriae exhibitionis, sed se ipsas in anima, et corpore Daemonibus offerentes, fidem penitus sacrilego ore abnegantes. Nec his contentae, etiam proprios aut alienos infantes Daemonibus offerunt, aut interimunt, de quibus supra habitum est." Malleus, I, Q. 16, p. 86 [Schmidt, I, p. 200]. 
tactum est. 56

Attento etiam, quod inter alios actus habent pro augmento illius perfidiae quatuor exercare, videlicet fidem Catholicum in toto, vel in parte ore sacrilego abnegare, seipsos in corpore et anima devouere, infantes nondum renatos ipsi maligno of ferre, spurcitijs diabolicis per carnales actus cum Incubus et Succubis Daemonibus insistere. 57

Although the Malleus fails to discuss the fourth requirement - all of the text's discussions of human-demonic sexual intercourse fail explicitly to relate it to the ritualistic worship of Satan ${ }^{58}$ - it is true that the notions of both the Pact and the Sabbat serve as an important means of rendering coherent disparate aspects of maleficia.

One such means involves employing the existence of the Sabbat as a means of guaranteeing the reality of nocturnal flight. Institoris claims he had received first-hand confirmation of the reality of both phenomena from a young

56 This point relates to the notion concerning the greater capacity of witches to inflict material harm. For this reason diabolic midwifery is held to be the worst form of maleficium because it involves the slaughter or degradation of unbaptized children. See below.

57 Ibid., I, Q. 2, p. 17 [Schmidt, I, pp. 38-9].

58 Cf. ibid., I, Q. 3 [Schmidt, I, pp. 41-56]; I. Q. 4 [Schmidt, I, pp. 56-64]; I, Q. 6 [Schmidt, I, pp. 92-109]; II, Q. 1, c. 4 [Schmidt, II, pp. 53-9]; II, Q. 2, c. 1 [Schmidt, II, pp. 197-206]. One possible explanation for this puzzling feature of the text relates to an inherent difference between witchcraft and heresy. The depiction of heresy in inquisitorial literature is that of a communal activity, with mass participation in satanic adoration and the accompanying sexual depravity. The Malleus, however, portrays maleficium as a private crime, witches engaging in isolated acts of carnality with individual incubi or succubi. The text's omission of reports of malefic orgies would thus seem to be one result of the Malleus's comparatively undeveloped notion of the Sabbat; the notion of the communal sexual licentiousness of witches would only arise at a later point in the history of the development of witchcraft literature with the more systematic - and grandiose - fusion of the symbolism of heretical and malefic deviancy. 
tactum est. 56

Attento etiam, quod inter alios actus habent pro augmento illius perfidiae quatuor exercare, videlicet fidem Catholicum in toto, vel in parte ore sacrilego abnegare, seipsos in corpore et anima devouere, infantes nondum renatos ipsi maligno of ferre, spurcitijs diabolicis per carnales actus cum Incubus et Succubis Daemonibus insistere. ${ }^{57}$

Although the Malleus fails to discuss the fourth requirement - all of the text's discussions of human-demonic sexual intercourse fail explicitly to relate it to the ritualistic worship of Satan 58 - it is true that the notions of both the Pact and the Sabbat serve as an important means of rendering coherent disparate aspects of maleficia.

One such means involves employing the existence of the Sabbat as a means of guaranteeing the reality of nocturnal flight. Institoris claims he had received first-hand confirmation of the reality of both phenomena from a young

56 This point relates to the notion concerning the greater capacity of witches to inflict material harm. For this reason diabolic midwifery is held to be the worst form of maleficium because it involves the slaughter or degradation of unbaptized children. See below.

57 Ibid., I, Q. 2, p. 17 [Schmidt, I, pp. 38-9].

58 Cf. ibid., I, Q. 3 [Schmidt, I, pp. 41-56]; I. Q.4 [Schmidt, I, pp. 56-64]; I, Q. 6 [Schmidt, I, pp. 92-109]; II, Q. 1, C. 4 [Schmidt, II, pp. 53-9]; II, Q. 2, c. 1 [Schmidt, II, pp. 197-206]. One possible explanation for this puzzling feature of the text relates to an inherent difference between witchcraft and heresy. The depiction of heresy in inquisitorial literature is that of a communal activity, with mass participation in satanic adoration and the accompanying sexual depravity. The Malleus, however, portrays maleficium as a private crime, witches engaging in isolated acts of carnality with individual incubi or succubi. The text's omission of reports of malefic orgies would thus seem to be one result of the Malleus's comparatively undeveloped notion of the Sabbat; the notion of the communal sexual licentiousness of witches would only arise at a later point in the history of the development of witchcraft literature with the more systematic - and grandiose - fusion of the symbolism of heretical and malefic deviancy. 
servant-girl that he had reputedly interrogated in Breisach.

Hunc modum [of initiation into the Devil's service - see below] nos inquisitores (experientia teste) percepimus in oppido Brisaco Basilensis diocesisi plenam informationem apiendo zab una iuvencula maleficia, sed conversa cuius et matertera in diocesi Argentinensi incinerata fuerat, quae etiam addiderat quod postmodum, quo eius matertera ipsam primitus seducere tentasset, talis erat. ${ }^{59}$ [...] Asservit etiam quod saepius per longa terrarum spatia, de nocte secum translata fuerat, etiam ab Argentina usque Coloniam. 60

The servant-girl's account serves as the main basis for the discussion of

nocturnal flight provided in II, Q. 1, c. 2, p. 106 [Schmidt, II, p. 30].

Haec et illa cuius occasione in prima queatione praemissum est ${ }^{61}$, nos velle declarare, an Maleficae vere et corporaliter a Daemonibus transferantur de loco ad locum: et hoc propter verba Canonis 6. [sic] $\mathrm{q}_{\text {. }}$ 5. Episcopi, ubi textus sentit quod solummodo imaginarie, cum tamen interdum etiam vere et corporaliter transferantur.

Interrogata enim an solum imaginari et phantastice sic incederent per Daemones illusae. Respondit quod utroque modo: prout etiam veritas se

59 See above, Chapter Four.

60 Ibid., II, Q. 1, c. 2, p. 106 [Schmidt, II, pp. 29-30].

61 "Nam si corporaliter, ut supra tactum est [The reference is unclear. Perhaps it simply refers to the aforementioned fact, discussed in Malleus, I, $Q .1$, that witches do enjoy the faculty of aerial transport.], nolunt transferre, sed tantum imaginarie cerner, quae a consodalibus maleficiis perpetrantur, reponere se habent ad sinistrum latus in nomine sui Diaboli et omnium Daemoniorum. Unde sit, ut eis singula imaginaria visione repraesententur a simili. Si aliqua occulta scire pro se vel aliis hominibus volunt a Daemonibus, per somnia instruuntur, non per tacita, sed per expressa cum eis pacta inita." Ibid., I, Q. 16, p. 86 [Schmidt, I, p. 200]. A similar account is provided in II, Q. 1, c. 3, p. 115 [Schmidt, II, p. 52], "Inter quas et illa in oppido Brisiaco interrogata a nobis, an ne phantastice et illusorie aut corporaliter possent transferri: respondit quod utroque modo. Si enim casu aloquo nollent corporaliter transferri, scire tamen vellent omnia quae in concione illa ab earum consodalibus agerentur, tunc talis ab eis servaretur modus, ut illa in nomine omnium Diabolorum ad latus sinistrum se reponeret ad cubitum: ex tunc quasi vapor quidam glaucus ex eius ore procederet. Unde singula quae ibi agerentur perlucide considerarent, si vero corporaliter transferri vellent, modum supradictum servare necesse esset." 
habet, ut inferius de modo transferendi localiter declarabitur.

With this exemplary passage, the Malleus is able to accomplish a number of objectives simultaneously. It provides further evidence for the reality of demonic flight, thereby refuting the sceptical objections which could be derived from the Canon Episcopi, while at the same time providing a partial vindication of the "flight-as-illusion" hypothesis, thereby managing to avoid directly undermining the episcopal authority inherent within the Canon; it establishes nocturnal flight as an indicator of demonic phenomena and, by extension, of the diabolic nature of the witch; it offers proof of the reality of the Pact and its role as a signifier of satanic witchcraft; and it ascribes to the witch those forms of social transgression which brand her a heretic.

The servant-girl is utilized as an authority not only upon the nature and reality of demonic flight but also upon the accompanying social transgressions of the witches themselves. The greatest of these concern the witch in her capacity as an infanticidal midwife.

Asservit etiam quod maiora damna ab obstetricibus inferuntur, quia ut plurimum infantes, aut habent interimere: aut Daemonibus of fere, ab ipsa etiam matertera asservit se graviter fuisse verberatum, eo quod ollam quandam occultatem discooperiendo plurimorum infantium capita reperisset. Et plura alia retulit orius praestito pro dicenda veritate iuramento, aut decuit. 62

The theme of the malefic midwife is developed in greater detail in $I, Q .11$ [Schmidt, I, pp. 157-9], "Quod obstetrices Maleficiae, conceptus in utero diversis

62 Ibid., II, Q. 1, c. 2, p. 106 [Schmidt, II, pp. 30-1]. 
modis interimunt, absorum procurant, et ubi hoc non faciunt Daemonibus natos infantes of ferunt." 63 This question may be best viewed within the context of the Malleus's larger strategy of linking maleficia with femininity; "Quae cum per mulieres Daemones exercere habent et non per viros, ideo potius mulieres quam viros, ideo potius mulieres quam viros sibi associare ille homicida satagit." 64

The text recognizes that there are a number of purely natural means of either preventing conception or inducing abortion, e.g. through herbal substances. What distinguishes diabolic midwives is that they frequently resort to infanticide if they have failed to affect a miscarriage, of ten devouring the child's corpse afterwards. The Malleus provides some empirical evidence to verify this claim.

Certae Maleficae contra humanae naturae inclinationem, imo adversus ominum bestiarum conditiones, lupina, duntaxat specie excepta infantes devorare, et comedere solent. Est Inquisitor Cumanus ${ }^{65}$, de quo supra mentio habita est, qui haec nobis retulit, quod ea de causa ab incolis Comitatus Burbiae vocatus ad inquisitionem faciendam, eo videlicet, quod quidam cum puerum ex cunis amisisset, et explorando conventionem mulierum nocturno tempore vidisset et perpendisset infantem occidi, et liquore ebibito devorare. Ideo, ut prius tactum est, unico anno qui et fuit annus proxime elapsus, quadraginta et unum maleficam igni tradidit, certis aliis ad Dominum Archiducam Austriae Sigismundum fugam

63 An extended discussion concerning midwife as witch is also provided in Malleus, II, Q. 1, c. 13 [Schmidt, II, pp. 135-46], but there is no direct reference to either the pact or the sabbat.

64 Ibid., I, Q. 11, p. 68 [Schmidt, I, p. 157]. See above, Chapter Three.

65 See above, Chapter Three. 
capientibus. 66

The chapter ends on a suitably dire note, proclaiming the grievous peril posed by diabolic midwives and establishing a connection between such a menace and the heretical worship of Satan.

Sed et hoc, quod maiora damna in his omnibus obstetrices Maleficae procurant, prout Maleficae penitentes nobis et aliis saepius, retulerunt, dicentes, Nemo fidei catholicae amplius nocet, quam obstetrices: Ubi enim pueros non interimunt, tunc quasi aliquid acturae foris extra cameram infantes deferunt, sursum in aëre elevantes, Daemonibus of ferunt. ${ }^{67}$

Many of these themes are developed in greater detail - and with

considerably more elaborate theological speculation - in II, Q. 1, c. 13 [Schmidt, II, 135-46]. ${ }^{68}$ The theological implications of the anti-social behaviour of witches are inextricable from the debate on the issue of infant perdition.

Qua autem de causa utique praesumendum quod ad instantiam malignorum spirituum etiam eis interdum invitis talia facere coguntur. Novit enim Diabolus, quod ab introitu regni coeletis, propter poenam damni, aut originale peccatum tales pueri sequestrantur. Unde etiam divitis finale iudicium protahitur, sub quo aeternis cruciatibus deputabantur, cum eo tardius numerus electorum completur, quo

66 Ibid., I, Q. 11, p. 68 [Schmidt, I, p. 158]. The meaning of this final sentence is somewhat puzzling. It possibly reflects an attempt on Institoris' part to explain what he had perceived to be the inordinately high degree of maleficia within the diocese of Brixen. See above, Chapter Three.

67 Ibid., I, Q. 11, p. 68 [Schmidt, I, p. 158].

68 The text derives its authority from the testimony provided by the aforementioned servant-girl of Breisach: "Insuper (ut in prima parte operis) ex illius famulae reductae ad praesentiam in Brisiaco confessione patuit, majora damna fidei circa hanc haeresim malifacurm an obstetricibus inferri, quod etiam quarundam confessio, quae postmodeum incineratae fuerunt, luce clarius demonstravit." Ibid., II, Q. 1, c. 13, p. 152 [Schmidt, II, p. 137]. 
completo mundus consummabitur: et ut in praemissis tactum est, suasu Daemoniorum ex huiusmodi membris unguenta, earum usibus accommoda, conficere habent.

Sed et hoc horrendum facinus silentio praeter eundum in detestationem tanti criminis non est. Nam ubi infantes non interimunt, tamen illos Daemonibus execrando per hunc modum offerunt. Nato enim infante obstetrix, ubi puerpera malefica per se non existit, tunc quasi quid operis pro infantis refocillatione actura, ipsum extra cameram deportat, et sursum elevans principi Daemoniorum, scilicet, Lucifero et omnibus Daemonibus immolat: et hoc in loco coquinae super ignem. 69

Here, the associations among popular midwife practices, the domestic sphere of women, and the stereotypical imagery of heretical diabolism are clearly

established. Institoris continues in a similar vein later in the chapter.

Sed hic dubium oritur: Quid ne operis aut ef ficaciae talis sacrilega oblatio in huiusmodi pueris efficere valeat. Ad quod dici potest, quod sicut triplici ex causa Daemones efficiunt, ita et ad tria nefandissima haec eis deserviunt. Nam primo ex superbia eorum, quae quia semper quaerunt quantum possunt, divinis, rebus et caeremoniis se conformare, ut sic sub specie boni apparentis facilius decipiant. Sic enim et virgines, pueros, mares vel foeminas expetunt a magis, ubi in speculis vel unguibus maleficorum furta sublata, vel alia occulta habent manifestare, licet per corruptos idem ostendere valerent, sed tamen ut singat, se false castitatem amare, quam tamen odit. Cum castissimam virginem summe odit, eo quod caput eius contrivit. Gen.3. Unde sic animas maleficorum et eius credentium per infidelitatis vitium, sub specie virtutis decipiunt. Tertio, ut ipsa perfidia maleficarum amplius in sui augmentum crescat, dum a cunabulis sibi dicatas maleficas servant. 70

69 Ibid., II, Q. 1, c. 13, pp. 152-3 [Schmidt, II, p. 138].

70 Ibid., II, Q. 1, c. 13, pp. 153-4 [Schmidt, II, p. 140]. The text continues: "[...] quod sicut in oblatione, qua homo seipsum Deo offert in sacrificium, recognoscit Deum suum principium et findem: quod quidem sacrificium dignius omnibus sacrificiis aliis exterioribus ab eo impensis, iuxta illud: Sacrificium in Deo spiritus contribulatus, etc. Et hoc quoad principium creationis et finem glorificationis. Ita et ipsa malefica puerum offerens Diabolo, euis animam et corpus, tanquam suo principio et fini damnationis aeternae commendat, unde et non visi miraculose a solutione tanti debiti liberari poterit." Ibid., pp. 154-5 [Schmidt, II, pp. 142-3]. 
Although the linkages between the Heretic-Diabolist and the Midwife-Witch are clear, what still defies explanation is why infanticidal midwifery should be singled out by the text as the most heinious form of maleficium. ${ }^{71}$ It could well be a matter of what might be called "discursive determinism". Institoris was working under the assumption that witchcraft could be identified as a form of heresy, possessing all the essential features of the latter, including cannibalism and infanticide. He would thus be strongly predisposed to single out among the cunning folk subject to his inquisitorial practice that sub-group which could be most easily identified with these heretical practices: midwives. As infanticidal cannibalism and the heretical seduction of the young (i.e. the innocent) were the sign of the worst form of heretical depravity, an equivalent category had to be found among the population of witches. Hence, the midwife was pressed into service as the greatest exemplar of satanic transgression.

One of the interesting features of $I, Q, 11$ is its use of Johannes Nider as a fundamental authority on malefic infanticide - "Adsunt pro confirmatione huius scripta quaedam Io. Nider in suo $\underline{\text { Formicario }}^{72}$, cuius utique et eorum

71 For the best recent discussion of the question of the literary formation of the stereotype of the diabolic midwife, cf. Harley, "Historians as Demonologists: The Myth of the Midwife-witch", passim.

72 Undoubtedly, the Malleus is referring to the following passage in Nider, Formicarius, v, c. 3, p. 356, "Sunt igitur, vel noviter fuerunt, ut idem inquisitor et dominus Petrus mihi retulerunt et fama communis habet, circa districtum Bernensis dominii quidam malefici utriusque sexus, qui contra humanae naturae inclinationem, imo adversus conditiones specierum omnium bestiarum, lupina specie excepta tantummodo, propriae speciei infantes vorant et comedere solent." 
quae scripsit recens memoria superest, unde non incredibilia, sicut apparent, existunt. $^{173}$ The Formicarius serves as the most frequently cited contemporary witch manual within the whole of the Malleus. ${ }^{74}$ Composed circa 1435 , the text is an apologetic work in dialogue form, consisting of a series of discussions between a novice monk ("Piger") and a theologian (Nider) about the problems confronting the Council of Basel in relation to the applicability of Christian virtues to daily life. ${ }^{75}$ Rich in detail on contemporary religious and devotional life, the greater part of the text is based upon personal testimonies supplied to the author by actual persons. This feature is most noticeable in Book Five, which is given over to a series of discussions concerning superstition and maleficium. Nider claims that his authorities on the topic are Peter of Greyerz, a retired secular magistrate from Bern, along with an anonymous Benedictine monk from Vienna and an inquisitor

73 Malleus, I, Q. 11, p. 68 [Schmidt, I, pp. 158-9].

74 The Formicarius is cited a total of thirteen times in the Malleus, cf. I, Q. 11, p. 68 [Schmidt, I, pp. 158-9]; II, Q. 1, "Introductio", p. 94 [Schmidt, II, p. 4] and p. 99 [Schmidt, II, p. 14]; II, Q. 1, c. 2, p. 105 [Schmidt, II, p. 28] and pp. 106-7 [Schmidt, II, pp. 31-3]; , II, Q. 1, c. 4, p. 119 [Schmidt, II, p. 60]; II, Q. 1, c. 11, p. 114 [Schmidt, II, P. 119]; II, Q. 1, C. 15, p. 160 [Schmidt, II, pp. 156-7]; II, Q. 2, "Introductio", p. 173 [Schmidt, II, p. 186]; II, Q. 2, c. 1, p. 179 [Schmidt, II, p. 201]; II, Q. 2, c. 5, p. 189 [Schmidt, II, p. 224] and p. 191 [Schmidt, II, p. 229]; II, Q. 2, c. 7, p. 205 [Schmidt, II, pp. 262-3]. In addition to these explicit citations, the Formicarius is an unacknowledged source in Malleus, II, Q. 1, "Introductio", p. 95 [Schmidt, II, p. 5]; and II, Q. 2, C. 7, pp. 206-7 [Schmidt, II, pp. 265-9].

75 Cf. Schieler, Magister Johannes Nider, pp. 372-82. 
from the diocese of Edua. ${ }^{76}$ As best as can be determined, Peter of Greyerz conducted a series of witch trials at Boltingen in the Simmenthal, a region annexed by Bern only a short time previously, sometime between 1395 and 1405 . These trials apparently resulted in the conviction and execution of a number of suspects accused of diabolism, weather magic, fertility magic, and assorted other sorceries; more precise detail is impossible to ascertain as the discussion in the Formicarius, reputedly based upon the personal testimony of Peter, is the only surviving account of the proceedings. ${ }^{77}$

Nider's text serves as the primary source of the seminal II, Q. 1, c. 2 [Schmidt, II, pp. 26-41] of the Malleus, "Sequitur de modo sacrilegae professionis." Among other things, the chapter reveals the early date at which the satanic stereotype had become thoroughly integrated into judicial proceedings against witches. The Malleus begins with a taxonomic survey of

76 Cf. Nider, Formicarius, V, c. 3, pp. 349-50, "Verum tamen exempla tibi tradam, et doctrinos aliquas petito tuo accomodas, quas habeo portim a doctoribus nostrae facultatis, partim etiam per experientiam cuiusdam probi iudicis secularis et fide digni, qui quaestionibus et fassionibus ac publicas experientiis et privitatis talia multa didicit, cum quo late et profunde saepe contuli, domino Petro videlicet cive Bernensi in Lausanensi dioecesi, qui multos utriusque sexus incineravit maleficos, et alios fugavit e territorio doominii Bernensis. Contuli insuper etiam cum domino Benedicto monacho sancti Benedicti ordinis, qui.licet modo sit religiosus multum viennae in reformato monasterio, tamen ante decennium adhuc in saeculo degens fuit necromanticus, ioculator, minus et trufator apud succulares nobiles insignis et expertus. Áudivi similiter quaedam de sequentibus $\mathrm{ab}$ inquisitore haeretice pravitatis Eduensi, qui nostri ordinis fuit in conventu Lugdunensi devotus reformator et in Eduensi dioecesi multos de maleficiis reos inquisierat."

77 Cf. Cohn, Europe's Inner Demons, p. 204; Hansen, Quellen, p. 91; Hansen, Zauberwahn, pp. 437-8; Kieckhefer, European Witch Trials, p. 117 ; Lea, A History of the Inquisition in the Middle Ages, III, pp. 534-5; Russell, Witchcraft in the Middle Ages, pp. 215-16. 
the diverse types of malefic transgressors.

in genere triplices apparent Maleficae [...] scilicet laedentes, sed curare non valentes. Curantes et ex aliqio singulari pacto cum Daemone inito non laedentes et curantes. Ita et inter laedentes unum genus aliae supremum, in quo genere existentes, omnia alia maleficia, quae aliae sparsim exercent perpetrare valent. Unde profitendi ubi describitur, satisdeclarat de aliis speciebus. Sunt auem hae, quae contra humanae naturae inclinationem, imo omnium ferarum, propriae speciei infantes vorant, et comedere solent. 78

It goes on to stipulate that its primary interest is to cast light upon the

nefarious activities of the last, the most dangerous, category.

Et haec est suprema species in maleficis exercendis: sunt enim quae ad innumera nocumenta alia tendunt. Hae enim grandines $t$ auras laesiveas cum fulminibus exagitant, sterilitatem in hominibus et iumentis procurant. Infantes quos non devorant, Daemonibus (ut supra patuit) of ferunt, aut alias occidunt. Sed Hoc circa infantes, non renatos fonte baptismatis, quos autem devorant renati sunt ut patebit, sed non nisi Deo permittente. Sciunt et infantes, propre aquas ambulantes, in ipsas, nullo vidente, in aspectu parentium proiicere: equos sub insessoribus phreneticos facere, de loco ad locum per aëra, vel corporaliter, vel imaginarie transmeare, Iudicum et praesidentium animos ne eis nocere valeant immutare taciturnitatem sibi et aliis in tormentis procurare in se capientium manus 79 et animos tremorem magnum incutere occulta aliis manifestare, et quaedam futura, ex Daemonuum informatione, quae videlicet aliquam causam possunt habere naturalem praedicere. Vide quaestionem, an Daemones valeant futura praecognoscere in 2 . sent. distin. $12^{80}$ absentia velut praesentia conspicere, ad amorem vel odium inordinatum mentes hominum immutare, ictu fulminis non ninquam quem volunt, seu etiam aliquos homines et iumenta interimere: vim generativam, aut etiam potentiam coëundi auferre, aorsum procurare

78 Malleus, II, Q. 1, c. 2, pp. 104-5 [Schmidt, II, pp. 26-7].

79 A possible reference to staedlin's ability to evade his captors by bewitching them, cf. ibid., II, "Introductio", p. 95 [Schmidt, II, p. 5]. This account is virtually verbatim derived from Nider, Formicarius, V, c. 4, pp. 354-5.

80 Cf. Aquinas, Sententiarum, II, D. 12, fols. $38 \mathrm{v}-41 \mathrm{v}$. 
infantes in utero matris solum exteriori tactu interimere, solo etiam visu absque tactu interdum homines et iumenta maleficiare et mortem inferre, proprios infantes Daemonib[us] dedicare, et breviter omnia ut praemissum est, pestifera, quae aliae Maleficae sparsim procurare sciunt, quod Dei iustitia talia fieri permittit. Haec in illo genere supremo existentes perpetrare sciunt, non autem e converso.

Hoc tamen est commune omnium spurcitias carnales cum Daemonibus exercere, ideo et ex illorum modo profitendi, qui in supremo genere existunt, aliarum maleficarum modum faciliter quis capere, potest. $^{81}$

This exhaustive compilation of malefic offences is rendered ideologically

coherent via the introduction of the heretical-diabolic Sabbat; all such actions

are dependent upon the witch's being invested with demonic power by Satan

through the ritualistic act of homage.

Modus autem profitendi duplex est: Unus solemnis persimilis ad votum solenne. Alius privatus qui seorsim Daemoni quacumque hora fieri potest solennis inter eos fit, ubi maleficae in certam concionem statuto die veniunt: et Daemonuem in assumpta effigie vident hominis, qui dum super servandam sibi fidelitatem, cum temporalium prosperitate, et longitudine vitae hortatur, illae quae adsunt novitiam suscipiendam sibi commendant. Et Daemon si de abneganda fide, et cultu Christianissimo, et de extensa muliere, sic enim et bectissimam virginem Mariam noncupant, et si de sacramentis nunquam venerandis: invenerit novitiam seu discipulum voluntarium, tunc Daemon manum extendit, et vice versa discipulus seu novitia, stipulata manu illa servare promittit et Daemon habitis praemissis, statim subiungit haec non sufficere; et ubi discipulus quaenam alterius sint facienda inquirit, Daemon homagium petit, quod continet, ut in anima et corpora, sibi alternaliter pertineat, et pro alios quoscunque utriusque sexus sibi associare velit. Adiungit denique, ut

81 Malleus, II, Q. 1, c. 2, p. 105 [Schmidt, II, pp. 27-8]. The text is insistent that such categories correspond to actual malefactors, and it refers to a variety of judicial and ecclesiastical authorities to substantiate its claims. "Fuerunt autem tales, dudum, ante triginta annos in confinibus Sabaudiae, versus dominium Bernensium ut recitat. Nider in suo Formicario: Nunc autem in confinibus Lombardiae, versus dominium ducis Austriae: ubi et inquisitor Cumanus, ut in praecedente parte tactum est, uno anno quadraginta et unam Maleficam incinerari fecit, et fuit anno domini, 1485, qui etiam adhuc continue inquirendo laborat", Ibid., II, Q. 1, c. 2, p. 105 [Schmidt, II, pp. 28-9]. See above, Chapter Three. 
certa unguenta ex of fibus et membris puerorum, et praecipue renatorum fonte baptismatis, sibi conficiant per quae cunctas suas voluntates explere cum sua assistentia poterunt. 82

The text provides three lengthy accounts of such satanic ceremonies, all derived in essence from the Formicarius. The first is based upon the account allegedly provided to Nider by the unknown inquisitor of Edua.

Doctor praeciuus, qui etiam nostri temporibus miris clarvit scripturis, recitat, hoc ex relatu Inquisitoris Eduensis Diocesis, qui etiam in ipsa Dioeces; multos de Maleficiis inquisierat et incinerari fecerat.

Dicit enim, praefato Inquisitore, mihi referente, percepi quod in Lausaniensi ducatu quidam malefici proprios natos infantes coxerant, et comederant. Modus autem discendi talem artem fuit, ut dixit, quod Malefici in certam concionem venerunt, et opere eorum verisimiliter Daemonum in assumpta imagine viderunt hominis, cui discipulus habebat necessario dare fidem de abnegando Christianissimo et de Eucharistia nunquamm adoranda, et de calcando super crucem ibi latenter valeret. ${ }^{83}$

The second is derived from the testimony of Peter of Greyerz:

Fuit insuper fama communis Petro Iudice in Botilgem referente, quod in terra Bernensi tredecim infantes devorati essent a Maleficiis: quamobrem etiam publica iustitia satis dure exerceatur in tales parricides. Cum autem Petrus quaesivisset a quadam capta Malefica, per quem modum infantes comederent: illa respondit, Modus ist est: nam infantibus nondum baptizatis praesertim quando signo crucis non muniuntur, et orationibus (Lector adverte quod ideo non baptizatis) praecipue insidiantur instinctu Diaboli, ut non baptizentur, nos in cunabulis, vel ad latera iancentes parentum, caeremoniis nostris occidimus: quos postquam putantur oppressi esse, vel aliunde mortui, et de tumulo clam furto recipimus, et in caldari decoquimus, quousque evulsis ossibus tota caro efficitur bene potabilis, de solidiore materia unguentum facimus, nostris voluntatibus et artibus ac transuactionibus accomodis: de liquidiore vero

\footnotetext{
82 Ibid., II, Q. 1, c. 2, pp. 105-6 [Schmidt, II, pp. 29-30].

83 Ibid. II, Q. 1, c. 2, p. 106 [Schmidt, II, p. 31]. The
} passage is verbatim taken from Nider, Formicarius, v, c. 3, pp. 350-1. 
humore flasconem et utrem replemus de quo is qui potatus fuerit, additis paucis caeremoniis, statim conscius efficitur et magister nostrae sectae. $^{84}$

The third example is also drawn from Peter of Greyerz:

Sequitur ad idem modus alius magis distinctus et clarus. Nam iuvenis quidam cum uxore malefica captus, in Bernensi iudico, seorsim ab eadem et in distincta turri repositus, dixit: $\mathrm{Si}$ meorum facinorum veniam consequi possem, omnia quae de Maleficiis scio libens patefacerem, mori enim video me oportebit. Cumque per literatos circunstantes audisset omnimodam posse consequi veniam, si vere poeniteret, tunc laete se morte obtulit, et modos primaeve infectionis deservit, Ordo in quit, talis est, quo etiam seductus sum. Oportet primo ut Dominico die antequem aqua benedictu consecratur, discipulum futurum cum magistris Ecclesiam introire et ibidem abnegare coram eis Christum, eius fidem, baptisma, et universalem Ecclesiam. Deinde homagium praestare magisterulo 85 id est, parvo magistro, ita enim Daemonem, et non aliter vocant. Ubi notandum, quod iste modus cum aliis recitatis concordat. Nec obstat, quod Daemon interdum praesens est, ubi homagium sibi praestatur interdum vero non: dolose enim tunc operatur, cernens dispositionem futuri discipuli, quem fortassis ob suam praesentiam tenquam novitium

84 Malleus, II, Q. 1, c. 2, pp. 106-7 [Schmidt, II, pp. 31-2]. Again, the Malleus draws verbatim on Nider, Formicarius, v. c. 3, p. 351 .

85 Nider claims that magisterulum is another name for the Devil; cf. Nider, Formicarius, V, c. 4, p. 356. Nicholas Jacquier relates a first-hand account of the sabbat which involved homage to a presiding demon known as Tonyon. Cf. Jacquier, Flagellum Haereticorum, c. 7, p. 41, "Hoc autem anno scilicet 1458 quidum iudicialiter sponte confessus fuit, quod cum olim ipse esset iuvenis, scilicet quinque vel sex annorum, mater eius ipsum cum quodam eius sorore duxit ad synagogam fascinariorum, et ipsos tres liberos daemoni obtulit, apparenti in effigie cuiusdam hirci, instruendo eos, quod ille esset eorum dominus et magister, qui eis mulat bona facturus esset; et facit ipsa mater dictos liberos tangere praedictum daemonem manu super caput effigiei praedictae, et ipse daemon, quem vocabant Tonyon, omnes tres praedictos anteriori pede tetigit in eorum coxis et eis signum impressit indelebile, quod signum praedictus ipse, qui hoc confitebatur, deferebat, apparens ad quantitatem unius fabae, qui et pluribus annis post praedictam introductionem perseveravit in praedicto cultu sectae cum fratre et sorore supradictis; erat enim circiter sexaginta annorum, quando supradicta confitebatur sponte ut dictum est. Gesta igitur et conventiones huius haeresis et sectae fascinariorum, non sunt fantasticae illusiones, sed perversae et perfidae vigilantium reales et corporales actiones, damnabilesque volentium et consenttientium operationes, in obsequium malignorum spirituum exhibitae." 
retrheret timoris causa, cum tamen alias per sibi notos et familiares facilius aestimat eum assentire. Ideoque eum et tunc magisterulum vocant, cum absens est, ut minore terrore, ex parva aestimatione magistri concutiatur. Sequitur postremo: de utre bibit spuradicto quo facto, statim se in interioribus sentit imagines nostrae artis concipere et retinere super principales ritus huius sectae. In hunc modum ait, seductus sum. Et uxor mea: quam tantae pertinaciae esse credo, ut potius incendium sustinet, quam minimam fateri velit veritatem: sed heu ambo rei sumus. Sicut dixit iuvenis, ita veritas per omnia reperta est, nam praeconfessus iuvenis in magna contritione mori visus est. Uxor vero testibus convicta, nihil veritatis, nec in ipsa tortura fateri voluit, nec in morte: sed incendio praepanto pessimis maledixit, et sic incinerata fuit. Ex quibus liquet modus profitendi earum solemnis. 86

Although the text recognizes that Lucifer may manifest his will

in diverse ways, his essential goal is said to be to maximize his offence against

God by leading as many souls as possible into sin.

Verum super hoc, quod Diabolus homagium recipit, aliqua sunt advertenda, qua videlicet de causa, et quam differenter hoc faciat. et primo. Nam licet hoc faciat principaliter ad maiorem of fensionem Divinae maiestatis, creaturam ei dictatum sibi usurpando, et ob maiorem certitudinem futurae illius damnationis, quam summe af fectat. [...] saepe repertum est a nobis, tale homagium ad certos accepisse annos simul cum professione. Interdum professionem tantum et homagium ad certos annos distulisse. 87

This, then, is the crucial point - the ritual of satanic homage leads the soul into perfidy, away from God, and as such constitutes an act of heresy.

Et dicamus professionem consistere in fidei totali, aut partiali abnegatione. Totali, ut supra tactum est, cum fides ex integro abnegatur. Partiali, cum ex pacto inito, habet caeremonialia quaedam contra statuta Ecclesiae observare, ut Dominicis diebus ieiunare, aut sextis feriis

86 Malleus, II, Q. 1, c. 2, p. 107 [Schmidt, II, pp. 32-3]. This passage is verbatim taken from Nider, Formicarius, V, C. 3, pp. $351-2$.

87 Malleus, II, Q. 1, c. 2, p. 108 [Schmidt, II, p. 34]. 
carnibus vesci, aut certa crimina in confessione celare, vel aliquid simile perpetrare $_{88}$ Homagium vero dicamus consistere in corporis at animae traditione. 88

Part Three of the Malleus provides a list of five criteria which

have to be fulfilled in order for the status of the accused as a heretic to be established.

Nam ad hoc quod aliquis sit proprie haereticus, quinque requiruntur. Primum est, ut sit error in ratione. Secundum est, quod error ille sit circa ea, quae sunt fidei, vel contra veritatem determinationis Ecclesiae, in iis quae pertinent ad fidem, vel bonos mores, et necessario ad consequutionem vitae aeternae. Tertium est, quod error talis sit in illo qui Catholicum fidem professus est, alius enim esset Iudaeus vel paganos, non haereticus. Quartum est, quod talis error in eo, qui fidem suscepit sit taliter quod aliquam venitatem de Christo confiteatur pertinentem ad divinitatem, vel humanitatem, alias si in totum discederet, esset Apostata. Quintum est, ut talem errorem pertinaci voluntate et obstinata eliget, et sequatur. ${ }^{89}$

The juro-ecclesiastical status of the witch as heretic is discussed most

extensively in I, Q. 14 [Schmidt, I, pp. 178-88]. According to the Malleus,

quia per infidelitatem homo maxime a Deo elongatur, ideo maius omnibus peccatis maleficium infidelitatis existit. Et hoc declarantur per nomen Haersis, quod est etiam Apostasis a fide de simul, et quod tota earum vita peccatum est.

De primo: nam cum peccatum infidelitatis constitit in renitendo fidei. Et hoc potest dupliciter fieri, vel quia renititur fidei nondum susceptae, aut susceptae. Si primo modo tunc est infidelitatis Paganorum seu Gentilium: Si secundo modo, tunc iterum dupliciter, quia aut renititur Christianae fidei susceptae veritatis. Primo modo est infidelitatis Iudacorum. Secundi modo infidelitatis Haereticorum.

Unde patet, quod haersis Maleficarum inter tres species infidelitatis

88 Ibid., II, Q. 1, c. 2, p. 108 [Schmidt, II, pp. 34-5].

89 Ibid., III, "Introductio", pp. 214-15 [Schmidt, III, pp. 1213]. 
gravissima existit. 90

The text adopts the definition of apostasy formulated by Thomas Aquinas in the second part of the Second Book of the Summa Theologiae, "Nam secundum D. Thom. Secunda Secundae, q. 12. ${ }^{91}$ Apostasia importat quandam retrocessionem a Deo et religione, quae fit per diversos modus, quibus homo coniungitur Deo vel per fidem, vel per subiectum ad obendium voluntatem, vel per relionem et clericatum." 92 Within this context, maleficium can truly be best understood as a form of apostasy.

Unde et Apostasia, de qua loquimur super Apostasum Maleficarum, dicitur Apostasia perfidiae, quae et tanto gravior, quanto et cum inimico fidei rationis salutis per pactum expressum peragitur. Hoc enim habent facere Maleficae et hoc inimicus ille exegit in toto vel in parte. Repertae sunt enim per nos Inquisitores, quae omnes fidei articulos abnegaverant, quasdam vero certos in numero, semper tamen confessionem, veram et Sacramentatem habebant abnegare. ${ }^{93}$

The text dismisses any objection that it may in fact be possible for witches internally to maintain their devotion to the Faith although they deny it externally through their diabolic rituals. The Malleus distinguishes between two separate degrees of the apostasy of perfidy; the outward acts of perfidy practised by Christians inhabiting Moslem territories, and the ones perpetrated by those who dwell within Christian lands, yet enter a Pact with Satan. The

90 Ibid., I, Q. 14, p. 78 [Schmidt, I, p. 182].

${ }^{91}$ Cf. Aquinas, Sententiarum, II, D. 4, art. ult., fols. 17r-18v.

92 Malleus, I, Q. 14, p. 79 [Schmidt, I, p. 183].

93 Ibid., I, Q. 14, p. 79 [Schmidt, I, p. 184]. 
treatise argues that under absolutely no circumstances may clemency be shown towards those of the latter category.

Malefici autem quantumcumque fidem retinent corde, et abnegant ore. Apostatae tamen iudicantur eo quod foedus cum morte, et pactum cum inferno pepigerunt. Unde et S. Thom. in 2. dist. 4. art. ult. ${ }^{94}$ loquens de similibus operibus magicis. Et qui quocunque modo auxilium petunt a Daemonibus, dicit: In omnibus est apostasia a fide, propter actum initum cum Daemone, vel verbotens si invocatio intersit, vel facto aliquo, etiamsi sacrificia desint. Non enim potest homo duobos dominus servire. 95

The Malleus proceeds to hold that the customary array of penalties normally applied to heretics - excommunication, imprisonment, banishment, disinheritance/confiscation of property, execution in lieu of repentance - are irrelevant in the case of witches because of the severity of their transgressions and the damage they inflict.

His autem modis mulatate maleficas non videtur sufficere, cum non sint simplices haereticae, sed apostatae, et ultra hoc quod in ipsa apostasia, et non hominibus propter metum, carnis oblectamenta, fidem abnegat, ut supra tactum est: Sed ipsis Daemonibus ultra abnegationem, homagium, corpora, et animas offerendo praestant. Ex quibus satis probabile videtur, quod quantumque poeniteant, et ad fidem revertantur non debeant sicut alij haeretici carceribus perpetuis mancipari, sed ultimo supplico puniri: et hoc etiam propter damna temporalia, hominibus et iumentis variis modis illata leges imperant. ${ }^{96}$

Accordingly, the witch, as diabolic apostate, is to be rigorously subjected to the fullest degree of inquisitorial jurisprudence.

\footnotetext{
94 Cf. Aquinas, Sententiarum, II, D. 4, art. ult., fols. 17r-18r.

95 Malleus, I, Q. 14, p. 79 [Schmidt, I, pp. 184-5].

96 Ibid., I, Q. 14, p. 81 [Schmidt, I, p. 188].
} 
Ad hanc accusationem [of witchcraft] quidlibet admittitur quasi in crimine laesae Majestatis: ipsam enim propemodum pulsant majestatem Divinam. Item quod quaestionibus ad interrogandaum subiiciantur. Subdit: Et quilibet nulla dignitate ${ }^{97}$ obstante quaestioni subiicitur: etiam qui convincitur, vel si denegat facinus suum, sit eculeo deditus, ungulisque sulcantibus latera, perferat poenas dignas suo facinore. ${ }^{98}$

This passage encapsulates what is perhaps the very essence of the diverse literary techniques infusing the Malleus. Although fully one third of the text is devoted to discussions concerning the propriety of the various judicial and inquisitorial techniques involved in witch hunting ${ }^{99}$, such stipulations only possess an intrinsic interest and meaning within the relation to the more basic discursive formulas sustained throughout the book's First and Second Parts, formulas which establish a total theological and cultural identification between Witch and diabolic Heretic/Magician. The application of inquisitorial jurisprudence, and all that it entails, is rendered justifiable only in so far as the purported object of such techniques is in fact perceived - and, though that act

97 This is undoubtedly an expression of that same desire to overcome local resistance to inquisitorial activity which manifests itself through the stipulations of the Summis desiderantes concerning the universal applicability of papal censure for failure to comply with the inquisitors. See above, Chapter Two.

98 Malleus, I, Q. 1, p. 4 [Schmidt, I, p. 9].

99 CE. ibid., III, "Ad opus judiciale, tam in foro Ecclesiastica, quam civili, contra Maleficos, ac omnes haereticos", Q. 1-35, passim [Schmidt, III, pp. 1-228]. The greater part of this material is derived from an earlier treatise on inquisitorial procedure, composed by Institoris immediately following his failure at the proceedings in Innsbruck in October 1485. It is an account of procedural guidelines regulating the accusation and interrogation of suspected witches, composed for a certain "Reverendissima Paternitas Vestra", which almost certainly refers to Bishop Georg Golser. Cf. Hartmann Amman, "Eine Vorarbeit des Heinrich Institoris für den Malleus Maleficarum", passim. See above, Chapter Three. 
of perception, constituted - in a highly particular ideological fashion. Institoris

in fact announces this to have been his main purpose in composing the text so

as to encourage secular magistrates to assist the Inquisition in its pursuit of

identified satanic deviants.

principalis intentio nostra in hoc opere sit, ab inquisitione maleficarum, quantum cum Deo fieri possit, nos inquisitores partium superioris Allemaniae exonerare, fuis iudicibus ad puniendum relinquendo, et hoc propter negotij ardvitatem, dum tamen indemninati fiedei, et salvti animarum non eo minus provideretur, quare et praesens opus aggressi sumus: ipsis iudicibus modos cognoscendi, diffiniendi et sententiandi relinquendo.

Ideo ad ostendendum quod Episcopi contra maleficas in multis procedere possint, etiam seclusis Inquisitoribus, licet ipsi Episcopi sine temporali et civili iudicio, ubi punito transit in vindictam sanguinis, non ita procedere valeant. 100

The effects of such inquisitorial practice, especially when conducted in accordance with the fundamental precepts of the witch stereotype, have already been thoroughly studied ${ }^{101}$ and require no further comment in the context

Cf. Malleus, III, "Introductio", pp. 212-13 [Schmidt, III, pp. 7-8]]. Cf. also ibid., III, "Introductio", p. 221 [Schmidt, III, pp. 29-30], "Videtur etiam quod in haeresi maleficarum, licet non in aliis haeresibus, etiam ipsi Dioecesani suas vices ad cognoscendum, et iudicandum in soro civili committere valeant tum, ut in argumentis tangitur, quod hoc crimen maleficarum non est mere Ecclesiasticum, imo potius civile, propter damna, quae inferuntur temporalia, tum etiam, quia leges speciales in punitionem maleficarum, quoad omnem viam punitionis editae cernuntur.

videtur denique, quod haec via plurimum in exterminium maleficarum deserviret, et in maximum inuuamen ordinarium coram tremendo iudice, super districtum examen quod exigetur, cum teste scriptura iudicium durissimum iis qui praesunt immineant. Et secundum hanc differentiam procedemus, videlicet quod iudex secularis cognoscere et iudicare potest, usque ad sententiam diffinitiuam ad poenitentiam, quam ab ordinariis recipiet, secus super sanguineum, quam per se ferre potest."

101 Cf. Midelfort, "Witch Hunting and the Domino Theory", passim; and Midelfort, Witchhunting in Southwestern Germany 1562-1684, esp. chs. 4 and 5 . 
of this study. Rather what this chapter has essayed is a delineation of certain crucial structural features, reproduced within the Malleus Maleficarum, which reveal the actual process of the literary composition of that stereotype, and which signify an irreducibly autonomous historical phenomenon within its own right, without which no other facet of that collective event known as the "European Witch Hunt" can be rendered intelligible. 


\section{CONCLUSION.}

Any historical study of merit should raise more questions than it answers; hopefully, this study has accomplished that goal. I identify at least four possible future lines of enquiry, all derived from various facets of this dissertation. The first of these is what I would call "the politics of scholasticism" - that is, the ways in which certain crucial features of the development of scholastic theology in the late medieval period can be situated within a series of juro-political changes vital to the established interests of the Roman Church. As already discussed in Chapters One and Five, this would entail the examination of any possible interrelationship between the formation of the philosophical language of scholasticism and the political imperative to combat rival and/or deviant religious movements. In this view scholasticism would be interpreted as a continuation of the war against heresy by other means, allowing us to detect a current of political imperatives underlying hitherto "politically neutral" theological writings and utterances.

The second field of investigation would focus upon the role played by curial politics within the rise of the first major wave of witchcraft prosecutions of the mid-fifteenth century following the Council of Basel. This is an area not only of witchcraft studies but also of ecclesiastical history which seems to me to be badly under-researched. Historians have generally tended to think in overly deterministic monocausal modes of explanation without adequately taking 
into account the inherent qualitative differences that existed at different stages of that allegedly continuous event known as the "European Witch Hunt". Analyses have generally clustered around the latter stage of the process especially the period of the "great hunts" beginning in the second half of the sixteenth century - and have presented as total explanations models which are pertinent to only one portion of the whole. An especially good example of this is Christina Larner's Enemies of God; while it presents what is an arguably plausible account of growing judicial concern with witches, it fails to explain how any prosecutions could have taken place prior to 1519 . I believe that my study of the immediate political background to the composition and publication of the Malleus represents a step forward in compensating for this deficiency, by drawing attention to certain unique features of fifteenth-century forms of prosecution. These, in turn, are directly related to the papal opposition to conciliarism and the curia's reliance upon the inquisitorial process as a means of identifying and persecuting its opponents as representatives of a form of religious deviancy.

Closely related to the second is a third possible form of future enquiry, namely a thorough examination of both the political nature and function of inquisitorial jurisprudence. There is quite simply no adequate full-length study of the development and employment of the judicial theories and techniques of the Inquisition, much less any attempt systematically to link them with wider 
political and ecclesiastical concerns. It appears to me that the Malleus itself, with its encyclopedic summation of canonical doctrine and its detailed application of inquisitorial procedures in the field of practice, would serve as an ideal starting-point for such an undertaking.

Finally, one could extend the study of the Malleus to cover questions concerning the ideological representation of certain deviant groups within the European culture of the early modern period. Insights derived from this dissertation could be most profitably employed in the study of two groups in particular, the midwife and the madman. It was within demonological treatises such as the Malleus that the notion of the demonic and infanticidal midwife was first established. The midwife, along with the witch, soon developed a cultural life of her own as the archetypal representation of destructive femininity and a keystone in that transformation of gender relations which so pervades the question of witchcraft prosecutions. Furthermore, the figure of the midwife played a pivotal role in the early development of modern medicine, the embodiment of the non-professional female folk practitioner to be socially excluded through the rise of the professional male university physician. In this respect, it would be interesting to situate the ideological role(s) of the midwife in the standardization and policing of medical practice that played so vital a part in the expansion of state- and administrative powers and functions during the sixteenth and seventeenth centuries. Equally useful insights could be 
derived from a study of the cultural representations of insanity and the insane in relation to demonological doctrine. It is quite clear, for example, that the very first attempts to obtain a "naturalistic" understanding of mental illness were inextricable from the delineation of cases of melancholia from authentic bewitchment and/or possession. By such a study one may continue with what has been the fundamental purpose of this work, that is to locate the production of a literary text within a matrix of socio-political relations and to analyze the means by which that text subsequently affected the forces that gave birth to it. 


\title{
APPENDIX A.
}

\section{The "Apologia Auctoris".}

\author{
Reprinted in Schmidt (ed)., \\ Jakob Sprenger, Heinrich Institoris: Der Hexenhammer \\ (Malleus Maleficarum), pp. XLII-XLIV.
}

The "Apologia" of the Malleus deserves comment in so far as it helps to cast some further light on the problem of authorship. At first glance the text is remarkable neutral with regards to the question of authorial identity.

Cum inter ruentis saeculi calamitates, quas proh dolor non tam legimus quam passim experimus, vetus oriens damno suae ruinae irrefragabili dissolutus ecclesiam, quam novus oriens homo Christus Jesus aspersione sui sanguinis fecundavit, licet ab initio variis heresum contagionibus inficere non cessat, illo tamen praecipue in tempore his conatur, quando, mundi vespere ad occasum declinante et malitia hominum excrescente, novit in ira magna, ut Johannes in Apocalypsi testatut, se modicum tempus habere. Quare et insolitam quandam haereticam pravitatem in agro dominico succrescere fecit, haeresim inquam maleficarum, a principaliori, in quo vigere noscitur, sexu denotando. Quae, dum innumeris machinatur insultibus, hoc tamen in singulis, quod cogitatu terribile, deo nimium abominabile et omnibus Christi fidelibus odibile cernitur, operibus expletur. Ex pacto enim cum inferno et foedere cum morte foetidissimae servituti pro earum pravis explendis spurcitiis se subiicint. Praeterea ea, quae in quotidianis aerumnis, hominibus, iumentis et terrae frugibus ab eis deo permittente et virtute daemonum concurrente inferuntur. Inter quae mala nos inquisitores Jacobus Sprenger una cum carissimo ab apostolica sede in exterminium tam pestiferae haeresis socio deputato, licet inter divinorum eloquiorum professores sub Praedicatorum ordine militantium minimi, pio tamen ac lugubri affectu pensantes, quid remedii quidve solaminis mortalibus ipsis pro salutari antidoto foret administrandum, huic operi prae cunctis aliis remediis pios submittere humeros dignum iudicavimus, confisi de melliflua fargitate illius, qui dat omnibus affluenter et qui calculo sumpto de altari forpice tangit et mundat labia imperfectorum, in finem optatum cuncta perducere. Verum cum in operibus hominum nil fiat adeo utile et licitum, cui non possit aliqua pernicies irrogari, ingeniola etiam 
nostra ad acumen non perveniunt veritatis, nisi lima alterius pravitatis plurimum fuerint abrasa, ideo, qui de novitate operis nos redarguendos estimat, ad certamen illius confidenter accedimus. Sciat tamen, hoc ipsum opus novum esse simul et antiquum, breve pariter et prolixum, antiquum certe materia et auctoritate, novum vero partium compilatione earumque aggregatione, breve propter plurimorum auctorum in brevem perstrictionem, longum nihilominus propter immensam materiae multitudinem et maleficarum imperscrutabilem malitiam. Nec hoc dicimus ceterorum auctorum scriptis praesumptuose derogando nostrumque opus iactanter et inaniter extollendo, cum ex nostro ingenio pauca et quasi nulla sint addita. Unde non nostrum opus sed illorum potius censetur, quorum ex dictis fere sunt singula contexta. Qua simul ex causa nec poemata condere nec sublimes theorias cepimus extendere, sed excerptorum more procedendo ad honorem summae trinitatis et individuae unitatis super tres partes principales: originem, progressum et finem, malleficarum malleum tractatum nuncupando, aggredimur, recollectionem operis socio, executionem vero his committendo, quibus iudicium durissimum imminet eo, quod in vindictam malorum laudem vero bonorum constituti cernuntur a deo, cui omnis honor et gloria in saecula.

The "Apologia" has many interesting facets which deserve commentary - in some ways the text serves as a microscopic recapitulation of some of the most central themes of the Malleus. Not only does it stridently assert the underlying correlation between femininity and witchcraft, it also seeks to represent the heresy of diabolism in terms of an infectious contagion, a rhetorical play that underscores the deep structural affinity between the stereotypes of leper, heretic, and witch. The reality of the demonic pact is taken as the main signifier of the identity of the witch, supplemented by an allusion to the appropriate biblical reference taken from Isaiah 28:15. The "Apologia" also strives to bestow upon the Malleus the greatest possible degree of legitimizing status, re-presenting the text as veritably nothing more than a systematic 
compilation of previous authoritative enunciations. The text makes much of the papal dispensation to the two inquisitors as a means of signifying their juropolitical authority, going so far as to replicate almost verbatim the Witch Bull's identification of malefice with the demonic infliction of sterility and blight.

The evidence actually provided concerning the question of authorship, however, is highly ambivalent. It is obvious that the "Apologia", as its very title suggests, presents itself as the defence of the single author of the Malleus, Jacob Sprenger being explicitly cited by name. Indeed, the general eschatological and apocalyptic tone evidenced by the text, far more pronounced than anything in the main body of the Malleus itself ${ }^{1}$, would tend to mark Sprenger, the disciple of the renowned Alain de la Roche, as the author of the work. $^{2}$. Sprenger's position as the sole author of the whole of the Malleus

1 An example: "Quoad secundum, quod universitatem malorum, sive in culpis, sive in poenis iuste Deus permittat, et praesertim iam refrigescente, et mundo ad occasum declinante [...]" Malleus, I, Q. 2, p. 72 [Schmidt, I, p. 167].

2 With regards to de la Roche's role in exacerbating apocalyptic concerns, see the acerbic profile provided by Johann Huizinga in The Waning of the Middle Ages, pp. 180-1. "The description of his numerous visions is characterized at the same time by an excess of sexual imagination and by the absence of all genuine emotion. The passionate tone which, in the grand mystics, makes these too sensuous images of hunger and thirst, of blood and voluptuousness bearable, is altogether lacking. The symbolism of spiritual love has become with him a mere mechanical process. It is the decadence of the medieval spirit [...]. [In the late Middle Ages] Human imagination contained, as the inevitable complement of the sweetness of celestial visions, a black mass of demonological conceptions which also sought expression in language of ardent sexuality. Alain de la Roche forms the link between the placid and gentle pietism of the devotio moderna and the darkest horror produced by the medieval spirit on the wane: the delusion of witchcraft, at that time fully developed into a fatally consistent system of theological zeal and judicial severity." 
cannot, however, be adequately demonstrated by this piece, for the author of the "Apologia" himself declares in the concluding sentence that the actual composition of the work, a compilation of previous declarations, had to be left to his collaborator, that is Heinrich Kramer. ${ }^{3}$ As with so much of the available evidence concerning the question of authorial identity the "Apologia" indirectly adds further weight to Kramer's claim to being the main driving force behind the production of the text of the Malleus Maleficarum.

3 Hansen, Quellen, pp. 405-6. 


\title{
APPENDIX B.
}

\section{Letter of 17 December 1484 from the Mayor of}

\author{
Ravensburg to Archduke Sigismund.
}

\author{
Reprinted in Müller, "Heinrich Institoris \\ der Verfasser des Hexenhammers", pp. 399-401.
}

Dem durchluchtigisten fürsten und herrn herrn [sic] Sigmunden, Ertzhertzog zu Oesterrich zu Steir zu Kerndten und zu Krain u. unserem gnedigisten herren.

Durchluchtigister fürst und gnedigister herre uwern fürstliche gnauden sien unser undertenig und gantz gutwillig dienste mit allem vlis allzit zuvor berait. Als uwer fürstlich gnaud uns ietz hat schriben lausen, - die angelangt sig -, wie ain doctor predigerordens ${ }^{4}$ zu uns komen sin söll, zu besuchen und zu straufen die hechsen und unholden, der ettlich derselben unholden für uns und uf unser rathus durch sin kunst brächt und darnach dieselben und ander mer verprennen söll haben lausen, mit beger uwer fürstlich gnaud gestalt der sachn und wie die zugangen sien, grundtlich zu berichten $u$. Lut desselben uwer gnauden schribens haben wir mit undertenigem vliß, als billich ist, nach wirden empfangen und fügen daruf uwer gnaud zu vernemen, daz war ist, in diser nechstvergangen herpstzit ain solher doctor in unser statt ist komen mit bäpstlichen bullen ${ }^{5}$ sins empfelhs [sic] und furnemens halben, davon er abschriften ald copien an den kirchtieren uf schlachen ließ und daruf ettlich tag an der kantzel geprediget und aller mengi, fröwen und mannen, bi bäpstlichen, höchstem bann gebieten tät also: Wer der oder die weren, die ainiche hechsen ald unholden wisten oder von iemands gehört hetten, daz sie die wisten, ald in arckwon hetten, oder daz ain böser lumd uf si gieng, ald wa iemand schad an lüt ald vech beschechen wer, daz

4 Institoris - Although he is never referred to by name, the close correlation between the events described in the missive and the account provided in the Malleus strongly indicates that the said Doctor could have been none other than Heinrich Kramer himself.

5 The "bullen" referred to here could not possibly be the Summis desiderantes which was not issued until 9 December 1484. It appears more likely that what is meant are copies of some of the papal rescripts issued by Innocence VIII recognizing Kramer's authority as a papal inquisitor. See above, Chapter Two. What is most important to note is Kramer's obvious concern with the immediate establishment of his political authority within the region. 
man uf ettwern argkwan hette, die sölten bi gehorsame oberürtz gebots $\mathrm{zu}$ im komen und im sölh häxen ald verlümbdt argkwönig personen angeben mit irn umbstenden, waz ieder von im wiste, gesechen ald von anderen lüten gehört hette. Da ist nu ain grosser zulauf von vil luten worden, vil frowen und manspersonen zu im gangen. So er nu die lut bi iren gelüpten und aiden verhört hat, und daz ingeschrift furgehalten, uf daz haben wir ettlich wips personen in unser gevengknuß prächt, dar under zwo veriechen hand, wie daz si sich dem tüfel ergeben habint und mit im ir gespenst der unluterkait gepflegen ${ }^{6}$, ouch hägel und ungewitter helfen machen, derglich lüt und vech gelembdt und gesert und vil ander derglich zobri gespenstes vil iar und zit getriben; und demnach haben wir zu inen mit dem für richten lausen.

Er hat uns ouch dabi zu verstend geben, wenn man zu inen griffen werd, daz man dann sölh personen von der erd ufheb und si nit mer daruf ouch si bescheren laufe und sonder so sige daz ain mergkliche ursach: wenn man si frauget ald gichtiget und si nit wainen, daz si dann sölh hächsen ald unholden sien ${ }^{7}$, daz wölten uwer fürstlichen gnauden wir nit verhalten, als die sich in uwern fürstlichen gnauden angenäm und gevälligen diensten allzit mit vlissiger undertenigkait gar gutwillig und gantz unverdrosen begerend zu bewisen und erfunden ze werden.

Datum uf fritag nach Sant Lucien tag anno domini u. LXXXIII [=17.XII.1484] uwer gnauden undertenig willige burgermaister und räte zu Rauenspurg.

6 A reference to an incubus or some kind of demonic associate.

7 Cf. II, Q.1, c.2, p. 109 [Schmidt, II, p. 37], and III, Q.15, pp. 247-8 [Schmidt, III, p. 94], where Kramer denounces the Ravensburg witch "Walburgis" who instructs women in obtaining the power of preserving silence under torture through roasting their first-born sons in an oven. 
APPENDIX C.

Promulgation of the Summis Desiderantes Affectibus

of Innocent VIII by Bishop Georg Golser of Brixen, 23 July 1484.

(Protoc. Cons. n. 194)

Reprinted in Amman,

"Der Innsbrucker Hexenprocess von 1485", pp. 78-9.

Gregorius dei gratia episcopus Brixiniensis universis et singulis abbatibus, prepositis, prioribus, decanis, vicedecanis, parrochialiumque ecclesiarum rectoribus sew loca tenentibus eorundem, vicariis perpetuis ceterisque presbiteris curatis et non curatis per civitatem et diocesim nostras ubilibet constitutis salutem in domino. Litteras sanctissimi in Christo patris et domini nostri domini Innocentii divina providentia pape octavi eius vera plumbea in filis sericeis rubei glauceique coloris impendente ballatas, sanas, integras et illesas ac omni prorsus vicio et suspicione carentes nobis pro parte venerabilis ac religiosi in Christo dilecti Heinrici Institoris ordinis fratrum predicatorum et sacre taeologie [sic] professoris ac heretice pravitatis inquisitoris principalis in eisdem litteris apostolicis principaliter nominati presentatas cum ea qua decuit reveventia recepimus sub huiusmodi tenore: "Innocentius episcopus servus servorum dei ad futuram rei memoriam. Summis desiderantes affectibus, prout pastoralis sollicitudinis cura requirit, ut fides catholica "etc.", finis vero: "Datum Rome apud Sanctum Petrum anno incarnationis dominice MCCCC octuagesimo quarto, pontificatus nostri anno primo". Post quarum quidem litterarum apostolicarum presentationem et receptionem nobis et per nos ut premittitur factam fuit nobis pro parte euisdem fratris Heinrici Institoris inquisitoris et principalis debita cum instantia supplicatum, quatenus ipsas litteras apostolicas ipsumque fratrem Heiricum ac ab eo substitutos et deputatos seu deputandos ad earundem executionem per civitatem et diocesim nostras admittere dignaremur. Unde nos supplicationibus huiusmodi ymo verius mandatis apostolicis humiliter et devote parere volentes ipsum fratrem Heinricum et alios ab eo substitutos et universos in civitate et diocesi nostris consistentes officium inquisitionis huiusmodi iuxta earundem litterarum apostolicarum formam et tenorem exequendi admisimus et tenore presentium admittimus. Vobis igitur universis et singulis aupradictis districte precipiendo etiam sub penis et censuris in ipsa bulla contentis mandamus, quatenus prefatum fratrem Heinricurn et ab eo substitutos ac substituendos, cum ad vos vel alterum 
vestrum declinaverint causa verbum dei predicandi ad effectum offitii inquisitionis aut informandi (desuper) populum, ne huiusmodi errores et demonum illusiones sequantur, benigne admittatis reverenterque recipiatis ac pertractetis. Et propterea de (omnipotentis) dei misericordia ac beatorum apostolorum Petri et Pauli auctoritate confidentes omnibus vere penitentibus et confessis, qui auxilium, favorem et qualecunque adiumentum ad inquisitionem huiusmodi zelo fidei, ut perfidia huiusmodi eradicetur, dederint, eisdem et cuilibet ipsorum quadraginta dies indulgentiarum de iniunctis eis penitentiis misericorditer in domino relaxamus. Datum Brixine sub nostri vicariatus sigillo die vigesima tertia iulii, anno domini MCCCC octuagesimo quinto. 


\section{APPENDIX D.}

\section{The Canon Episcopi.}

\section{Reprinted in:}

Russell, Witchcraft in the Middle Ages, pp. 292-3.

Ut episcopi episcoporumque ministri omnibus viribus elaborare studeant ut perniciosam et a diabolo inventam sortilegam et malificam artem penitus ex parochiis suis eradant, et si aliquem virum aut feminam huiuscemodi sceleris sectatorem invenerint, turpiter dehonestatum de parochiis suis eiciant. Ait enim Apostolus: Haereticum post unam et secundam admonitionem devita, sciens, quia subversus est, qui eiusmodi est. Subversi sunt et a diabolo capti tenentur, qui derelicto creatore suo a diabolo suffragia quaerunt. Et ideo a tali peste mundari debet sancta ecclesia. Illud etiam non omittendum, quod quaedam sceleratae mulieres (...) retro post Satanam conversae, daemonum illusionibus et phantasmatibus seductae, credunt se et profitentur nocturnis horis cum Diana paganorum dea et innumera multitudine mulierum equitare super quasdam bestias, et multa terrarum spatia intempestate noctis silentio pertransire, eiusque iussionibus velut dominae obedire, et certis noctibus ad eius servitium evocari. Sed utinam hae solae in perfidia sua perissent, et non multos secum in infidelitatis interitum pertraxissent. Nam innumare multitudo hac falsa opinione decepta haec vera esse credit, et credendo a recta fide deviat et in errorem paganorum revolvitur, cum aliquid divinitatis aut numinis extra unum esse arbitratur. Quapropter sacerdotes per ecclesias sibi commissas populo cum omni instantia praedicare debent ut noverint haec omnimodis falsa esse, et non a divino sed a maligno spiritu talia phantasmata mentibus infidelium irrogari, siquidem ipse Satanas, qui transfigurant se in angelum lucis, cum mentem cuiuscunque mulierculae ceperit et hanc sibi per infidelitatem et incredulitatem subiugaverit, illico transformat se in (...) diversarum personarum species atque similitudines, et mentem, quam captivam tenet, in somnis deludens, modo laeta, modo tristia, modo cognitas, modo incognitas personas ostendens, per devia quaeque deducit, et cum solus eius spiritus hoc patitur, infidelis mens haec non in animo, sed in corpore evenire opinatur. Quis enim non in somnis et nocturnis visionibus extra se ipsum educitur et multa videt dormiendo, quae nunquam viderat vigilando? Quis vero tam stultus et hebes sit, qui haec omnia, quae in solu spiritu fiunt, etiam in corpore accidere arbitretur? 
APPENDIX E.

The Publishing History of the Malleus Maleficarum.

The bulk of the material of this section is derived from Joseph Hansen, "Der Malleus maleficarum, seine Druckausgaben und die gefälschte Kölner Approbation vom Jahre 1487", pp. 122-33, supplemented by my own research in the University Library of Cambridge, the British Library at London, and the Staatsbibliothek in Munich. The basic numbering system used here is modelled upon Hansen.

\section{A. Undated Editions Before 1500.}

Five editions of the Malleus appeared prior to 1500 without any information concerning their time and place of publication.

I. Without any title, small folio. This edition exists in two different forms:

Ia. fol.1r blank, fol.1v apology, fol.2r list of contents; [Staatsbibliothek Munich, $2^{\mathrm{O}}$. Inc.s.a.836.a., 129 fols., attributed to Johann Preuss, Straßburg]

Ib. fol. $1 \mathrm{r}$ Summis desiderantes, fol.2r notary instrument, fol.4r blank, fol. $4 \mathrm{v}$ apology, fol.5r list of contents.

"In Ia fehlt also die Bulle und das Notariatsinstrument. Beide sind übrigens in Ib nicht ursprünglich, sondern auf drei Blättern anderen Papiers und mit andern Typen bedruckt vorgeheftet, und zwar an unrichtiger Stelle; denn die Notiz auf Bl. $3 \mathrm{~b}$ am Schlusse: 'Sequitur tabula subsequentis operis seu tractatus' beweist, dass diese drei Blätter zwischen die Appolgia und die Tabula geheftet werden sollten. Dass I wirklich als erste Ausgabe anzusehen ist, beweist das Fehlen des Titels, ferner das Fehlen der Bulle und des Instruments im ersten Zustand der Ausgabe. Die Ausgabe ist gedruckt mit den nämlichen Typen, mit denen der seit 1480 thätige Strassburger Drucker Johann Pryss der Ältere im J. 1487 den Fasciculus temporum des Werner Rolevinck druckte."

${ }^{8}$ Hansen, "Der Malleus maleficarum, seine Druckausgaben und die gefälschte Kölner Approbation vom Jahre 1487", pp. 124-5. 
II. Malleus maleficarum, small folio, fol.1r title, fol.1v apology, fol.2r Summis desiderantes, fol.2v notary instrument, fol.4r list of contents; [Staatsbibliothek Munich, $2^{\circ}$. Inc.s.a.837, 838 rubr., 102 fols., attributed to Cologne.]

The Munich copy of this edition contains the hand-written note "Anno deitatis 1491 presens liber, quem editor Malleum malleficarum intitulavit, per Ulricum Ruden est emptus pro dimidio floreno Renensi, et industria et arte domini Petri Jaeger de Aw, rectoris ecclesie in Otting, illigatus anno etc. 94"; Hansen thus concludes that it was thus available at the booksellers already in 1491 and must have been printed before that year. ${ }^{9}$

III. Malleus maleficarum, $4^{\mathbf{0}}$, fol.1r title, fol.1v blank, fol.2r apology, fol.3r Summis desiderantes, fol.4v notary instrument, fol.7r list of contents; [Staatsbibliothek Munich, 40. Inc.s.a.1199, 190 fols., attributed to Cologne.]

IV. Malleus maleficarum, $8^{0}$, fol.1r title, fol.1v blank, fol.2r apology, fol.3a Summis desiderantes, fol.5v notary instrument, fol.9b list of contents; [Staatsbibliothek Munich, $8^{0}$. Inc.s.a.160, 303 fols., attributed to Cologne.]

V. Malleus maleficarum maleficas et earum heresim ut phrames potentissima conterens. Venundatur vico divi Jacobi sub Lilio aureo et leone argenteo ab Joanne Parvo, [Paris], $8^{0}$, fol.1r title, fol.1v woodcut, fol.2r apology, fol.2v Summis desiderantes, fol.4r notary instrument, fol.6v list of contents.

Note: The Catalogue of the British Library lists three early, undated editions of the Malleus - IB. 8581, IB. 8615, IA. 8634. All three are attributed to the printing press of Peter Drach of Speyer. Although it is difficult to establish with certitude these incunabula may well be the unspecified editions II to IV.

\section{B. Dated Editions Before 1500 .}

VI. Malleus Maleficarum. Nürnberg, 17 March 1494.

This edition includes the following print information: "Anno deitatis 1494 presens liber, quem editor Malleum malleficarum intitulavit, per Antonium Koberger Nurbergensem civem est impressus et ad hunc finem perductus 17. die

9 Ibid., pp. 125, 125-6. 
mensis Marcii."

VII. Malleus Maleficarum. Cologne, 24 November 1494.

This edition includes the following print information: "Liber Malleus maleficarum a suo editore nuncupatus impressusque per me Joannem Koelhoff incedam civitatis sancte Coloniensis anno salutis 1494 in vigilia s. Katherine regine ac virginis martyrisque finem accepit feliciter."

VIII. Malleus Maleficarum. Nürnberg, 17 January 1496.

This edition includes the following print information: "Anno deitatis 1496 presens liber, quem editor Malleum malleficarum intitulavit, per Anthonium Koberger Nurembergensem civem est impressus et ad hunc finem perductus 17 . die mensis Januarii."

\section{Editions from 1500 to 1669 .}

IX. Malleus maleficarum. Cologne, Heinrich of Neuss, 1511.

X. Malleus maleficarum maleficas et earum heresim ut phramea potentissima conteres. Lyon, Johann Marion, 23 February 1519.

XI. Malleus maleficarum opus egregium de variis incantationum generibus origine, progressu, modela atque ordinaria damnatione, compilatus ab eximiis Heinrico Institoris et Jacobo Sprenger ordinis Predicatorum, sacre pagine doctoribus et heretice pestis inquisitoribus, non tam utilis quam necessarius. Eme, lege nec te precii penitebit. Nürnberg, Friedrich Peypus, August 1519.

XII. Malleus maleficarum opus egregium de variis incantationum generibus origine, progressu, modela atque ordinaria damnatione, compilatus $a b$ eximiis Heinrico Institoris et Jacobo Sprenger ordinis Predicatorum, sacre pagine doctoribus et heretice pestis inquisitoribus, non tam utilis quam necessarius. Eme, lege nec te precii penitebit. Nürnberg, Friedrich Peypus, 1520.

XIII. Malleus maleficarum maleficas at earum haeresim ut phramea potentissima conterens. Cologne, Joannes Gymnicus, 1520.

XIV. Malleus maleficarum in tres divisus partes, in quibus concurrentia ad maleficia, maleficiorum effectus, remedia adversus maleficia et modus denique procedendi ac puniendi maleficos abunde continetur [...], 
auctore r.p. Fr. Jacobo Sprenger [...] Hac postrema editione per F. Raffaelem Maffeum Venetum, d. Jacobi a Judeca instituti Servorum, summo studio illustratus et a multis erroribus vindicatus. Venice, Jo. Ant. Bertanus (ad candentis Salamandrae insigne) 1574.

XV. Malleus maleficarum in tres divisus partes, in quibus concurrentia ad maleficia, maleficiorum effectus, remedia adversus maleficia et modus denique procedendi ac puniendi maleficos abunde continetur [...], auctore r.p. Fr. Jacobo Sprenger [...] Hac postrema editione per F. Raffaelem Maffeum Venetum, d. Jacobi a Judeca instituti Servorum, summo studio illustratus et a multis erroribus vindicatus. Venice, Jo. Ant. Bertanus (ad candentis Salamandrae insigne) 1576.

XVI. Malleus maleficarum in tres divisus partes, in quibus concurrentia ad maleficia, maleficiorum effectus, remedia adversus maleficia et modus denique procedendi ac puniendi maleficos abunde continetur [...l, auctore r.p. Fr. Jacobo Sprenger. Frankfurt a.M., Nicolaus Bassaeus, 1580 .

XVII. Malleus Maleficarum, de lamiis et strigibus, et sagis, aliisque magis \& daemoniacis, eorumque; arte, \& potestate \& poena, Tractatus aliquot tam veterum, quam recentiorum auctorum: in tomos duos distributi. Frankfurt a.M., 1582.

XVIII. Malleus maleficarum ex plurimus authoribus coarcervatus ac in duos tomos distinctus. Ioannem Jacobi Iuntae, Lyon, 1584.

XIX. Malleorum quorundam maleficarum tam veterum quam recentiorum autorum tomi duo. Frankfurt a.M., 1588.

XX. Malleus Maleficarum, 2 vols., Petrus Landry, Lyon, 1595.

XXI. $\quad$ Malleus Maleficarum, Freiburg, 1598.

XXII. Malleorum quorundam maleficarum tam veterum quam recentiorum autorum tomi duo. Frankfurt a.M., Nic. Bassaeus, 1600.

XXIII. Malleus maleficarum ex variis auctoribus concinnatus et in tres tomos distinnctus, quorum postremus, qui Fustis daemonum inscribitur, nunc primum reliquis adiectus est. Lyon, Petrus Landry, 1604.

XXIV. Malleus maleficarum ex variis auctoribus concinnatus et in tres tomos 
distinctus, quorum postremus, qui Fustis daemonum inscripitur, nunc primum adiectus est, cum Fuga Satanae. Lyon, Petrus Landry, 1615 (Vol.I and II Part I), and Lyon, Claudius Landry, 1620-1 (Vol. II Part II).

XXV. Malleus maleficarum, maleficas et earum haeresim framea conterens, ex variis auctoribus compilatus et in quatuor tomos iuste distributus. Lyon, Claudius Bourgeat, 1669.

D. Contemporary Editions.

XXVI. Schmidt, J.W.R. (ed.), Jakob Sprenger, Heinrich Institoris: Der Hexenhammer (Malleus Maleficarum), transl. and with an introduction by J.W.R. Schmidt, 3 Parts, Berlin, 1906.

XXVII. Schmidt, J.W.R. (ed.), Der Hexenhammer, von Jakob Sprenger und Heinrich Institoris, zum ersten Male ins Deutsche übertragen nach der lateinischen Ausgabe aus dem Jahre 1439 [sic], transl. by J.W.R. Schmidt, 3 Parts, Berlin, 1923.

XXVIII. Summers, Montague (ed.), The Malleus Maleficarum, by Jakob Sprenger and Heinrich Institoris, transl. with an introduction, bibliography and notes by M. Summers, London (John Rodker), 1928.

XXIX. Summers, Montague (ed.), The Malleus Maleficarum, by Jacob Sprenger and Heinrich Institoris, transl. with an introduction, bibliography and notes by M. Summers, London (The Pushkin Press), 1948.

Reprinted 1951, 1969 (Hogarth Press).

XXX. Hughes, Pennethorne (ed.), James Sprenger and Heinrich Institoris, The Malleus Maleficarum, transl. by Montague Summers and ed. with an introduction by P. Hughes, London (The Folio Society), 1968.

XXXI. Malleus maleficarum, maleficas et earum haeresim framea conterens, ex variis auctoribus compilatus, \& in quatuor tomos iuste distributus, Lugundi (Lyon), Bourgeat, 1669, Reprint Brussel, Culture et Civilisation, 1969.

XXXII. Summers, Montague (ed.), Heinrich Kramer \& James Sprenger, The Malleus Maleficarum, transl. by M. Summers, London (Arrow Books), 1971.

Reprinted 1986. 
XXXIIII. Summers, Montague (ed.), The Malleus Maleficarum of Heinrich Kramer and James Sprenger, transl. with introductions, bibliography and notes by Rev. M. Summers, New York (Dover Publications), 1971. (Reprint of the 1928 John Rodker edition with Summers' introduction to the 1948 Pushkin Press edition.)

XXXIIII. Danet, Amand (ed.), Le marteau des sorcières [par] Henry Institoris (Kraemer) et Jacques Sprenger, ed. and transl. by A. Danet (Civilisations et mentalités), Paris, 1973.

XXXIV. Holdridge, Barbara (ed.), Malleus Maleficarum by Heinrich Kramer and James Sprenger, Phonodisc, transl. by M. Summers, abridged by Barbara Holdridge and read by Ian Richardson, Caedmon TC 1434, 1974.

XXXV. Heinrich Institor (Krämer), Jakob Sprenger, Il martello delle streghe. La sessualità femminile nel transfert degli inquisitori, transl. by $F$. Buia with an introduction by A. Verdiglione (Semiotica e psicanalisi, 7), Rome, 1977.

XXXVI. J.W.R. Schmidt (ed.), Jakob Sprenger, Heinrich Institoris, Der Hexenhammer (Malleus maleficarum), transl. and with an introduction by J.W.R. Schmidt, Darmstadt (Wissenschaftliche Buchgesellschaft), 1980. (Reprint of the 1906 edition of J.W.R. Schmidt), also reprinted in Munich (Deutscher Taschenbuch Verlag), 1987. 


\section{BIBLIOGRAPHY。}

\section{A. Manuscript Sources.}

Ravensburg

$\begin{array}{ll}\text { Stadtarchiv: Urfehden Nos. } & \text { U. } 1116 \\ & \text { U. } 1119 \\ & \text { U. } 1129 \\ & \text { U. } 1131\end{array}$

B. Printed Sources.

Alexander IV,

Quod super nonnullis, in: Quellen und Untersuchungen zur Geschichte des Hexenwahns und der Hexenverfolgung im Mittelalter, ed. by Joseph Hansen, Hildesheim, 1963, p.1.

Anonymus,

Errores Gazariorum, in: Quellen und Untersuchungen zur Geschichte des Hexenwahns und der Hexenverfolgung im Mittelalter, ed. by Joseph Hansen, Hildesheim, 1963, 118-22.

Anonymus,

Recollectio, in: Quellen und Untersuchungen zur Geschichte des Hexenwahns und der Hexenverfolgung im Mittelalter, ed. by Joseph Hansen, Hildesheim, 1963, 149-83.

Anonymus,

"La Vaudenge de Lyonis en brief", in: Quellen und Untersuchungen zur Geschichte des Hexenwahns und der Hexenverfolgung im Mittelalter, ed. by Joseph Hansen, Hildesheim, 1963, 188-95.

Aquinas, Thomas,

Expositio in Ioannem, in: Catena Aurea in Quatuor Evangelia, II. Expositio in Lucam et loannem, Rome, 1953, 323-593. 
Aquinas, Thomas,

De Malo, in: Quaestiones Disputatae, Vol. 2, Rome, 1965, 439-669.

Aquinas, Thomas,

In Secundum Librum Sententiarum Magistri Petri Lombardi cuius Distinctiones, ac Quaestiones sequens ostendit Index, Venice, 1586.

Aquinas, Thomas,

Liber de Veritate Catholicae Fidei contra errores Infidelium seu Summa Contra Gentiles, Vol. 3, ed. by Ceslai Pera, D. Petro Marc and D. Petro Caramello, Rome, 1961.

Aquinas, Thomas,

Summa Theologiae, Pars Prima et Prima Secundae, ed. by D. Petro Caramello, Rome, 1952.

Aquinas, Thomas,

Summa Theologiae, Pars Secunda Secundae, ed. by Petro Caramello, Rome, 1962.

Augustine,

De Civitate Dei Contra Paganos, Vol. 2, ed. with an introduction and appendices by J.E.C. Welldon, London, 1924.

Augustine,

De Doctrina Christiana, in: Sancti Aurelii Augustini Opera, Sect. VI, Pars VI, ed. by William M. Green, Vindobonae, 1963.

Carolina,

Die Peinliche Gerichtsordnung Kaiser Karls V. von 1532 (Carolina), ed. by Gustav Radbruch, Stuttgart, 1967.

Cassetta, Salvus,

Registrum litterarum Salvi Cassettae 1481-1483. Barbabae Saxoni 1486, ed. by Benedictus Maria Reichert, (Quellen und Forschungen zur Geschichte des Dominikanerordens in Deutschland, 7), Leipzig, 1912.

Cassinis, Samuel de,

Question de le strie, Questio lamiarum, in: Quellen und Untersuchungen zur Geschichte des Hexenwahns und der Hexenverfolgung im Mittelalter, ed. by Joseph Hansen, Hildesheim, 1963, 263-73. 
Die Chroniken der deutschen Städte vom 14. bis in 16. Jahrhundert,

Vierzehnter Band: Die Chroniken der Niederrheinischen Städte: Cöln, Vol. 3, ed. Historische Commission bei der Königlichen Academie der Wissenschaften, Leipzig, 1877.

Como, Bernard of,

Tractatus de strigiis, in: Quellen und Untersuchungen zur Geschichte des Hexenwahns und der Hexenverfolgung im Mittelalter, ed. by Joseph Hansen, Hildesheim, 1963, 279-84.

Conclusio facultatis theologie super materia fidei nunc agitata novissime determinata de superstitionibus, 1398 Septem. 19, Parisiis,

in: Chartularium Universitatis Parisiensis, Vol. 4, ed. by H. Denifle and

A. Chatelain, Paris, 1897, 32-5.

Dodo of Paria, Vincenz,

"Apologia", in: Quellen und Untersuchungen zur Geschichte des Hexenwahns und der Hexenverfolgung im Mittelalter, ed. by Joseph Hansen, Hildesheim, 1963, 273-8.

Eugenius IV,

Decretal, in: Quellen und Untersuchungen zur Geschichte des Hexenwahns und der Hexenverfolgung im Mittelalter, ed. by Joseph Hansen, Hildesheim, 1963, 17-18.

Eymeric, Nicholas,

Directorium Inquisitorum. Cum Commentariis Francisci Peniae Sacrae Theologiae ac Iuris Utriusque Doctoris, Venice, 1595.

Flamborough, Robert of,

Liber Penitentialis, ed. by J.F. Firth, Toronto, 1971.

Gerson, Jean,

De erroribus circa artem magicam, in: Oeuvres complètes, Vol. 10, Paris, 1973, 77-90.

Gui, Bernard,

Practica Inquisitionis Heretice Pravitatis, ed. by C. Douais, Paris, 1886.

Hartzheim, Joseph, (ed.),

Bibliotheca Coloniensis, in qua vita et libri typo vulgati et manuscripti

recensentur omnium archidioeceseos Coloniensis, Köln, 1747. 
Hartzheim, Joseph, (ed.),

Prodromus Historiae Universitatis Coloniensis; quo exhibetur synopsis actorum et scriptorum a Facultate Theologica pro Ecclesia Catholica et Republica, Vol. 1, Cologne, 1759.

Heisterbach, Caesarius,

The Dialogue on Miracles, transl. by H. von E. Scott and C.C.S. Bland, 2 vols., London, 1929.

Hutten, Ulrich,

Ulrici Hutteni, Opera quae reperiri potuerunt omnia, ed. by Eduard Böcking, Supplement 1, [no place of publication], 1859.

Institoris, Heinrich,

Epistola contra quendam Conciliistam Archiepiscopum Crainensem, Schlettstadt, 10 August 1482.

Institoris, Heinrich,

Jakob Sprenger, Heinrich Institoris. Der Hexenhammer (Malleus Maleficarum), transl. and ed. by J.W.R. Schmidt, Munich [Deutscher Taschenbuch Verlag], 1987.

Institoris, Heinrich,

Malleus Maleficarum, Maleficas et Earum haeresim framea conterens, ex variis auctoribus compilatus, \& in quatuor [sic] Tomos iuste distributus. Tomus Primus, Lyon [Claudii Bourgeat], 1669.

Institoris, Heinrich,

The Malleus Maleficarum of Heinrich Kramer and James Sprenger, transl. with introductions, bibliography and notes by Rev. Montague Summers, New York [Dover Publications], 1971.

Institoris, Heinrich,

Opusculum in errores Monarchiae, Venice, 27 July 1499.

Institoris, Heinrich,

Sancte Romane Ecclesie Fidei Defensionis Clypeus adversus Waldensium seu Pickardorum Heresum, Olmütz, 20 March 1502.

Institoris, Heinrich,

Tractatus novus de miraculoso eucariste sacramento, quando apparet in forma pueri aut carnis vel sanguis in hostia consecrata, [no place of 
publication], 1496.

Institoris, Heinrich,

Tractatus varii cum sermonibus plurimus contra quattor errores novissime exortos adversus divinissimum euchariste sacramentum: collecti a lectore ecclesie Saltzburgen. A.D. 1495. 11 Augusti Augsburg, Nürnberg, 26 January 1496.

Jacquier, Nicholas, Flagellum Haereticorum Fascinariorum, Frankfurt am Main, 1581.

Mamoris, Peter, Flagellum Maleficorum, in: Malleus Maleficarum, Daemonastix, seu Adversus Daemones et Maleficos, universi operis ad usum praesertim Exorcistarum concinnati. Tomus Tertius, Lyon, 1669.

Molitor, Ulrich,

Tractatus Utilis et Necessarius, per Viam Dialogi, de Pythonicis mulieribus, in: Mallei Maleficarum Tractatus Aliquot tam uterum, quam Recentiorum in unum corpus coacervati, Artis Magicae Stupendos Affectus, Lamiarum Pythonicos contractus, impia dogmata, spurcitias, fascinationes, veneficiaque demonstrantis. Tomi Secundi Pars, Lyon, 1669, 17-45.

Nider, Johannes,

Formicarium, Duaci, 7 June 1602.

Nider, Johannes,

Praeceptorium: Sive Orthodoxa et Accuratu Decalogi Explicatio, Duaci, 1611.

Prierias, Silvester,

De Strigimagorum, Daemonumque Mirandis, Libri Tres, Rome, 1575.

Prüm, Regino of,

Canon Episcopi, reprinted in: Jeffrey Burton Russell, Witchcraft in the Middle Ages, Ithaca, 1972, 291-3.

de Spina, Bartholomus,

Quaestio de Strigibus, in: Tomus Secundus Malleorum Quorundam

Maleficarum, Frankfurt a.M., 1588, 452-619. 
[Sprenger, Jacob],

Examen Magistrale ac theologicale doctoris Ioannis de Vvesalia concionatoris Vuormaciensis, praesidentibus Magistris Nostris haereticae pravitatis inquisitoribus M.N. Gerhardo Elten, \& Iacobo Sprenger de ordine Praedicatorum, in: Commentariorum Aeneae Sylvii Piccolominei Senensis, de Concilio Basileae celebrato libro duo, olim quidem scripti, nunc vero primum impressi, Basel, 1530-40, 337-44.

Sprenger, Jacob,

Paradoxa de Ioannis de Vvesalia Sacrarum literarum doctoris, ac concionatoris Vuormiciensis, quae feruntur a quibusdam Thomistis ex illius concionantis ore fuisse excepta: mox damnata per Magistros Nostros haereticae pravitatis inquisitores, de ordine Praedicatorum M.N. Gerhardum Elten de Colonia, \& M.N. Iacobum Sprenger, in: Commentariorum Aeneae Sylvii Piccolominei Senensis, de Concilio Basileae celebrato libro duo, olim quidem scripti, nunc vero primum impressi, Basel, 1530-40, 335-6.

Sprenger, Jacob,

Statuten der Rosenkrantz Bruderschafft, Augsburg, 1476.

Statuta seu Decreta Provincialium et Dioecesanarum synodorum Sanctae Ecclesiae Coloniensis, Cologne, March 1534.

Tinctoris, Johann,

Tractatus de secta Vaudensium, in: Quellen und Untersuchungen zur Geschichte des Hexenwahns und der Hexenverfolgung im Mittelalter, ed. by Joseph Hansen, Hildesheim, 1963, 183-8.

Tostatus, Alphons,

"Bibelkommentar", in: Quellen und Untersuchungen zur Geschichte des Hexenwahns und der Hexenverfolgung im Mittelalter, ed. by Joseph Hansen, Hildesheim, 1963, 105-9.

Trithemius, Johannes,

Liber octo questionum, quas illi dissolvendas proposuit Maximilianum cesarem, Cologne, 1534.

Visconti, Girolamo,

Lamiarum sive striarum opusculum, in: Quellen und Untersuchungen zur Geschichte des Hexenwahns und der Hexenverfolgung im Mittelalter, ed. by Joseph Hansen, Hildesheim, 1963, 200-7. 
Worms, Burchard of,

"Selections from the Corrector and Physician of Burchard of Worms (ca. 1008-120", in: Medieval Handbooks of Penance, ed. and transl. by John T. McNeill and Helena Gamer, New York, 1938, 321-45.

\section{Printed Secondary Works.}

Allers, Rudolf,

"Microcosmus from Anaximandros to Paracelsus", Traditio, 1 (1943), 319407.

Allgemeine Deutsche Biographie, ed. by Historische Commission bei der Königlichen Akademie der Wissenschaften, Leipzig, 1883.

Amman, Hartmann,

"Der Innsbrucker Hexenprocess von 1485", Zeitschrift des Ferdinandeums für Tirol und Vorarlberg, ser. 3, 34 (1890), 1-87.

Amman, Hartmann,

"Eine Vorarbeit des Heinrich Institoris für den Malleus Maleficarum", Mitteilungen des Instituts für Österreichische Geschichte, Supplement 8 (1911), 461-504.

Anglo, Sydney,

"Evident Authority and Authoritative Evidence: The Malleus Maleficarum", in: The Damned Art: Essays in the Literature of Witchcraft, ed. by Sydney Anglo, London, 1977, 1-31.

Ankarloo, Bengt, and Gustav Hennigsen,

Early Modern European Witchcraft: Centres and Peripheries, Oxford, 1990.

Arnold, Klaus,

"Hexenglaube und Humanismus bei Trithemius (1462-1516)", in: Der Hexenhammer: Entstehung und Umfeld des Malleus Maleficarum von 1487, ed. by Peter Segl, (Bayreuther Historische Kolloquien, 2), Köln, 
$1988,217-40$.

Artz, Frederick B.,

The Mind of the Middle Ages A.D. 200-1500: An Historical Survey, Chicago, 1983.

Baldwin, John W.,

"The Intellectual Preparation for the Canon of 1215 Against Ordeals", Speculum, 36 (1961), 613-36.

Barber, Malcolm,

"Lepers, Jews and Moslems: The Plot to Overthrow Christendom in 1321", History, 66 (1981), 1-17.

Barber, Malcolm,

The Trial of the Templars, Cambridge, 1980.

Baroja, Julio Caro,

The World of the Witches, Chicago, 1965.

Bartlett, Robert,

Trial by Fire and Water: The Medieval Judicial Ordeal, Oxford, 1988.

Baum, Wilhelm,

Sigmund der Münzreiche, Bozen, 1987.

Bauman, Zygmunt,

Memories of Class, London, 1982.

Behringer, Wolfgang,

Hexenverfolgungen in Bayern: Volksmagie, Glaubenseifer und Staatsräson in der Frühen Neuzeit, München, 1987.

Benton, John F.

"Consciousness of Self and Perceptions of Individuality", in: Renaissance and Renewal in the Twelfth Century, ed. by Robert L. Benson and Giles Constable, Oxford, 1985.

Bernard, Paul P.

"Heresy in Fourteenth-Century Austria", Medievalia et Humanistica, 10 (1956), 50-63. 
Bever, Edward,

"Old Age and Witchcraft in Early Modern Europe", in: Old Age in Preindustrial Society, ed. by Peter N. Stearns, New York, 1982, 150-90.

Bianco, Franz Joseph von,

Die alte Universität Köln und die spätern Gelehrten-Schulen dieser Stadt, Part I, Köln, 1855.

Blauert, Andreas,

Frühe Hexenverfolgungen: Ketzer-, Zauberei- und Hexenprozesse des 15. Jahrhunderts, Hamburg 1989.

Bolton, Brenda,

The Medieval Reformation, London, 1983.

Briggs, Robin,

"Witchcraft and Popular Mentality in Lorraine: 1580-1630", in: Occult and Scientific Mentalities in the Renaissance, ed. by Brian Vickers, Cambridge, 1984, 337-49.

Brody, Saul Nathaniel, The Disease of the Soul: Leprosy in Medieval Literature, Ithaca, 1974.

Brown, Peter,

Augustine of Hippo, Berkeley, 1969.

Brown, Peter,

"Society and the Supernatural: A Medieval Change", Daedalus, 104 (1975), 133-1.

Brown, Peter,

"Sorcery, Demons and the Rise of Christianity from Late Antiquity into the Middle Ages", in: Peter Brown, Religion and Society in the Age of St. Augustine, London, 1972, 119-46.

Brucker, Gene A.,

"Sorcery in Early Renaissance Florence", Studies in the Renaissance, 10 (1963), 7-24.

Brundage, James A.

Law, Sex, and Christian Society in Medieval Europe, Chiicago, 1987. 
de Bruyn, Lucy,

Woman and the Devil in Sixteenth-Century Literature, Wiltshire, 1979.

Bullough, Vern L.,

"Postscript: Heresy, Witchcraft, and Sexuality", in: Sexual Practices and the Medieval Church, ed. by Vern L. Bullough and James A. Brundage, New York, 1982, 206-17.

Burghartz, Susanna,

"The Equation of Women and Witches: A Case Study of Witchcraft Trials in Lucerne and Lausanne in th Fifteenth and Sixteenth Centuries", in: The German Underworld: Deviants and Outcasts in German History, ed. by Richard J. Evans, New York, 1988, 57-74.

Burmann, Edward,

The Templars: Knights of God, Crucible/Great Britain, 1986.

Burr, George L.,

"The Literature of Witchcraft", American Historical Association Papers, 4 (1890), 37-66.

Byloff, Fritz,

Hexenglaube und Hexenverfolgung in den österreichischen Alpenländern, '(Quellen zur Deutschen Volkskunde, 6), Berlin, 1934.

van Caenegam, R.C,

"La Preuve dans le Droit du Moyen Age Occidental: Rapport de Synthèse", La Preuve, Vol. 17, 1965, 691-755.

Catalogue of Books Printed in the XVth Century now in the British Museum, Part 2, Germany, Eltvil-Trier, London 1912.

Clark, Stuart,

"Inversion, Misrule and the Meaning of Witchcraft", Past and Present, 87 (1980), 98-127.

Clark, Stuart,

"The Scientific Status of Demonology", in: Occult and Scientific Mentalities in the Renaissance, ed. by Brian Vickers, Cambridge, 1986, 351-74. 
Cohn, Norman,

Europe's Inner Demons, St. Albans, 1975.

Copenhaver, Brian,

"Hermes Trismegistus, Proclus, and the Question of a Philosophy of Magic in the Renaissance", in: Hermeticism in the Renaissance: Intellectual History and the Occult in Early Modern Europe, ed. by Ingrid Merkel and Allen G. Debus, London, 1988, 79-109.

Cruel, Rudolf,

Geschichte der Deutschen Predigt im Mittelalter, Darmstadt, 1966.

Daly, Mary,

Gyn/Ecology: The Metaethics of Radical Feminism, London, 1978.

Deane, Herbert A.,

The Political and Social Ideas of St. Augustine, New York, 1963.

Delumeau, Jean,

Catholicism Between Luther and Voltaire: A New View of the Counter-

Reformation, London, 1977.

Dienst, Heide,

"Lebensbewältigung durch Magie: Alltägliche Zauberei in Innsbruck gegen Ende des 15. Jahrhunderts", in: Alltag im 16. Jahrhundert: Studien zu Lebensformen in Mitteleuropäischen Städten, (Wiener Beiträge zur Geschichte der Neuzeit, 14), 1987, 80-116.

Dienst, Heide,

"Magische Vorstellungen und Hexenverfolgungen in den Österreichischen Ländern (15. bis 18. Jahrhundert)", in: Wellen der Verfolgung in der Österreichischen Geschichte, (Schriften des Institutes für Österreichkunde, 48), 1986, 70-94.

Dondaine, Antonie,

"Le Manuel de l'Inquisiteur (1230-1330)", Archivum Fratrum Praedicatorum, 17 (1974), 85-194.

Donzelot, Jacques,

The Policing of Families, London, 1980. 
Douglas, Mary,

Purity and Danger: An Analysis of the Concepts of Pollution and Taboo, London, 1984.

Dreyfus, Herbert, and Paul Rabinow, Michel Foucault: Beyond Structuralism and Hermeneutics, Brighton, 1986.

Dresden-Coenders, Lène,

"Witches as Devil's Concubines: On the Origin of Fear of Witches and Protection against Witchcraft", in: Saints and She-Devils: Images of Women in the 15th and 16th Centuries, ed. by Lène Dresden-Coenders, London, 1987, 59-82.

Easlea, Brian,

Witch-Hunting, Magic and the New Philosopphy: An Introduction to Debates of the Scientific Revolution 1450-1750, Sussex, 1980.

Eckermann, Karla,

Studien zur Geschichte des Monarchischen Gedankens im 15. Jahrhundert, (Abhandlungen zur Mittleren und Neueren geschichte, 73), BerlinGrunewald, 1933.

Eckstein, F.,

"Zum Diersburger Hexenprozess vom Jahre 1486", Zeitschrift für die Geschichte des Oberrheins, 40 (1927), 635-6.

Emmerson, Richard Kenneth,

Antichrist in the Middle Ages: A Study of Medieval Apocalypticism, Art, and Literature, Manchester, 1981.

Endres, Rudolf,

"Heinrich Institoris, sein Hexenhammer und der Nürnberger Rat", in: Der Hexenhammer: Entstehung und Umfeld des Malleus Maleficarum von $\underline{1487}$, ed. by Peter Segl (Bayreuther Historische Kolloquien, 2), Köln, 1988, 196-216.

Ennen, Leonard (ed.),

Katalog der Inkunabeln in der Stadt-Bibliothek zu Köln, "Erste Abtheilung", Köln, 1865.

Estes, Leland,

"The Medical Origins of the European Witch Craze: A Hypothesis", The 
Journal of Social History, 17 (1983), 271-84.

Evans, R.J.W.,

The Making of the Habsburg Monarchy 1550-1700: An Interpretation, Oxford, 1979.

Evans-Pritchard, E.E.,

"Sorcery and Native Opinion", in: Witchcraft and Sorcery: Selected

Readings, ed. by Max Marwick, 2nd edn., Harmondsworth, 1982, 23-8.

Evans-Pritchard, E.E.,

Witchcraft, Oracles, and Magic among the Azande, Abridged by Eva Gillies, Oxford, 1983.

Fehr, Hans,

Deutsche Rechtsgeschichte, Berlin, 1962.

Foucault, Michel,

The Archaeology of Knowledge and the Discourse on Language, New York, 1972.

Foucault, Michel,

"The Confession of the Flesh", in: Power/Knowledge: Selected Interviews and Other Writings 1972-77, ed. by Colin Gordon, Brighton, 1980.

Foucault, Michel,

Discipline and Punish: The Birth of the Prison, Harmondsworth, 1985.

Foucault, Michel,

The History of Sexuality, Vol. 1: An Introduction, Harmondsworth, 1984.

Foucault, Michel,

"Politics and the Study of Discourse", Ideology and Consciousness, 3 (1978), 7-26.

Foucault, Michel,

"Afterword: The Subject and Power", in: Herbert L. Dreyfus and Paul Rabinow, Michel Foucault: Beyond Structuralism and Hermeneutics, Brighton, 1986, 208-26.

Foucault, Michel,

"What is an Author?", in: Language, Counter-Memory, Practice: Selected 
Essays and Interviews, ed. by Donald F. Bouchard, Ithaca, 19986, 113-38.

Frank, I.,

"Geschichte des Wortes Hexe", in: Quellen und Untersuchungen zur Geschichte des Hexenwahns und der Hexenverfolgung im Mittelalter, ed. by Joseph Hansen, Hildesheim, 1963, 614-70.

Franken, Irene, and Ina Hoerner, Hexen: Die Verfolgung von Frauen in Köln, Köln 1987.

Garrett, Clarke,

"Witches and Cunning Folk in the Old Regime", in: The Wolf and the Lamb: Popular Culture in France from the Old Regime to the Twentieth Century, ed. by Jacques Beauroy, Marc Bertrand, Edward T. Gargan (Stanford French and Italian Studies, 3), Stanford, 1977.

Garrett, Clarke,

"Women and Witches: Patterns of Analysis", Signs, 3 (1977-8), 461-70.

Gellrich, Jesse M., The Idea of the Book in the Middle Ages: Language Theory, Mythology, and Fiction, Ithaca, 1985.

Gifford, Edward Stewart, The Evil Eye: Studies in the Folklore of Vision, New York, 1958.

Ginzburg, Carlo, Hexensabbat: Entzifferung einer Nächtlichen Geschichte, transl. by Martina Kempter, Berlin, 1990.

Ginzburg, Carlo, The Night Battles: Witchcraft and Agrarian Cults in the Sixteenth and Seventeenth Centuries, London, 1983.

Ginzburg, Carlo, "The Witches' Sabbat: Popular Cult or Inquisitorial Stereotype?", in: Understanding Popular Culture: Europe from the Middle Ages to the Nineteenth Century, ed. by Steven L. Kaplan (New Babylon Studies in the Social Sciences), New York, 1985, 39-51.

Given, James,

"The Inquisitors of Languedoc and the Medieval Technology of Power", 
The American Historical Association, 94 (1989), 336-59.

Grabmann, Martin,

Die Geschichte der Scholastischen Methode, Vol. 1: Die Scholastische Methode von Ihren Anfängen in der Väterliteratur bis zum Beginn des 12. Jahrhunderts, Freiburg im Breisgau, 1909.

Grimm, Jakob,

Deutsche Mythologie, Vol. 3, Berlin, 1875.

Grimm, Jacob und Wilhelm,

"Selig-Seligen", Deutsches Wörterbuch, Vol. 10, Leipzig, 1905, 527.

Grotefend,

"Hexen in Frankfurt", Mittheilungen des Vereins für Geschichte und Alterthumskunde in Frankfurt a.M., 6 (1881), 70-8.

Gurevich, Aron, Medieval Popular Culture: Problems of Belief and Perception, transl. by Janos M. Bak and Paul A. Hollingsworth, (Cambridge Studies in Oral and Literate Culture, 14), Cambridge, 1988.

Hafner, T. (ed.),

Geschichte der Stadt Ravensburg nach Quellen und UrkundenSammlungen, Ravensburg, 1887.

Hamilton, Bernard, The Medieval Inquisition, London, 1981.

Hansen, Bert, "Science and Magic", in: Science in the Middle Ages, ed. by David C. Lindberg, Chicago, 1978, 483-506.

Hansen, Joseph,

"Heinrich Institoris, der Verfasser des Hexenhammers, und seine Tätigkeit an der Mosel im Jahre 1488", Westdeutsche Zeitschrift für Geschichte und Kunst, 26 (1907), 110-18.

Hansen, Joseph,

"Der Hexenhammer, seine Bedeutung und die gefälschte Kölner Appprobation vom Jahre 1487", Westdeutsche Zeitschrift für Geschichte und Kunst, 26 (1907), 372-404. 
Hansen, Joseph,

"Zur Kontroverse über den Hexenhammer und seine Kölner Approbation vom Jahre 1487", Westdeutsche Zeitschrift für Geschichte und Kunst, 27 (1908), 366-72.

Hansen, Joseph,

Quellen und Untersuchungen zur Geschichte des Hexenwahns und der Hexenverfolgung im Mittelalter, Hildesheim, 1963.

Hansen, Joseph,

"Der Malleus maleficarum, seine Druckausgaben und die gefälschte Kölner Approbation vom Jahre 1487", Westdeutsche Zeitschrift für Geschichte und Kunst, 17 (1898), 119-68.

Hansen, Joseph,

Zauberwahn, Inquisition und Hexenprozess im Mittelalter und die Entstehung der Großen Hexenverfolgung (Historische Bibliothek, 12), München, 1900.

Harland, Richard,

Superstructuralism: The Philosophy of Structuralism and PostStructuralism, London, 1987.

Harleý, David,

"Historians as Demonologists: The Myth of the Midwife-witch", $\underline{\text { Social }}$ History of Medicine, 3 (1990), 1-26.

Harris, Marvin,

Cows, Pigs, Wars and Witches: The Riddles of Culture, London, 1975.

Heberling, Richard,

"Zauberei und Hexenprozesse in Schleswig-Holstein-Lauenburg: Auf Grund des Aktenmaterials im Kgl. Staatsarchiv Schleswig", Zeitschrift der Gesellschaft für Schleswig-Holsteinische Geschichte, Vol. 45, Leipzig, 1919, 216-46.

von Hehl, Ulrich,

"Die Hexenprozesse der Frühen Neuzeit: Rheinische Aspekte eines Europäischen Phänomens", in: Festgabe Heinz Hürten zum 60. Geburtstag, ed. by Harold Dickerhof, Frankfurt a.M., 1988, 243-64. 
von Hehl, Ulrich,

"Hexenprozeß und Geschichtswissenschaft", Historisches Jahrbuch, 107 (1987), 349-75.

Henningsen, Gustav, The Witches' Advocate: Basque Witchcraft and the Spanish Inquisition 1609-1614, Reno, 1980.

Hirst, Paul and Penny Wooley, Social Relations and Human Attributes, London, 1982.

Hobsbawm, Eric,

Bandits, Harmondsworth, 1972.

Hoffman-Krayer, E.,

"Luzerner Akten zum Hexen- und Zauberwesen", Schweizerisches Archiv für Volkskunde, 3 (1899), 22-40, 82-122, 189-224, 291-329.

Horsley, Richard A., "Who Were the Witches? The Social Roles of the Accused in the European Witch Trials", Journal of Interdisciplinary History, 9 (1979), 689-715.

Hsia, R. Po-Chia,

The Myth of Ritual Murder: Jews and Magic in Reformation Germany, New Haven, 1988.

Huizinga, Johan,

The Waning of the Middle Ages: A Study of the Forms of Life, Thought and Art in France and the Netherlands in the XIVth and XVth Centuries, London, 1976.

Jerouschek, Günther,

"500 Jahre Hexenhammer - Das Buch, die Frau, der Prozeß: Der Malleus Maleficarum und seine Bedeutung als literarische Grundlage der Hexenverfolgungen zu Beginn der Neuzeit", Unpubl. Manuscript, Hannover, 1987.

Jerouschek, Günther,

"Der 'Nürnberger Hexenhammer' Heinrich Kramers", Unpubl. Manuscript, Hannover, 1990. 
Jones, William R.,

"Political Uses of Sorcery in Medieval Europe", The Historian: A Journal of Históy, 34 (1971-2), 670-87.

Kamen, Henry,

The Spanish Inquisition, London, 1965.

Karlsen, Carol F.

The Devil in the Shape of a Woman: Witchcraft in Colonial New England, New York, 1987.

Kephart M.J.,

"Rationalists vs. Romantics Among Scholars of Witchcraft", in: Witchcraft and Sorcery: Selected Readings, ed. by Max Marwick, 2nd. edn., Harmondsworth, 1982, 326-42.

Keussen, Hermann,

Die Matrikel der Universität Köln, Vol. 1, 1389-1475 (Publikation der Gesellschaft für Rheinische Geschichtskunde, 8), Bonn, 1928.

Keussen, Hermann,

"Regesten und Auszüge zur Geschichte der Universität Köln 1388-1559",

Mittheilungen aus dem Stadtarchiv von Köln, Vol. 15, Köln, 1918, 1-546.

Kieckhefer, Richard,

European Witch Trials: Their Foundations in Popular and Learned Culture, 1300-1500, London, 1976.

Kieckhefer, Richard,

The Repression of Heresy in Medieval Germany, Liverpool, 1979.

Kießling, Rolf,

Bürgerliche Gesellschaft und Kirche in Augsburg im Spätmittelalter: Ein

Beitrag zur Strukturanalyse der Oberdeutschen Reichsstadt (Abhandlungen zur Geschichte der Stadt Augsburg, 19), Augsburg, 1971.

Kittredge, George Lyman,

Witchcraft in Old an New England, Cambridge/Mass., 1929.

Klaniczy, G.,

"Shamanistic Elements in Central European Witchcraft", in: Shamanism

in Eurasia, Part Two, ed. by Mihaly Hoppal, Göttingen, 1984, 404-22. 
Klélé, J.,

Hexenwahn und Hexenprozesse in der ehemaligen Reichstadt und Landvogtei Hagenau, Hagenau, 1893.

Klose, Hans-Christian,

"Die angebliche Mitarbeit des Dominkaners Jakob Sprenger am Hexenhammer nach einem alten Abdinghofer Brief", in: Paderborniensis Ecclesia, Beiträge zur Geschichte des Erzbistums Paderborn: Festschrift für Lorenz Kardinal Jaeger, ed. by Paul-Werner Scheele, Paderborn, 1972, 197-205.

Knowles, David,

The Evolution of Medieval Thought, New York, 1962.

Koeniger, Albert,

Ein Inquisitionsprozess in Sachen der Täglichen Kommunion, Augsburg, 1923.

Krafft, K. and Wilhelm,

Briefe und Dokumente aus der Zeit der Reformation im 16. Jahrhundert nebst Mittheilungen über Kölnische Gelehrte und Studien im 13. und 16. Jahrhundert, Elberfeld, 1876.

Kunstmann, Hartmut H.,

Zauberwahn und Hexenprozess in der Reichsstadt Nürnberg

(Schriftenreihe des Stadtarchivs Nürnberg, 1), Nürnberg, 1970.

Kuttner, Stephan,

"The Revival of Jurisprudence", in: Renaissance and Renewal in the Twelfth Century, ed. by Robert L. Benson and Giles Constable, Oxford, 1985, 299-323.

von Laer, Annette,

"Die Spätmittelalterlichen Hexenprozesse in Konstanz und Umgebung", Schriften des Vereins für Geschichte des Bodensees und seiner Umgebung, 106 (1988), 13-27.

Lambert, M.D.,

Medieval Heresy: Popular Movements from Bogomil to Hus, London, 1977. 
Larner, Christina,

Enemies of God: The Witch-Hunt in Scotland, London, 1981.

Lea, Henry Charles,

A History of the Inquisition in the Middle Ages, 3 vols., New York, 1906.

Lea, Henry Charles,

Materials Toward a History of Witchcraft, Vol. 1, ed. by A.C. Howland, Philadelphia, 1939.

Leach, Edmund,

Social Anthropology, Glasgow, 1982.

Leist, Friedrich,

Die Notariats-Signete: Ein Beitrag zur Geschichte des Notariates, Leipzig, 1896.

Lerner, Robert E.,

The Heresy of the Free Spirit in the Later Middle Ages, Berkeley, 1972.

Levack, Brian P.,

The Witch-Hunt in Early Modern Europe, London, 1987.

Lewis, I.M.,

Ecstatic Religion: A Study of Shamanism and Spirit Possession, 2nd. edn., London, 1989.

Lloyd, G.E.R.,

Polarity and Analogy: Two Types of Argumentation in Early Greek Thought, Bristol, 1987.

Macfarlane, Alan, Witchcraft in Tudor and Stuart England: A Regional and Comparative Stiudy, London, 1970.

Macfarlane, Alan,

"Witchcraft in Tudor and Stuart Essex", in: Witchcraft Confessions \& Accusations, ed. by Mary Douglas, London, 1970, 81-99.

Machilek, Franz,

"Böhmische Brüder (Böhmische Brüderunität)", in: Theologische Realenzyklopädie, 7 (1981), 1-8. 
Maclean, Ian,

The Renaissance Notion of Woman: A Study in the Fortunes of Scholasticism and Medical Science in European Intellectual Life, Cambridge, 1985.

McNeill, John T.,

"Folk-Paganism in the Penitentials", The Journal of Religion, 13 (1933), 450-66.

Merchant, Carolyn,

The Death of Nature: Women, Ecology, and the Scientific Revolution, San Francisco, 1980.

Middletown, John and G.H. Winter, (eds.),

"Introduction", in: Witchcraft and Sorcery in East Africa, London, 1978, 1-26.

Midelfort, H.C. Erik,

"Witch-hunting and the Domino Theory", in: Religion and the People: 8001700, ed. by James Obelkevich, Chapel Hill, 1979, 277-90.

Midelfort, H.C. Erik, Witch Hunting in Southwestern Germany 1562-1684: The Social and Intellectual Foundations, Stanford, 1972.

Moi, Toril,

Sexual/Textual Politics: Feminist Literary Theory, London, 1987.

Monter, William E.,

"Law, Medicine, and the Acceptance of Witchcraft 1560-1580", in: European Witchcraft, ed. by E.W. Monter, New York, 1969.

Monter, William E.,

"The Pedestal and the Stake: Courtly Love and Witchcraft", in: Becoming Visible: Women in European History, ed. by Renate Bridenthal and Claudia Konz, Boston, 1977, 121-36.

Moore, R.I.,

The Birth of Popular Heresy, London, 1975.

Moore, R.I.,

The Formation of a Persecuting Society: Power and Deviance in Western 
Europe 950-1250, London, 1987.

Moore, R.I.,

The Origins of European Dissent, Oxford, 1985.

Moore, R.I.,

"The Origins of Medieval Heresy", History, 55 (1970), 21-36.

Morris, Colin,

The Discovery of the Individual 1050-1200 (Medieval Academy Reprints for Teaching, 19), Toronto, 1987.

Muchembled, Robert,

"The Witches of the Cambrésis: The Acculturation of the Rural World in the Sixteenth and Seventeenth Centuries", in: Religion and the People, 800-1700, ed. by James Obelkevich, Chapel Hill, 1979, 221-76.

Müller, Karl Otto,

"Heinrich Institoris, der Verfasser des Hexenhammers, und seine Tätigkeit als Hexeninquisitor in Ravensburg im Herbst 1484", Württembergische Vierteljahrshefte für Landesgeschichte, new ser., 19 (1910), 397-417.

Murray, Alexander,

"Medieval Origins of the Witch Hunt", The Cambridge Quarterly, 7 (1976), 63-74.

Murray, Alexander,

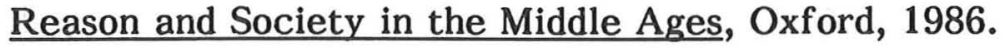

Nelson, Janet L.,

"Society, Theodicy and the Origins of Heresy: Towards a Reassessment of the Medieval Evidence", in: Schism, Heresy and Religious Protest: Studies in Church History, Vol. 9, ed. by Derek Baker, Cambridge, 1972.

Nicholson, Linda J. (ed.),

Feminism/Postmodernism, New York, 1990.

Oberman, Heiko,

The Dawn of the Reformation: Essays in Late Medieval and Early

Reformation Thought, Edinburgh, 1986. 
Partner, Peter, The Murdered Magicians: The Templars and their Myth, Oxford, 1982.

Pauls, Emil,

"Zauberwesen und Hexenwahn am Niederrhein", Beiträge zur Geschichte des Niederrheins: Jahrbuch des Düsseldorfer Geschichts-Vereins, 13 (1898), 134-242.

Paulus, N.,

"Ist die Kölner Approbation des Hexenhammers eine Fälschung?", Historisches Jahrbuch, 28 (1907), 871-76.

Paulus, N.,

"Zur Kontroverse über den Hexenhammer", Historisches Jahrbuch, 29 (1908), 559-74.

Peters, Edward, The Magician, the Witch and the Law, Brighton, 1978.

Peters, Edward,

Torture, Oxford, 1985.

Petersohn, Jürgen,

"Konziliaristen und Hexen: Ein unbekannter Brief des Inquisitors Heinrich Institoris an Papst Sixtus IV. aus dem Jahre 1484", Deutsches Archiv, 44 (1988), 120-60.

Petersohn, Jürgen,

"Zum Personalakt eines Kirchenrebellen: Name, Herkunft und Amtssprengel des Basler Konzilsinitiators Andres Jamometic", Zeitschrift für historische Forschung, 13 (1986), 1-14.

Pitz, Ernst,

"Diplomatische Studien zu den Päpstlichen Erlassen über das Zauber- und Hexenwesen", in: Der Hexenhammer: Entstehung und Umfeld des Malleus Maleficarum von 1487, ed. by Peter Segl, (Bayreuther Historische Kolloquien, 2), Köln, 1988, 23-69.

Prantl, Carl,

Geschichte der Logik im Abendlande, Vol. 4, Leipzig, 1870. 
Pullan, Brian,

The Jews of Europe and the Inquisition of Venice, 1550-1670, London, 1983.

Quétif-Echard,

Scriptores ordinis praedicatorum recensiti, notisque historicis et criticis illustrati. Inchoavit J. Quétif, absolvit I. Echard, 2 vols., Lutetiae Parisiorum, 1719-21.

Raeff, Marc,

The Well-ordered Police State: Social and Institutional Change Through Law in the Germanies and Russia, 1600-1800, New Haven, 1983.

Rajchman, John,

Michel Foucault: The Freedom of Philosophy, New York, 1985.

Ranke,

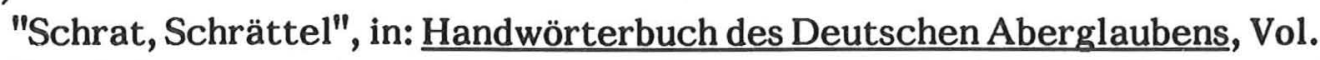
7, ed. by E. Hoffman-Krayer and Hanns Bächtold-Stäubli, Berlin and Leipzig, 1935-6, 1285-90.

Rapp, Ludwig,

Die Hexenprozesse und ihre Gegner in Tirol: Ein Beitrag von Kulturgeschichte, Innsbruck, 1874.

Rattansi, Pyarally Mohammed,

"Alchemy and Natural Magic in Raleigh's History of the World", Ambix, 13 (1966), 122-38.

Richards, Peter,

The Medieval Leper and His Northern Heirs, Cambridge, 1977.

von Riezler, Sigmund, (ed.),

Fürstenbergisches Urkundenbuch, Vol. 4, Tübingen, 1879.

von Riezler, Sigmund,

Geschichte der Hexenprozesse in Bayern, im Lichte der allgemeinen Entwicklung dargestellt, Stuttgart, 1896.

Robbins, Russell Hope,

The Encyclopedia of Witchcraft and Demonology, New York, 1981. 
Robert, John M.,

"Belief in the Evil Eye in World Perspective", in: The Evil Eye, ed. by Clarence Maloney, New York, 1976, 223-78.

Roos, Keith L.,

The Devil in 16th-century German Literature: the Teufelsbücher (European University Papers, ser. I, German Language and Literature, 68), Bern and Frankfurt, 1972.

Rothkrug, Lionel,

"Icon and Ideology in Religion and Rebellion 1300-1600: Bauernfreiheit and religion royale", in: Religion and Rural Revolt, ed. by Janos M. Buk and Gerhard Benecke, Manchester, 1984, 31-61.

Runciman, Steven,

The Medieval Manichee: A Study of the Christian Dualist Heresy, Cambridge, 1984.

Russell, Jeffrey Burton,

The Devil: Perceptions of Evil from Antiquity to Primitive Christianity, Ithaca, 1982.

Russell, Jeffrey Burton,

Lucifer: The Devil in the Middle Ages, Ithaca, 1984.

Russell, Jeffrey Burton,

Satan: The Early Christian Tradition, Ithaca, 1981.

Russell, Jeffrey Burton,

Witchcraft in the Middle Ages, Ithaca, 1972.

"Saligen, seligen", in:

Mittelniederdeutsches Handwörterbuch, Vol. 3, ed. by Gerhard Cordes, Neumünster, 1959, 16.

Schieler, K.,

Magister Johannes Nider, Mainz, 1885.

Schlecht, Joseph,

Andrea Zamometic und der Basler Konzilsversuch vom Jahre 1482, Vol.

1, (Quellen und Forschungen aus dem Gebiete der Geschichte in Verbindung mit ihrem Historischen Institut in Rom, 8) Paderborn, 1903. 
Schnyder, André,

"Der Malleus Maleficarum: Unvorgreifliche Überlegungen und Beobachtungen zum Problem der Textformen", in: Der Hexenhammer: Entstehung und Umfeld des 'Malleus Maleficarum' von 1487, ed. by Peter Segl, Köln, 1988, 127-49.

Schnyder, André und Franz Worstbrock,

"Institoris, Heinrich OP", in: Die Deutsche Literatur des Mittelalters:

Verfasserlexikon, 2nd edn., ed. by Kurt Ruh, Vol. 4, 1983, 407-15.

Schwarzwälder, Herbert,

"Die Formen des Zauber- und Hexenglaubens in Bremen und seiner weiteren Umgebung, vor allem während des 16. und 17. Jahrhunderts", in: Heimat und Volkstum: Bremer Beiträge zur Niederdeutschen Volkskunde (1958), 3-68.

Schweizer, Paul,

"Der Hexenprozess und seine Anwendung in Zürich", Zürcher Taschenbuch, new ser., 25 (1902), 1-63.

Schwerhoff, Gerd,

"Rationalität im Wahn: Zum gelehrten Diskurs über die Hexen in der frühen Neuzeit", Saeculum, 37 (1986), 45-82.

Sedgwick, Peter,

Psycho-Politics, London, 1982.

Segl, Peter,

"Heinrich Institoris. Persönlichkeit und literarisches Werk", in: Der Hexenhammer: Entstehung und Umfeld des Malleus Maleficarum von 1487, ed. by Peter Segl (Bayreuther Historische Kolloquien, 2), Köln, 1988, 103-26.

Segl, Peter, (ed.),

Der Hexenhammer: Entstehung und Umfeld des Malleus Maleficarum von 1487 (Bayreuther Historische Kolloquien, 2), Köln, 1988.

Senn, Harry A.,

Were-wolf and Vampire in Rumania, New York, 1982.

Smalley, Beryl,

"William of Auvergne, John of La Rochelle and St. Thomas Aquinas on 
the Old Law", in: St. Thomas Aquinas 1274-1974: Commemorative Studies, ed. by the Pontifical Institute of Medieval Studies, Toronto, 1974, 11-71.

Soldan, W.G. and H. Heppe,

Geschichte der Hexenprozesse, ed. by Max Bauer, 2 vols., Hanau, without date.

Sontag, Susan,

Illness as Metaphor, Harmondsworth, 1978.

Stallybrass, Peter, and Allan White,

The Politics and Poetics of Transgression, London, 1986.

Stock, Brian,

The Implications of Literacy: Written Language and Models of Interpretation in the Eleventh and Twelf th Centuries, Princeton, 1983.

Strauss, Gerald,

Law, Resistance, and the State: The Opposition to Roman Law in

Reformation Germany, Princeton, 1986.

Szasz, Thomas,

The Manufacture of Madness: A Comparative Study of the Inquisition and the Mental Health Movement, London, 1971.

Thomas, Keith,

"The Relevance of Social Anthropology to the Historical Study of English Witchcraft", in: Witchcraft Confessions \& Accusations, ed. by Mary Douglas, London, 1970, 47-79.

Thomas, Keith,

Religion and the Decline of Magic: Studies in Popular Beliefs in Sixteenth- and Seventeenth-Century England, Harmonswort, 1982.

Thorndike, Lynn,

A History of Magic and Experimental Science, Vol. 4, New York, 1934.

Tobler, G.,

"Zum Hexenwesen in Bern", Schweizerisches Archiv für Volkskunde, 2 (1898), 59-60; and 4 (1900), 236-8. 
Trachtenberg, Joshua,

The Devil and the Jews: The Medieval Conception of the Jew and Its

Relation to Modern Antisemitism, Philadelphia, 1961.

Trevor-Roper, Hugh R.,

The European Witch-Craze of the 16th and 17th Centuries,

Harmondsworth, 1984.

Vickers, Brian,

"Analogy versus Identity: the Rejection of Occult Symbolism 1580-1680", in: Occult and Scientific Mentalities in the Renaissance, ed. by Brian Vickers, Cambridge, 1986, 96-163.

Vickers, Brian,

"On the Function of Analogy in the Occult", in: Hermeticism and the Renaissance: Intellectual History and the Occult in Early Modern Europe, ed. by Ingrid Merkel and Allen G. Debus, London, 1983, 266-92.

Voullième, Ernst,

Der Buchdruck Kölns bis zum Ende des 15. Jahrhunderts, Bonn, 1903.

von Waechter, Karl Georg,

Beiträge zur Deutschen Geschichte, insbesondere zur Geschichte des Deutschen Strafrechts, Tübingen, 1845.

Wakefield, Walter L. and Austin P. Evans,

Heresies of the High Middle Ages (Records of Civilization Sources and Studies, 81), New York, 1969.

Walker, D.P.,

Spiritual and Demonic Magic, Notre Dame, 1975.

Weedon, Chris,

Feminist Practice and Poststructuralist Theory, Oxford, 1987.

Weiser-Aall,

"Hexe", in: Handwörterbuch des Deutschen Aberglaubens, Vol. 3, ed. by E. Hoffmann-Krayer and Hanns Bächtold-Stäubli, Berlin and Leipzig, 1930-1, 1827-1919.

Wetzer und Welte,

Kirchenlexikon oder Encyclopädie der Katholischen Theologie und ihrer 
Hilfswissenschaften, 2nd edn. Vol. 6, Freiburg im Breisgau, 1889.

Wibel, $\mathrm{H}$.

"Neues zu Heinrich Institoris", Mittheilungen des Instituts für Österreichische Geschichtsforschung, 34 (1913), 121-5.

Yates, Frances A.,

Giordano Bruno and the Hermetic Tradition, London, 1964.

Yates, Frances A.,

"The Hermetic Tradition in Renaissance Science", in: Art, Science, and History in the Renaissance, ed. by Charles S. Singleton, Baltimore, 1968.

Zambelli, Paola,

"Scholastic and Humanist Views of Hermeticism and Witchcraft", in: Hermeticism and the Renaissance: Intellectual History and the Occult in Early Modern Europe, London, 1988, 125-53.

Ziegeler, Wolfgang,

Möglichkeiten der Kritik am Hexen- und Zauberwesen im Ausgehenden Mittelalter: Zeitgenössische Stimmen und ihre Soziale Zugehörigkeit, Wien 1973.

Zika, Charles,

"Hosts, Processions and Pilgrimages: Controlling the Sacred in FifteenthCentury Germany", Past and Present, 118 (1988), 24-64.

Zika, Charles,

"Reuchlin's De Verbo Mirifico and the Magic Debate of the Late Fifteenth Century", Journal of the Warburg and Courtauld Institutes, 39 (1976), 104-38.

\section{Zilboorg, Gregory,}

The Medical Man and the Witch During the Renaissance (Publications of the Institute of the History of Medicine of the John Hopkins University, third ser., Vol. 2), Baltimore, 1935.

Zimmermann, Wolfgang,

"Teufelsglaube und Hexenverfolgungen in Konstanz 1546-1548", Schriften des Vereins für Geschichte des Bodensees und seiner Umgebung, 106 (1988), 29-57. 
Zoepfl, Friedrich,

Das Bistum Augsburg und seine Bischöfe im Mittelalter, Vol. 1, Augsburg, 1955.

\section{Unpublished Dissertations.}

Bever, Edward,

"Witchcraft in Early Modern Württemberg", Princeton, 1983.

Hopkin, Charles Edward,

"The Share of Thomas Aquinas in the Growth of the Witchcraft Delusion", Pennsylvania, 1940.

[A copy of this dissertation is held at the University Library of Cambridge - Catalogue no. 45.41.c.90.108.] 